University of Louisville ThinkIR: The University of Louisville's Institutional Repository

Electronic Theses and Dissertations

$8-2016$

\title{
Effects of invasive shrub honeysuckle (Lonicera maackii) and forest composition on bird communities in woodland stands.
}

Katie Rae Lynch

University of Louisville

Follow this and additional works at: https://ir.library.louisville.edu/etd

Part of the Biodiversity Commons, and the Other Ecology and Evolutionary Biology Commons

\section{Recommended Citation}

Lynch, Katie Rae, "Effects of invasive shrub honeysuckle (Lonicera maackii) and forest composition on bird communities in woodland stands." (2016). Electronic Theses and Dissertations. Paper 2518.

https://doi.org/10.18297/etd/2518

This Doctoral Dissertation is brought to you for free and open access by ThinkIR: The University of Louisville's Institutional Repository. It has been accepted for inclusion in Electronic Theses and Dissertations by an authorized administrator of ThinkIR: The University of Louisville's Institutional Repository. This title appears here courtesy of the author, who has retained all other copyrights. For more information, please contact thinkir@louisville.edu. 
EFFECTS OF INVASIVE SHRUB HONEYSUCKLE (LONICERA MAACKII) AND FOREST COMPOSITION ON BIRD COMMUNITIES IN WOODLAND STANDS

\author{
By \\ Katie Rae Lynch \\ B.S., University of Kentucky—Lexington, 2008 \\ M.S., University of Louisville, 2016
}

\author{
A Dissertation \\ Submitted to the Faculty of the \\ College of Arts and Sciences \\ of the University of Louisville \\ in Partial Fulfillment of the Requirements \\ for the Degree of
}

Doctor of Philosophy in Biology

Department of Biology

University of Louisville

Louisville, Kentucky

August 2016 

EFFECTS OF INVASIVE SHRUB HONEYSUCKLE (LONICERA MAACKII) AND FOREST COMPOSITION ON BIRD COMMUNITIES IN WOODLAND STANDS

\author{
By \\ Katie Rae Lynch \\ B.S., University of Kentucky, 2008 \\ M.S., University of Louisville, 2016 \\ A Dissertation Approved on
}

July 18, 2016

By the following Dissertation Committee:

Dr. James Alexander

Dr. Margaret Carreiro

Dr. Gary Cobbs

Dr. Perri Eason

Dr. Lindsey Walters 


\section{ACKNOWLEDGEMENTS}

I would like to thank my committee members, Dr. James Alexander, Dr. Lindsey Walters (Northern Kentucky University), Dr. Gary Cobbs, Dr. Margaret Carreiro, and Dr. Perri Eason for their help and guidance throughout my graduate studies and the completion of my dissertation.

Help with extensive field work was provided by Dr. James Alexander, Victoria Prescott, and Julio Wilson. Organizations that provided funding for my research were the Horner Preserve Fund, Graduate Student Union and Graduate Student Council at the University of Louisville. I would like to give a special thanks to Dr. Gary Cobbs for helping me to navigate SAS. Lastly, I would like to thank my friends and family for their love and support through this process. 


\begin{abstract}
EFFECTS OF INVASIVE SHUB HONEYSUCKLE (LONICERA MAACKII) AND FOREST COMPOSITION ON BIRD COMMUNITIES IN WOODLAND STANDS
\end{abstract}

\author{
Katie R. Lynch
}

July 18, 2016

Invasive species pose a threat to aquatic and terrestrial ecosystems by decreasing biodiversity (Didham et al. 2005). The mechanism by which invasive species negatively impact environments is typically through either the direct effect of increased dominance or the indirect effect of territory modification. Invasive plant species have the potential to affect both other flora and fauna when grown out of cultivation. Amur bush honeysuckle (Lonicera maackii) was brought to the United States from northeast Asia in 1898 as an ornamental plant intended for land restoration and to provide habitat for birds (Luken and Thieret 1996). The woody shrub has since escaped cultivation and is currently considered invasive in 27 states according to the USDA. Its early leaf phenology, production of copious red berries, allelopathic effects, and morphological plasticity provide Amur honeysuckle with a competitive advantage over native plants (Ingold and Craycraft 1983; Luken and Thieret 1996; McEwan et al. 2010).

Amur honeysuckle has typically reduced native plant diversity and altered animal communities [annelids, arthropods, herptile, small mammals, and birds] by influencing animal abundance and activity (Collier and Vankat 2002; Loomis and Cameron 
2013; McCuster et al. 2010; McEvoy and Durtsche 2004; Pipal 2014). This study was intended to determine whether honeysuckle density or other compositional characteristics of forested stands influence avian diversity, whether impacts are seasonally dependent, and whether correlations exist between attributes of forested stands and honeysuckle density. Specific hypotheses include: 1a) honeysuckle density will negatively impact bird diversity in all seasons due to changes in bird evenness; 1b) changes in bird diversity due to compositional features of the forest stands, specifically a positive correlation between bird diversity and the forest stand characteristics of canopy cover and mean tree height; 2a) fluctuations in bird diversity based upon honeysuckle density will occur due to increased abundance of understory bird species [Northern cardinals, sparrows, and thrushes] particularly during the breeding season [spring and summer] and decreased abundance of mid and upper canopy bird species [Eastern wood-pewees and other flycatchers, parids, warblers, and woodpeckers]; 2b) changes in avian diversity will also be due to increased abundance of facultative frugivores [American robins] in the fall; 3a) tree diversity, percent canopy cover, and mean tree height of forest stands will negatively correlate with honeysuckle density because of the life history traits of honeysuckle; $3 b$ ) the extent of anthropogenic influence will positively correlate with honeysuckle density because of the potential affinity of honeysuckle for more disturbed, urbanized habitats.

In order to test the hypotheses, thirteen forest stands within the Louisville Metropolitan Area were selected. They had similar tree composition but varied in density of honeysuckle [six forest stands with Lonicera maackii present and seven stands with little to no honeysuckle]. Vegetation surveys and an assessment of anthropogenic impact were conducted at all stands. Bird surveys were performed at each stand once every 
season for two years by walking a one-kilometer trail and identifying birds visually and acoustically within 20 meters of either side of the trail. Multiple regression analyses using PROC MIXED of SAS examined the effects of honeysuckle density, tree diversity, mean tree height, percent canopy cover, and extent of anthropogenic influence on bird diversity (Goodnight 2015). Honeysuckle density $(\mathrm{p}=0.0208)$ and anthropogenic influence $(\mathrm{p}=$ 0.0439) significantly negatively impacted bird diversity but these effects did not significantly vary seasonally. Urbanized forest stands cannot support a wide variety of bird species but rather only species adapted to urban conditions. As predicted, bird diversity had a positive correlation with percent canopy cover and mean tree height. However, these effects were not significant.

Nonmetric multidimensional scaling (NMDS) ordination was used to quantify compositional aspects of forest stands into axis values to visualize the effects of honeysuckle density on bird species and families. Effects of the representative values of compositional components (axes) and honeysuckle density on abundance of the most abundant birds observed during the study and on bird families were analyzed using generalized Poisson regression for every season in both study years (PROC GLIMMIX, Goodnight 2015). Abundance of sparrows and cardinals were positively associated with honeysuckle density during the breeding season of both years and significantly in the summer of year 2 for cardinals $(\mathrm{p}=0.0015)$. Honeysuckle density had varied impacts on thrush abundance but did positively influence abundance significantly in the fall of both years (year $1 \mathrm{p}=0.0034$; year $2 \mathrm{p}=0.0028$ ). This significant impact was due to the positive association of honeysuckle density with the most abundant thrush species, the American robin, in the fall of both years. Commonly observed mid-canopy species that 
were negatively impacted by honeysuckle density in most seasons were the tufted titmouse and white-breasted nuthatch. The Eastern wood-peewee, an upper canopy species, was observed half as often in areas with relatively high densities of honeysuckle compared to areas with low densities. Seasonal dominance of some birds [cardinals and sparrows in the spring and summer and thrushes in the fall] in habitat invaded by honeysuckle causes an overall decrease in avian diversity.

To determine whether any correlations existed between honeysuckle density and compositional components of the forest stands, PROC CORR of SAS was used (Goodnight 2015). Mean tree height was the only forest stand characteristic that had a significantly negative relationship with honeysuckle density $(\mathrm{p}=<0.0001)$. The dense shrub layer in forest stands with relatively high honeysuckle density reduced the overall height of the stands, and habitats with large, old growth trees are often more resistant to honeysuckle invasion (Hutchinson and Vankat 1997). Tree diversity and percent canopy cover negatively correlated with honeysuckle density whereas degree of anthropogenic influence positively correlated with honeysuckle density as anticipated. None of these effects were significant, however.

Results of the study demonstrate that the two major determinants of avian diversity in forest stands of the southeast US (Louisville metropolitan area) were honeysuckle density and magnitude of anthropogenic influence. My study reveals how a pervasive shrub can reduce bird diversity through the seasonal dominance of some species preferring habitats of dense honeysuckle [cardinals, sparrows, and thrushes] and a slight decrease in abundance of some canopy species [titmice, nuthatches, and Eastern 
wood-pewees]. Land managers should be aware of the potential honeysuckle has to decrease bird diversity, especially if left unmanaged. 


\section{TABLE OF CONTENTS}

\section{PAGE}

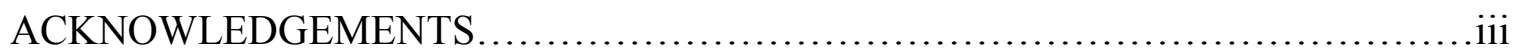

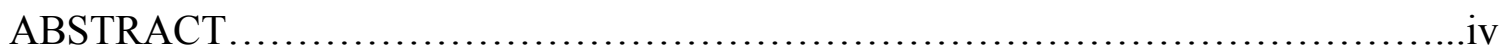

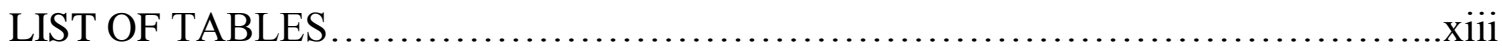

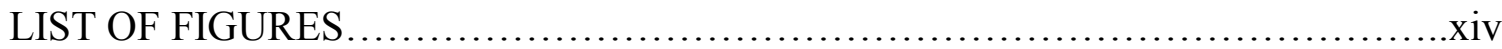

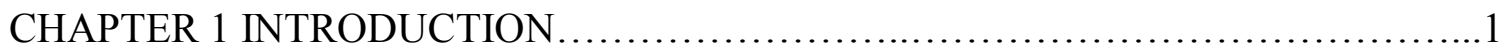

Amur honeysuckle: an important invasive species in North America..............1

Amur honeysuckle characteristics........................................

Mechanisms of invasion for Amur honeysuckle.................................

Amur honeysuckle effects on plants and community function...................

Amur honeysuckle effects on local fauna...................................11

Forest composition and surrounding matrix effects on birds...................15

Previous studies examining the impact of honeysuckle on birds..................18

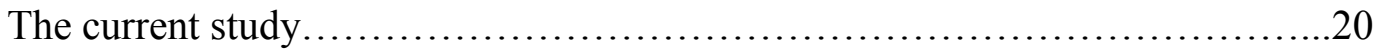

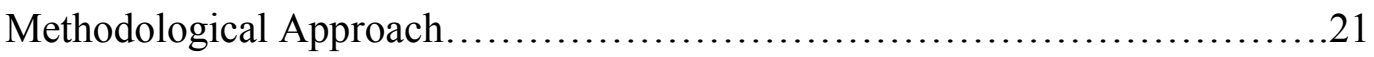

Question 1: How do bush honeysuckle and characteristics of forest stands affect

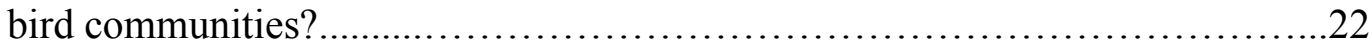

Question 2: What underlying mechanisms are causing fluctuations in avian diversity due to Amur honeysuckle (if fluctuations in bird diversity occurred)?..23

Question 3: Are there correlations between honeysuckle density and characteristics of forest stands? ..........................................24

CHAPTER 2: DESCRIPTION OF STUDY SITES .................................. 
Blackacre State Nature Preserve and Historic Homestead...................... 30

Cherokee Park........................................................ 30

Charlestown State Park................................................... 32

Horner Nature Preserve.................................................. 32

Iroquois Park...................................................... 33

Joe Creason Park.................................................... 34

Jefferson Memorial Forest.................................................. 34

Lapping Park ..................................................... 35

McNeely Lake Park.................................................. 36

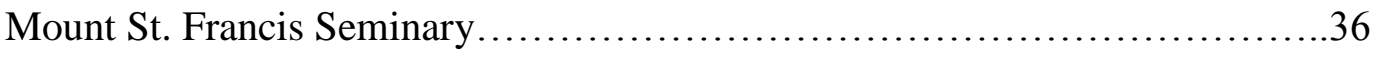

E.P. 'Tom' Sawyer State Park............................................... 37

CHAPTER 3: STUDY METHODS ......................................... 38

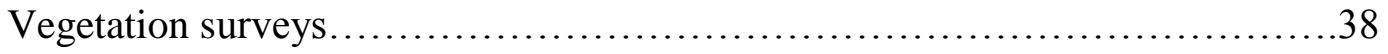

Estimation of anthropogenic impacts..................................... 39

Bird surveys....................................................41

CHAPTER 4: FOREST STAND COMPOSITION $\ldots \ldots \ldots \ldots \ldots \ldots \ldots \ldots \ldots \ldots \ldots \ldots \ldots . \ldots . \ldots \ldots$

Statistical Analysis................................................43

Results...........................................................44

Blackacre State Nature Preserve and Historic Homestead....................47

Cherokee Park........................................................48

Charlestown State Park...............................................48

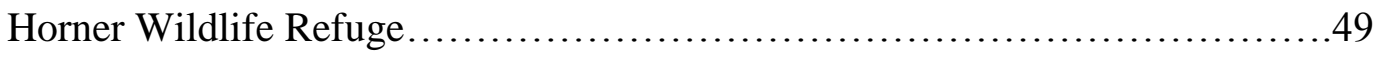

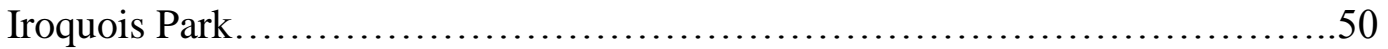


Joe Creason Park.............................................................50

Jefferson Memorial Forest...............................................51

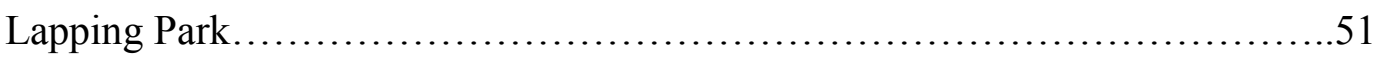

McNeely Lake Park ............................................................

Mount St. Francis Seminary .............................................. 52

E.P. ‘Tom' Sawyer State Park.............................................52

CHAPTER 5: OVERALL IMPACT OF HONEYSUCKLE AND FOREST STAND CHARACTERISTICS ON OVERALL BIRD DIVERSITY.............................54

Statistical Analysis......................................................54

Results.............................................................. 56

CHAPTER 6: IMPACT OF HONEYSUCKLE ON SPECIFIC BIRD TAXA............63

Statistical Analysis.....................................................63

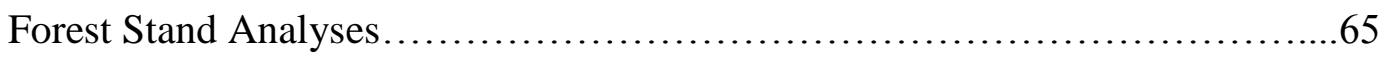

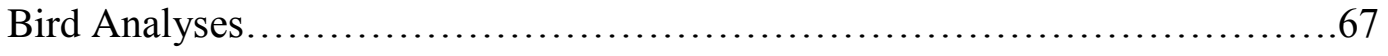

Results for Specific Species.............................................69

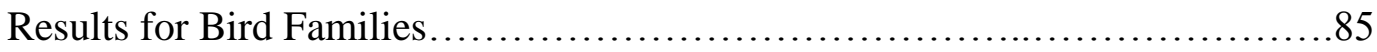

CHAPTER 7: CORRELATIONS BETWEEN HONEYSUCKLE AND OTHER

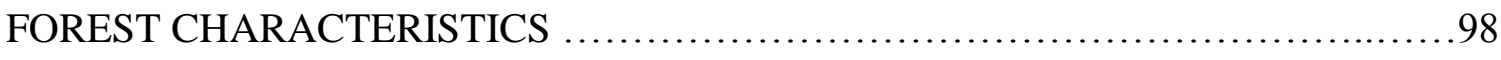

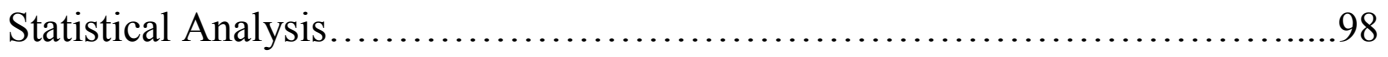

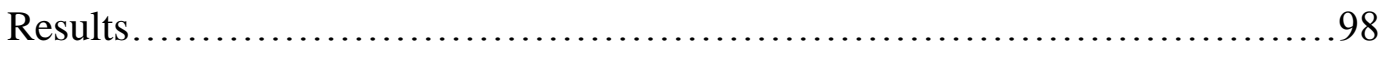

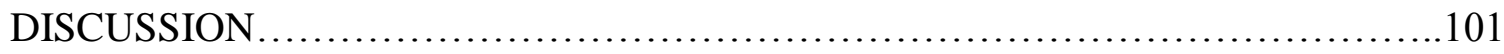

Effects of honeysuckle on bird diversity ................................... 101

Mechanisms responsible for changes in avian diversity due to honeysuckle.....105

Effects of other forest variables on bird diversity.......................... 114 
Correlations between honeysuckle and characteristics of forest stands....

Summary.......................................................121

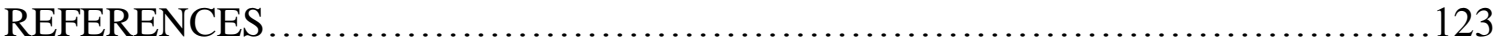

APPENDICES...........................................................131

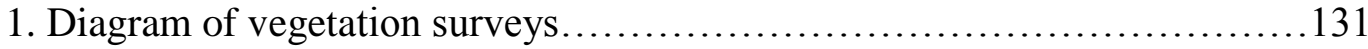

2. Information from the vegetation surveys..............................133

3. Alpha diversity results of bird surveys............................... 136

4. Results of the multiple regression analyses............................144

5. Proportion of 43 tree genera........................................ 145

6. Attributes of the 13 forest stands...................................... 152

7. Three axes values obtained from the NMDS analysis......................153

8. Parameter Estimates and Significance of Effects to Birds..................154

9. Effects of honeysuckle density..................................... 178

10. List of All Bird Species and Frequency Observed....................... 182

CURRICULUM VITAE..................................................... 185 


\section{LIST OF TABLES}

TABLE

PAGE

1. Information for the Thirteen Forest Stands.........................................45

2. Parameter Estimates and Significance of Effects to Northern Cardinals...............70

3. Parameter Estimates and Significance of Effects to American Robins................73

4. Parameter Estimates and Significance of Effects to Tufted Titmice...................76

5. Parameter Estimates and Significance of Effects to Carolina Chickadee................77

6. Parameter Estimates and Significance of Effects to Carolina Wrens....................79

7. Parameter Estimates and Significance of Effects to Blue Jays........................81

8. Parameter Estimates and Significance of Effects to White-breasted Nuthatches........84

9. Parameter Estimates and Significance of Effects to Thrushes..........................86

10. Parameter Estimates and Significance of Effects to Sparrows..................... 88

11. Parameter Estimates and Significance of Effects to Parids.........................92

12. Parameter Estimates and Significance of Effects to Woodpeckers....................94

13. Parameter Estimates and Significance of Effects to Warblers........................96 


\section{LIST OF FIGURES}

FIGURES

PAGE

1. Map of the Thirteen Forest Stand Locations.................................29

2. Relationship Between Honeysuckle Density and Bird Diversity....................58

3. Relationship Between Canopy Cover and Bird Diversity..........................59

4. Relationship Between Mean Tree Height and Bird Diversity......................60

5. Relationship Between Tree Stand Diversity and Bird Diversity $\ldots \ldots \ldots \ldots \ldots \ldots \ldots \ldots \ldots 61$

6. Relationship Between Anthropogenic Index and Bird Diversity...................62

7. 2-D Scatter Plot of the 13 Forest Stands....................................65

8. 3-D Depiction of Effects to Northern Cardinals............................... 71

9. 3-D Depiction of Effects to American Robins................................. 74

10. 3-D Depiction of Effects to Blue Jays.................................... 82

11. 3-D Depiction of Effects to Sparrow a. ..................................... 89

12. 3-D Depiction of Effects to Sparrow b. .................................. 90

13. Correlations of Honeysuckle Density and Forest Stand Characteristics............100 


\section{CHAPTER 1: INTRODUCTION}

\section{Amur honeysuckle: an important invasive species in North America}

The epic transformation of many landscapes by alien species was captured by the description of the 'Homogocene' era over 20 years ago (Didham et al. 2005). The era describes the phenomenon of an increase in the number of non-native species coinciding with the decrease in native species in habitats across the world. Non-native species are considered invasive species once they cause considerable damage to native biota, human development, or human health (Lodge et al. 2006; Mainka and Howard 2010). The Nature Conservancy estimates invasive plants affect approximately 100 million acres, and costs to control invasive species in the United States alone exceed $\$ 120$ billion per year (Tercek 2016). Invasive species often negatively impact aquatic and terrestrial ecosystems by decreasing biodiversity (Didham et al. 2005). Various theories have been developed to assess whether native species declines are due either to the direct effect of invasive species rise in dominance, such as displacement of native species, or to the indirect effect of environmental modification.

The Amur bush honeysuckle Lonicera maackii (Ruprecht, family Caprifoliaceae) is an invasive shrub brought to the United States as an ornamental plant in 1898 from northeast Asia (Luken and Thieret 1996). The shrub is now under threat in its native region of China, Korea, Japan, and southeastern Russia due to over-collection of leaves for medicinal uses (Lieurance and Cipollini 2011). The shrub was used by USDA Soil 
Conservation Service from the 1960s to the 1980s for land rejuvenation and to furnish bird habitat (Luken and Thieret 1996). Lonicera maackii is now considered an invasive species in 27 states and planting it is prohibited in Massachusetts according to the USDA. Its broad habitat tolerance, along with its abilities to germinate under varying light intensities and to reproduce vegetatively, have enabled L. maackii to flourish across many landscapes (Luken and Goessling 1995); Amur honeysuckle has become naturalized in at least 24 states east of the Rocky Mountains (Watling and Orrock 2010). Lonicera maackii occupies edge habitat, forest interior, riparian zones, and suburban neighborhoods indicating it can tolerate both mesic and hydric soil types (K.R. Lynch, personal observation; Luken and Goessling 1995; Luken and Thieret 1996). Other shrub species of Lonicera are considered invasive or are prohibited in many mid-eastern states; however, Lonicera maackii comprises the highest abundance of Lonicera within the study region. The other honeysuckle species occasionally encountered in the Louisville metropolitan area are Lonicera tatarica (Linnaeus), Lonicera morrowii (A. Gray), and Lonicera fragrantissima (Lindley and Paxton). One other common honeysuckle species, the Japanese honeysuckle, Lonicera japonica (Thunberg), is a vine that has created ecological problems and is on the federal noxious weed list in four states (Vilsack 2015).

\section{Amur honeysuckle characteristics}

Lonicera maackii is a deciduous woody shrub between two and six meters in height at maturity, with multiple upright tangling stems and a typically shallow root system (Deering and Vankat 1999). The shrub has an early leaf phenology producing 
green, lancelet-shaped leaves in early spring, well before the majority of native plants. Amur honeysuckle also retains its leaves late into fall (Luken and Thieret 1996). A study by Trammell et al. (2012) demonstrated foliar biomass of honeysuckle in a heavily invaded forest was much greater than that of native trees in the late fall whereas native foliar biomass was greater in early fall. The shrub is monoecious and produces white, tubular flowers in late spring; the flowers are pollinated by honey bees and moths. In the late summer, bright red spherical fruits are produced ranging from 3.5 to $8.5 \mathrm{~mm}$ in diameter with an average of 4.6 seeds per fruit (Bartuszevige and Gorchov 2006). Honeysuckle shrubs become sexually reproductive at five to eight years of age (Deering and Vankat 1999) and berry abundance can reach up to 1.2 million berries per bush on large shrubs; up to 400 million berries thus can be produced per hectare (Ingold and Craycraft 1983). Honeysuckle fruit is considered a poor energy source for frugivores, due to its high C:N ratio and low lipid content (Ingold and Craycraft 1983). However, the berries are so plentiful and conspicuous they attract a variety of animal dispersers, predominantly birds.

\section{Mechanisms of invasion for Amur honeysuckle}

Avian dispersal allows for long distance distribution of Amur honeysuckle, particularly to edge habitats. Many common North American bird species have been known to consume honeysuckle fruit (Bartuszevige and Gorchov 2006). These bird species are listed in the following: 


\begin{tabular}{|l|l|}
\hline \multicolumn{2}{|c|}{ Birds known to consume fruits of Lonicera maackii } \\
\hline American robin & Turdus migratorius Linnaeus \\
\hline American tree sparrow & Spizella arborea Wilson \\
\hline brown creeper & Certhia americana Bonaparte \\
\hline Carolina chickadee & Poecile carolinensis Audubon \\
\hline Carolina wren & Thryothorus ludovicianus Latham \\
\hline cedar waxwing & Bombycilla cedrorum Vieillot \\
\hline dark-eyed junco & Junco hyemalis Linnaeus \\
\hline downy woodpecker & Picoides pubescens Linnaeus \\
\hline Eastern bluebird & Sialia sialis Linnaeus \\
\hline European starling & Sturnus vulgaris Linnaeus \\
\hline gray catbird & Dumetella cardolinensis Linnaeus \\
\hline golden-crowned kinglet & Regulus satrapa Lichtenstein \\
\hline hermit thrush & Catharus guttatus Pallas \\
\hline Northern mockingbird & Mimus polyglottos Linnaeus \\
\hline Northern cardinal & Cardinalis cardinalis Linnaeus \\
\hline song sparrow & Melospiza melodia Wilson \\
\hline tufted titmouse & Baeolophus bicolor Linnaeus \\
\hline white-breasted nuthatch & Sitta carolinensis Wilson \\
\hline white-throated sparrow & Zonotrichia albicollis Gmelin \\
\hline
\end{tabular}

A study by Bartuszevige and Gorchov (2006) compared damage to honeysuckle seeds during gut passage through American robins and cedar waxwings; results of the study showed that of the two species tested, only the gut of robins did not cause considerable damage to honeysuckle seeds and viable seeds were defecated (Bartuszevige and Gorchov 2006). Robins are the main avian disperser of honeysuckle and typically occupy edge habitats (Ingold and Craycraft 1983). Because L. maackii is slightly shade intolerant, the combination of increased light availability and abundant seed dispersers allows for efficient distribution of honeysuckle in edge habitats (Luken and Thieret 1996). A study by Luken and Mattimiro (1997) demonstrated that Amur honeysuckle grown in open habitats was more resilient (here defined as the ability to rebound after a 
disturbance) to regimented clippings than honeysuckle shrubs in forests, based on measurements of their resprouting abilities. This resiliency is more than likely due to increased energy stores of open-grown shrubs, due to the higher light availability and lower competition for resources in the open habitat (Luke and Mattimiro 1997). Density of honeysuckle in invaded woodlots in an agricultural matrix of Ohio positively correlated with the amount of landscape edge (partial $\mathrm{R}^{2}=0.592$ ) (Bartuszevige et al. 2006).

The edge habitats that are common in fragmented forest stands allow diffusion of Amur honeysuckle into forest interiors. White-tailed deer (Odocoileus virginianus Zimmermann) are known to browse on L. maackii foliage and ingest fruit while doing so; viable seeds are voided by the deer, thus aiding in long distance dispersal of seeds and dispersal to the interior of forests (Castellano and Gorchov 2013). Mice (Peromyscus spp.) are also known to disperse honeysuckle seeds but shorter distances relative to deer (Castellano and Gorchov 2013). The susceptibility of a forest to honeysuckle invasion is dependent upon the forest's successional stage, the degree of urbanization, frequency of disturbances, distance from other invaded areas, and the composition of its shrub layer. Secondary forests in more urbanized and/or disturbed habitats are more susceptible to honeysuckle invasion than are late-successional, mature forests. A study by Hutchinson and Vankat (1997) examining the invasibility of forest communities by L. maackii in southwestern Ohio concluded that high light levels and proximity to a highly urbanized area corresponded with higher L. maackii cover. Explanatory variables inversely related to L. maackii cover were tree seedling density and species richness of seedlings (Hutchinson and Vankat 1997). In order of decreasing importance, honeysuckle cover 
was most explained by inverse relationships with tree canopy cover, distance from urban hub, shade tolerance index, and total tree basal area, and lastly by a positive relationship with time since invasion (Hutchinson and Vankat 1997). Old-growth forests appear to be more resistant (resistance here defined as the ability to resist large changes in species composition) to honeysuckle invasion. A study by Wilson et al. (2013) found a negative correlation between L. maackii density and both litter depth of the forest floor and percent of oak litter, suggesting a decreased risk of honeysuckle invasion into older forests, particularly those dominated by oak species.

The ‘enemy release hypothesis' (ERH, see Keane and Crawley 2002) has been suggested as a mechanism of honeysuckle invasion. ERH states that when introduced to a nonnative habitat, predators or consumers of a given introduced species will not be present, allowing the species to successfully establish in the new territory (Lieurance and Cipollini 2012). For invasive plant species, a lack of specialist herbivores or increased resistance to generalists is a mechanism of invasion. A study by Lieurance and Cipollini (2012) assessed herbivory to Amur honeysuckle shrubs in forest interior and edge habitats of central and southwestern Ohio. Results of the study showed that chewing by generalist herbivores was the most common type of damage to the shrubs. The most damage occurred to shrubs in the edge habitats (compared to those in the forest interior) and to longer shoots relative to shorter shoots (Lieurance and Cipollini 2012). All in all, outcomes of the study demonstrated that arthropod herbivory to honeysuckle was not prevalent enough to influence plant fitness. ERH also predicts that more damage by herbivores is typically done to native congeners than to nonnatives (Lieurance and Cipollini 2012). In a common garden experiment comparing herbivory rates to exotic 
shrub honeysuckle and grape honeysuckle (Lonicera reticulata Rafinesque, native to the mid-eastern US), there was substantially increased herbivory to native honeysuckle. This result is potentially a consequence of slight differences between the secondary compounds of native and exotic honeysuckle; native shrubs tended to produce more iridoid glycosides whereas nonnative plants produced more phenolic compounds. Phenolic compounds are a common defense against herbivory and iridoid glycosides a defense against ovipositors, such as some wasp species (Lieurance et al. 2015).

\section{Amur honeysuckle effects on plants and community function}

This vigorous exotic shrub has received a lot of attention from biologists and land managers in the last 20 years because of honeysuckle's detrimental effects on both floral and faunal composition within the invaded ecosystem. Once it has invaded a lowresistance forested area, Amur honeysuckle requires approximately 10 years to transform the forest understory into essentially a monoculture of L. maackii, due primarily to its morphological plasticity, high net primary production, and high energy allocation to fruit production (Hutchinson and Vankat 1997). Its gnarled stems adjust to the light availability of the environment as evidenced by shrub structure differences in open versus forest habitats, which are more vertically and horizontally oriented, respectively (Luken et al. 1995). Open-grown honeysuckle groves have been documented to reach net primary production values of $1350 \mathrm{~g} \cdot \mathrm{m}^{-2} \cdot \mathrm{yr}^{-1}$, rivaling that of entire woodlot communities (Whittaker 1975). 
The formation of vast monocultures of Amur honeysuckle has undoubtedly altered the landscape in which the shrubs have invaded. The dense understory blanket created by $L$. maackii outcompetes many native plant species, ultimately decreasing native species richness, abundance, and fitness. Gould and Gorchov (2000) demonstrated significantly lower fecundity and survivorship of three annual native herbs after a year in plots with bush honeysuckle, compared to plots where honeysuckle was absent or removed. Lonicera maackii has also been shown to negatively impact the diversity and growth of tree species within the plant community. In forests of southwestern Ohio, there was a $41 \%$ decrease in species richness of tree seedlings and a $68 \%$ decrease in density of tree seedlings in plots below crowns of Amur honeysuckle, compared to plots placed away from the shrubs (Collier and Vankat 2002). In another study examining the effect of honeysuckle shoot removal on native tree species survivorship, results showed increased survivorship of sugar maple (Acer saccharum Marshall), white ash (Fraxinus americana Linnaeus), Northern red oak (Quercus rubra Linnaeus), and black cherry tree (Prunus serotina Ehrhardt) seedlings with removal of honeysuckle shoots (Gorchov and Trisel 2003). Effects of the related shrub honeysuckle species Lonicera tatarica on herbs and tree species in New England forests included a substantial depression of total herbaceous cover, herb species richness, and density of tree seedlings when cover of the shrub surpassed 30\% (Woods 1993).

Species of Lonicera may attain a competitive advantage and suppress plant vitality via allelopathy. Inhibitory effects were demonstrated in a study by Dorning and Cipollini (2006) in which L. maackii foliar extracts suppressed seed germination of four herbaceous species. A similar study resulted in a decrease in the number and size of fruit 
produced by a small flowering annual, the thale cress Arabidopsis thaliana (Linnaeus), across a range of soil nutrient conditions when exposed to L. maackii extract (Cipollini et al. 2008). After exploring effects of L.maackii extracts on the germination of native grasses and forbs, McEwan et al. (2010) determined fruit extracts showed the strongest evidence of allelopathic activity. While this evidence supports the theory that allelopathy of L. maackii aids in its ability to thrive in many plant communities, it is important to consider that many frugivore-dispersed species contain secondary compounds that enable fruit persistence and vitality (McEwan et al. 2010). For example, the aforementioned study by McEwan et al. in 2010 detected inhibition to seed germination of the same native grasses and forbs by foliar extracts of the native shrub spicebush (Lindera benzoin Linnaeus).

In addition to potentially suppressing the growth, fecundity, and survivorship of other plants, large expanses of Amur honeysuckle have been shown to alter processes within an ecosystem. Studies exploring the effects of honeysuckle on hydrological function, riparian habitat, and forest decomposition have found notable differences between invaded and uninvaded habitats. Boyce et al. (2012) demonstrated 6.0\% of total transpiration in a wetland forest in northern Kentucky with a high density of L. maackii was attributed to trees and vines while vegetation transpiration of an adjacent site with low honeysuckle density was $1.0 \%$ of the total; the additional transpiration equates to approximately $10 \%$ of the stream discharge draining the area. The increase in transpiration of forest stands heavily invaded with honeysuckle may alter the hydrology of the system over time by decreasing water flow available to small ponds and streams, potentially impacting the fauna in these wetlands (Boyce et al. 2012). 
Lonicera maackii has been shown to alter the ecological function of riparian areas as well. Whether high densities of $L$. maackii impact the waterways within these riparian zones was investigated in $3^{\text {rd }}$ order headwater streams in southwestern Ohio (McNeish et al. 2012). The authors assessed the effect of honeysuckle leaf litter on aquatic processes (such as leaf litter input and decomposition) and found honeysuckle leaf litter was broken down four times faster than native ash species (Fraxinus spp.) and American sycamore (Platanus occidentalis Linnaeus) leaves. Honeysuckle leaves contain higher nitrogen stores (low C:N ratios) compared to native plants, which intuitively translates into higher rates of decomposition relative to natives (Blair and Stowasser 2009). Mass groves of honeysuckle alter stream waters of riparian areas by preventing leaf litter of native plants from falling into the stream, due to the thick barrier created by adjacent shrubs (McEwan 2012). A study by McEwan et al. (2012) demonstrated significantly lower volumes of tree leaf throughfall under canopies of Amur honeysuckle, compared to sites away from honeysuckle in natural areas of central Kentucky.

The increase in L. maackii leaf litter and decrease of native plant litter affect decomposition rates not only in aquatic habitats but also in terrestrial habitats. A study in Cincinnati, OH (Blair and Stowasser 2009) compared the decomposition rate of Amur honeysuckle leaf litter compared to two native trees, sugar maple (Acer saccharum) and Northern red oak (Quercus rubra) in both invaded and uninvaded plots. On average, $L$. maackii leaves decomposed three times faster than sugar maple leaves and 21 times faster than Northern red oak (Blair and Stowasser 2009). The exotic leaf litter is broken down at a much faster rate relative to native leaves because the honeysuckle leaves are of higher quality (lower C:N ratios and lower lignin) (Trammell et al. 2012). The more easily 
broken down leaf litter may allow for larger populations of decomposers in a shorter time that in turn create faster decomposition rates in leaf litter from the exotic shrub (Blair and Stowasser 2009).

Differences in the decomposer community of forest floors with Amur honeysuckle leaf litter may be attributed to the accelerated decomposition rates observed (Arthur et al. 2012). Arthur et al. (2012) detected differences in the microbial community of L. maackii leaf litter compared to native plant litter; the microbial communities of both litter types changed over time but still remained distinct from one another.

\section{Amur honeysuckle effects on local fauna}

In addition to vegetation community and landscape scale effects, Lonicera maackii has also been shown to impact both invertebrate and vertebrate fauna. Changes in the annelid and arthropod communities within honeysuckle invaded habitat have been documented, as well as changes in the herptile, small mammal, and bird communities. The dense shrub layer created by L. maackii alters the microclimate of the understory, potentially influencing fauna within the invaded habitat. For example, mean daily temperature and mean daily maximum temperature in forest plots in Missouri was lower in plots invaded by honeysuckle compared to plots with few to no honeysuckle (Watling et al. 2011).

The extent to which L. maackii impacts the invertebrate community is unclear as studies have found conflicting results. A macroinvertebrate group that has been documented to prefer Amur honeysuckle leaf litter and contribute to increased rates of 
decomposition of invaded forests is earthworms (Pipal 2014). A study by Pipal (2014) demonstrated the earthworm preference for Amur honeysuckle leaf litter compared to sugar maple across all seasons in an urban park in Louisville, KY.

Another invertebrate study involved adjacent paired plots in an urban park in Louisville, KY and investigated differences between arthropod diversity in $100-\mathrm{m}^{2}$ paired plots (separated by 3 to 5 meters) with Amur honeysuckle and those where the shrub had been removed. Sticky traps were set one and three years post honeysuckle removal across all seasons except winter. Results of sticky traps one year after removal indicated a 53\% increase in arthropod abundance and a $12.3 \%$ increase in species richness in the removal plots, but no difference in diversity was noted in the third year (Masters 2014). The outcomes of the first year could be a result of increased openness in the plots following removal of the dense shrub layer of honeysuckle and the close proximity of the paired plots could have influenced study results; the long-term impact of honeysuckle on the arthropod community seems negligible based on this study (Masters 2014). However, a similar study of urban and suburban forests in Cincinnati, $\mathrm{OH}$ utilizing paired plots with and without $L$. maackii but separated by at least 30 meters found an increase in species diversity in Psocoptera (barklice) and Coleoptera (beetles) in plots with honeysuckle, compared to plots without honeysuckle (Loomis and Cameron 2013). Buddle et al. (2004) found that hedgerows located next to agricultural fields in southwest Ohio containing L. maackii exhibited the lowest spider diversity compared to riparian forests. Many other factors, such landscape context of the study sites and forest composition, complicate the outcomes of these invertebrate studies such that the overall effect of Amur honeysuckle on the arthropod community of invaded is unclear and may be taxon and 
land-use dependent. The diversity of the invertebrate community is important in that it affects secondary consumers whose diet consists largely of insects.

The diet of most herptiles consists largely of insects. Although there are only a few studies investigating the effects of Amur honeysuckle on herpetofauna, all of them found a decrease in overall diversity (notably frogs and turtles) in invaded areas. McEvoy and Durtsche (2004) examined herpetofauna on the grounds of the Cincinnati (OH) Nature Center and found diversity was significantly greater in the areas uninvaded by honeysuckle compared to invaded areas. Evenness was also greater and two common species of amphibians, the northern slimy salamander Plethodon glutinosus (Green) and the green frog Lithobates (=Rana) clamitans (Latreille), both had larger body masses in uninvaded habitat. However, less common species, primarily snakes, were found more often in invaded areas, suggesting the increase in habitat structure created by L. maackii may be beneficial to some species of herptiles while unfavorable to others (McEvoy and Durtsche 2004).

A similar study by Watling et al. (2011) examined the amphibian community in forested plots with high and low densities of L. maackii and found lower species richness and evenness of herptiles in invaded plots. For one species of frog, the green frog Lithobates clamitans, an increased frog abundance occurring with increasing density of L. maackii more than likely was due to the frog's preference of relatively cool temperatures in the honeysuckle-invaded plots (Watling et al. 2011).

Small mammals have been shown to utilize the dense shrub layer Amur honeysuckle creates as a means of avoiding predation and/or increasing foraging activity. 
Whether the mass production of berries or the change in habitat dimensionality created by L. maackii affects the activity of native mammals was investigated by Dutra et al. (2011) in a wildlife conservatory area in Missouri. Compared to areas of shrub removal, areas with honeysuckle cover had higher activity of two common mice species in the genus Peromyscus and two mesopredators, the raccoon (Procyon lotor Linnaeus) and opossum (Didelphis virginiana Gray); fruit abundance did not seem to influence mammalian activity (Dutra et al. 2011). The relative lack of response of small mammal activity to changes in fruit abundance is expected given fruit is not a substantial part of their diet. The study also indicated rodents only used honeysuckle cover on cloudless nights, suggesting that the preference of honeysuckle by smaller mammals may be dependent on moonlight intensity (Dutra et al. 2011). Nonetheless, the high activity levels reported under honeysuckle cover indicates that some small animal species may prefer the solid shrub thickets of L. maackii. Some of the mammals mentioned are nest predators and may decrease avian fecundity in areas with high densities of honeysuckle, if in fact the mammals prefer these areas to uninvaded stands.

Besides the potential of increased predation due to utilization of cover by predators, Amur honeysuckle has also posed a predatory problem for breeding birds based on its early leaf phenology. L. maackii leaves are typically the first to emerge in early spring and therefore are a popular initial nesting site for birds in invaded areas. A study by Rodewald et al. (2010) determined that nests of Northern cardinals (Cardinalis cardinalis) in L. maackii in early spring demonstrated lower rates of survival compared to native shrubs and another exotic shrub, Rosa multiflora (Thunberg). However, later in the breeding season, nests in L. maackii had the highest relative survival rates. Differences in 
nest survivorship in honeysuckle through time may be a result of decreased predation as nests become more abundant in both native and honeysuckle substrate. Height differences did not seem to be a determinate in this study because nests in native substrate were at the same height as nests in honeysuckle until later in the season, when nests in native plants increased in height (Rodewald et al. 2010). A similar study by Schmidt and Whelan in 1999 found that nests of American robins (Turdus migratorius) in L. maackii had higher daily mortality rates throughout five consecutive breeding seasons, compared to robins nesting in two native shrubs, hawthorns (Crataegus spp. (de Tournefort) and Viburnum spp. (Linnaeus), as well as in native tree species. The higher mortality rates of nests in honeysuckle corresponded with increased predation to those nests compared to nests in native substrate (Schmidt and Whelan 1999). Unlike Rodewald et al. (2010), Schmidt and Whelan (1999) did not observe an increase in nest survivorship in honeysuckle with progression of the breeding season. However, in the Schmidt and Whelan study, nests in honeysuckle were lower in height compared to native plants, potentially allowing for easier access to predators throughout the breeding season. Both studies demonstrate the potential of L. maackii to decrease bird fecundity by acting either as an ephemeral ecological trap or a seasonal trap in the case that lower nest height relative to native plants increases predation rates (Rodewald et al. 2010; Schmidt and Whelan 1999).

\section{Forest composition and surrounding matrix effects on birds}

In contrast to the relatively few studies on Amur honeysuckle and bird interactions, a plethora of studies have been performed examining effects of forest 
composition on bird diversity. James and Wamer (1982) compared North American breeding bird censuses in late successional deciduous forests to coniferous forests and early deciduous forests by examining tree species richness, tree density, canopy cover, and canopy height. Principle Component Analysis (PCA) revealed bird communities on axis one were explained by variation in tree species richness and canopy cover and axis two by canopy height (James and Wamer 1982). It was found that mature forests had the highest bird species richness, but not in those stands with the highest trees species richness, tree density, or canopy height (James and Wamer 1982). Bird species richness was highest in late successional forests, but bird counts were highest at maximal tree species richness and canopy height, demonstrating bird species richness and total number of birds can be driven by different compositional attributes of forest stands. Bird evenness was lowest in the mature forest stands, indicating increased dominance by a few species (James and Rathburn 1981). The lowest bird species richness and density was found in coniferous forests, which had the highest tree density but lowest canopy height and tree species richness (James and Wamer 1982). Based on the results that maximum bird species richness did not correspond to maximum tree species richness or density in mature forests, tree diversity may not always be considered a suitable proxy for approximating bird diversity.

Years ago, Robert MacArthur proposed that foliage height diversity better explains bird species diversity than vegetation diversity does (MacArthur and MacArthur 1961). He also demonstrated that bird species richness was greatest when the amount of foliage in the shrub, mid-canopy and upper canopy layers was approximately equal (MacArthur 1964). This result was determined by dividing habitats vertically into three 
layers and observing birds frequenting the various habitat strata (MacArthur and MacArthur 1961).

It is well established that tropical forests can support more biodiversity than temperate forests, due to more climatic consistencies that prevent the seasonal decreases in population sizes observed in temperate forests (Gaston 2000; Gentry 1992). The conclusion that increased habitat complexity corresponds to higher biodiversity in tropical forests can be applied to forests in temperate regions. Some studies claimed that bird diversity is influenced by the complexity of a habitat by increasing microhabitats and niche availability. For example, a study by Khanaposhtani et al. (2012) found higher bird abundance and species richness in the more complex forests.

Bird diversity can also be influenced by fragmentation of forests and urbanization. Many studies have examined how changes along an urban gradient can influence bird communities. One such study by Blair (1996) in Santa Clara, CA investigated summer resident birds in habitats ranging from an undisturbed preserve to a heavily urbanized business district. Results demonstrated shifts from mostly native species in the less disturbed areas to exotic species in the highly disturbed areas (Blair 1996). Along with changes in community composition, bird diversity also varied depending on the extent of anthropogenic influence. Areas with the highest bird species richness, Shannon Diversity index, and bird biomass were those with intermediate levels of human disturbance (Blair 1996). This outcome corroborates nicely with the intermediate disturbance hypothesis (IDH) which states diversity is highest when a habitat is not disturbed too frequently or infrequently (Connell 1978). An intermediate amount of disturbance provides conditions that are not so harsh few species can survive but, on the other hand, the habitat is not so 
innocuous that it is overrun with dominate species; both extreme levels of disturbance will lower diversity. Blair described the types of birds in rural, suburban, and urban areas as "urban avoiders, urban adapters, and urban exploiters" respectively. The number of bird species categorized as "urban adapters" made up the large majority of birds in the study found in suburban areas of intermediate disturbance (Blair 1996). A study by Marzluff (2005) in the Seattle, WA metropolitan area also supported IDH; peak bird diversity occurred in areas of intermediate anthropogenic disturbance. Marzluff believed this increase in bird diversity is due to increased heterogeneity within the intermediately disturbed land (Marzluff 2005).

\section{Previous studies examining the impact of honeysuckle on birds}

Previous studies have documented the abundance of bird species frequenting areas with Lonicera maackii. Gleditsch and Carlo (2011) examined how abundance of Lonicera fruit influences native frugivores in a large expanse of urban, forested, and agricultural landscape invaded by honeysuckle in central Pennsylvania. The Lonicera shrubs present in the study site varied from 0 to greater than 10,000 fruits per shrub. Bird counts were performed at 50 locations within the study area two times per location in the fall in order to coincide with honeysuckle peak fruit production. They found that abundance of a few native frugivores positively correlated with abundance of Lonicera fruit; namely abundance of gray catbirds (Dumetella cardolinensis Linnaeus), robins, and American goldfinches (Spinus tristis Linnaeus) positively correlated with Lonicera fruit. The abundances of two woodpecker species, the red-bellied woodpecker (Melanerpes 
carolinus Linnaeus) and downy woodpecker (Picoides pubescens Linnaeus) along with a ground-foraging granivore (the dark-eyed junco; Junco hyemalis Linnaeus) negatively correlated with Lonicera fruit abundance. There was not a correlation between land cover types (urban, forest, or agricultural) and abundance of the dominant frugivore species; instead, areas high in Lonicera fruit quantity may prove an important ephemeral food source for some common frugivores (Gleditsch and Carlo 2011).

Another study of bird-honeysuckle interactions was performed by McCuster et al. (2010) comparing bird communities within five rural forested areas of central Illinois with Lonicera maackii to five forests consisting of only native shrubs during the summer and winter seasons of two years. During the breeding season, a large increase in density of understory species, namely Northern cardinals, was observed in areas with Lonicera along with a decrease in density of some canopy species, such as Eastern wood-pewees (Contopus virens Linnaeus). PCA revealed bird community differences between Lonicera presence and absence sites among seventeen common species. In addition to cardinals, densities of gray catbirds (Dumetella carolinensis Wood), American robins, and blue jays (Cyanocitta cristata Linnaeus) were greater in areas with Lonicera compared to areas without. In addition to Eastern wood-pewees, various species within the family Paridae (including chickadees and tufted titmice) were half as common in areas of Lonicera compared to those without. Examining habitat guilds, mid- and understory guilds were more common in areas with Lonicera while abundance of canopy birds in both treatment types was comparable. In winter, an increase in density of frugivores (robins) occurred in areas with Lonicera present. However, a difference in community composition between areas with and without Lonicera was not observed in the winter (McCuster et al. 2010). 
The increase in density of mid- and understory species in the breeding season in the study by McCuster et al. (2010) could be a result of the dense shrub layer habitat within areas with Lonicera. The increase in density of frugivores in areas with Lonicera in the winter could be due to the ability of the fruits to remain late into the fall and early winter suggesting L. maackii is an important food source for overwintering birds (Ingold and Craycraft 1983; McCuster et al. 2010). Lonicera maackii has been documented as a common food source for some frugivores, such as American robins and cedar waxwings (Ingold and Craycraft 1983).

\section{The current study}

The majority of past studies performed to investigate the relationship between Amur honeysuckle and birds involve effects on survivorship, fecundity, and foraging. The general aim of my study is to investigate if species-specific effects of Lonicera maackii on bird communities exist. I posed three general hypotheses (described below) to answer this question. Land managers of the Midwest and Southeast regions of the US have been making strides rid (or at least control) Amur honeysuckle within their managed properties, and many of them question whether they are doing harm to bird communities dwelling within these invaded areas by doing so (personal communication with Olmsted Parks Conservatory personnel). Local bird enthusiasts also have expressed concerns about the impact of honeysuckle removal upon birds (personal communication with members of the local birdwatching club, the Beckham Bird Club). Are there species that prefer and utilize areas with L. maackii more often than areas without that may decrease 
in local population size if these shrubs are removed? On the other end of the spectrum, are there species that avoid areas invaded by the shrub altogether making it difficult to find suitable habitat in areas vastly occupied? By performing a regional study containing forested stands varying in their percent of honeysuckle cover from zero percent to greater than fifty percent, I hope to answer these questions and provide management advice to land stewards and bird enthusiasts alike.

\section{Methodological Approach}

The previous studies described above that had examined effects of Lonicera maackii on birds were only performed during the breeding and winter seasons rather than across all seasons, and/or typically only involved one large expanse of land. The major goal of my study is to determine the effect of varying densities of honeysuckle (some of which are completely void of the shrub) on bird communities within forest stands throughout the Louisville Metropolitan Area. Every season was investigated over the course of a two year sample period (2013-2014). The stands selected are similar in some respects; they all have established hiking trails that run through forest stands of similar composition. The trees common to the region [maple species (Acer spp.), ash species (Fraxinus spp.), and oak species (Quercus spp.) to name a few] are present in all stands, but the relative importance of each major tree species differs. The selected stands do differ greatly with respect to percent cover of honeysuckle (if present), the extent of anthropogenic influence inside and outside the forests (in particular, the existence and proximity of nearby residential housing), and other woody vegetation. 


\section{Question 1: How do bush honeysuckle and characteristics of forest stands affect bird communities?}

The study looked at how forests impact bird diversity, particularly determining the potential effects of Amur honeysuckle density. Are there differences in avian diversity based on the density of Amur honeysuckle present in a habitat? If so, are there seasonal differences? I hypothesized some bird species will prefer habitats with honeysuckle but more bird species will prefer habitats without honeysuckle because of the life history traits of the birds. Therefore, I predicted that bird diversity will decrease with increasing percent honeysuckle cover across all seasons.

Opposed to honeysuckle, differences in bird communities may be more dependent on the compositional metrics of the forest stands. i.e., tree diversity, average tree height, percent canopy cover, and anthropogenic influence determined by surveying the amount of man-made objects within and surrounding the forest stands. I predicted that canopy cover will have a direct effect on bird diversity because more closed habitats provide increased protective cover for small birds. Also, higher average tree heights may indicate more variation in habitat strata; this increased variation may positively impact bird diversity by increasing niches to be exploited. The extent to which humans have impacted a forested area may also influence bird diversity. Urbanized parks may have a less diverse avian community compared to more undisturbed forest stands in more rural environments. On the other hand, urban areas may have equally diverse (or even more diverse) bird communities consisting of urban-adapted birds. 


\section{Question 2: What underlying mechanisms are causing fluctuations in avian diversity due to Amur honeysuckle (if fluctuations in bird diversity occurred)?}

If bird diversity is influenced by Amur honeysuckle, what is causing the changedifferences in species, families of birds, or habitat preference that influences either an inclination or avoidance of forest stands with honeysuckle? I hypothesized that honeysuckle will influence bird communities through multiple mechanisms which will cause an overall decrease in diversity. Species richness may not differ between areas of high and low percent honeysuckle cover, because birds favoring honeysuckle in highdensity honeysuckle stands (understory birds) could replace those birds avoiding honeysuckle in low-density honeysuckle stands (canopy birds). However, evenness will decrease in stands with higher percent honeysuckle cover, therefore decreasing overall bird diversity.

I predicted the decrease in evenness will occur because understory birds (such as cardinals, sparrows, and thrushes) will favor forested areas with honeysuckle. Areas with high densities of Amur honeysuckle create a vast shrub habitat favored by certain song bird species, notably Northern cardinals, Eastern towhees, chipping sparrows, whitethroated sparrows, and American robins. I expected that birds commonly observed in the understory will be positively influenced by honeysuckle density, especially in the spring and summer.

The next reason I believed bird evenness would decline with honeysuckle density is because bird species that prefer the mid and upper canopy may avoid areas of dense honeysuckle. Birds typically found above the shrub canopy include Eastern wood-pewees 
and other flycatchers of the family Tyrannidae, migratory warblers, woodpeckers, and chickadees and titmice of the family Paridae. The visual impediment to the forest floor and of predators created by the sprawling limbs of honeysuckle may deter upper canopy species from areas with high honeysuckle density. Also, areas dense with honeysuckle may have fewer tall, old growth trees favored by canopy birds. I predicted honeysuckle density will have a negative association with the abundance of these canopy species (Eastern wood-pewees, Carolina chickadees, tufted titmice, red-bellied woodpeckers, downy woodpeckers, and migratory warblers).

In the fall and early winter, honeysuckle produces a multitude of fruit that may attract frugivores. Some omnivores, notably thrushes, are known to switch their diet to fruit during the fall and winter when invertebrates are scarce. The most prevalent thrush species in North America is the American robin, which has been documented consuming honeysuckle fruit and is known to be an important disperser of honeysuckle seeds (Bartuszevige and Gorchov 2006). The last reason I believed bird evenness would decrease with honeysuckle density is because the abundance of robins will be positively influenced by honeysuckle density in the fall.

\section{Question 3: Are there correlations between honeysuckle density and characteristics of forest stands?}

In forest stands invaded by Amur honeysuckle, tree diversity and honeysuckle density may be negatively correlated. As discussed earlier, Amur honeysuckle has the ability to drastically alter habitats in heavily invaded areas by creating a dense understory 
and potentially affecting the growth and survivorship of other trees and shrubs, particularly native plants. Where honeysuckle comprises a large proportion of the woody biomass, it may limit the growth of other tree and shrub species. Alternatively, honeysuckle may be more capable of flourishing in less diverse habitats with fewer competitors. Both hypotheses suggest that percent honeysuckle cover and tree diversity of forest stands will be negatively correlated. Studies in Ohio have shown that tree seedling species richness and density were inversely related to honeysuckle cover, and that tree seedling richness was higher in plots grown away from honeysuckle crowns compared to plots below the shrubs (Collier and Vankat 2002; Hutchinson and Vankat 1997). Shrub honeysuckle could also influence the overall height of the vegetation and/or be more capable of invading those areas with fewer tall, old growth trees. Hutchinson and Vankat (1997) demonstrated an inverse relationship between honeysuckle cover and total tree basal area in forests of southwestern Ohio, suggesting that larger, taller trees may be more resistant to honeysuckle invasion. Forest stands with fewer large-boled trees tend to have less canopy cover; therefore percent honeysuckle cover may negatively correlate with percent canopy cover due to its ability to exploit open areas. In the same study by Hutchinson and Vankat (1997), canopy cover and shade intolerance index were shown to have an inverse relationship with honeysuckle cover as well. Anthropogenic influences may also be positively correlated with honeysuckle density; more urbanized forests disturbed by human activity thus are predicted to have a higher density of honeysuckle compared to less disturbed forests. An inverse relationship between distance to an urban center and honeysuckle cover was found in a study of forest communities in Ohio (Hutchinson and Vankat 1997). Other studies examining vegetation composition along 
gradients extending outside of the urban hub of Louisville, KY found L. maackii was associated with habitat surrounded by development and in higher densities closer to the city center along highway corridors (Trammell and Carreiro 2011; White et al. 2014). 


\section{CHAPTER 2: DESCRIPTION OF STUDY SITES}

The area of study lies within the Louisville, KY Metropolitan Area and includes forested areas within Southern Indiana and Northern Kentucky. The Louisville Metropolitan Area is categorized as having a warm temperate climate according to the Köppen climate classification; this climate type is characterized by four distinct seasons in which summers are typically hot and humid and winters vary from mild to cold (Kottek 2014). The average annual temperature is $14.6{ }^{\circ} \mathrm{C}\left(58.2^{\circ} \mathrm{F}\right)$ and average annual rainfall is $1,140 \mathrm{~mm}$ (44.9 inches) (Canty 2014).

Approximately 360 different bird species have been seen in the region out of the 925 bird species in North America (Kistler 2015). Roughly half of the 360 species are natives and half are migratory. The forested areas I investigated mostly contain songbirds within the order Passeriformes, which includes roughly half of the 10,000 or so bird species in the world (Kistler 2015).

Forest stands selected for the study were determined by assessing local parks and preserves within the Greater Louisville Area and the surrounding rural areas in Kentucky and Indiana. The parks and their forest stands were selected using three criteria. First, the park had to be at least 100 acres (40 ha) in size, but have a substantial forest stand with mature trees within the park. Second, the forest stand had to have either a moderate density (>10\% cover) of Lonicera maackii, or currently have little (<1\% cover) to no 
Amur honeysuckle present. Third, the forest stand had to possess within its boundary an established hiking trail longer than one kilometer. The trail needed to be: 1) in a primarily mesic environment, 2) flat (or lacking in steep cliffs/drastic elevation changes throughout), and 3) primarily surrounded by forest (only small sections of the trail could be within $20 \mathrm{~m}$ of a road). Fourteen forested stands were selected: seven stands in which honeysuckle was present and seven stands in which there were very few to no Lonicera shrubs present (Figure 1). Unfortunately, during the first year of surveys (May 2013), management in one of the stands (Seneca Park) decided to begin removal of honeysuckle along a portion of the trail I utilized. The forest stand was so badly disturbed that I could no longer include it in my research and was forced to abandon it, leaving six stands with relatively high densities of honeysuckle and seven with little or no honeysuckle present. 


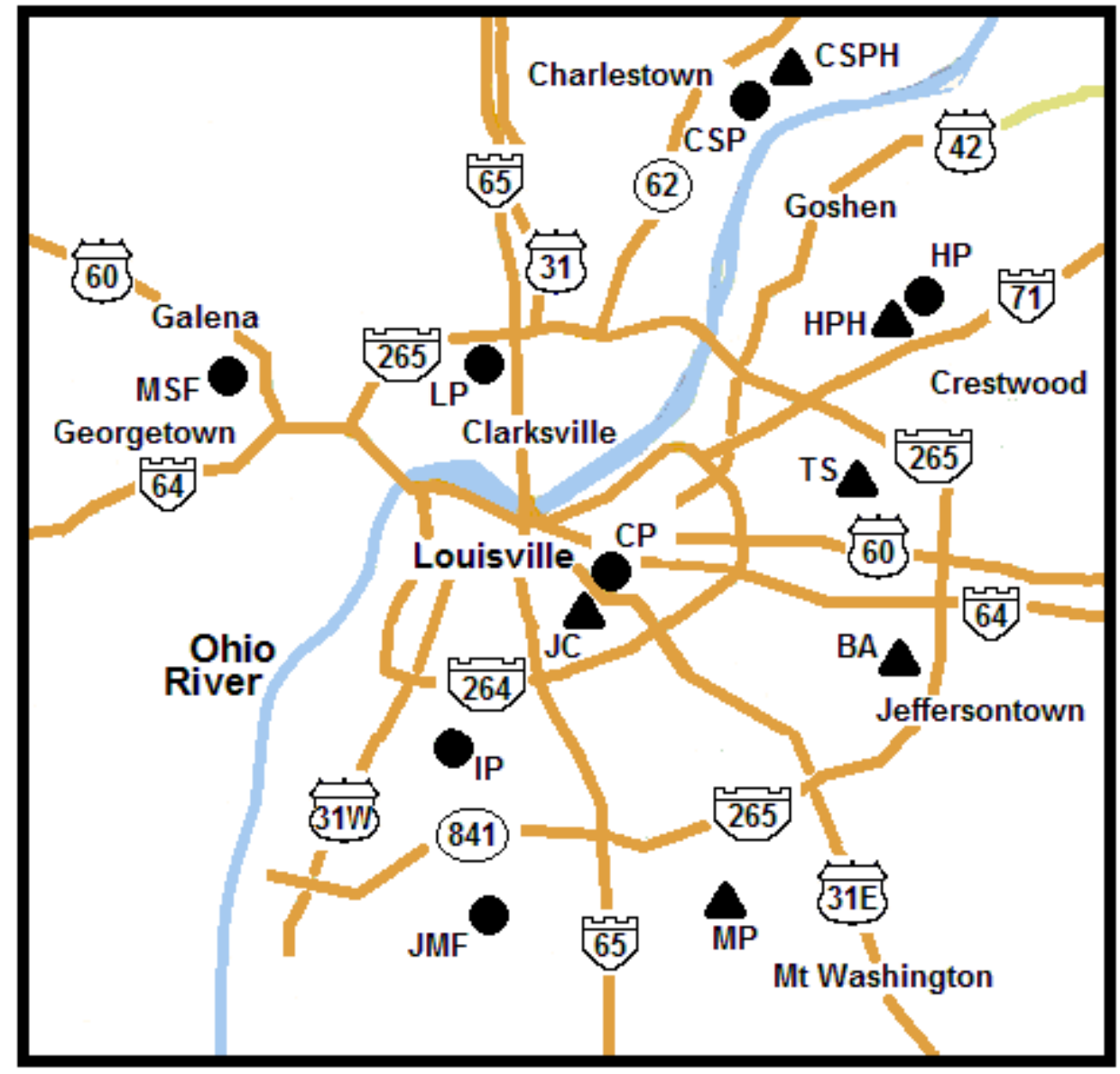

Figure 1. Map of the 13 forest stand locations used in the study. Triangles indicate stands that contained $>10 \%$ honeysuckle cover; circles indicate stands with little or no honeysuckle present. The abbreviations for the forest stands are as follows: Blackacre Nature Preserve (BA); Charlestown State Park (CSP); Charlestown State Park with honeysuckle (CSPH); Cherokee Park (CP); Horner Preserve (HP); Horner Preserve with honeysuckle (HPH); Iroquois Park (IP); Jefferson Memorial Forest (JMF); Joe Creason (JC); Lapping Park (LP); McNeely Lake Park (MP); Mount St. Francis Seminary (MSF); EP ‘Tom’ Sawyer State Park (TS). 


\section{Blackacre State Nature Preserve and Historic Homestead (honeysuckle)}

Blackacre State Nature Preserve (BA, Figure 1) is a historical 110-hectare nature preserve surrounded by suburban neighborhoods in Louisville, $\mathrm{KY}\left(38.19^{\circ} \mathrm{N}, 85.53^{\circ} \mathrm{W}\right)$ (Kimball 2015); it was part of a large farm dating back to 1785 . The land since has been expanded to include adjacent forested habitat, ponds and small karst streams. According to the preserve's official website, the majority of the forest has remained unchanged for the past 200 years, indicating that it has not been logged in the last two centuries, if at all (Josey 2015). Part of the preserve still acts as an active farm with livestock. There are several established hiking trails through the preserve. The preserve also has a visitor's center and is open to the public, making it a popular site for school field trips. Most of the preserve consists of an old-growth forest, but anthropogenic disturbance (as well as its suburban location) has allowed for invasion by shrub honeysuckle. In 2005, honeysuckle removal (via cutting and spraying with an herbicide) occurred at the trail head and off the trail in both directions 30 meters (personal communication with Bryan Thompson, Environmental Education at Jefferson County Public Schools); I used the same trail for bird surveys, starting the transect past the impacted site. Honeysuckle has since reestablished at the trail head.

\section{Cherokee Park (no honeysuckle)}

Cherokee Park (CP, Figure 1) is a municipal park designed in 1891 by Frederick Olmsted $\left(38.24^{\circ} \mathrm{N}, 85.69^{\circ} \mathrm{W}\right)$ (Yost 2015). Cherokee was the first park established for the Frederick Law Olmsted Parks in Louisville, KY. Its 157 hectares consist of open grassy 
fields, forested areas, and winding roads surrounding Beargrass Creek, the stream that drains the major watershed within Greater Louisville. The park was created initially from pasture land; many trees and shrubs (including many exotic species) were planted in addition to the pre-existing forested area (DeHart 2015). In 1974, a major tornado ripped through the park, resulting in the death of thousands of mature trees (Share, 1976). Two years after the tornado, efforts were made to restore the park with replanting, but during the two year delay, exotic vegetation invaded the heavily disturbed park (Carreiro and Zipperer 2011). The majority of the invaders were buckhorns (Rhamnus) and honeysuckle (Lonicera) species that continued to flourish and spread throughout the park, eventually leading to the reduction or elimination of native species (Carreiro and Zipperer 2011). Since 2005, but particularly from 2009 to 2012, Louisville Olmsted Parks Conservancy has made a concerted effort to eliminate (or at least decrease the abundance of) these exotics (Carreiro and Zipperer 2011). Currently, populations of these invasive species are low relative to their previous levels, except for nine $10 \mathrm{~m}$ X 10m experimental plots located throughout the park that still contain intact Amur honeysuckle. There are many man-made structures throughout the park, including a fountain, large pyramidshaped picnic area, basketball courts, baseball field, walking bridges, a golf course, a dog park, and a paved scenic loop. The unpaved hiking trail used in this study is found in the central section of the park that was less affected by the tornado and honeysuckle was not present (Carreiro and Zipperer 2011). 


\section{Charlestown State Park (honeysuckle and no honeysuckle)}

Charlestown State Park is in Clark County, Indiana $\left(38.43^{\circ} \mathrm{N}, 85.63^{\circ} \mathrm{W}\right)$

encompassing approximately 2,063.90 hectares (Clark 2015; Kimball 2015). It once was a relatively untouched portion of a 6,070 hectare Indiana Army Ammunition Base with no known history of ever being logged (Clark 2015). It is bordered on the south and west by the Ohio River and one of its tributaries, Fourteen Mile Creek, runs through the park. With elevation changes of over 200 meters, rugged terrain and steep ravines comprise some of the land (Clark 2015). The park offers many hiking trails and camping grounds. Despite its amenities, it is still a relatively large expanse of preserved land. There are two stands in Charlestown State Park used in this study. One hiking trail (CSPH) runs through a stand located in the northern section of the park with a considerable amount of honeysuckle present. No honeysuckle is present near the hiking trail at the second stand (CSP, Figure 1) located approximately one km away from the first stand.

\section{Horner Nature Preserve (honeysuckle and no honeysuckle)}

Horner Nature Preserve is an 81 hectare wildlife refuge located on property

donated to the University of Louisville in the early 1960s by the Horner Family. A total of 200 hectares of farmland surround the sanctuary in Oldham County, KY $\left(38.34^{\circ} \mathrm{N}\right.$, $\left.85.53^{\circ} \mathrm{W}\right)$ (Observatory History 2008; personal observation). The majority of the preserve is undeveloped except for a gravel road, an astronomical observatory, and the remains of a few small buildings dating back to the $19^{\text {th }}$ century (Observatory History 2008). The South Fork of Harrods Creek (a tributary of the Ohio River) and one of its 
small unnamed tributaries run along the north and south sides of the sanctuary. As in Charlestown State Park, two stands in the sanctuary were used in this study. One hiking trail winds westward and southward along the northwestern edge of the sanctuary and the stand (HP) contains no honeysuckle. A second hiking trail where a substantial amount of Amur honeysuckle was present is in a hydric, lowland area surrounding a pond and a tributary of Harrods Creek (HPH, Figure 1). The majority of the trail surrounds a pond which may occasionally flood washing away ground cover.

\section{Iroquois Park (no honeysuckle)}

Iroquois Park (IP, Figure 1) is a municipal park in Louisville, KY. As is Cherokee Park, the natural areas in Iroquois Park are managed by a member of the Louisville Olmsted Parks Conservancy $\left(38.09^{\circ} \mathrm{N}, 85.47^{\circ} \mathrm{W}\right)($ Yost 2015). Established in 1888 , this 294-hectare park, with its rolling knobs, rugged topography, and mature forests, was originally considered Louisville's own "Yellowstone" (DeHart 2015). Currently it contains a wide variety of conveniences including many hiking trails, roads, horse paths, picnic areas, playground area, an amphitheater that can accommodate 2,366 people, and many other extracurricular amenities (DeHart 2015; Ghose 2015). The hiking trail selected for this study starts at the northern edge, winding southward along the western edge of the park. Efforts to remove invasive plant species, including Amur honeysuckle, have occurred in the park; however, the area utilized in the study was centrally located in the northeast section of the park and exotic invaders were only prevalent along edges (personal observation). 


\section{Joe Creason Park (honeysuckle)}

Joe Creason Park (JC, Figure $\left.1,38.21^{\circ} \mathrm{N}, 85.71^{\circ} \mathrm{W}\right)$ is a municipal park in Louisville, KY established officially in 1966 (Ghose 2015; Kimball 2015). Previously the area was a horse farm with some of the land used for growing tobacco and orchard trees (Amburgey 2015). The park is adjacent to the 17-hectare Beargrass Creek Nature Preserve and sits at the south divergence of Beargrass Creek, which drains the major watershed found in Greater Louisville (Ghose 2015). The park itself is 25.25 hectares and has nine tennis courts, hiking trails, a playground, and picnic shelter (Amburgey 2015). More than likely due to its high level of anthropogenic disturbance, the park is heavily invaded with Amur honeysuckle. Shrub removal efforts within five meters at the head of some hiking trails have been made but honeysuckle abundance is still high in the park. The hiking trail selected for this study runs through the wooded areas of the combined 42 hectares of the park and the adjacent nature preserve.

\section{Jefferson Memorial Forest (no honeysuckle)}

Jefferson Memorial Forest (JMF, Figure 1) is the largest municipal urban park in the United States, encompassing 2,516 hectares. It is located 15 miles south of downtown Louisville, $\mathrm{KY}$ in the Knobs region $\left(38.0351^{\circ} \mathrm{N}, 85.4823^{\circ} \mathrm{W}\right.$ ) (Amburgey 2015; Yost 2015). In 1944, the park area was originally intended to be a tribute to Kentucky veterans (Ghose 2015). It expanded over time and was eventually designated as a National Audubon Society (nonprofit environmental conservation organization) wildlife refuge (Ghose 2015). In 2004, a tornado destroyed some of the hiking trails, causing them to be 
closed temporarily (Ghose 2015). Currently, the refuge includes second growth hardwood forests, a 2.2 hectare lake, 35 miles of hiking trails, 12 miles of horse trails, and a campground (Amburgey 2015). The hiking trail examined in this study is located just north of Tom Wallace Lake. The sanctuary has experienced invasion by some exotics, including Amur and Japanese honeysuckle, but removal efforts have been made and have proven successful up to this point (Ghose 2015; personal observation). The area of the park used in the study was centralized and consisted of an old-growth, mature woodlot that was unaffected by exotic plants, which tended to be found more commonly along the perimeter of the forest and in areas frequently disturbed by human activities (personal communication with Bennett Knox, Administrator of Metro Parks, Jefferson Memorial Forest).

\section{Lapping Park (no honeysuckle)}

Lapping Memorial Park (LP, Figure 1) is a municipal park in Clarksville, IN and is 143.36 hectares in size. It includes a golf course, driving range, softball fields, basketball and tennis courts, and an outdoor amphitheater $\left(38.2030^{\circ} \mathrm{N}, 85.54613^{\circ} \mathrm{W}\right)$ (Clarksville Parks \& Recreation, 2015; Yost 2015). Silver Creek, a large stream that drains into the Ohio River, borders the northern and western portions of the park (Clarksville Parks and Recreation 2015). The hiking trail used in this study runs westward along the northern portion of the park, following Silver Creek. 


\section{McNeely Lake Park (honeysuckle)}

McNeely Lake Park (MP, Figure 1), established in 1961, is one of the largest Louisville Metropolitan Parks in Louisville, KY encompassing 122.2 hectares $\left(38.05^{\circ} \mathrm{N}\right.$, 85.38 $\mathrm{W}$ ) (Amburgey 2015; Yost, 2015). The park includes a 19-hectare fishing lake (McNeely Lake), horse trails and stables, tennis and basketball courts, a Korean War Memorial, and model airplane flying fields (Ghose 2015). The trail examined in this study runs from the southernmost section of the park towards McNeely Lake to the north.

\section{Mount St. Francis Seminary (no honeysuckle)}

Mount St. Francis Seminary (MSF, Figure 1) is an unincorporated community owned by the Province of Our Lady of Consolation of the Conventual Franciscan Friars located in Floyd County, Indiana $\left(38.2011^{\circ} \mathrm{N}, 85.5413^{\circ} \mathrm{W}\right)$ (Mount Saint Francis Center for Spirituality, 2015; Yost, 2015). The wildlife sanctuary on the property, which is open to the public, encompasses 161.87 hectares consisting of hiking trails, open fields, large mature forests and a large lake (Mount St. Francis Lake, Mount Saint Francis Center for Spirituality, 2015). The natural components of the area have been well-preserved with few man-made structures. The trail used in this study is found in the western portion of the wildlife sanctuary, running part of the way along an unnamed tributary of the Yellow Fork of Little Indian Creek, itself a tributary of Indian Creek, which subsequently drains the Ohio River. 


\section{E.P. 'Tom' Sawyer State Park (honeysuckle)}

E.P. 'Tom' Sawyer State Park (TS, Figure 1) is a 223-hectare urban park located in the northeastern of Louisville, KY $\left(38.1704^{\circ} \mathrm{N}, 85.3334^{\circ} \mathrm{W}\right)($ Amburgey 2015 ; Yost 2015). A portion of the land was originally used as farmland for a mental health hospital in the early twentieth century. The Commonwealth of Kentucky purchased the land from the hospital in 1969; the Kentucky Department of Parks leased the land and officially opened the park in 1974 (Amburgey 2015). Goose Creek, a tributary of the Ohio River, flows within the western portion of the park. The park currently has many amenities available to the public, including an activities center complete with a pool, weight room, gymnasium and indoor courts as well as 14 soccer fields, 12 tennis courts, softball fields, a one mile fitness trail, several nature trails, a model aircraft field, a dog park, various playgrounds and picnic areas, and an urban astronomy center (Amburgey 2015). The hiking trail used in this study is located in the eastern section of the park, running part of the way along Goose Creek. 


\section{CHAPTER 3: STUDY METHODS}

\section{Vegetation surveys}

Over the summer of 2013, vegetation surveys were performed at the 13 selected forest stands in the Greater Louisville Metropolitan Area along a one km hiking trail through each forest. Ten transects perpendicular to the trail were spaced 100 meters apart; the first transect was placed 50 meters from the trail head (see diagram on pages 131-132 of Appendix 1). These transects were 40 meters in length (20 meters from the center of the trail on both sides). A Global Positioning System was used at each transect to take longitude, latitude, and elevation readings. Measuring tape was extended 20 meters from the center of the trail on each side of the trail. Trees and shrubs above two meters tall and extending over the transect were identified to species; some very closely related species were identified to genus because of the difficulty of distinguishing between species (i.e., Northern red oak and Eastern black Oak were combined in Quercus). The intercept length (amount of foliage of each tree or shrub intersecting the transect) and DBH (or height) of each individual tree or shrub was measured directly. If the tree divided into two or more trunks below a height of 1.5 meters), the largest trunk was measured; the single trunk was measured if multi-trunks occurred above 1.5 meters. Height was estimated by the observer for trees and shrubs $<5 \mathrm{~m}$ or using a clinometer (for trees $>5 \mathrm{~m}$ ). Height was not measured for every tree because of the large amount time required to measure every tree; if height was not measured, DBH was measured using 
diameter tape. A height versus DBH regression was later compiled for each tree species observed in each stand in order to determine the heights of trees where height measurements were not directly measured in the field. Height and DBH of common tree species were measured at all stands after vegetation surveys in order to compile height versus DBH regressions for each tree species.

Intercept length of understory vegetation reaching heights of 1 to 2 meters was measured at each transect. The percentage of bare ground was measured using $1 \mathrm{~m}^{2}$ quadrats every 10 meters along each transect. The location of each $1 \mathrm{~m}^{2}$ quadrat was determined by a random number generator and was measured on alternate sides of the transect; a total of 10 quadrat measurements were taken at each transect. Percent canopy cover was measured every 10 meters along each transect using a densiometer. A total of four canopy cover readings at 90 degrees to each other were taken at each 10-meter interval along each transect. This measurement was used to determine the percent of open sky. A total of 400 meters of transect data was collected in each of the 13 stands.

\section{Estimation of anthropogenic impacts}

In order to determine the extent to which each stand was influenced by humans, an 'Anthropogenic Index' (AI) metric was created and used. This measurement provides a quick measure of the anthropogenic impacts of the landscape around the forest transect and was performed in the winter of 2014 before spring budding occurred. The tool used to conduct the surveys was a polyvinyl chloride pipe with a length of $28 \mathrm{~cm}$ and an inner diameter (OD) of $5 \mathrm{~cm}$. Along the trail of each stand, a measure of anthropogenic 
influence was taken every 100 meters along the kilometer trail after the first 50 meters into the trail (the anthropogenic indices were taken at the same locations along the kilometer as the vegetation transects). Measurements were taken at 10 locations along the trail and 10 times at each location. Field of view was selected at each location by closing the eyes and rotating clockwise 360 degrees taking 10 measurements total during the rotation. At each point, I held the scope at a 90 degree angle level with my eye; my eye height is 61.25 inches $(1.56 \mathrm{~m})$. The maximum distance at which any objects were identified was approximately 200 meters and the maximum field of view was approximately 150 meters. I looked through the scope and identified whatever lay within the field of view and categorized that view as follows:

\begin{tabular}{|l|l|}
\hline Category & Type \\
\hline A & 'Miss' (forest; no discernible human structures visible) \\
\hline B & Residential (including driveways) \\
\hline C & Business building/parking lot or any non-residential building \\
\hline D & Road(s) and paved trail(s) \\
\hline E & $\begin{array}{l}\text { Agricultural/recreational (field/pasture/ball fields/golf } \\
\text { courses) }\end{array}$ \\
\hline F & Miscellaneous man-made structure \\
\hline
\end{tabular}

A potential bias to this approach is that the trails could vary in terms of slope and elevation thereby potentially affecting the aspect at every measurement location. In some instances, the elevation or slope of the trail may cause a manmade object to be missed because the scope is kept parallel with the ground. However, because the trails used were either flat or with little slope, the distances viewed within the scope were similar at all locations. 
The results of anthropogenic surveys were utilized by totaling the number of "anthropogenic hits," (i.e., a manmade object was seen in the field of view) in categories B through E listed above and excluded unpaved trails and trail bridges (category F). The percentage of hits was used as the representative AI metric for the stand. The AI metric thus ranged from 0 to 100; 0 indicating no anthropogenic influence (no humanconstructed objects other than unpaved trails were observed in the field of view) and 100 indicating the maximum possible anthropogenic influence (in each field of view, a manmade object was identified).

\section{Bird surveys}

A survey of the bird community in each of the 13 stands was performed once each season for two years in 2013 and 2014 by counting birds along the hiking trail. The temperature, relative humidity, wind, cloud cover, and additional conditions (such as fog, snow, or frost) were obtained from The Weather Channel on the morning of the survey, or by personal observation. On a given day, surveys were not performed during any type of precipitation, wind conditions greater than $20 \mathrm{mph}$, and/or temperatures that differed by more than 10 degrees Celsius from the average local temperature for that date, according to The Weather Channel. Surveys were conducted along 1 kilometer of an established hiking trail within each park or preserve approximately 1.5 hours after sunrise; the bird counts occurred at the transect sites used in the vegetation study discussed previously. All birds were identified visually and/or acoustically if they were within 20 meters of either side of the trail. The location of the birds in the vertical 
vegetation structure of a habitat was delineated as follows: $>15$ meters=upper canopy, 2.5 to 15 meters=mid-canopy, $<2.5$ meters=understory, 0 meters=ground. Birds flying by were not included as observed in the habitat. A steady walking pace was maintained throughout the survey, except for those occasions when I slowed or stopped in order to use binoculars for bird identification. Each bird count was between 30 and 45 minutes in duration. 


\section{CHAPTER 4: FOREST STAND COMPOSITION}

\section{Statistical Analysis}

First, the percent cover of each tree genus (represented by the importance value $\left[\mathrm{p}_{\mathrm{i}}\right]$ ) was determined at each forest stand by taking the total intercept length of all members of the genus along the total transect length measured (400 meters). The importance value of a tree genus could exceed $100 \%$ when the foliage of trees in the same genus overlapped and caused the total intercept length to exceed the total transect length measured. In addition to tree genera richness ( $\mathrm{S}$, the number of genera present), I calculated two alpha diversity metrics of each stand's vegetation composition: Shannon

Diversity Index $\left(\mathrm{H}, \mathrm{H}=-\Sigma p_{i}\left(\ln p_{i}\right)\right)$ and Simpson diversity index $\left(\mathrm{D}, \mathrm{D}=\Sigma\left(p_{i}\right)^{2}\right)$. The $\mathrm{H}$ and $\mathrm{D}$ metrics were then converted into $\mathrm{N}_{1}$ and $\mathrm{N}_{2}$ metrics $\left(\mathrm{N}_{1}=\mathrm{e}^{\mathrm{H}}\right.$ and $\left.\mathrm{N}_{2}=1 / \mathrm{D}\right)$. The $\mathrm{N}_{1}$ and $\mathrm{N}_{2}$ metrics have values that are analogous to the number of species that would be found in a stand if all species were equally common (i.e., they all had identical importance values), thus allowing for a direct comparison with species richness S (Hill 1973; Krebs 1999).

Percent honeysuckle cover was calculated as the percent of the total transect length measured at each stand $(400 \mathrm{~m})$ that was covered by Lonicera shrubs. Percent honeysuckle cover was used as an estimate of honeysuckle density. Percent understory cover is the percent of the total transect length measured at each stand (400 meters) that was covered by vegetation that was one to two meters high (intercept length of vegetation 
one to two meters high along transects). The metric 'Percent bare ground' is the percent

of the $1 \mathrm{~m}^{2}$ quadrats measuring ground cover at each stand (100 quadrats) that was not covered by live plants (seedlings, grasses, forbs, ferns or mosses). The metric 'Percent canopy cover' was calculated as the percent of the total densiometer measurements taken at each stand (200 measurements) that was covered by the canopy. The metric 'Percent open sky' is the opposite of 'Percent canopy cover' and is the percent of the total densiometer measurements (200 measurements) taken at each stand that was open sky.

\section{Results}

Summary descriptions of each stand, including tree genera diversity (Simpson's diversity $\mathrm{N}_{2}$ value) and all other measurements taken [percent honeysuckle cover, anthropogenic index, mean tree height, three tree genera with the highest percent cover, mean elevation, percent bare ground/percent ground cover, percent understory cover, and percent canopy cover/percent open sky] are listed below by park in order of increasing percent honeysuckle cover. A more exhaustive table is available in Appendix 2 on pages $133-135$. 
Table 1. Information for the 13 forest stands used in the study. Anthropogenic index (AI) is a value ranging from 0 to 100 indicating extent of human impact; Tree diversity $\left(\mathrm{N}_{2}\right)$ is Simpson's Diversity Index $\left(\mathrm{N}_{2}=1 /\left(\Sigma\left(p_{i}\right)\right)^{2}\right)$ representing the diversity of tree genera.

\begin{tabular}{|c|c|c|c|c|c|c|c|c|c|c|c|c|c|}
\hline $\begin{array}{l}\text { Forest } \\
\text { Stand }\end{array}$ & $\begin{array}{c}\text { Cherokee } \\
\text { Park } \\
\text { (CP) }\end{array}$ & $\begin{array}{l}\text { Iroquois } \\
\text { Park (IP) }\end{array}$ & $\begin{array}{c}\text { Jefferson } \\
\text { Mem- } \\
\text { orial } \\
\text { Forest } \\
\text { (JMF) }\end{array}$ & $\begin{array}{c}\text { Horner } \\
\text { Preserve } \\
\text { (HP) }\end{array}$ & $\begin{array}{c}\text { Mt. St. } \\
\text { Francis } \\
\text { Seminary } \\
\text { (MSF) }\end{array}$ & $\begin{array}{l}\text { Charles- } \\
\text { town } \\
\text { State } \\
\text { Park } \\
\text { (CSP) }\end{array}$ & $\begin{array}{l}\text { Lapping } \\
\text { Park } \\
\text { (LP) }\end{array}$ & $\begin{array}{c}\text { McNeely } \\
\text { Lake } \\
\text { Park } \\
\text { (MP) }\end{array}$ & $\begin{array}{c}\text { Horner } \\
\text { Preserve } \\
(\text { L. } \\
\text { maackii) } \\
\text { (HPH) }\end{array}$ & $\begin{array}{c}\text { Black- } \\
\text { acre } \\
\text { Nature } \\
\text { Preserve } \\
\text { (BA) }\end{array}$ & $\begin{array}{c}\text { Charles- } \\
\text { town } \\
\text { State } \\
\text { Park }(L . \\
\text { maackii) } \\
\text { (CSPH) }\end{array}$ & $\begin{array}{c}\text { Joe } \\
\text { Creason } \\
(\text { JC) }\end{array}$ & $\begin{array}{l}\text { E.P. } \\
\text { 'Tom' } \\
\text { Sawyer } \\
\text { (TS) }\end{array}$ \\
\hline $\begin{array}{l}\text { Anth- } \\
\text { ropo- } \\
\text { genic } \\
\text { Index }\end{array}$ & 37 & 38 & 15 & 2 & 1 & 0 & 22 & 19 & 1 & 16 & 0 & 28 & 16 \\
\hline $\begin{array}{c}\% \\
\text { Honey- } \\
\text { suckle } \\
\text { cover }\end{array}$ & 0.00 & 0.00 & 0.00 & 0.00 & 0.00 & 0.75 & 0.95 & 10.30 & 13.90 & 18.43 & 28.98 & 43.20 & 50.05 \\
\hline $\begin{array}{l}\text { Mean } \\
\text { tree ht. }\end{array}$ & 13.60 & 10.37 & 11.85 & 14.67 & 12.27 & 10.24 & 15.04 & 7.36 & 7.71 & 9.39 & 8.40 & 7.48 & 9.44 \\
\hline $\begin{array}{c}\text { Genus } \\
\text { with } \\
\text { highest } \\
\% \\
\text { cover }\end{array}$ & $\begin{array}{l}\text { maple } \\
(\text { Acer }) \\
100.01\end{array}$ & $\begin{array}{c}\text { maple } \\
(\text { Acer }) \\
59.38\end{array}$ & $\begin{array}{c}\text { oak } \\
\text { (Quercus) } \\
62.65\end{array}$ & $\begin{array}{c}\text { maple } \\
\text { (Acer) } \\
101.7\end{array}$ & $\begin{array}{l}\text { maple } \\
\text { (Acer) } \\
74.30\end{array}$ & $\begin{array}{l}\text { maple } \\
\text { (Acer) } \\
73.38\end{array}$ & $\begin{array}{l}\text { maple } \\
\text { (Acer) } \\
71.58\end{array}$ & $\begin{array}{l}\text { cedar } \\
\text { (Juni- } \\
\text { perus }) \\
30.95\end{array}$ & $\begin{array}{l}\text { cedar } \\
(\text { Juni- } \\
\text { perus }) \\
30.25\end{array}$ & $\begin{array}{c}\text { maple } \\
(\text { Acer }) \\
51.68\end{array}$ & $\begin{array}{c}\text { maple } \\
(\text { Acer }) \\
46.85\end{array}$ & $\begin{array}{l}\text { honey- } \\
\text { suckle } \\
\text { (Loni- } \\
\text { cera) } \\
43.20\end{array}$ & $\begin{array}{l}\text { honey- } \\
\text { suckle } \\
\text { (Loni- } \\
\text { cera) } \\
50.05\end{array}$ \\
\hline $\begin{array}{c}\text { Genus } \\
\text { with } \\
\text { 2nd } \\
\text { highest } \\
\% \\
\text { cover }\end{array}$ & $\begin{array}{c}\text { ash } \\
\text { (Fraxi- } \\
\text { nus) } \\
23.98\end{array}$ & $\begin{array}{c}\text { oak } \\
(\text { Quer- } \\
\text { cus }) \\
50.63\end{array}$ & $\begin{array}{c}\text { maple } \\
\text { (Acer) } \\
13.83\end{array}$ & $\begin{array}{c}\text { ash } \\
\text { (Fraxi- } \\
\text { nus) } \\
37.75\end{array}$ & $\begin{array}{c}\text { ash } \\
\text { (Fraxi- } \\
\text { nus) } \\
28.58\end{array}$ & $\begin{array}{c}\text { ash } \\
\text { (Fraxi- } \\
\text { nus) } \\
23.98\end{array}$ & $\begin{array}{c}\text { spice- } \\
\text { bush } \\
(\text { Lindera) } \\
19.25\end{array}$ & $\begin{array}{c}\text { Oak } \\
\text { (Quercus) } \\
22.10\end{array}$ & $\begin{array}{l}\text { maple } \\
\text { (Acer) } \\
24.05\end{array}$ & $\begin{array}{c}\text { hickory } \\
\text { (Carya) } \\
25.93\end{array}$ & $\begin{array}{l}\text { honey- } \\
\text { suckle } \\
\text { (Loni- } \\
\text { cera) } \\
28.98\end{array}$ & $\begin{array}{c}\text { maple } \\
\text { (Acer) } \\
31.90\end{array}$ & $\begin{array}{c}\text { locust } \\
\text { (Robin- } \\
\text { ia) } 14.88\end{array}$ \\
\hline $\begin{array}{c}\text { Genus } \\
\text { with } \\
\text { 3rd } \\
\text { highest } \\
\% \\
\text { cover }\end{array}$ & $\begin{array}{c}\text { walnut } \\
\text { (Juglans) } \\
21.05\end{array}$ & $\begin{array}{c}\text { ash } \\
\text { (Fraxi- } \\
\text { nus) } \\
17.43\end{array}$ & $\begin{array}{c}\text { pine } \\
\text { (Pinus) } \\
11.58\end{array}$ & $\begin{array}{c}\text { walnut } \\
\text { (Juglans) } \\
7.13\end{array}$ & $\begin{array}{c}\text { oak } \\
(\text { Quer- } \\
\text { cus }) \\
24.50\end{array}$ & $\begin{array}{c}\text { oak } \\
(\text { Quer- } \\
\text { cus }) \\
22.00\end{array}$ & $\begin{array}{c}\text { beech } \\
\text { (Fagus) } \\
18.05\end{array}$ & $\begin{array}{c}\text { maple } \\
\text { (Acer) } \\
18.58\end{array}$ & $\begin{array}{c}\text { Osage } \\
\text { Orange } \\
(\text { Mac- } \\
\text { lura }) \\
16.98\end{array}$ & $\begin{array}{c}\text { oak } \\
(\text { Quer- } \\
\text { cus }) \\
24.35\end{array}$ & $\begin{array}{l}\text { cedar } \\
(\text { Juni- } \\
\text { perus }) \\
21.28\end{array}$ & $\begin{array}{c}\text { pawpaws } \\
\text { (Asimina) } \\
19.30\end{array}$ & $\begin{array}{c}\text { maple } \\
\text { (Acer) } \\
13.73\end{array}$ \\
\hline $\begin{array}{c}\text { Tree } \\
\text { diver- } \\
\text { sity } \\
\left(\mathbf{N}_{2}\right)\end{array}$ & 3.74 & 3.85 & 6.08 & 3.01 & 5.52 & 7.83 & 4.46 & 6.49 & 8.22 & 8.38 & 7.45 & 3.64 & 3.87 \\
\hline $\begin{array}{l}\text { Eleva- } \\
\text { tion } \\
(\mathbf{m})\end{array}$ & 164.60 & 221.0 & 216.1 & 228.0 & 274.8 & 171.1 & 136.7 & 192.3 & 188.7 & 224.4 & 199.1 & 168.3 & 226.3 \\
\hline
\end{tabular}




\begin{tabular}{|c|c|c|c|c|c|c|c|c|c|c|c|c|c|}
\hline $\begin{array}{l}\text { Forest } \\
\text { Stand }\end{array}$ & $\begin{array}{l}\text { Cherokee } \\
\text { Park } \\
\text { (CP) }\end{array}$ & $\begin{array}{l}\text { Iroquois } \\
\text { Park (IP) }\end{array}$ & $\begin{array}{c}\text { Jefferson } \\
\text { Mem- } \\
\text { orial } \\
\text { Forest } \\
\text { (JMF) }\end{array}$ & $\begin{array}{c}\text { Horner } \\
\text { Preserve } \\
\text { (HP) }\end{array}$ & $\begin{array}{c}\text { Mt. St. } \\
\text { Francis } \\
\text { Seminary } \\
\text { (MSF) }\end{array}$ & $\begin{array}{c}\text { Charles- } \\
\text { town } \\
\text { State } \\
\text { Park } \\
\text { (CSP) }\end{array}$ & $\begin{array}{l}\text { Lapping } \\
\text { Park } \\
\text { (LP) }\end{array}$ & $\begin{array}{c}\text { McNeely } \\
\text { Lake } \\
\text { Park } \\
\text { (MP) }\end{array}$ & $\begin{array}{c}\text { Horner } \\
\text { Preserve } \\
(\text { L. } \\
\text { maackii) } \\
\text { (HPH) }\end{array}$ & $\begin{array}{l}\text { Black- } \\
\text { acre } \\
\text { Nature } \\
\text { Preserve } \\
\text { (BA) }\end{array}$ & $\begin{array}{c}\text { Charles- } \\
\text { town } \\
\text { State } \\
\text { Park }(\text { L. } \\
\text { maackii) } \\
\text { (CSPH) } \\
\end{array}$ & $\begin{array}{c}\text { Joe } \\
\text { Creason } \\
(\text { JC) }\end{array}$ & $\begin{array}{c}\text { E.P. } \\
\text { 'Tom' } \\
\text { Sawyer } \\
\text { (TS) }\end{array}$ \\
\hline $\begin{array}{c}\% \\
\text { Can- } \\
\text { opy } \\
\text { cover }\end{array}$ & 86.07 & 89.29 & 72.24 & 81.79 & 81.33 & 77.61 & 86.43 & 73.81 & 75.90 & 77.06 & 81.57 & 82.38 & 78.97 \\
\hline $\begin{array}{c}\% \\
\text { Under- } \\
\text { story } \\
\text { cover }\end{array}$ & 7.20 & 14.33 & 3.75 & 3.50 & 13.00 & 14.63 & 16.75 & 17.88 & 23.50 & 16.88 & 15.63 & 32.15 & 15.88 \\
\hline $\begin{array}{c}\% \\
\text { Bare- } \\
\text { ground }\end{array}$ & 52.24 & 68.50 & 68.21 & 83.44 & 78.32 & 83.47 & 38.97 & 48.96 & 80.67 & 75.21 & 70.73 & 56.58 & 39.91 \\
\hline
\end{tabular}




\section{Discussion}

\section{Blackacre State Nature Preserve (honeysuckle)}

The Blackacre State Nature Preserve (BA) has an AI value of 16, which was also the median score across all stands and was expected given its location within a suburban context. The preserve is surrounded primarily by residential areas (house subdivisions). The high Simpson's diversity $\mathrm{N}_{2}$ value (8.38) for trees is a reflection of the land preservation history and late successional stage (mature, large-boled trees). The mean vegetation height at the preserve was $9.39 \mathrm{~m}$, placing it close to the median height across all 13 stands (median height $=10.24 \mathrm{~m}$ ). It was, however, one of the taller stands with a high relative cover of honeysuckle, as stands with high honeysuckle cover tended to be shorter than those with low honeysuckle cover. This low mean tree height indicates more shrub and sub-canopy layer vegetation compared to upper canopy; percent understory cover was $16.88 \%$ which is an intermediate amount of understory cover relative to the other stands. Percent canopy cover was relatively low $(77.06 \%)$. The percent bare ground metric was $75.21 \%$, among the highest of all the forest stands. A small intermittent stream (a tributary of the nearby Floyd's Fork stream) runs through the area of the preserve and occasional flooding of the stream could contribute to the high percentage of bare ground. 


\section{Cherokee Park (no honeysuckle)}

The trail I utilized within Cherokee Park (CP) had undergone honeysuckle removal efforts and had $0.00 \%$ honeysuckle cover at the time of the study. Given its urban location near the center of the Greater Louisville Metropolitan Area, it is no surprise that Cherokee Park's AI score was 37, which is the second highest of all 13 stands. The forest had a $\mathrm{N}_{2}$ value of 3.74 (equivalent to 3.74 tree genera of equal importance), which is slightly below the average across all stands of 5.58. The relatively low diversity indices for this park may be the result of tornado damage in the 1970s decreasing the number of large native trees and allowing the invasion by exotic shrubs and vines. Maples had the largest cover in Cherokee Park (100.01\%) indicating a high degree of overlapping maple cover along the transects. The mean tree height of the trees surveyed in $\mathrm{CP}$ was $13.6 \mathrm{~m}$, making $\mathrm{CP}$ the third tallest stand. Similar to other stands with low percent honeysuckle cover, the high mean height of trees in $\mathrm{CP}$ indicates a higher abundance of sub-canopy and canopy trees relative to shrubs; the low percent understory cover of $7.20 \%$ supports this finding. Cherokee Park had a moderate amount of bare ground at $52.24 \%$

\section{Charlestown State Park (honeysuckle and no honeysuckle)}

Both high and low honeysuckle density transects at Charlestown State Park (CSP and $\mathrm{CSPH}$ ) had AI scores of 0 , indicating no man-made structures were visible along the two trails I utilized. The relatively low mean tree height of both stands indicates a higher abundance of sub-canopy trees and shrubs compared to canopy trees. The Simpson's $\mathrm{N}_{2}$ 
of CSP (7.83) was relatively high compared to all stands. The tree diversity at CSPH was slightly less than that of CSP, with a $\mathrm{N}_{2}$ of 7.45. Charlestown State Park is among the most diverse forest stands within the study. The area of the park invaded with honeysuckle, CSPH, has a higher percent understory cover $(15.63 \%)$ relative to the uninvaded area (CSP, 14.63\%).

\section{Horner Nature Preserve (honeysuckle and no honeysuckle)}

The mean tree height of HPH was relatively short $(7.71 \mathrm{~m})$ due to a higher abundance of sub-canopy trees and shrubs relative to upper canopy trees; percent understory cover of HPH was $23.5 \%$. Percent canopy cover was relatively low (75.8\%), and the percent of bare ground coverage was relatively high $(80.67 \%)$. HPH had a relatively high $\mathrm{N}_{2}$ value of 8.22 . The first site $(\mathrm{HPH})$ starkly contrasts the area of the preserve with $0.00 \%$ honeysuckle cover (denoted HP) which had the lowest $\mathrm{N}_{2}$ value recorded among the stands (3.01). The trail at HP had a mean tree height of $14.67 \mathrm{~m}$, which was the second tallest of all 13 stands, and a coinciding low percent understory cover of $3.50 \%$. Percent canopy cover of HP was high at $81.79 \%$. The percent bare ground value was high $(83.44 \%)$, potentially because the dense canopy cover restricts light penetration to the forest floor. HP had a high abundance of large old growth, upper canopy trees. The AI metrics for both HP and HPH were low at 2 and 1, respectively. The preserve is relatively rural and minimally anthropogenically influenced, with much of the surrounding area consisting of agricultural fields. 


\section{Iroquois Park (no honeysuckle)}

Considering its location, Iroquois Park had the highest anthropogenic index score out of all the stands $(\mathrm{AI}=38)$. Exotic invaders, including Amur honeysuckle, had established themselves in areas of the park (personal observation). However the particular transect used in this study has $0.00 \%$ honeysuckle cover. The mean tree height at Iroquois Park was $10.37 \mathrm{~m}$, similar to the mean tree height across all stands (10.60 m). A relatively low mean tree height and $14.33 \%$ understory cover indicated that the park is mostly composed of shrubs and sub-canopy trees as opposed to upper canopy trees. Percent canopy cover was $89.29 \%$, which is the highest across all stands. Percent bare ground of $68.50 \%$ was near the overall mean of $65.02 \%$. The park had relatively low tree diversity with a $\mathrm{N}_{2}$ value of 3.85 .

\section{Joe Creason Park (honeysuckle)}

The high percent understory cover of $32.15 \%$, which was the highest of all the study stands, contributed to the low mean vegetation height of Joe Creason of $7.48 \mathrm{~m}$. The high abundance of honeysuckle contributes to the low mean tree height and dominant shrub and sub-canopy layers in contrast to the upper canopy. Percent canopy cover was $82.38 \%$ and percent bare ground was $56.58 \%$, which was relatively low. It had the second lowest $\mathrm{N}_{2}$ value (3.64), and the third highest AI score (28). 


\section{Jefferson Memorial Forest (no honeysuckle)}

The AI of the forest was 15 , which is close to the median AI across all 13 stands (median $\mathrm{AI}=16$ ). The $\mathrm{N}_{2}$ value for Jefferson Memorial Forest was 6.08 and was close to the median $\mathrm{N}_{2}$ value across all stands (median $\mathrm{N}_{2}=5.52$ ). Mean tree height was $11.85 \mathrm{~m}$, which is slightly greater than the mean tree height of all stands $(10.60 \mathrm{~m})$. The forest appears to consist mostly of sub-canopy and upper canopy trees, rather than shrubs; percent understory cover was only $3.75 \%$. Percent canopy cover and bare ground were $72.24 \%$ and $68.21 \%$ respectively, which are moderate values compared to all stands.

\section{Lapping Park (no honeysuckle)}

The trees at Lapping Park were the tallest of all 13 stands $(15.4 \mathrm{~m})$ indicating the forest was mostly composed of large-boled, upper canopy trees; the percent canopy cover also was the highest measured (86.43\%). The park had a moderate percent understory cover of $16.75 \%$ and a low percent bare ground of $38.97 \%$. It had the fourth highest AI score of all the stands at 22; golf course fairways, fields and an interstate highway are near the hiking trail used in the study.

\section{McNeely Lake Park (honeysuckle)}

McNeely Lake Park had an AI score of 19, which is slightly higher than the median AI across all 13 stands (median AI $=16$ ). The urban park was heavily invaded by Amur honeysuckle (10.30\% cover), which in turn created a high relative percent 
understory cover of $17.88 \%$. Similar to other forest stands invaded with honeysuckle, McNeely had a low mean tree height of $7.36 \mathrm{~m}$, indicating it is mostly composed of shrubs and sub-canopy trees with relatively fewer tall upper canopy trees (thus creating a low percent canopy cover of $73.81 \%$ ). The percent bare ground was quite low (48.96\%). The $\mathrm{N}_{2}$ value of 6.49 was at the higher end of the range; tree diversity was relatively higher compared to other sites.

\section{Mount St. Francis Seminary (no honeysuckle)}

Mount St. Francis has a low AI of 1 which reflects the preservation of the sanctuary to maintain a site of little human impact. With a mean tree height of $12.27 \mathrm{~m}$, the fourth tallest of all the stands, Mount St. Francis contained mostly old-growth, upper canopy trees of a mature forest as opposed to younger sub-canopy trees and shrubs of a younger forest. The forest's older age was also suggested by the high percent canopy cover $(81.33 \%)$ and high percent bare ground cover $(78.32 \%)$. The percent understory cover of $13.00 \%$ was slightly less than the median cover across all stands (15.63\%). The $\mathrm{N}_{2}$ value of 5.52 was intermediate relative to the other stands.

\section{E.P. 'Tom' Sawyer State Park (honeysuckle)}

Despite a lot of man-made structures within the park, 'Tom' Sawyer Park (TS) had an AI score of 16, similar to that of BA. The stand had a mean tree height of $9.44 \mathrm{~m}$, indicating the park consists of more shrubs and sub-canopy trees than upper canopy trees. 
Tom Sawyer Park had the highest percent honeysuckle cover of all 13 stands. Lonicera makes up $50.05 \%$ of the cover, which more than likely attributed to both the low mean tree height and percent understory cover (15.88\%). Honeysuckle exceedingly dominates the park because the tree genera with next highest percent coverage were locust (black locust, Robinia Linnaeus) at only $14.88 \%$ and maples at $13.73 \%$. Percent canopy cover (78.97\%) and percent bare ground (39.91\%) were both relatively low. Similar to the other forest stand with very high percent honeysuckle cover (Joe Creason Park), Tom Sawyer State Park had a low tree diversity $\mathrm{N}_{2}$ value of 3.87 . 


\section{CHAPTER 5: OVERALL IMPACT OF HONEYSUCKLE AND FOREST STAND COMPOSITION ON OVERALL BIRD DIVERSITY}

The first hypothesis was Amur honeysuckle density impacts bird diversity. I predicted honeysuckle density negatively impacts bird diversity across all seasons. Second, regardless of the impact (if any) by Amur honeysuckle upon bird diversity, I wished to determine whether differences in other environmental characteristics of the forest stands had any impact on the avian community. Changes in tree diversity of the forest stands may influence bird diversity in a variety of ways; for example, increased tree diversity may increase bird diversity via increasing the variety of possible food sources (fruits) that would be preferred by different birds. Other compositional aspects of forest stands (such as percent canopy cover, mean tree height, and anthropogenic influence) may have more of an influence on bird diversity than tree diversity. In particular, based on the results of earlier studies, I predicted that increased canopy cover and mean tree height would increase bird diversity.

\section{Statistical Analysis}

Bird counts and species richness at every forest stand were determined for each season in both 2013 (year 1) and 2014 (year 2). The bird surveys were first examined and several bird groups subsequently were eliminated from the analysis. Waterfowl and shorebird observations were eliminated from the data set, due to 1) their rare occurrence 
and 2) the absence of a permanent water source from some forest stands. Alpha diversity was investigated by using Shannon diversity index $\left(\mathrm{H}^{\prime}, \mathrm{H}^{\prime}=-\Sigma\left(p_{i} \ln p_{i}\right)\right)$ and Simpson diversity index ( $\left.\mathrm{D}, \mathrm{D}=\Sigma\left(p_{i}\right)^{2}\right)$. The Simpson diversity index ranges from 0 to 1 , with 0 being the most diverse and 1 being the least diverse. The Shannon index assumes all species are represented in a sample therefore giving more weight to rare species relative to Simpson's index, which gives more weight to dominant or common species (Heip et al. 1998). Use of both diversity indices rather than one allows for an improved interpretation of habitat diversity while providing some measure of the relative dominance of both rare and common species. $\mathrm{N}_{1}$ and $\mathrm{N}_{2}$ values subsequently were calculated from these indices: $\mathrm{N}_{1}=\mathrm{e}^{\mathrm{H}}$ and $\mathrm{N}_{2}=1 / \mathrm{D}$. The $\mathrm{N}_{1}$ and $\mathrm{N}_{2}$ indices generate values that are equivalent to the number of species that would be found in a stand if all species were equally common, which allows for a more direct comparison to species richness (Hill 1973; Krebs 1999). The minimum value for both Shannon's $N_{1}$ and Simpson's $\mathrm{N}_{2}$ is 1 , and the maximum values are equal to species richness $\mathrm{S}$ (Heip et al. 1998). Bird alpha diversity metrics were calculated for every season within the two study years.

In order to determine whether compositional aspects of the thirteen forest stands influenced bird diversity, a multiple regression was performed using PROC MIXED of SAS (Goodnight 2015). The explanatory variables representing every tree stand were as follows: percent honeysuckle cover, percent canopy cover, mean tree height, anthropogenic index (AI), and tree diversity (using Simpson's $\mathrm{N}_{2}$ ). Due to high collinearity between the various measures of alpha diversity, Simpson's $\mathrm{N}_{2}$ was selected as the only alpha diversity metric used as the response variable in multiple regression 
analysis. Due to the seasonal variation of honeysuckle and canopy cover, season was treated as an explanatory variable and year as a random variable. The variables were standardized to allow for comparisons between parameter coefficients. The Variance Inflation Factor (VIF) of each explanatory variable was assessed to ensure collinearity did not exist among the variables. The VIF of every variable was below 5, indicating there was no high collinearity among explanatory variables. Two-way interactions were added to the model using forward inclusion to determine whether any interactions between any two explanatory variables significantly influenced bird diversity. The interactions of all explanatory variables and season were tested in order to determine whether effects differed seasonally. Next, backward elimination of explanatory variables with insignificant effects to bird diversity was performed until removal of effects caused a decrease in the significance of significant effects.

\section{Results}

Tables of bird alpha diversity indices for every year-season combination are located in Appendix 3 on page 136-143. A table of the results of the multiple regression analysis is located in Appendix 4 on page 144.

In the initial analysis, none of the interactions between the explanatory variables and season significantly explained bird diversity and the explanatory variable season was the least significant. Therefore, the variable season and all the interactions with season were eliminated from the analysis. Ultimately, backwards elimination of insignificant effects to bird diversity left the model with two significant explanatory variables 
(honeysuckle cover and AI, explained below) and only one positive significant interaction (between tree diversity and mean tree height, $\mathrm{p}=0.0002$ ); the interpretation of this interaction is that the effect of tree diversity on bird diversity depended on mean tree height and vice versa. Spring and summer showed the highest effect of the interaction between tree stand diversity and mean tree height. However, the effects of neither tree stand diversity nor mean tree height on bird diversity were significant $(p=0.6086$ and $p$ $=0.1385$, respectively), although both effects were positive.

Percent honeysuckle cover had a significantly negative impact on bird diversity ( $\mathrm{p}$ $=0.0208)$, particularly in the spring, but there was no significant honeysuckle cover by season interaction. The correlation coefficients were low in most seasons except in the spring (Figure 2). 


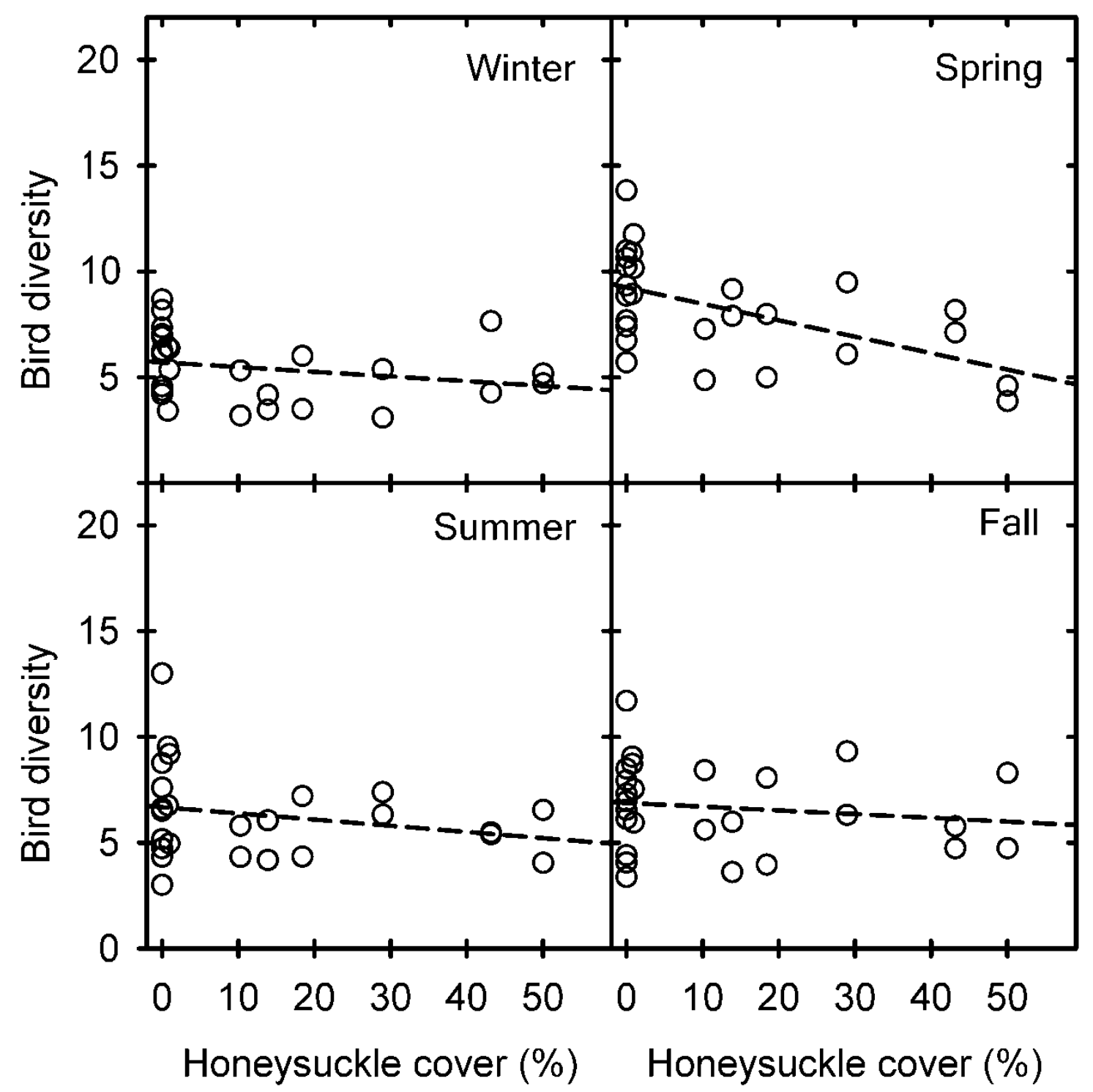

Figure 2. Relationship between honeysuckle cover and bird diversity (Simpson's Diversity $\mathrm{N}_{2}$ ) for all 13 forest stands in each season with years combined. Winter $\mathrm{r}^{2}=$ 0.0579; Spring $r^{2}=0.3050$; Summer $r^{2}=0.0554$; Fall $r^{2}=0.0219$. 
Percent canopy cover exerted a small positive impact on bird diversity (as canopy cover increased, bird diversity increased), but it was not significant $(\mathrm{p}=0.4285)$. In all seasons, the correlation coefficients were low (Figure 3).

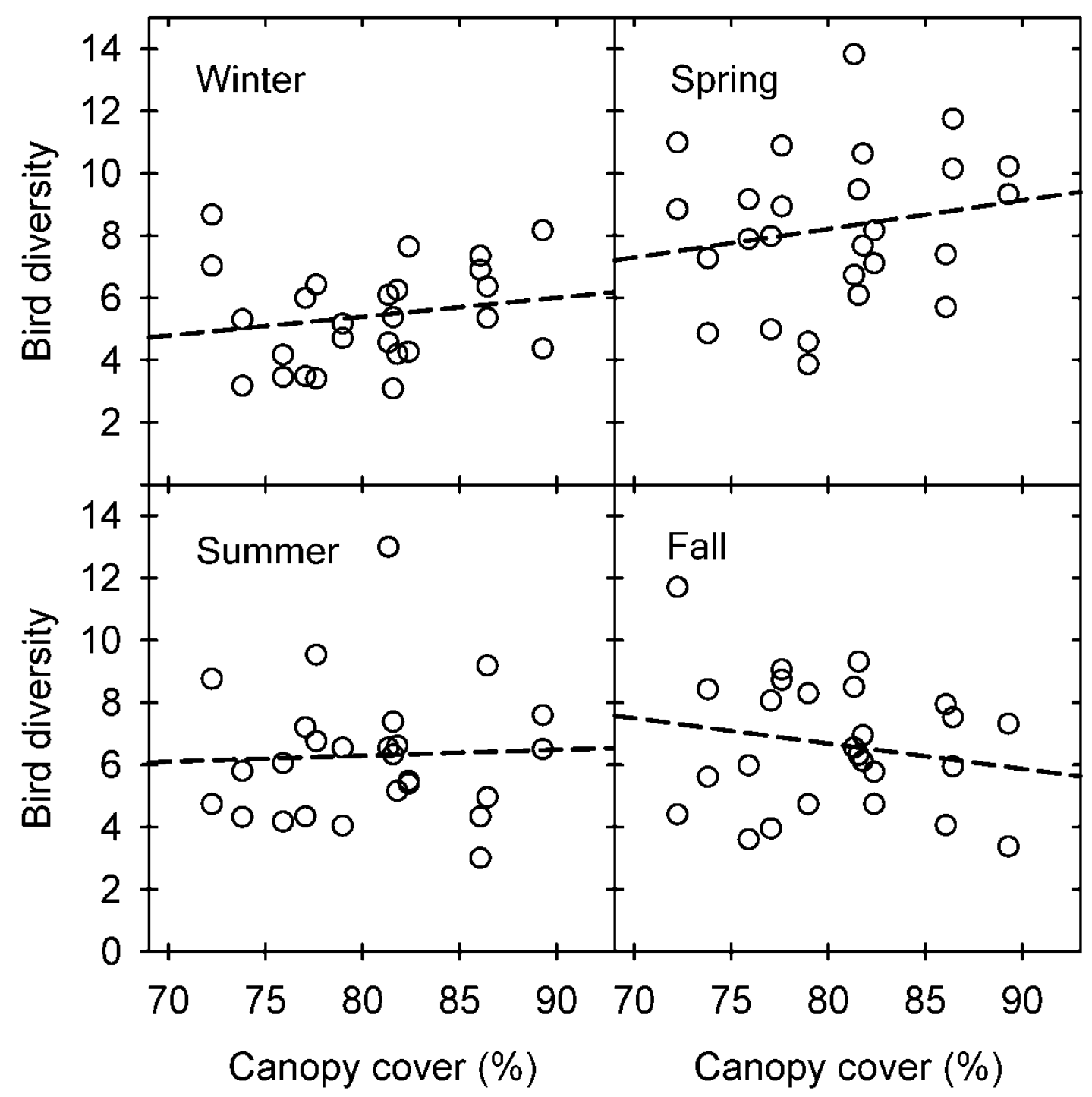

Figure 3. Relationship between canopy cover and bird diversity (Simpson's Diversity $\mathrm{N}_{2}$ ) for all 13 forest stands in each season with years combined. Winter $\mathrm{r}^{2}=0.0356$; Spring $\mathrm{r}^{2}$ $=0.0351 ;$ Summer $r^{2}=0.0020 ;$ Fall $r^{2}=0.0382$. 
Mean tree height did not significantly impact bird diversity $(\mathrm{p}=0.1385)$ but the impact was positive (as mean tree height increased, bird diversity increased). The correlation coefficients were low in the summer and fall and slightly higher in the winter and spring (Figure 4).

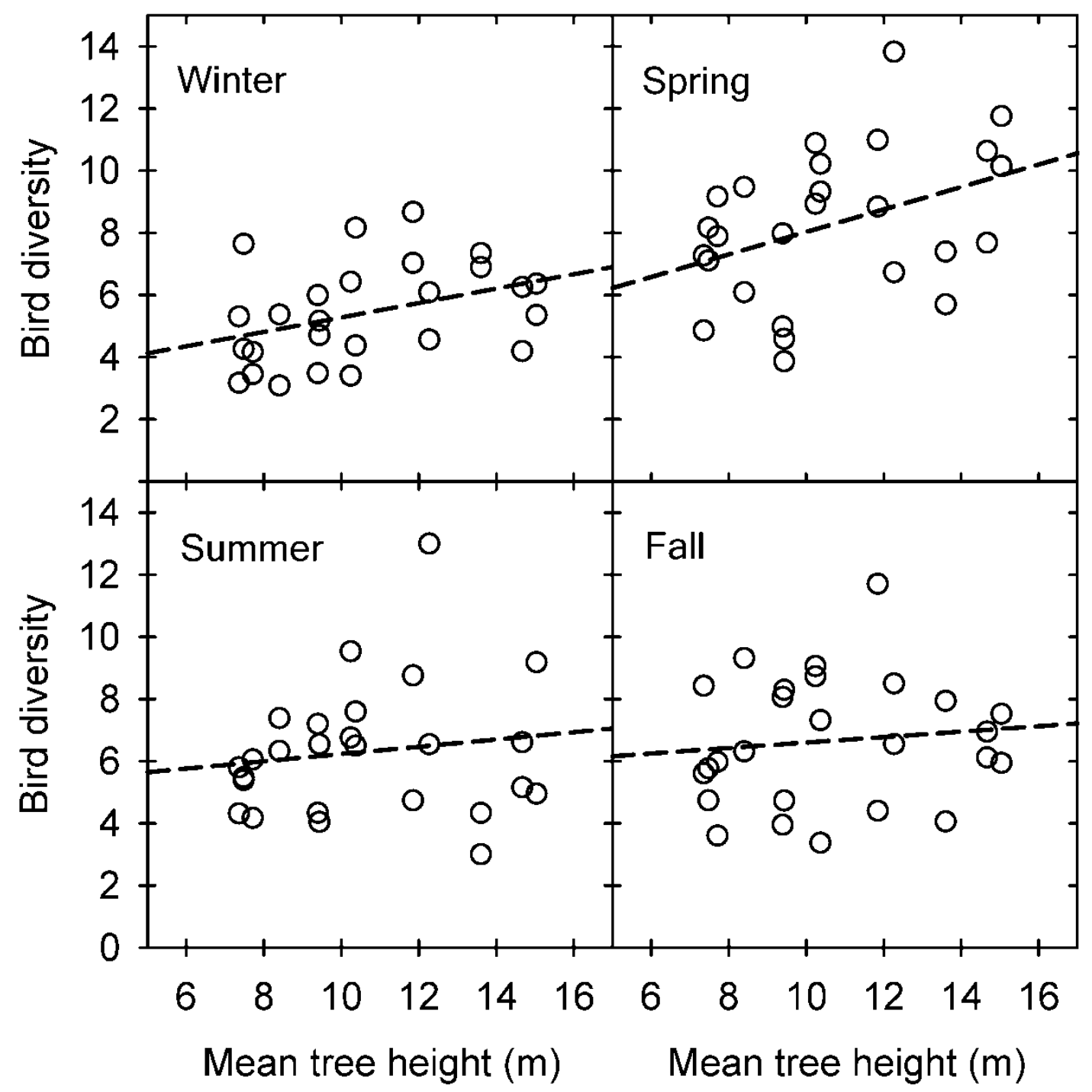

Figure 4. Relationship between mean tree height and bird diversity (Simpson's Diversity $\mathrm{N}_{2}$ ) for all 13 forest stands in each season with years combined. Winter $\mathrm{r}^{2}=0.1444$; Spring $r^{2}=0.1531$; Summer $r^{2}=0.0208$; Fall $r^{2}=0.0125$. 
The impact of tree stand diversity on bird diversity was not significant $(\mathrm{p}=$ 0.6086) but was slightly positive in two seasons. The correlation coefficients were all low (Figure 5).

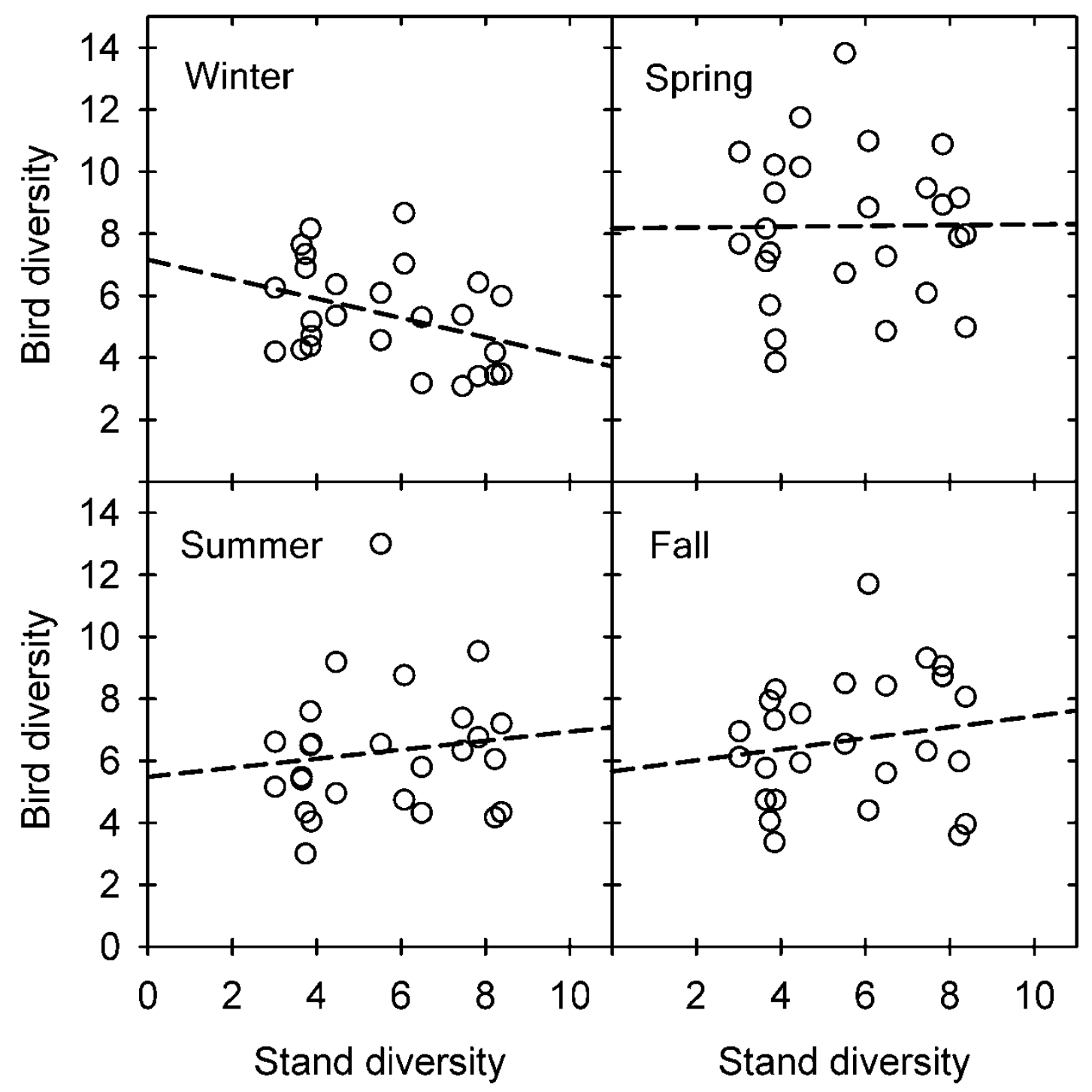

Figure 5. Relationship between tree stand diversity (Simpson's Diversity $\mathrm{N}_{2}$ ) and bird diversity (Simpson's Diversity $\mathrm{N}_{2}$ ) for all 13 forest stands in each season with years combined. Winter $r^{2}=0.1388$; Spring $r^{2}=0.0001$; Summer $r^{2}=0.0169$; Fall $r^{2}=0.0271$. 
AI significantly influenced bird diversity negatively $(\mathrm{p}=0.0439)$. As the amount of human impacts increased in the area around the stand, bird diversity generally declined. Spring and summer showed the highest positive association between AI and bird diversity. The relationship was actually negative in the winter (Figure 6).

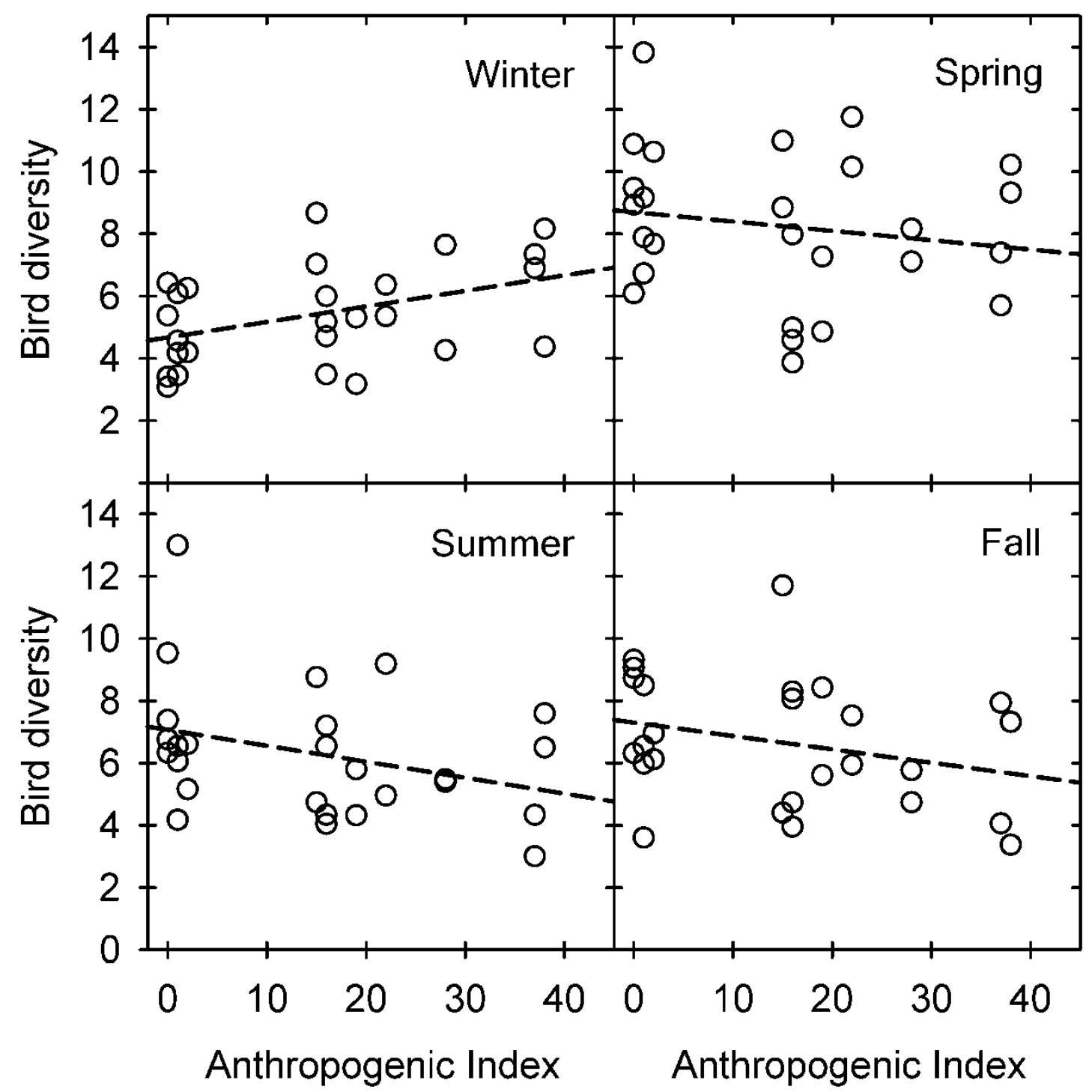

Figure 6. Relationship between anthropogenic index and bird diversity (Simpson's Diversity $\mathrm{N}_{2}$ ) for all 13 forest stands in each season with years combined. Winter $\mathrm{r}^{2}=$ 0.1764; Spring $r^{2}=0.0278$; Summer $r^{2}=0.1046$; Fall $r^{2}=0.0783$. 


\section{CHAPTER 6: IMPACT OF HONEYSUCKLE ON SPECIFIC BIRD TAXA}

If honeysuckle impacts avian diversity, what fluctuations in the bird communities based on honeysuckle are responsible for the change? First, the abundance of understory bird species (e.g., cardinals, sparrows, and thrushes) increased with increased honeysuckle density, especially in the spring and summer, due to their use of bush honeysuckle as protective cover or feeding sites. Second, I predicted that the abundance of mid to upper canopy birds (e.g., Eastern wood-pewees and other flycatchers, parids, warblers, and woodpeckers) will be negatively associated with honeysuckle density because habitat with dense honeysuckle will have less foliage height diversity. Third, the abundance of the American robin, a common facultative frugivore, will be positively influenced by honeysuckle density during the fall months, when honeysuckle shrubs produce mass quantities of fruit in the fall.

\section{Statistical Analysis}

In order to assess the data collected at each of the 13 research sites, I performed a nonmetric multidimensional scaling (NMDS) ordination, using the software program PCORD (McCune and Mefford 2006). The goal was to generate coordinates unique and representative to each stand in order to compare effects of forest composition and honeysuckle density to bird abundance using generalized regressions. 
Trees at each forest stand were categorized by genus and the percent cover of each genus, also referred to as the absolute proportion or importance value of each genus, was determined based on the total transect length (400 m). Forty-four different genera were observed across all stands. For the NMDS, the absolute proportion of Lonicera spp. was excluded in order to utilize the proportion of the shrub species in each forest stand as an independent study variable. The first matrix for the nonmetric scaling ordination consisted of the proportion of the pertinent forty-three genera at each stand. For the second matrix, seven attributes of each stand were included: the mean elevation (m); mean percent bare ground including rock, woody, and leafy debris (in percent); mean percent open sky (in percent), percent of understory coverage ( 1 to 2 meter vegetation) out of the total 400 meters surveyed (in percent); mean tree height (m); standard deviation of mean tree height (m); and AI score (number between 0 and 100).

For the NMDS analysis, the Sorensen (Bray-Curtis) Distance Measure was selected. The selected parameter values for the ordination procedure were as follows: 3 axes (k), 50 runs with real data, a criterion stability of $0.00001,30$ iterations to evaluate stability, 500 maximum iterations, selection to step down in dimensionality, and an initial step length of 0.20 . The source of the starting coordinates was provided from a random number generator. The only output option selected was plot stress vs. iterations (McCune and Mefford 2006). 


\section{Forest Stand Analyses}

Tables with information used for the first and second matrix in the NMDS of the forest stands are located in the Appendix 5 and Appendix 6 on pages 145-152.

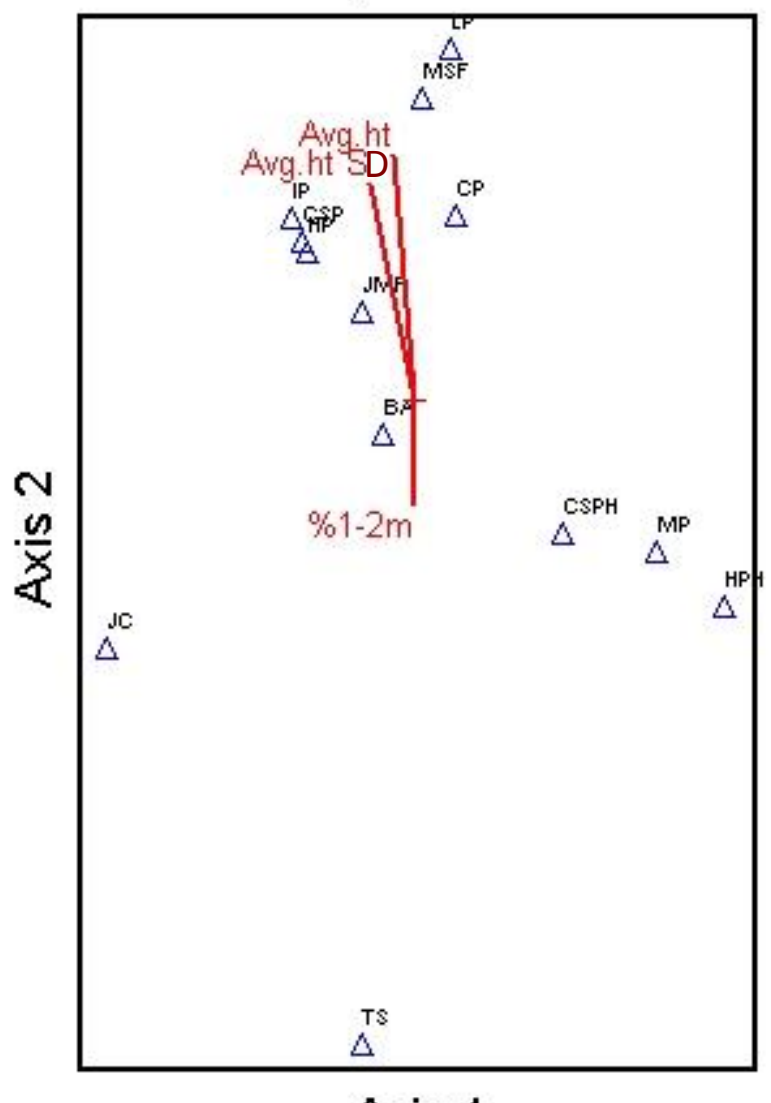

\section{Axis 1}

Figure 7: Two-dimensional (2D) simple scatter plot of the 13 forest stands according to the absolute proportion (importance value) of each tree genus, elevation, percent open sky, percent bare ground, mean tree height, standard deviation of mean tree height, percent understory cover, and anthropogenic index score. Only three variables were significant: average height, average height variability, and understory cover (1 to 2 $\mathrm{m})$. 
Coordinates of the 3 axes indicating the location of each forest stand within the NMDS ordination are in Appendix 7 on page 153. Three variables helped explain the resultant orientation of the stands in the 2D scatter plot; these variables were mean tree height, mean tree height standard deviation, and percent of 1 to $2 \mathrm{~m}$ understory cover. The remaining four variables (that were not significant factors in the ordination) were percent open sky, AI, percent bare ground, and elevation. The variation in Axis 2 was explained by mean tree height, mean tree height standard, and percent understory cover. Forest stands clustered at the top of Axis 2 had higher mean tree heights and lower percent understory cover while stands clustered towards the middle and bottom of Axis 2 had lower mean tree heights and higher percent understory cover. The variation in Axis 2 was also explained by the variation in tree genera; stands in which maple was very abundant are clustered toward the top of the figure. Towards the center of axis 2 , maples were still abundant but not as abundant as in those stands clustered towards the top; Eastern red cedars were abundant in these stands. The variation in Axis 1 was explained by the second and third most abundant tree genera; stands clustered in the center of axis 1 contained large proportions of maples, oaks, and ashes. Stands located on the end of either axis 1 or 2 differed considerably in their composition of dominant tree genera compared to the other forest stands (Joe Creason Park, Horner Preserve with honeysuckle, Lapping Park, and E.P. 'Tom' Sawyer). The variation in Axis 3 was explained by mean tree height, mean tree height standard deviation, and percent open sky; forest stands with less open (more closed) canopies and higher mean tree heights were located at one end of Axis 3 while stands with more open canopies and lower mean tree heights were located at the other end of Axis 3. Forest stands with low percent 
honeysuckle cover were explained by decreasing percent of 1 to $2 \mathrm{~m}$ understory coverage, increasing mean tree height, and lower percentages of open sky. Stands with low percent honeysuckle cover were located above the origin on the ordination. Stands with higher percent cover of honeysuckle were explained by increasing percent of 1 to 2 meter understory coverage, decreasing mean tree height, and higher percentages of open sky. Forest stands with relatively high percent honeysuckle cover were located below the origin on the ordination. The two stands in which Lonicera was the most abundant plant (Joe Creason Park and E.P. 'Tom' Sawyer Park) are positioned the farthest away from the other stands on both axes.

\section{Bird Analyses}

For each of the top ten most common bird species [Northern cardinal, American robin, Carolina chickadee, Tufted titmouse, Carolina wren, Eastern towhee, red-bellied woodpecker, blue jay, downy woodpecker, white-breasted nuthatch] and bird families [thrushes, sparrows, parids, woodpeckers, warblers, and flycatchers], I performed regression analyses of their abundances on several possible explanatory variables, including honeysuckle cover. I used a generalized Poisson regression generated by PROC GLIMMIX of SAS (Goodnight 2015). The percent honeysuckle cover of each stand and the combination of axes coordinates for each stand $\left(\mathrm{A}_{1}, \mathrm{~A}_{2}\right.$, and $\mathrm{A}_{3}$, obtained from the NMDS ordination and describing information about each of the thirteen stands) were included to determine whether bird taxa were influenced either by percent honeysuckle cover, or by compositional components of the forest stands other than 
honeysuckle, or by an interaction between honeysuckle abundance and forest stand composition. Analyses were performed by season in both study years so that effects were not overlooked by grouping years together.

Explanatory variables for the analysis of mechanisms influencing bird diversity were percent cover of Lonicera species, the three axis coordinates $\left(\mathrm{A}_{1}, \mathrm{~A}_{2}\right.$, and $\left.\mathrm{A}_{3}\right)$ for all 13 forest stands obtained from the NMDS, and interactions between these explanatory variables. Response variables were bird species or bird families. Season and year were treated as random effects and percent honeysuckle cover, the ordination axes, and interactions between them were treated as fixed effects. To lower the over-dispersion effect, the dispersion parameter (phi), was added to the model. Only models with a dispersion parameter of less than 2 were considered acceptable. The Poisson distribution was used, unless the dispersion parameter was 2 or greater for all models of effects to a bird species or family, which occurred for three birds (Northern cardinals, American robins, and Eastern towhees) and for two families (thrushes and sparrows). In those cases, the Poisson distribution was replaced by the less conservative negative binomial distribution. Akaike Information Criterion (AIC) was used to determine which model best fit the data; the model with the lowest AIC represents the model with the least amount of information lost during data processing (Goodnight 2015). The Variance Inflation Factor (VIF) of each explanatory variable used in the model was inspected for collinearity and models were not used if VIFs were equal to or greater than 5 (Goodnight 2015). The False Discovery Rate (FDR) method was used to adjust for multiple testing; the FDR pvalue was used to limit the number of false discoveries within significant results (Goodnight 2015). In fitting the models, almost all cases fit except a few cases; for those 
cases, the problem was resolved by analyzing the standardized variables rather than variables in their original scale. For each bird species, 3D plots were depicted to show the nature of the interaction between honeysuckle cover and one of the output axes, if present. Graphics were generated using the graphing functions of SAS (Goodnight 2015). Tables with p-values and FDR p-values for effects included in each model are included in Appendix 8 on pages 154-177.

\section{Results for specific species}

\section{Northern cardinals}

The most abundant bird species observed was the Northern cardinal, a typical understory species. The negative binomial distribution was used to avoid an overdispersion parameter of 2 or greater. The model with the lowest AIC value for the response variable (cardinal abundance) included honeysuckle, $\mathrm{A}_{1}$, and the interaction between honeysuckle and $A_{1}$. The abundance of cardinals was positively associated with percent honeysuckle cover across all seasons and trended towards significance in the spring of year $1(\mathrm{p}=0.0329 ;$ FDR $\mathrm{p}=0.1582)$, summer of year $1(\mathrm{p}=0.0179 ;$ FDR $\mathrm{p}=$ $0.1478)$ and the fall of year $2(\mathrm{p}=0.0257 ;$ FDR $\mathrm{p}=0.1540)($ Table 2$)$. The impact of honeysuckle density on cardinal abundance was significant in the summer of year $2(\mathrm{p}=$ $0.0015 ;$ FDR $p=0.0352$, Figure 8). No significant effects of $A_{1}$ or the interaction between honeysuckle and $A_{1}$ were apparent. Cardinals were the most common species observed in the family Cardinalidae, therefore their family was not analyzed separately. 
Table 2. Parameter estimates and significance of fixed effects included in the model on the abundance (number) of northern cardinals in all 13 forest stands within each season for both study years. The Xs represent effects which did not contribute to the model selected based on AIC. (Bolded values indicate p-value is significant, but the FDR p-value is not; * denotes FDR pvalue $\leq 0.05 ; * *$ denotes FDR p-value < 0.01; *** denotes FDR p-value <0.001).

\begin{tabular}{|c|c|c|c|c|c|c|c|c|}
\hline \multicolumn{10}{|c|}{ Abundance of Northern cardinals } \\
\hline & \multicolumn{9}{|c|}{ Year 1 Parameter Estimates } & \multicolumn{3}{c|}{ Year 2 Parameter Estimates } \\
\hline & Winter & Spring & Summer & Fall & Winter & Spring & Summer & Fall \\
\hline \% honeysuckle (HS) & 0.0842 & $\mathbf{0 . 3 2 4 8}$ & $\mathbf{0 . 3 0 3 0}$ & 0.1203 & 0.2857 & 0.1298 & $\mathbf{0 . 4 7 4 6 *}$ & $\mathbf{0 . 3 9 4 8}$ \\
\hline $\mathrm{A}_{1}$ (forest composition) & 0.0107 & 0.0788 & $\mathbf{0 . 3 4 2 0}$ & -0.3160 & -0.0815 & -0.3290 & 0.1048 & 0.1918 \\
\hline $\mathrm{A}_{2}$ (forest composition) & $\mathrm{X}$ & $\mathrm{X}$ & $\mathrm{X}$ & $\mathrm{X}$ & $\mathrm{X}$ & $\mathrm{X}$ & $\mathrm{X}$ & $\mathrm{X}$ \\
\hline $\mathrm{A}_{3}$ (forest composition) & $\mathrm{X}$ & $\mathrm{X}$ & $\mathrm{X}$ & $\mathrm{X}$ & $\mathrm{X}$ & $\mathrm{X}$ & $\mathrm{X}$ & $\mathrm{X}$ \\
\hline $\mathrm{HS}^{*} \mathrm{~A}_{1}$ & -0.2940 & -0.0625 & -0.1853 & 0.3552 & -0.2128 & -0.1513 & 0.1192 & -0.0105 \\
\hline $\mathrm{HS}^{*} \mathrm{~A}_{2}$ & $\mathrm{X}$ & $\mathrm{X}$ & $\mathrm{X}$ & $\mathrm{X}$ & $\mathrm{X}$ & $\mathrm{X}$ & $\mathrm{X}$ & $\mathrm{X}$ \\
\hline $\mathrm{HS}^{*} \mathrm{~A}_{3}$ & $\mathrm{X}$ & $\mathrm{X}$ & $\mathrm{X}$ & $\mathrm{X}$ & $\mathrm{X}$ & $\mathrm{X}$ & $\mathrm{X}$ & $\mathrm{X}$ \\
\hline
\end{tabular}




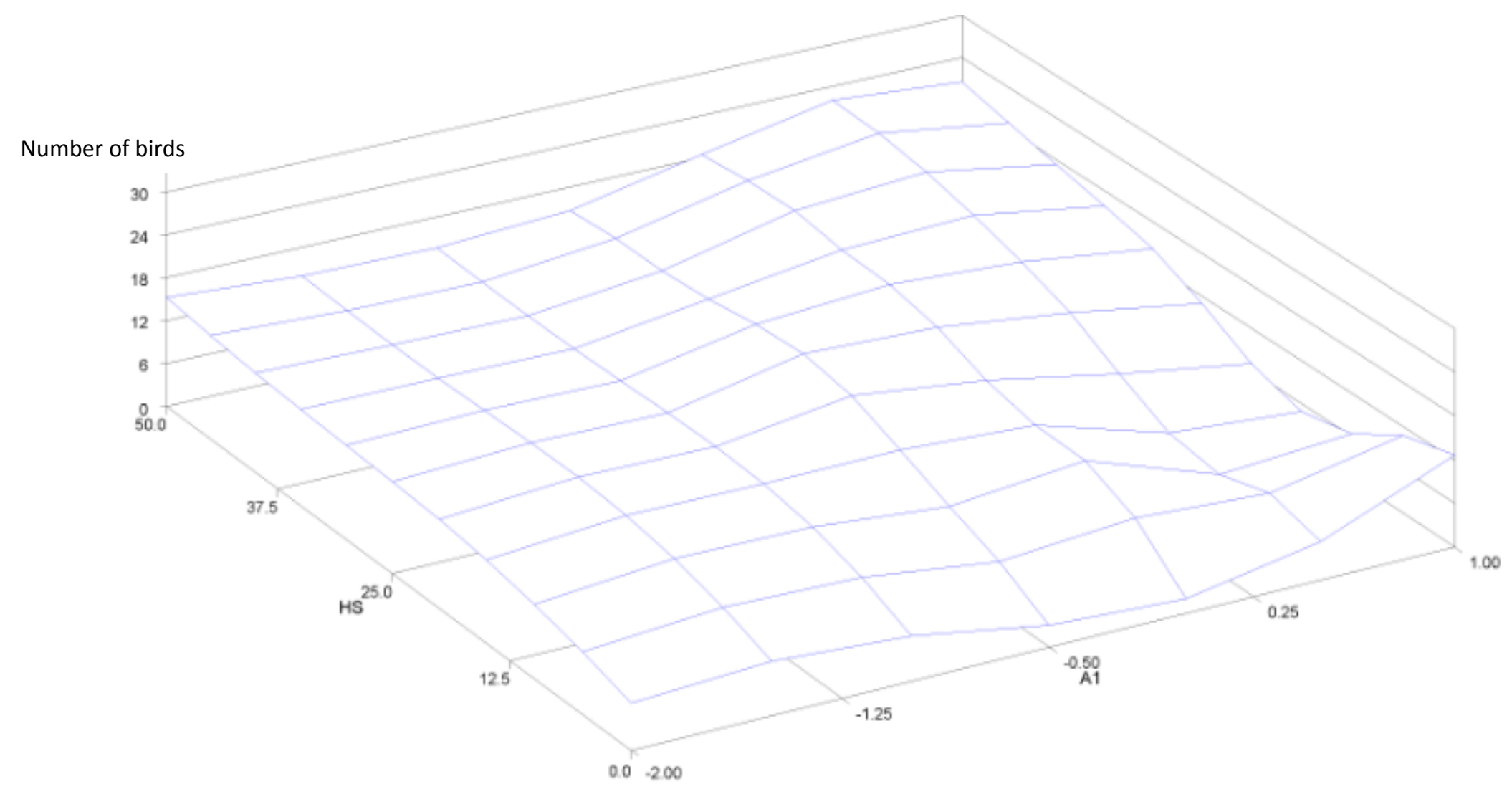

Figure 8. 3-dimensional depiction of the fixed effects included in the model for the abundance (number) of Northern cardinals in all 13 forest stands for the summer of year $2(p=0.0015$; FDR $p=0.0352)$. Effects of the interaction between percent honeysuckle cover (HS) and the forest composition representative axis 1 (A1) are represented by the fluctuations in the plane of the figure. 


\section{American robins}

The American robin, a known forager of honeysuckle fruit, was the second most abundant species. The negative binomial distribution was used, and the model with the lowest AIC value for the analysis of robin abundance included the effect of honeysuckle and $A_{3}$. As predicted, American robin abundance varied seasonally and yearly in response to honeysuckle density, but was positively influenced in the fall of both years (Table 3); the effect trended towards significance in the fall of year $1(\mathrm{p}=0.0154$; FDR $\mathrm{p}$ $=0.0821)$ and was significant in the fall of year $2(p=0.0039 ;$ FDR $p=0.0313$, Figure 9). Surprisingly, honeysuckle density negatively influenced robin abundance in the summer of both years, but not significantly. The stand compositional effect of $\mathrm{A}_{3}$ was significant in the summer of year $1(p=0.0005$; FDR $p=0.0082)$. 
Table 3. Parameter estimates and significance of fixed effects included in the model on the abundance (number) of American robins in all 13 forest stands within each season for both study years. The Xs represent effects which did not contribute to the model selected based on AIC. (Bolded values indicate $\mathrm{p}$-value is significant, but the FDR p-value is not; * denotes FDR pvalue $\leq 0.05 ; * *$ denotes FDR p-value < 0.01; *** denotes FDR p-value <0.001).

\begin{tabular}{|c|c|c|c|c|c|c|c|c|}
\hline \multicolumn{8}{|c|}{ Abundance of American robins } \\
\hline & \multicolumn{9}{|c|}{ Year 1 Parameter Estimates } & \multicolumn{3}{c|}{ Year 2 Parameter Estimates } \\
\hline & Winter & Spring & Summer & Fall & Winter & Spring & Summer & Fall \\
\hline \% honeysuckle (HS) & 0.0048 & 0.0038 & -0.0041 & $\mathbf{0 . 0 2 3 4}$ & -0.0222 & -0.0151 & -0.0107 & $\mathbf{0 . 0 4 3 7 2 *}$ \\
\hline $\mathrm{A}_{1}$ (forest composition) & $\mathrm{X}$ & $\mathrm{X}$ & $\mathrm{X}$ & $\mathrm{X}$ & $\mathrm{X}$ & $\mathrm{X}$ & $\mathrm{X}$ & $\mathrm{X}$ \\
\hline $\mathrm{A}_{2}$ (forest composition) & $\mathrm{X}$ & $\mathrm{X}$ & $\mathrm{X}$ & $\mathrm{X}$ & $\mathrm{X}$ & $\mathrm{X}$ & $\mathrm{X}$ & $\mathrm{X}$ \\
\hline $\mathrm{A}_{3}$ (forest composition) & -0.2671 & 0.2147 & $\mathbf{- 1 . 5 5 4 3 * *}$ & -0.0105 & $\mathbf{- 1 . 1 6 3 2}$ & -0.2307 & -0.2194 & -0.2651 \\
\hline $\mathrm{HS}_{1} \mathrm{~A}_{1}$ & $\mathrm{X}$ & $\mathrm{X}$ & $\mathrm{X}$ & $\mathrm{X}$ & $\mathrm{X}$ & $\mathrm{X}$ & $\mathrm{X}$ & $\mathrm{X}$ \\
\hline $\mathrm{HS}^{*} \mathrm{~A}_{2}$ & $\mathrm{X}$ & $\mathrm{X}$ & $\mathrm{X}$ & $\mathrm{X}$ & $\mathrm{X}$ & $\mathrm{X}$ & $\mathrm{X}$ & $\mathrm{X}$ \\
\hline $\mathrm{HS}^{*} \mathrm{~A}_{3}$ & $\mathrm{X}$ & $\mathrm{X}$ & $\mathrm{X}$ & $\mathrm{X}$ & $\mathrm{X}$ & $\mathrm{X}$ & $\mathrm{X}$ & $\mathrm{X}$ \\
\hline
\end{tabular}




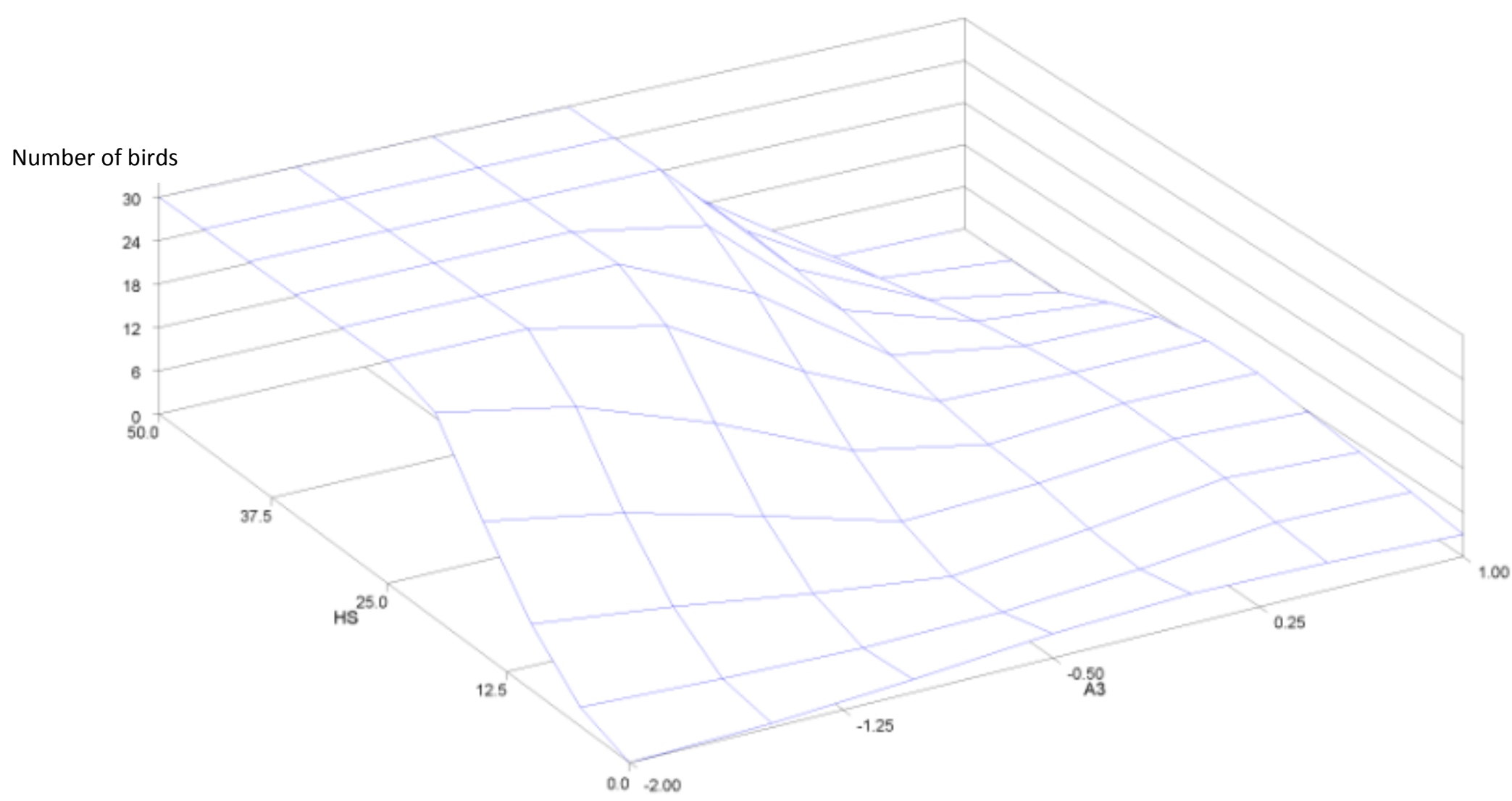

Figure 9. 3-dimensional depiction of the fixed effects included in the model for the abundance (number) of American robins in all 13 forest stands for the fall of year $2(p=0.0039$; FDR $p=0.0313)$. Effects of the interaction between percent honeysuckle cover (HS) and the forest composition representative axis $3\left(\mathrm{~A}_{3}\right)$ are represented by the fluctuations in the plane of the figure. 


\section{Eastern towhees}

The most commonly observed bird species within the sparrow family Emberizidae was the Eastern towhee (Pipilo erythrophthalmus). The negative binomial distribution was used and the model with the lowest AIC value for towhee abundance had no effects. Therefore, there were no differences in towhee abundance due to the effect of percent honeysuckle cover or forest stand composition.

\section{Tufted titmice and Carolina chickadees}

The Tufted titmouse (Baeolophus bicolor) and Carolina chickadee (Poecile carolinensis), members of the family Paridae, were commonly observed species. Both birds are considered mid-canopy species. The Poisson distribution was used and the model with the lowest AIC value for titmice abundance included percent honeysuckle cover as the only fixed effect. Titmouse abundance was negatively impacted by percent honeysuckle in the spring and fall of both years (Table 4); however, the effect was very small and not significant. For chickadees, the Poisson distribution was used and the best model included $\mathrm{A}_{2}$ only (Table 5); there were no significant impacts of $\mathrm{A}_{2}$ on chickadee abundance. 
Table 4. Parameter estimates of fixed effects included in the model on the abundance (number) of tufted titmice in all 13 forest stands within each season for both study years. The Xs represent effects which did not contribute to the model selected based on AIC.

\begin{tabular}{|c|c|c|c|c|c|c|c|c|}
\hline \multicolumn{7}{|c|}{ Abundance of tufted titmice } \\
\hline & \multicolumn{9}{|c|}{ Year 1 Parameter Estimates } & \multicolumn{3}{c|}{ Year 2 Parameter Estimates } \\
\hline & Winter & Spring & Summer & Fall & Winter & Spring & Summer & Fall \\
\hline \% honeysuckle (HS) & -0.0139 & -0.0015 & 0.0048 & -0.0162 & 0.0129 & -0.0062 & -0.0077 & -0.0088 \\
\hline $\mathrm{A}_{1}$ (forest composition) & $\mathrm{X}$ & $\mathrm{X}$ & $\mathrm{X}$ & $\mathrm{X}$ & $\mathrm{X}$ & $\mathrm{X}$ & $\mathrm{X}$ & $\mathrm{X}$ \\
\hline $\mathrm{A}_{2}$ (forest composition) & $\mathrm{X}$ & $\mathrm{X}$ & $\mathrm{X}$ & $\mathrm{X}$ & $\mathrm{X}$ & $\mathrm{X}$ & $\mathrm{X}$ & $\mathrm{X}$ \\
\hline $\mathrm{A}_{3}$ (forest composition) & $\mathrm{X}$ & $\mathrm{X}$ & $\mathrm{X}$ & $\mathrm{X}$ & $\mathrm{X}$ & $\mathrm{X}$ & $\mathrm{X}$ & $\mathrm{X}$ \\
\hline $\mathrm{HS}^{*} \mathrm{~A}_{1}$ & $\mathrm{X}$ & $\mathrm{X}$ & $\mathrm{X}$ & $\mathrm{X}$ & $\mathrm{X}$ & $\mathrm{X}$ & $\mathrm{X}$ & $\mathrm{X}$ \\
\hline $\mathrm{HS}^{*} \mathrm{~A}_{2}$ & $\mathrm{X}$ & $\mathrm{X}$ & $\mathrm{X}$ & $\mathrm{X}$ & $\mathrm{X}$ & $\mathrm{X}$ & $\mathrm{X}$ & $\mathrm{X}$ \\
\hline $\mathrm{HS}^{*} \mathrm{~A}_{3}$ & $\mathrm{X}$ & $\mathrm{X}$ & $\mathrm{X}$ & $\mathrm{X}$ & $\mathrm{X}$ & $\mathrm{X}$ & $\mathrm{X}$ & $\mathrm{X}$ \\
\hline
\end{tabular}


Table 5. Parameter estimates of fixed effects included in the model on the abundance (number) of Carolina chickadees in all 13 forest stands within each season for both study years. The Xs represent effects which did not contribute to the model selected based on AIC.

\begin{tabular}{|c|c|c|c|c|c|c|c|c|}
\hline \multicolumn{10}{|c|}{ Abundance of Carolina chickadees } \\
\hline & \multicolumn{9}{|c|}{ Year 1 Parameter Estimates } & \multicolumn{4}{c|}{ Year 2 Parameter Estimates } \\
\hline & Winter & Spring & Summer & Fall & Winter & Spring & Summer & Fall \\
\hline \% honeysuckle (HS) & $\mathrm{X}$ & $\mathrm{X}$ & $\mathrm{X}$ & $\mathrm{X}$ & $\mathrm{X}$ & $\mathrm{X}$ & $\mathrm{X}$ & $\mathrm{X}$ \\
\hline $\mathrm{A}_{1}$ (forest composition) & $\mathrm{X}$ & $\mathrm{X}$ & $\mathrm{X}$ & $\mathrm{X}$ & $\mathrm{X}$ & $\mathrm{X}$ & $\mathrm{X}$ & $\mathrm{X}$ \\
\hline $\mathrm{A}_{2}$ (forest composition) & -0.1322 & 0.3450 & 0.1653 & 0.0724 & 0.5270 & 0.7233 & 0.0171 & 0.0085 \\
\hline $\mathrm{A}_{3}$ (forest composition) & $\mathrm{X}$ & $\mathrm{X}$ & $\mathrm{X}$ & $\mathrm{X}$ & $\mathrm{X}$ & $\mathrm{X}$ & $\mathrm{X}$ & $\mathrm{X}$ \\
\hline $\mathrm{HS}^{*} \mathrm{~A}_{1}$ & $\mathrm{X}$ & $\mathrm{X}$ & $\mathrm{X}$ & $\mathrm{X}$ & $\mathrm{X}$ & $\mathrm{X}$ & $\mathrm{X}$ & $\mathrm{X}$ \\
\hline $\mathrm{HS}^{*} \mathrm{~A}_{2}$ & $\mathrm{X}$ & $\mathrm{X}$ & $\mathrm{X}$ & $\mathrm{X}$ & $\mathrm{X}$ & $\mathrm{X}$ & $\mathrm{X}$ & $\mathrm{X}$ \\
\hline $\mathrm{HS}^{*} \mathrm{~A}_{3}$ & $\mathrm{X}$ & $\mathrm{X}$ & $\mathrm{X}$ & $\mathrm{X}$ & $\mathrm{X}$ & $\mathrm{X}$ & $\mathrm{X}$ & $\mathrm{X}$ \\
\hline
\end{tabular}




\section{Carolina wrens}

The abundance of the Carolina wren (Thryothorus ludovicianus), a common understory bird, was analyzed using the Poisson distribution and the best model included the fixed effects of percent honeysuckle cover, $\mathrm{A}_{2}, \mathrm{~A}_{3}$, interaction between honeysuckle and $\mathrm{A}_{2}$, and the interaction between honeysuckle and $\mathrm{A}_{3}$. Honeysuckle density had varied seasonal impacts on wren abundance but it had a slightly positive influence on wren abundance in the spring of both years (Table 6). None of the effects on wren abundance were significant. 
Table 6. Parameter estimates of fixed effects included in the model on the abundance (number) of Carolina wrens in all 13 forest stands within each season for both study years. The Xs represent effects which did not contribute to the model selected based on AIC. (Bolded values indicate p-value is significant, but the FDR p-value is not).

\begin{tabular}{|c|c|c|c|c|c|c|c|c|}
\hline \multicolumn{8}{|c|}{ Abundance of Carolina wrens } \\
\hline & \multicolumn{3}{|c|}{ Year 1 Parameter Estimates } & \multicolumn{3}{c|}{ Year 2 Parameter Estimates } \\
\hline & Winter & Spring & Summer & Fall & Winter & Spring & Summer & Fall \\
\hline \% honeysuckle (HS) & -0.1366 & 0.0090 & 0.0516 & $\mathbf{0 . 1 5 9 8}$ & -0.1604 & 0.0442 & -0.0452 & -0.0049 \\
\hline $\mathrm{A}_{1}$ (forest composition) & $\mathrm{X}$ & $\mathrm{X}$ & $\mathrm{X}$ & $\mathrm{X}$ & $\mathrm{X}$ & $\mathrm{X}$ & $\mathrm{X}$ & $\mathrm{X}$ \\
\hline $\mathrm{A}_{2}$ (forest composition) & 1.3776 & -1.4102 & -0.1196 & $\mathbf{- 3 . 2 4 8 9}$ & 2.1002 & -0.2440 & 0.8098 & -1.2669 \\
\hline $\mathrm{A}_{3}$ (forest composition) & 0.2528 & -0.4305 & -0.0754 & -0.6607 & 1.0817 & -0.3030 & 0.4268 & -0.5946 \\
\hline HS*A $_{1}$ & $\mathrm{X}$ & $\mathrm{X}$ & $\mathrm{X}$ & $\mathrm{X}$ & $\mathrm{X}$ & $\mathrm{X}$ & $\mathrm{X}$ & $\mathrm{X}$ \\
\hline $\mathrm{HS}^{*} \mathrm{~A}_{2}$ & -0.3556 & 0.0810 & -0.0298 & $\mathbf{0 . 0 8 1 0}$ & 0.0588 & -0.0382 & 0.0005 & 0.0360 \\
\hline $\mathrm{HS}^{*} \mathrm{~A}_{3}$ & 3.0839 & 0.0791 & 0.0023 & $\mathbf{0 . 1 5 7 7}$ & -0.1464 & 0.0015 & -0.0597 & 0.0581 \\
\hline
\end{tabular}




\section{Downy woodpeckers and Red-bellied woodpeckers}

The most commonly observed woodpecker species were the downy woodpecker (Picoides pubescens Linnaeus) and the Red-bellied woodpecker (Melanerpes carolinus Linnaeus). The Poisson distribution was used for both species, and the best model included no fixed effects, indicating the best explanation for the distribution of the two species did not involve percent honeysuckle cover or the axes representing the forest stand compositional components.

\section{Blue jays}

Blue jays (Cyanocitta cristata) were analyzed using the Poisson distribution and the best model according to AIC included percent honeysuckle cover and $\mathrm{A}_{2}$. Percent honeysuckle cover had a positive influence on jay abundance in the winter and spring of both years, but a negative influence in the summer and fall of both years (Table 7). Honeysuckle density had a significantly negative impact on blue jay abundance in the summer of year $1(p=0.0058$; FDR $p=0.0460)$ but not in the summer of year $2 . \mathrm{A}_{2}$ also had a significantly positive impact in the summer of year 1 on blue jay abundance $(\mathrm{p}=$ 0.0052; FDR p = 0.0460, Figure 10). 
Table 7. Parameter estimates and significance of fixed effects included in the model on the abundance (number) of blue jays in all 13 forest stands within each season for both study years. The Xs represent effects which did not contribute to the model selected based on AIC. (Bolded values indicate p-value is significant, but the FDR p-value is not; * denotes FDR p-value $\leq$ 0.05 ; ** denotes FDR p-value < 0.01; *** denotes FDR p-value < 0.001).

\begin{tabular}{|c|c|c|c|c|c|c|c|c|}
\hline \multicolumn{10}{|c|}{ Abundance of blue jays } \\
\hline & \multicolumn{9}{|c|}{ Year 1 Parameter Estimates } & \multicolumn{3}{c|}{ Year 2 Parameter Estimates } \\
\hline & Winter & Spring & Summer & Fall & Winter & Spring & Summer & Fall \\
\hline \% honeysuckle (HS) & 0.0331 & 0.0653 & $\mathbf{- 0 . 0 9 8 3 *}$ & -0.0697 & 0.0931 & 0.0166 & -0.0014 & -0.0164 \\
\hline $\mathrm{A}_{1}$ (forest composition) & $\mathrm{X}$ & $\mathrm{X}$ & $\mathrm{X}$ & $\mathrm{X}$ & $\mathrm{X}$ & $\mathrm{X}$ & $\mathrm{X}$ & $\mathrm{X}$ \\
\hline $\mathrm{A}_{2}$ (forest composition) & -0.8513 & -1.1948 & $\mathbf{2 . 2 6 1 3}$ & 1.0614 & -2.6291 & -0.6399 & -1.9271 & 0.7628 \\
\hline $\mathrm{A}_{3}$ (forest composition) & $\mathrm{X}$ & $\mathrm{X}$ & $\mathrm{X}$ & $\mathrm{X}$ & $\mathrm{X}$ & $\mathrm{X}$ & $\mathrm{X}$ & $\mathrm{X}$ \\
\hline $\mathrm{HS}^{*} \mathrm{~A}_{1}$ & $\mathrm{X}$ & $\mathrm{X}$ & $\mathrm{X}$ & $\mathrm{X}$ & $\mathrm{X}$ & $\mathrm{X}$ & $\mathrm{X}$ & $\mathrm{X}$ \\
\hline $\mathrm{HS}^{*} \mathrm{~A}_{2}$ & $\mathrm{X}$ & $\mathrm{X}$ & $\mathrm{X}$ & $\mathrm{X}$ & $\mathrm{X}$ & $\mathrm{X}$ & $\mathrm{X}$ & $\mathrm{X}$ \\
\hline $\mathrm{HS}^{*} \mathrm{~A}_{3}$ & $\mathrm{X}$ & $\mathrm{X}$ & $\mathrm{X}$ & $\mathrm{X}$ & $\mathrm{X}$ & $\mathrm{X}$ & $\mathrm{X}$ & $\mathrm{X}$ \\
\hline
\end{tabular}




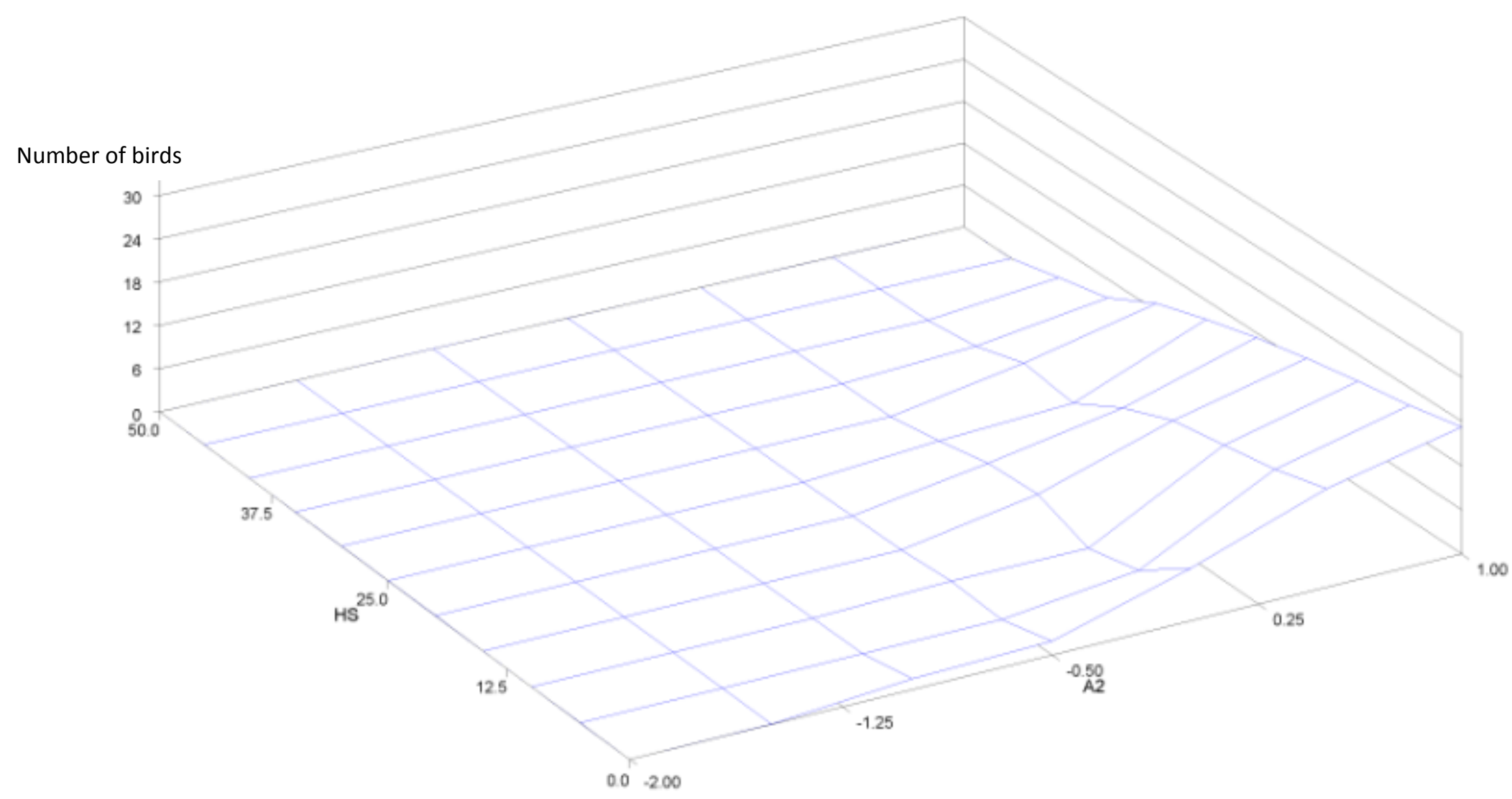

Figure 10. 3-dimensional depiction of the fixed effects included in the model for the abundance (number) of blue jays in all 13 forest stands for the summer of year $1(\mathrm{p}=0.0058$; FDR $\mathrm{p}=0.0460)$. Effects of the interaction between percent honeysuckle cover (HS) and the forest composition representative axis $2\left(\mathrm{~A}_{2}\right)$ are represented by the fluctuations in the plane of the figure. 


\section{White-breasted nuthatches}

The Poisson distribution was used and the model with the lowest AIC value for the abundance of white-breasted nuthatches (Sitta carolinensis) included only percent honeysuckle. Nuthatch abundance was slightly negatively influenced by percent honeysuckle cover in the winter, summer, and fall of both years; however, none of the effects were significant (Table 8). 
Table 8. Parameter estimates of fixed effects included in the model on the abundance (number) of white-breasted nuthatches in all 13 forest stands within each season for both study years. The Xs represent effects which did not contribute to the model selected based on AIC.

\begin{tabular}{|c|c|c|c|c|c|c|c|c|}
\hline \multicolumn{8}{|c|}{ Abundance of white-breasted nuthatches } \\
\hline & \multicolumn{9}{|c|}{ Year 1 Parameter Estimates } & \multicolumn{3}{c|}{ Year 2 Parameter Estimates } \\
\hline & Winter & Spring & Summer & Fall & Winter & Spring & Summer & Fall \\
\hline \% honeysuckle (HS) & -0.0099 & -0.0153 & -0.0350 & -0.0076 & -0.0052 & 0.0161 & -0.0394 & -0.0098 \\
\hline $\mathrm{A}_{1}$ (forest composition) & $\mathrm{X}$ & $\mathrm{X}$ & $\mathrm{X}$ & $\mathrm{X}$ & $\mathrm{X}$ & $\mathrm{X}$ & $\mathrm{X}$ & $\mathrm{X}$ \\
\hline $\mathrm{A}_{2}$ (forest composition) & $\mathrm{X}$ & $\mathrm{X}$ & $\mathrm{X}$ & $\mathrm{X}$ & $\mathrm{X}$ & $\mathrm{X}$ & $\mathrm{X}$ & $\mathrm{X}$ \\
\hline $\mathrm{A}_{3}$ (forest composition) & $\mathrm{X}$ & $\mathrm{X}$ & $\mathrm{X}$ & $\mathrm{X}$ & $\mathrm{X}$ & $\mathrm{X}$ & $\mathrm{X}$ & $\mathrm{X}$ \\
\hline $\mathrm{HS}^{*} \mathrm{~A}_{1}$ & $\mathrm{X}$ & $\mathrm{X}$ & $\mathrm{X}$ & $\mathrm{X}$ & $\mathrm{X}$ & $\mathrm{X}$ & $\mathrm{X}$ & $\mathrm{X}$ \\
\hline $\mathrm{HS}^{*} \mathrm{~A}_{2}$ & $\mathrm{X}$ & $\mathrm{X}$ & $\mathrm{X}$ & $\mathrm{X}$ & $\mathrm{X}$ & $\mathrm{X}$ & $\mathrm{X}$ & $\mathrm{X}$ \\
\hline $\mathrm{HS}^{*} \mathrm{~A}_{3}$ & $\mathrm{X}$ & $\mathrm{X}$ & $\mathrm{X}$ & $\mathrm{X}$ & $\mathrm{X}$ & $\mathrm{X}$ & $\mathrm{X}$ & $\mathrm{X}$ \\
\hline
\end{tabular}




\section{Results for bird families}

Generalized Poisson regression models were used to determine whether the abundance of families of birds sharing similar life history traits were influenced by percent honeysuckle cover, compositional aspects of the forest stands, or interactions between the effects.

\section{Thrushes}

Thrush species (family Turdidae) consisted of birds found throughout the year in the Southeastern region, such as the American robin and Eastern bluebird (Sialia sialis), as well as migratory birds, namely the hermit thrush (Catharus guttatus Pallas), Swainson's thrush (Catharus ustulatus Nuttall), wood thrush (Hylocichla mustelina Gmelin), and veery (Catharus fuscescens Stephens). The negative binomial distribution was used for the analysis of thrush abundance and the fixed effect of percent honeysuckle cover generated the model with the lowest AIC value. The impact of honeysuckle on the abundance of thrush species had varied seasonal effects in the two study years but did have a significantly positive impact in the fall of year $1(\mathrm{p}=0.0034$; FDR $\mathrm{p}=0.01356)$ and year $2(\mathrm{p}=0.0028 ;$ FDR $\mathrm{p}=0.0136)$ (Table 9). Surprisingly, thrush abundance was marginally negatively influenced by honeysuckle density in the spring of both years, but not significantly. Wood thrushes were observed more often in forest stands with relatively high densities of honeysuckle. 
Table 9. Parameter estimates and significance of fixed effects included in the model on the abundance (number) of thrushes in all 13 forest stands within each season for both study years. The Xs represent effects which did not contribute to the model selected based on AIC. (Bolded values indicate p-value is significant, but the FDR p-value is not; * denotes FDR p-value $\leq$ $0.05 ; * *$ denotes FDR p-value $<0.01 ; * * *$ denotes FDR p-value $<0.001)$

\begin{tabular}{|c|c|c|c|c|c|c|c|c|}
\hline \multicolumn{8}{|c|}{ Abundance of thrushes (Family Turdidae) } \\
\hline & \multicolumn{7}{|c|}{ Year 1 Parameter Estimates } & \multicolumn{3}{c|}{ Year 2 Parameter Estimates } \\
\hline & Winter & Spring & Summer & Fall & Winter & Spring & Summer & Fall \\
\hline \% honeysuckle (HS) & 0.0038 & -0.0003 & 0.0018 & $\mathbf{0 . 0 2 4 8 5 *}$ & -0.0062 & -0.0044 & -0.0109 & $\mathbf{0 . 0 4 4 7 7 *}$ \\
\hline $\mathrm{A}_{1}$ (forest composition) & $\mathrm{X}$ & $\mathrm{X}$ & $\mathrm{X}$ & $\mathrm{X}$ & $\mathrm{X}$ & $\mathrm{X}$ & $\mathrm{X}$ & $\mathrm{X}$ \\
\hline $\mathrm{A}_{2}$ (forest composition) & $\mathrm{X}$ & $\mathrm{X}$ & $\mathrm{X}$ & $\mathrm{X}$ & $\mathrm{X}$ & $\mathrm{X}$ & $\mathrm{X}$ & $\mathrm{X}$ \\
\hline $\mathrm{A}_{3}$ (forest composition) & $\mathrm{X}$ & $\mathrm{X}$ & $\mathrm{X}$ & $\mathrm{X}$ & $\mathrm{X}$ & $\mathrm{X}$ & $\mathrm{X}$ & $\mathrm{X}$ \\
\hline $\mathrm{HS}^{*} \mathrm{~A}_{1}$ & $\mathrm{X}$ & $\mathrm{X}$ & $\mathrm{X}$ & $\mathrm{X}$ & $\mathrm{X}$ & $\mathrm{X}$ & $\mathrm{X}$ & $\mathrm{X}$ \\
\hline $\mathrm{HS}_{2} \mathrm{~A}_{2}$ & $\mathrm{X}$ & $\mathrm{X}$ & $\mathrm{X}$ & $\mathrm{X}$ & $\mathrm{X}$ & $\mathrm{X}$ & $\mathrm{X}$ & $\mathrm{X}$ \\
\hline $\mathrm{HS}^{*} \mathrm{~A}_{3}$ & $\mathrm{X}$ & $\mathrm{X}$ & $\mathrm{X}$ & $\mathrm{X}$ & $\mathrm{X}$ & $\mathrm{X}$ & $\mathrm{X}$ & $\mathrm{X}$ \\
\hline
\end{tabular}




\section{Sparrows}

Sparrows (family Emberizidae) were composed of common resident birds, such as the Eastern towhee, the field sparrow (Spizella pusilla Wilson), and song sparrow (Melospiza melodia Wilson), as well as a couple migratory species: the chipping sparrow (Spizella passerina Bechstein) and white-throated sparrow (Zonotrichia albicollis Gmelin). The negative binomial distribution was used and the model with the lowest AIC model included the fixed effects of percent honeysuckle cover, axis $\mathrm{A}_{1}$, and the interaction between percent honeysuckle cover and $\mathrm{A}_{1}$. Due to a very low sparrow count in the winter of year 2, parameter estimates and p-values could not be determined. The impact of honeysuckle on sparrow abundance varied seasonally. In the spring and summer of both years, abundance was positively associated with honeysuckle density Table 10); sparrow abundance was trending towards significant in the spring of year 2 ( $\mathrm{p}$ $=0.0111 ;$ FDR $p=0.08337$, Figure 11) and summer of year $2(p=0.0086 ;$ FDR $p=$ 0.0979, Figure 12). Neither $A_{1}$ nor the interaction between percent honeysuckle cover and $A_{1}$ had significant impacts on sparrow abundance. 
Table 10. Parameter estimates and significance of fixed effects included in the model on the abundance (number) of sparrows in all 13 forest stands within each season for both study years. The Xs represent effects which did not contribute to the model selected based on AIC. (Bolded values indicate p-value is significant, but the FDR p-value is not).

\begin{tabular}{|c|c|c|c|c|c|c|c|c|}
\hline \multicolumn{10}{|c|}{ Abundance of sparrows (Family Emberizidae) } \\
\hline & \multicolumn{3}{|c|}{ Year 1 Parameter Estimates } & \multicolumn{3}{c|}{ Year 2 Parameter Estimates } \\
\hline & Winter & Spring & Summer & Fall & Winter & Spring & Summer & Fall \\
\hline \% honeysuckle (HS) & 0.1081 & 0.0175 & 0.3972 & -0.2560 & -0.3178 & $\mathbf{0 . 3 8 0 6}$ & $\mathbf{0 . 0 2 8 7}$ & 0.0686 \\
\hline $\mathrm{A}_{1}$ (forest composition) & -0.1094 & 0.0053 & 0.3545 & 1.1799 & 0.0000 & -0.1391 & 0.0970 & -0.4122 \\
\hline $\mathrm{A}_{2}$ (forest composition) & $\mathrm{X}$ & $\mathrm{X}$ & $\mathrm{X}$ & $\mathrm{X}$ & $\mathrm{X}$ & $\mathrm{X}$ & $\mathrm{X}$ & $\mathrm{X}$ \\
\hline $\mathrm{A}_{3}$ (forest composition) & $\mathrm{X}$ & $\mathrm{X}$ & $\mathrm{X}$ & $\mathrm{X}$ & $\mathrm{X}$ & $\mathrm{X}$ & $\mathrm{X}$ & $\mathrm{X}$ \\
\hline $\mathrm{HS}^{*} \mathrm{~A}_{1}$ & $\mathbf{0 . 7 4 3 7}$ & -0.0362 & 0.1961 & 1.2645 & 0.0000 & 0.1910 & $\mathbf{0 . 0 4 1 1}$ & 0.0569 \\
\hline $\mathrm{HS}^{*} \mathrm{~A}_{2}$ & $\mathrm{X}$ & $\mathrm{X}$ & $\mathrm{X}$ & $\mathrm{X}$ & $\mathrm{X}$ & $\mathrm{X}$ & $\mathrm{X}$ & $\mathrm{X}$ \\
\hline $\mathrm{HS}^{*} \mathrm{~A}_{3}$ & $\mathrm{X}$ & $\mathrm{X}$ & $\mathrm{X}$ & $\mathrm{X}$ & $\mathrm{X}$ & $\mathrm{X}$ & $\mathrm{X}$ & $\mathrm{X}$ \\
\hline
\end{tabular}




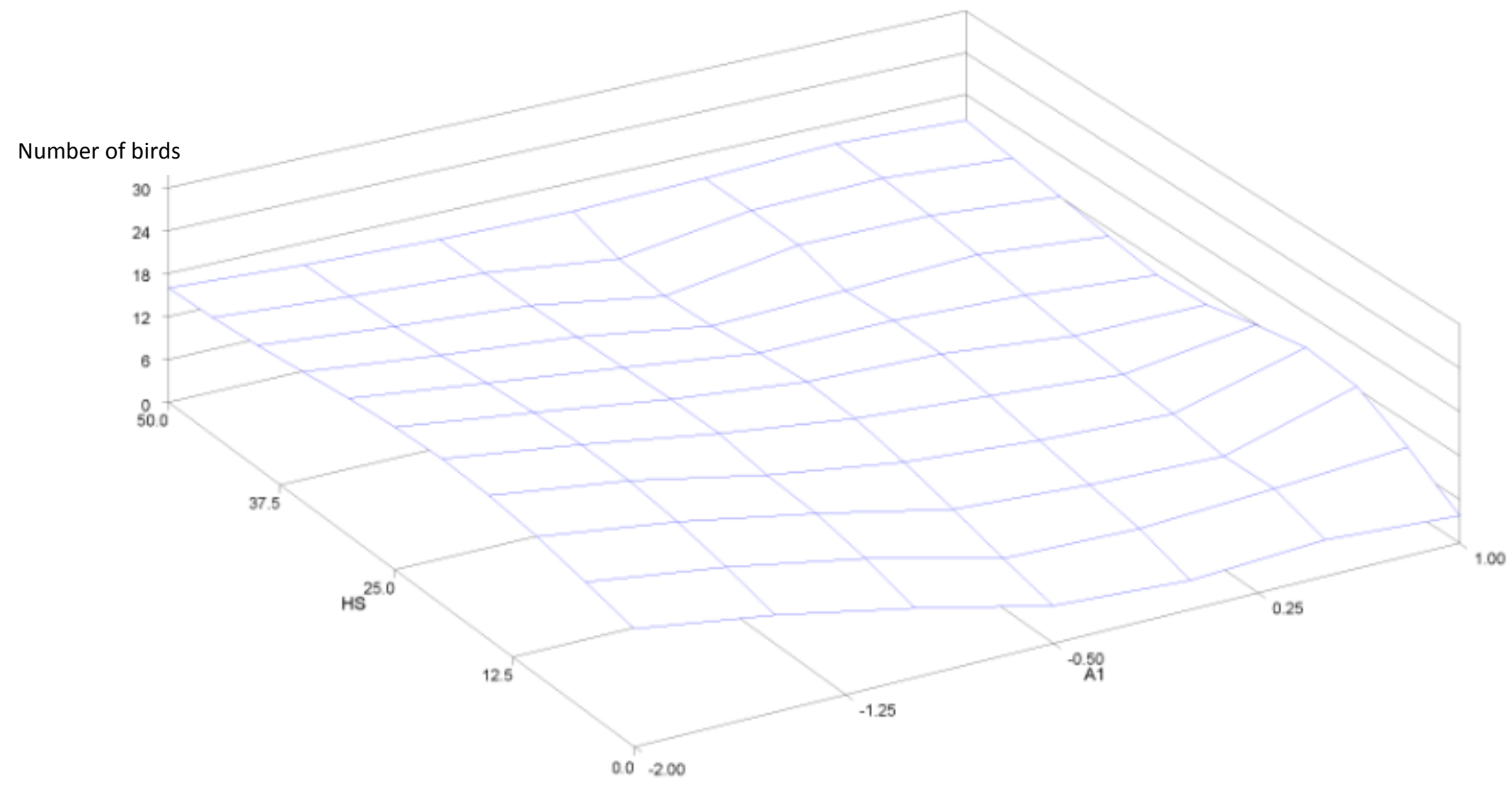

Figure 11. 3-dimensional depiction of the fixed effects included in the model for the abundance (number) of sparrows in all 13 forest stands for the spring of year $2(p=0.0111$; FDR $p=0.0834)$. Effects of the interaction between percent honeysuckle cover (HS) and the forest stand representative axis 1 (A1) are represented by the fluctuations in the plane of the figure. 


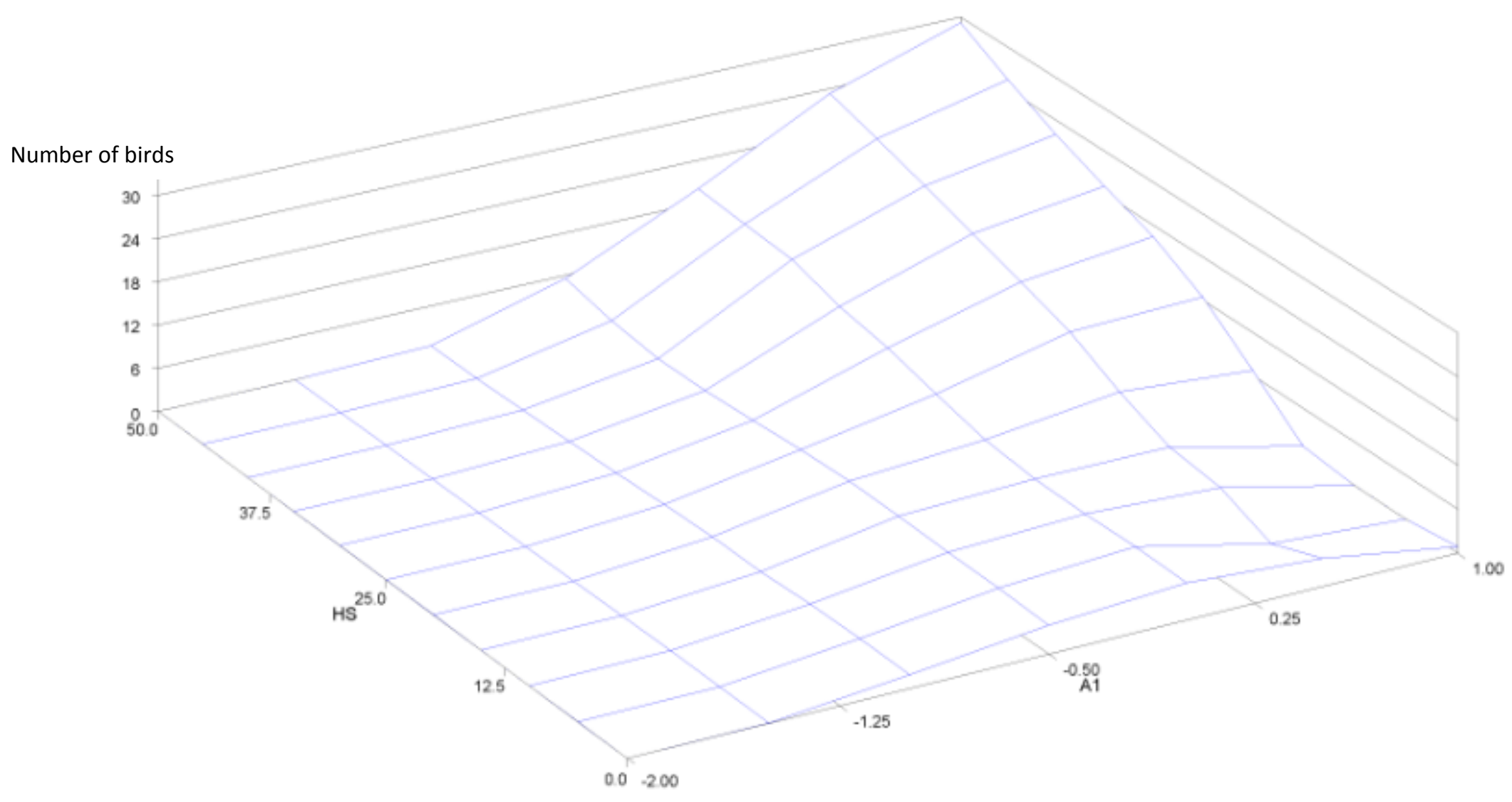

Figure 12. 3-dimensional depiction of the fixed effects included in the model for the abundance (number) of sparrows in all 13 forest stands for the summer of year 2 ( $\mathrm{p}=0.0086$; FDR $\mathrm{p}=0.0979)$. Effects of the interaction between percent honeysuckle cover (HS) and the forest stand representative axis 1 (A1) are represented by the fluctuations in the plane of the figure. 


\section{Parids}

The tufted titmouse and Carolina chickadee were the only two members of the family Paridae observed in my study. The Poisson distribution was used and the fixed effects in the model with the lowest AIC value were percent honeysuckle cover and the forest composition axis $A_{1}$. The impact of honeysuckle density on parid abundance is seasonally varied but was positive in the spring of both years (not significantly, however) and trended towards significance in the winter of year $2(p=0.0142 ;$ FDR $p=0.22664)$ (Table 11). The impact of $A_{1}$ on parid abundance was not significant. 
Table 11. Parameter estimates and significance of fixed effects included in the model on the abundance (number) of Parids in all 13 forest stands within each season for both study years. The Xs represent effects which did not contribute to the model selected based on AIC. (Bolded values indicate p-value is significant, but the FDR p-value is not).

\begin{tabular}{|c|c|c|c|c|c|c|c|c|}
\hline \multicolumn{8}{|c|}{ Abundance of parids (Family Paridae) } \\
\hline & \multicolumn{9}{|c|}{ Year 1 Parameter Estimates } & \multicolumn{3}{c|}{ Year 2 Parameter Estimates } \\
\hline & Winter & Spring & Summer & Fall & Winter & Spring & Summer & Fall \\
\hline \% honeysuckle (HS) & -0.1847 & 0.1495 & 0.1817 & 0.0461 & $\mathbf{0 . 2 8 3 7}$ & 0.0754 & -0.2336 & -0.0724 \\
\hline $\mathrm{A}_{1}$ (forest composition) & -0.0140 & -0.1210 & 0.1421 & 0.1149 & 0.1071 & -0.1259 & -0.0796 & 0.0281 \\
\hline $\mathrm{A}_{2}$ (forest composition) & $\mathrm{X}$ & $\mathrm{X}$ & $\mathrm{X}$ & $\mathrm{X}$ & $\mathrm{X}$ & $\mathrm{X}$ & $\mathrm{X}$ & $\mathrm{X}$ \\
\hline $\mathrm{A}_{3}$ (forest composition) & $\mathrm{X}$ & $\mathrm{X}$ & $\mathrm{X}$ & $\mathrm{X}$ & $\mathrm{X}$ & $\mathrm{X}$ & $\mathrm{X}$ & $\mathrm{X}$ \\
\hline HS*A $_{1}$ & $\mathrm{X}$ & $\mathrm{X}$ & $\mathrm{X}$ & $\mathrm{X}$ & $\mathrm{X}$ & $\mathrm{X}$ & $\mathrm{X}$ & $\mathrm{X}$ \\
\hline $\mathrm{HS}^{*} \mathrm{~A}_{2}$ & $\mathrm{X}$ & $\mathrm{X}$ & $\mathrm{X}$ & $\mathrm{X}$ & $\mathrm{X}$ & $\mathrm{X}$ & $\mathrm{X}$ & $\mathrm{X}$ \\
\hline $\mathrm{HS}^{*} \mathrm{~A}_{3}$ & $\mathrm{X}$ & $\mathrm{X}$ & $\mathrm{X}$ & $\mathrm{X}$ & $\mathrm{X}$ & $\mathrm{X}$ & $\mathrm{X}$ & $\mathrm{X}$ \\
\hline
\end{tabular}




\section{Woodpeckers}

The family of woodpeckers (Picidae) consisted of resident bird species, such as the downy woodpecker, the red-bellied woodpecker, the hairy woodpecker (Picoides villosus Linnaeus), northern flicker (Colaptes auratus Linnaeus), and the pileated woodpecker (Dryocopus pileatus Linnaeus), as well as a winter resident, the yellowbellied sapsucker (Sphyrapicus varius Linnaeus). The Poisson distribution was used for analyses of woodpecker abundance and the best fitting model included honeysuckle percent cover and the forest composition axis $\mathrm{A}_{2}$. Woodpecker abundance varied seasonally with honeysuckle density, but was positively influenced in the winter, spring and summer of both years (insignificantly however), and trended towards significance in the winter of year $2(\mathrm{p}=0.0106 ;$ FDR $\mathrm{p}=0.16945)($ Table 12$) . \mathrm{A}_{2}$ did not have any significant effects on woodpecker abundance. 
Table 12. Parameter estimates and significance of fixed effects included in the model on the abundance (number) of woodpeckers in all 13 forest stands within each season for both study years. The Xs represent effects which did not contribute to the model selected based on AIC. (Bolded values indicate p-value is significant, but the FDR p-value is not).

\begin{tabular}{|c|c|c|c|c|c|c|c|c|}
\hline \multicolumn{10}{|c|}{ Abundance of woodpeckers (Family Picidae) } \\
\hline & \multicolumn{9}{|c|}{ Year 1 Parameter Estimates } & \multicolumn{3}{c|}{ Year 2 Parameter Estimates } \\
\hline & Winter & Spring & Summer & Fall & Winter & Spring & Summer & Fall \\
\hline \% honeysuckle (HS) & 0.0094 & 0.3286 & 0.0605 & -0.1861 & $\mathbf{0 . 7 9 1 0}$ & 0.5981 & 0.1093 & 0.2378 \\
\hline $\mathrm{A}_{1}$ (forest composition) & $\mathrm{X}$ & $\mathrm{X}$ & $\mathrm{X}$ & $\mathrm{X}$ & $\mathrm{X}$ & $\mathrm{X}$ & $\mathrm{X}$ & $\mathrm{X}$ \\
\hline $\mathrm{A}_{2}$ (forest composition) & -0.1797 & -0.6724 & -0.3876 & 0.0091 & $\mathbf{- 0 . 7 1 6 8}$ & -0.3746 & -0.4846 & -0.3372 \\
\hline $\mathrm{A}_{3}$ (forest composition) & $\mathrm{X}$ & $\mathrm{X}$ & $\mathrm{X}$ & $\mathrm{X}$ & $\mathrm{X}$ & $\mathrm{X}$ & $\mathrm{X}$ & $\mathrm{X}$ \\
\hline $\mathrm{HS} * \mathrm{~A}_{1}$ & $\mathrm{X}$ & $\mathrm{X}$ & $\mathrm{X}$ & $\mathrm{X}$ & $\mathrm{X}$ & $\mathrm{X}$ & $\mathrm{X}$ & $\mathrm{X}$ \\
\hline $\mathrm{HS} * \mathrm{~A}_{2}$ & $\mathrm{X}$ & $\mathrm{X}$ & $\mathrm{X}$ & $\mathrm{X}$ & $\mathrm{X}$ & $\mathrm{X}$ & $\mathrm{X}$ & $\mathrm{X}$ \\
\hline $\mathrm{HS}^{*} \mathrm{~A}_{3}$ & $\mathrm{X}$ & $\mathrm{X}$ & $\mathrm{X}$ & $\mathrm{X}$ & $\mathrm{X}$ & $\mathrm{X}$ & $\mathrm{X}$ & $\mathrm{X}$ \\
\hline
\end{tabular}




\section{Warblers}

The family Parulidae consists of migratory insectivorous songbirds, the majority of which prefer the canopy. No species of warbler was observed frequently, due to their seasonality in the study region as well as their small size, which makes them quite inconspicuous. Warblers observed during the study more than once were the blackpoll warbler (Setophaga striata Forster), the black-throated green warbler (Setophaga virens Gmelin), the Kentucky warbler (Geothlypis formosa Wilson), the Nashville warbler (Oreothlypis ruficapilla Wilson), the palm warbler (Setophaga palmarum Gmelin), the pine warbler (Setophaga pinus Wilson), the yellow-rumped warbler (Setophaga coronata Linnaeus), and the yellow warbler (Setophaga petichia Linnaeus). The Poisson distribution was used for analyses of warbler abundance and the model of best fit according to AIC included $\mathrm{A}_{1}$ and $\mathrm{A}_{3}$, neither of which had a significant impact on warbler abundance (Table 13). There were so few warblers observed in the summer of both years, in the fall of year 1 and in the winter of year 2 that statistical results were not able to be obtained. 
Table 13. Parameter estimates and significance of fixed effects included in the model on the abundance (number) of warblers in all 13 forest stands within each season for both study years. The Xs represent effects which did not contribute to the model selected based on AIC. (Bolded values indicate p-value is significant, but the FDR p-value is not).

\begin{tabular}{|c|c|c|c|c|c|c|c|c|}
\hline \multicolumn{10}{|c|}{ Abundance of warblers (Family Parulidae) } \\
\hline & \multicolumn{2}{|c|}{ Year 1 Parameter Estimates } & \multicolumn{3}{c|}{ Year 2 Parameter Estimates } \\
\hline & Winter & Spring & Summer & Fall & Winter & Spring & Summer & Fall \\
\hline \% honeysuckle (HS) & $\mathrm{X}$ & $\mathrm{X}$ & $\mathrm{X}$ & $\mathrm{X}$ & $\mathrm{X}$ & $\mathrm{X}$ & $\mathrm{X}$ & $\mathrm{X}$ \\
\hline $\mathrm{A}_{1}$ (forest composition) & 0.7079 & $\mathbf{1 . 0 3 9 0}$ & - & - & - & -0.0939 & - & 0.0000 \\
\hline $\mathrm{A}_{2}$ (forest composition) & $\mathrm{X}$ & $\mathrm{X}$ & $\mathrm{X}$ & $\mathrm{X}$ & $\mathrm{X}$ & $\mathrm{X}$ & $\mathrm{X}$ & $\mathrm{X}$ \\
\hline $\mathrm{A}_{3}$ (forest composition) & 2.6773 & $\mathbf{0 . 5 9 8 3}$ & - & - & - & 0.5124 & - & 0.0000 \\
\hline $\mathrm{HS}^{*} \mathrm{~A}_{1}$ & $\mathrm{X}$ & $\mathrm{X}$ & $\mathrm{X}$ & $\mathrm{X}$ & $\mathrm{X}$ & $\mathrm{X}$ & $\mathrm{X}$ & $\mathrm{X}$ \\
\hline $\mathrm{HS}^{*} \mathrm{~A}_{2}$ & $\mathrm{X}$ & $\mathrm{X}$ & $\mathrm{X}$ & $\mathrm{X}$ & $\mathrm{X}$ & $\mathrm{X}$ & $\mathrm{X}$ & $\mathrm{X}$ \\
\hline $\mathrm{HS}^{*} \mathrm{~A}_{3}$ & $\mathrm{X}$ & $\mathrm{X}$ & $\mathrm{X}$ & $\mathrm{X}$ & $\mathrm{X}$ & $\mathrm{X}$ & $\mathrm{X}$ & $\mathrm{X}$ \\
\hline
\end{tabular}




\section{Flycatchers}

The family Tyrannidae consists of flycatchers, wood-pewees, and phoebes.

During the study, species within the family Tyrannidae observed were the Eastern woodpewee (Contopus virens), the Eastern phoebe (Sayornis phoebe Latham), and the willow flycatcher (Empidonax traillii Audubon). The Poisson distribution was used and the bestfitting model included no fixed effects. Neither honeysuckle cover nor forest stand composition influenced Tyrannidae abundance, but flycatcher counts were low; this scarcity contributed to the lack of perceptible impact from any of the effects of honeysuckle on Tyrannidae density. There were approximately half as many Eastern wood-pewees in forest stands with high densities of honeysuckle compared to stands with low densities. 


\section{CHAPTER 7: CORRELATIONS BETWEEN HONEYSUCKLE AND OTHER FOREST CHARACTERISTICS}

Honeysuckle density could correlate with tree stand diversity and/or other characteristics of forest stands. I examined the correlation honeysuckle has with the following forest environmental variables: percent canopy cover, mean tree height, and anthropogenic influence (AI). Based on earlier results by previous authors, I predicted honeysuckle density would positively correlate with AI, while honeysuckle density will negatively correlate with percent canopy cover and mean tree height.

\section{Statistical Analysis}

I used Pearson correlation, using PROC CORR of SAS (Goodnight 2015) to test the relationship between percent honeysuckle cover and select characteristics of the forest stands. Analyses examined correlations between percent honeysuckle cover and tree stand diversity (Simpson's Diversity $\mathrm{N}_{2}$ ), percent canopy cover, AI, and mean tree height of forest stands.

\section{Results}

The correlation between percent honeysuckle cover and forest stand diversity was not significant $(\mathrm{r}=-0.0403 ; \mathrm{p}=0.6844)$; graphs of the data show the highest tree stand diversity at intermediate levels of percent honeysuckle cover. The correlation between 
anthropogenic index (AI) and percent honeysuckle cover was not significant $(r=0.0129$; $p=0.8966)$. The correlation between percent canopy cover and percent honeysuckle cover was not significant either $(r=-0.1225 ; \mathrm{p}=0.2154)$. In contrast, there was a strongly significant negative relationship between mean tree height and percent honeysuckle cover $(r=-0.6166 ; p=<0.0001)$. Figure 13 depicts the relationships between four variables of the forest stands and percent honeysuckle cover. 


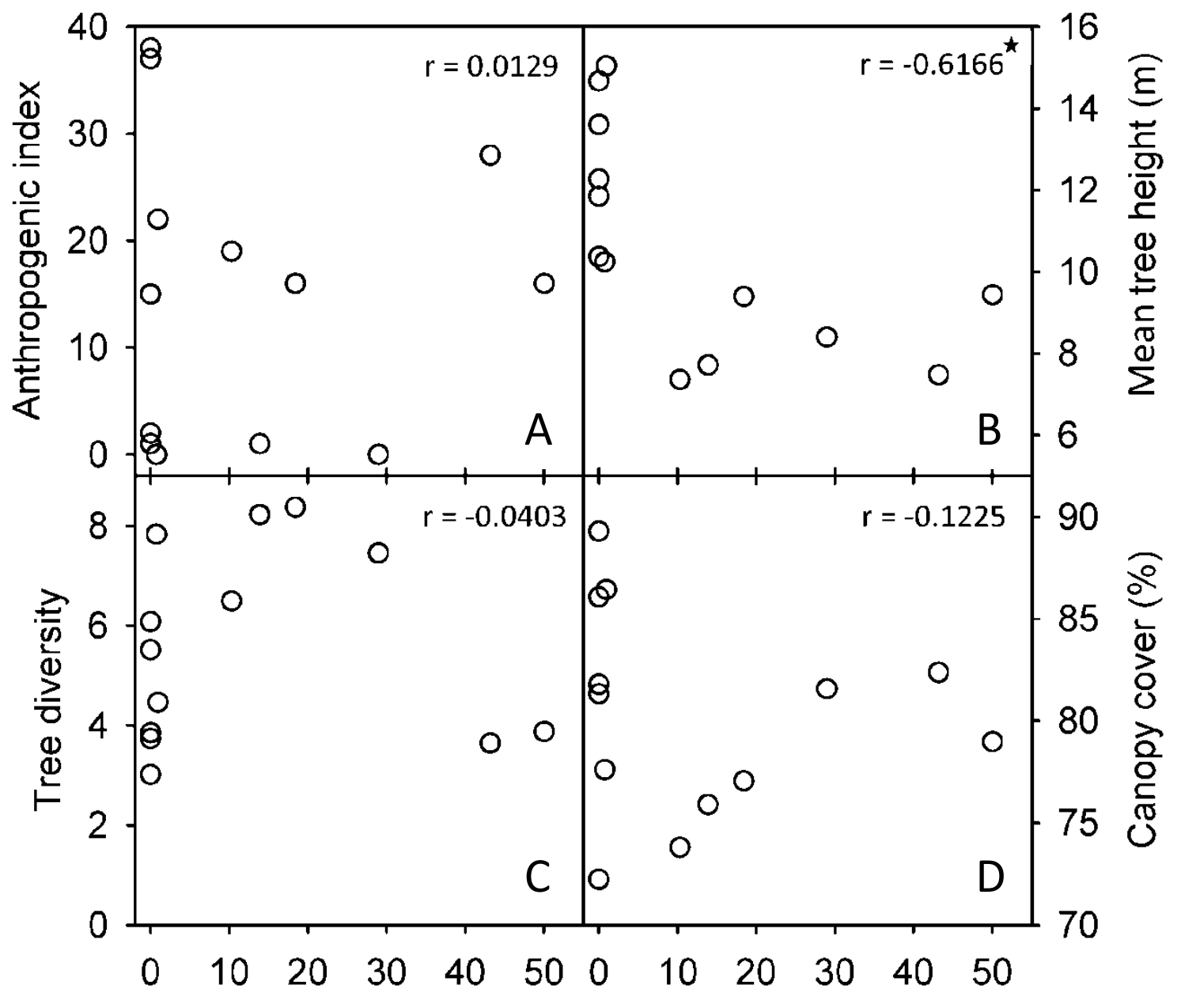

Honeysuckle cover (\%) Honeysuckle cover (\%)

Figure 13. Correlations of honeysuckle density and forest stand characteristics at all 13 forest stands. Starred correlations are significant. 


\section{CHAPTER 8: DISCUSSION}

\section{Effects of honeysuckle on bird diversity}

Birds are a very good indicator of habitat health (Yarnold 2015); bird community composition and diversity of forest habitat provide valuable insights about the functionality of an ecosystem. Invasive plant species have become quite prevalent in the $21^{\text {st }}$ century due to the ease of human travel and the introduction of ornamentals. While invasive species are often a nuisance, only 10 to $30 \%$ invasive species have been known to cause harmful effects (Simberloff 2013). In some cases, impacts of invasive plants are obvious. For example, in some locations the invasive shrub honeysuckle Lonicera maackii formed a monoculture and visibly was the dominant plant species. Other times, effects of invasive species on specific organisms are more subtle, as with the impact of Amur honeysuckle on bird communities.

A few studies have investigated the effects of Amur honeysuckle on birds. One such study by McCuster et al. (2010) demonstrated an increase in understory bird species, particularly northern cardinals, and a decrease in upper canopy bird species, notably eastern wood-pewees, during the breeding season in rural forests of Illinois that have high densities of bush honeysuckle, compared to nearby forests void of the shrub. The study also displayed a higher abundance of frugivores, mainly American robins, in forest 
dominated by honeysuckle compared to forests without honeysuckle once fruit was produced McCuster et al. 2010). Over $60 \%$ of invasive shrubs are bird dispersed and Amur honeysuckle does not seem to be an exception to this phenomenon (Richardson and Rejmáek 2011).Some bird species have been known to consume honeysuckle fruits (e.g., robins, European starlings, hermit thrushes, northern mockingbirds, and cedar waxwings); however, robins are the only bird so far studied in which gut passage does not inhibit seed development (Bartuszevige and Gorchov 2006). American robins and honeysuckle appear to have developed a mutualism that has created a positive feedback loop facilitating the spread of honeysuckle. The fact that honeysuckle berries are a poor energy source, due to their high $\mathrm{C}: \mathrm{N}$ ratio and low lipid content, does not seem to impact their consumption by robins (Ingold and Craycraft 1983).

Earlier studies have shown no preference of frugivores for native fruits compared to exotics or, in some cases, an inclination towards exotic fruits. A study by Drummond (2005) compared fruit choice, removal by birds, and caloric content of invasive versus native plant fruits in fall and winter of central Maine. The invasive plants were Tartarian honeysuckle (Lonicera tatarica) and multiflora roses (Rosa multiflora Thunb.) while the native plants were species of dogwood and viburnum common to the eastern North America (Drummond 2005). Fruit of multiflora rose and the native dogwood ripen in the late summer whereas fruit of the honeysuckle and the native viburnum ripen in the fall. Comparisons of fruit removal revealed that frugivores favored fruits of dogwood and honeysuckle in the late summer and early fall, respectively, but did not differentiate between fruits of multiflora rose and viburnum during choice trials. Even though the fruit of native plants had significantly higher caloric content than the invasive plants, native 
fruits were not consumed more frequently (Drummond 2005). Another study comparing frugivory rates on two shrubs, the native American holly and the invasive bittersweet, found no difference in fruit removal between the two species. No preference for fruit of native or exotic plants was similarly observed in a study that compared frugivory rates on five native plants to those rates observed for an invasive wild blackberry bush and privet (Greenberg et al. 2001; Montaldo 2000). In summary, all of these studies collectively describe how frugivorous birds do not seem to discriminate on the basis of fruit of native versus invasive plant species or on the caloric content of fruit, but birds do discriminate with respect to fruit quantity and conspicuousness; both attributes are qualities possessed by honeysuckle fruit. In other cases, the non-indigenous species are preferred by frugivores, presumably due to larger fruit size and abundances (Sallabanks 1993; Vial and D'Antonio 1998). An invasive species of hawthorn (Crataegus monogyna) produced larger fruit crop size and average fruit size relative to the native hawthorn (Crataegus douglasii suksdorfii) contributing to higher rates of frugivory of non-native hawthorn fruits in a study in Oregon (Sallabanks 1993). Another study in California demonstrated larger plant size and fruit crop size of a non-indigenous succulent plant (Carpobrotus edulis) compared to the native congener (Carpobrotus chilensis) (Vial and D'Antonio 1998). Total fruit removal of the non-native plant was higher compared to that of the native plant and fruit of the non-native plant was preferred by frugivores in a fruit transplant experiment (Vial and D'Antonio 1998).

I executed a regional examination (using thirteen forest stands with varying densities of honeysuckle) that spanned all seasons in order to determine whether any broad changes in avian diversity occurred among the different forest stands. I predicted a 
decrease in bird diversity would occur with an increase in honeysuckle density because certain bird species known to benefit from honeysuckle would increase in dominance (namely cardinals in the spring and summer and robins in the fall; McCuster et al. 2010), thereby decreasing evenness and ultimately decreasing species diversity. I also predicted forest stands with a high percent canopy cover and taller average tree heights would exhibit higher bird diversity, because of the habitat refuge provided by a dense canopy and increase in microhabitat availability created by larger trees. Bird censuses from a variety of North American forests have reported maximal bird density in forests with the highest canopy height (James and Wamer 1982). I found that honeysuckle density within the forest stands did have a significantly negative impact on avian diversity (Figure 2). Though the impact of honeysuckle density on bird diversity overall was not seasonally dependent, it was most pronounced in the spring. These results are similar to those observed in the study by McCuster et al. (2010) in which bird communities in forests with honeysuckle differed from those without during the breeding season (spring and summer). Of the forest stand characteristics measured in my study, only the degree of urbanization (measured by anthropogenic index) had a significantly negative influence on bird diversity, i.e., the more human-impacted stands displayed lower bird diversity (Figure 6). The impact of anthropogenic influence on bird diversity did not vary seasonally, but was the highest in the spring and summer, more than likely due to high bird counts during these seasons. Tree diversity, canopy cover, and tree height did not appear to impact bird diversity among the forest stands; however, these stand characteristics did have a slight positive, nonsignificant impact on bird diversity (Figure 3; Figure 4; Figure 5). The interaction between tree diversity and mean tree height 
significantly impacted bird diversity positively; tree diversity impacted bird diversity differently based on average tree height. This impact was also the highest in the spring and summer.

\section{Mechanisms responsible for changes in avian diversity due to honeysuckle}

The negative impact of honeysuckle density on bird diversity implies that either the number of bird species, or abundance of some bird species, decreases with increasing honeysuckle density. Increased dominance of certain bird species in stands with relatively high densities of honeysuckle could cause a decrease in overall diversity. Specifically, I predicted increased abundance of understory species (such as cardinals, thrushes, and sparrows) in forest stands with high densities of honeysuckle and decreased abundance of species preferring the mid- to upper-canopy (specifically, wood-pewees, flycatchers, parids, warblers, and woodpeckers) most noticeably in the spring and summer. I also expected birds foraging on the large number of honeysuckle berries to be more abundant in areas with high honeysuckle density in the fall when the fruits become available (Ingold and Craycraft 1983). I predicted the American robin, a conspicuous facultative frugivore that shifts its diet from insects to fruit in the fall and winter, would increase in abundance in those forest stands containing honeysuckle in the fall, in order to take advantage of the plentiful fruit supplied by the shrubs.

Analyses of Northern cardinals in this study revealed a positive influence of honeysuckle density on cardinal abundance in all seasons of both years that was significant in the summer of year 2 (Figure 8). Cardinals were the dominant species 
within forest stands with relatively high densities of honeysuckle; their high relative dominance was a cause of the negative relationship between honeysuckle density and bird diversity. The gnarled honeysuckle branches provide an ideal habitat (for perching and protective cover) for cardinals. The study by McCuster et al. (2010) saw similar results in which the abundance of understory species (especially cardinals) was higher in rural forests with $L$ maackii during the breeding season, compared to forests without $L$. maackii. In my study, the model that best described cardinal abundance also included $\mathrm{A}_{1}$ (axis representing forest stand composition) and the interaction between $\mathrm{A}_{1}$ and honeysuckle density (Table 2). Even though Lonicera was not included in the NMDS analysis, forest stands with low densities of honeysuckle and stands with high densities are grouped separately within the ordination indicating characteristics of stands are related to honeysuckle, specifically mean tree height and percent understory cover. The inclusion of $\mathrm{A}_{1}$ in the model for cardinal abundance may be due to the organization of most of the stands with relatively high densities of honeysuckle towards one end of the axis which have lower average tree heights and more understory cover. Additionally, the combined effects of the forest characteristics described by $\mathrm{A}_{1}$ and honeysuckle density explained cardinal abundance, further demonstrating the impact honeysuckle had on forest composition.

Sparrows have similar life histories to cardinals and therefore I predicted sparrows would also benefit from the dense understory cover honeysuckle provides. Sparrows range from inhabiting urbanized areas and suburban neighborhoods (house sparrows and song sparrows) to habitats with particular requirements, such as mesic habitats and open habitats in the case of swamp sparrows and field sparrows, 
respectively. During this study, the most frequently observed sparrows were the Eastern towhees, common in parks and forests of the Southeastern quadrant of the USA, along with several migratory species such as chipping sparrows and white-throated sparrows. Sparrow abundance was positively influenced by honeysuckle density in the spring and summer of both years and trended towards significance in the spring and summer of year 2 (Figure 11; Figure 12). As in cardinals, sparrow abundance was also explained by $\mathrm{A}_{1}$ and the interaction between $A_{1}$ and honeysuckle density (Table 10). These results may be due to the preference of sparrows to forest stands with relatively thick understory cover and low average tree heights, indicative of forests containing dense honeysuckle shrubs.

Another bird family containing species commonly found in the forest understory is the thrush family Turdidae. In both years, overall thrush abundance was negatively influenced by honeysuckle density (the effect was not significant, however) in the spring and summer, while thrush abundance was positively and significantly influenced in the fall season (Table 9). American robins, the most conspicuous thrush (and the secondmost abundant bird observed during the study), are ground-foraging insectivores throughout the warm seasons, but robins switch their diets to fruits in the fall and winter, when insects are scarce. Because robins are known to prefer nesting in the lower branches of trees, it is not surprising that during the study the majority of robins were observed in the mid-canopy layer and that robin abundance was negatively impacted by honeysuckle density in the summer of both years (personal observation; Poole et al. 2005; Table 3). The abundance of robins was also explained by one of the axes representing forest composition, $\mathrm{A}_{3}$, and the effect was highly significant in the summer of year one. The negative impact of $\mathrm{A}_{3}$ on robin abundance, particularly during the breeding season, 
may be due to the preference of robins to nest in trees. Forest stands with abundant nest substrate in trees corresponded to decreased canopy openness and lower densities of honeysuckle. Another thrush species commonly observed in the study, the migratory wood thrush, prefers dense understory habitats (Poole et al. 2005). In this study, wood thrushes were observed more frequently in forest stands with relatively high densities of honeysuckle. McCuster et al. (2010) found that the presence of honeysuckle had a positive influence on wood thrush density in the spring and summer. However, considering all thrush species in this study collectively, there was no evidence for the prediction that thrush abundance would be higher in the thick understory of shrub honeysuckle in the spring and summer.

Nonetheless, thrush abundance was positively impacted by honeysuckle density significantly in the fall of both years (Table 9). The thrush species responsible for this increase was the American robin; robin abundance non-significantly increased with honeysuckle density in the fall of year 1 and significantly increased in the fall of year 2 (Figure 9). With respect to other thrushes, wood thrushes were not found in the study area in the fall and other thrush species were relatively uncommon. The positive relationship between robin abundance and honeysuckle density in the fall is thought to be a consequence of plentiful honeysuckle berries, based on previous studies demonstrating an increase in robin abundance in response to increased fruit abundance (Gleditsch and Carlo 2011).

The results of my study support the prediction that cardinal and sparrow abundance are positively influenced by honeysuckle density, predominantly in the spring and summer, while thrush density was positively influenced by honeysuckle, but only in 
the fall. There were no significant negative impacts to any bird families due to honeysuckle density. However, there were negative impacts to the abundance of some common bird species associated with honeysuckle density that cumulatively contributed to the overall decrease in bird diversity. Bird families which may be less likely to be found in areas with high densities of honeysuckle hypothetically because of their preference for the mid- to upper-canopy are families of the parids, woodpeckers, warblers, wood-pewees and flycatchers.

The impact of honeysuckle on species of parids (Carolina chickadees and tufted titmice) fluctuated across seasons and years, but a positive (though non-significant) association was observed the spring of both years (Table 11). This positive impact of honeysuckle density on parid abundance was a result of slightly more chickadees in stands with honeysuckle; titmice abundance was negatively impacted by honeysuckle in most seasons, specifically in the spring and fall of both years (Table 4). However, chickadees appear to be uninfluenced by the density of honeysuckle within a habitat because honeysuckle density was not a significant factor in the model examining chickadee density (Table 5). $\mathrm{A}_{2}$ did explain chickadee abundance indicating that compositional aspects of the forest were a greater determinant of chickadee distribution than honeysuckle density. The inclusion of $\mathrm{A}_{2}$ in the model describing chickadee abundance may be due to the influence of tree height on chickadees, which are often found in the mid-canopy. McCuster et al. (2010) stated that during the breeding season, parids were half as common in forested areas of central Illinois with honeysuckle compared to areas without; however, the combining of species into Paridae within the study may have prevented distinction between potential differences in species abundance 
within the two treatments. While chickadees and titmice are very similar behaviorally, chickadees have a more omnivorous diet in comparison to the more insectivorous titmice (Poole et al. 2005). This slight difference in diet preference could explain the lack of a significant relationship between honeysuckle and chickadee abundance while titmice seem to somewhat avoid stands with relatively high densities of honeysuckle. The titmice may be spending more time in the mature forests, gleaning insects from trees. In addition to honeysuckle density, $\mathrm{A}_{1}$ was included in the model that best described parid abundance (Table 11). This result may be due to the grouping of forest stands with taller tree heights towards the center of axis 1 on the NMDS and the partiality of parids for the mid-canopy.

Contrary to what was expected, woodpecker (family Picidae) abundance was positively influenced by increasing honeysuckle density in the winter, spring, and summer of both years but never significantly (Table 12). The abundances of the most commonly observed woodpeckers (downy woodpeckers and red-bellied woodpeckers) were not explained by percent honeysuckle cover, according to the regression models. The positive trend of woodpecker density with honeysuckle cover could be a consequence of characteristics of some of the forest stands with high densities of honeysuckle [e.g., Joe Creason Park, E.T. Tom Sawyer Park and Blackacre Preserve], all of which contained streams. Red-bellied woodpeckers, the most abundant woodpecker observed during the study, prefer swampy woodlands and were observed very frequently throughout the study in these mesic stands with dense honeysuckle (Poole et al. 2005). My results contrasted with the findings of McCuster et al. (2010) which demonstrated honeysuckle having a negative influence on the abundance of red-bellied woodpeckers in rural forests of Illinois during the breeding season. Gleditsch and Carlo (2011) also found 
the density of downy and red-bellied woodpeckers negatively correlated with honeysuckle fruit counts in forested areas of Pennsylvania in the fall. In my study, woodpecker abundance was negatively influenced by honeysuckle density in the fall of year 1 , but not in the fall of year 2; these ambiguous results do not strongly suggest that honeysuckle density exerts any significant impact on woodpecker abundance in the fall. $\mathrm{A}_{2}$ was also included in the model for woodpecker abundance. Given that woodpeckers forage and nest in the upper canopy, the inclusion of $\mathrm{A}_{2}$ in the model of woodpecker abundance is logical and indicates woodpecker abundance was influenced by the average tree height of the stands.

The abundance of migratory warblers and members of the family Tyrannidae, wood-pewees and flycatchers, did not seem to be significantly influenced by honeysuckle density. However, the number of warblers and tyrant flycatchers observed throughout the study was too low to indicate any patterns based on honeysuckle density. Warbler abundance was explained by $\mathrm{A}_{1}$ and $\mathrm{A}_{3}$, however, bird counts were too low in some seasons to generate statistical results (Table 13). The inclusion of axes representing compositional aspects of the forest stands in the model for warbler abundance may be due to the influence of mean tree height and canopy openness on warbler distribution (i.e., the majority of warbler species prefer the upper canopy of more closed habitats).

Previous studies have demonstrated that Eastern wood-pewees are half as common in forests with honeysuckle than in forests without honeysuckle (McCuster et al. 2010). Similar results were observed in my study, in which the majority of Tyrannidae observed were Eastern wood-pewees and roughly half as many wood-pewees were observed in stands where honeysuckle was a dominant plant than in stands with low 
honeysuckle dominance. However, the difference in bird abundance was not great enough for honeysuckle cover to explain the abundance of species of Tyrannidae within the model.

Other bird species that were frequently observed during the study were Carolina wrens, white-breasted nuthatches, and blue jays. Wren densities were slightly positively influenced by honeysuckle percent cover in the spring of both years, but not significantly. These results compliment the findings in the McCuster et al. (2010) study in which wren abundance was positively influenced by the presence of honeysuckle during the breeding season. $\mathrm{A}_{2}, \mathrm{~A}_{3}$, and the interactions between these axes and honeysuckle density were also included in the model for wren abundance. $A_{2}$ and $A_{3}$ explain differences in the mean tree heights, percent understory cover, and percent open sky of forest stands. The presence of these axes and honeysuckle in the model that best describes wren abundance may be due to wren preference of habitats with thick shrubs that provide protective cover from predators (Poole et al. 2005). White-breasted nuthatches displayed a consistent negative relationship with honeysuckle cover in the winter, summer and fall of both years, but not significantly. Nuthatches are often seen climbing tree trunks foraging for insects or caching nuts; they prefer habitats with oak trees and based on a study by Wilson et al. (2013) and vegetation surveys performed during my study, forest stands with dense honeysuckle tend to have fewer oak trees. Blue jays were positively associated with honeysuckle density in the spring of both years, but insignificantly. However, blue jay abundance was negatively influenced by honeysuckle density in the summer of both years and significantly in the summer of year 1. These results contrast the outcome of the McCuster et al. (2010) study in which blue jay density was positively 
influenced by the presence of honeysuckle. Blue jays prefer farmland and suburban habitats and are not often found in the understory of mature forests (Poole et al. 2005). Thus, their observed decrease in abundance with increasing honeysuckle density in the summer is expected. $\mathrm{A}_{2}$ also helped to explain blue jay abundance, especially in the summer of year one in which it was significant. $A_{2}$ is explained by the variation in mean tree height and percent understory cover of stands. The inclusion of $\mathrm{A}_{2}$ in the model may be due to the preference of jays for stands with tall, upper canopy trees and not of stands with high understory cover, particularly in the summer. The positive association of blue jays with honeysuckle cover in the spring could be a result of their habit of robbing nests (Poole et al. 2005). Honeysuckle is typically the first vegetation to bud in the early spring. Some species, such as cardinals and robins, have been shown to nest in honeysuckle (Rodewald et al. 2010). The positive influence of honeysuckle on blue jay abundance in the spring may contribute to the documented lower survival rates of nests in honeysuckle early in the breeding season (Rodewald et al. 2010; Schmidt and Whelan 1999).

Shifts in the abundance of some bird families and particular species across varying densities of honeysuckle provide an explanation for the inverse relationship between bird diversity and honeysuckle density which is most pronounced in the spring. The cumulative negative impacts of honeysuckle density on the abundance some birds combined with the increase in dominance of birds preferring honeysuckle created an overall decrease in bird diversity.

Dense areas of honeysuckle do provide plentiful shrubbery and fruit for generalist species, such as cardinals and robins, which are well-adapted to a variety of habitats 
(Rodewald 2012). However, even birds preferring areas with dense honeysuckle are negatively impacted by the shrub through the ephemeral trap its early leaf phenology creates which in turn lowers nest fecundity of some birds, notably cardinals and robins (Rodewald et al. 2010; Schmidt and Whelan 1999). Plumage coloration of male cardinals may also be impacted by honeysuckle associated with increased urbanization in that the relationship between body condition and coloration is weakened in habitats with plentiful carotenoid-rich foods supplied by honeysuckle (Jones et al. 2010). Therefore, the signal of male quality of cardinals is lost in urbanized areas with high abundances of exotic plants (notably honeysuckle) in addition to reduced plumage brightness with the quantity of urbanization surrounding forest matrices in central Ohio (Jones et al. 2010; Rodewald 2012).

\section{Effects of other forest variables on bird diversity}

Honeysuckle density appears to have a minimal impact on some bird families, notably woodpeckers and warblers. Characteristics of the forest stands represented by the axes from the NMDS ordination seem to better explain the abundance of these species within the model. The only characteristic of the forest stands that had a significant impact on bird diversity other than honeysuckle density was the anthropogenic index (AI) (Figure 6). Anthropogenic influence had an overall negative impact on bird diversity that was highest during the breeding season when bird counts were highest. However, there was actually a positive relationship between anthropogenic influence and bird diversity in the winter. This phenomenon may be due to birds visiting bird feeders in urban areas 
during the winter. Other studies have found similar results in which bird abundance and density was higher in natural urban and residential urban areas than in forests, farms, and mixed rural environments of southern Ontario in the winter (Smith 2003). Atchison and Rodewald (2006) found that bird species richness and total abundance were positively associated with urban development when measured along a rural-urban gradient in riparian forest parks in the winter of central Ohio.

In previous studies, highest bird diversity was observed in moderately urbanized areas along an urban gradient; a strong urban gradient effect was not obvious in my study (Blair 1996; Marzluff 2005). The difference in study results could stem from the lack of highly urbanized areas in my study; my primary goal was to compare forest stands with similar compositions that differed in honeysuckle density. Bird diversity was not greatest in stands with moderate AI values, instead, a steady decline in bird diversity with increasing AI values was observed. Similar results have been found in other studies of urbanization effects on bird communities. An assessment of resident birds along habitat gradients in British Columbia examined potential effects of local (within 50 meters) and landscape-level (within 1000 meters) urban habitat attributes. Results of that particular study demonstrated decreased bird species richness corresponding to urban habitat features when assessed at both the local and landscape scale (Melles et al. 2003). This study in which bird diversity decreased significantly with increasing urbanization at the landscape-level (1000 meters) is similar to the results of my study. A study in southwestern Mexico City along an urban gradient yielded decreased species richness of resident birds with increased urbanization intensity enumerated by urban-land use (Ortega-Álvarez and MacGregor-Fors 2009). Rather than examining effects on birds 
within urban areas, Rottenborn (1998) focused on effects of urbanization to bird communities in neighboring riparian habitats in California. Results of the study indicated that bird species richness had a direct relationship with distance to the nearest building and width of the riparian habitat. The riparian habitats closest to buildings displayed the lowest species richness (Rottenborn 1998).

The other compositional aspects of the forest stands (canopy cover, tree height, and tree diversity) had a predicted positive relationship with bird diversity; however, none of these impacts were significant. Bird diversity had a positive relationship with canopy cover in all seasons except fall, in which there was a slight inverse relationship (Figure 3). The seasonal differences may be due to the possibility that forest stands with high percent canopy cover may provide increased protective cover from aerial predators for song birds and increased perching sites. In the fall, when leaves are abscising, canopy cover no longer provides a potential protective effect from aerial predators.

Mean tree height also had a positive relationship with bird diversity, and did so in all seasons (Figure 4). Forest stands with tall, old growth trees may provide more microhabitats and increased niche availability, allowing for more birds (James and Wamer 1982). The positive relationship of bird diversity with average tree height was most pronounced in the spring, more than likely due to a higher abundance of nesting birds. Tree diversity of the forest stands positively influenced bird diversity as well in all seasons except for in the winter, in which there was a negative relationship (Figure 5). Tree diversity boosts bird diversity by providing a variety of tree species attractive to many different bird species. The negative relationship between bird diversity and tree diversity in the winter could be a result of the lack of tree foliage, causing tree diversity 
to be less of a determining factor for birds within this season. The interaction between tree diversity and mean tree height had a highly significant positive impact on bird diversity implying that the combination of tree diversity and tree height is a major factor determining bird diversity, i.e., the most diverse forest stands with an abundance of tall, old growth trees contain the most diverse bird communities.

\section{Correlations between honeysuckle and characteristics of forest stands}

Characteristics of the forest stands were compared to honeysuckle density in order to determine whether there were any correlations between effects that may further explain bird diversity. Amur honeysuckle prefers habitats with adequate light availability, as honeysuckle is slightly shade intolerant, as well as habitats that are at an early to midsuccessional seral stage, urbanized, moderately disturbed, and lack a dense shrub layer (Hutchinson and Vankat 1997). The forest stands utilized in the study varied in density of honeysuckle, extent of urbanization, and in the composition, type, and proportion of other vegetation. In forest stands heavily occupied by honeysuckle, it is not known whether honeysuckle influenced characteristics of the forest stands or if compositional aspects of the stands allowed for invasion of the shrub.

It was predicted that tree diversity of the forest stands (signified by the Simpson's Diversity $\left(\mathrm{N}_{2}\right)$ of each stand) and honeysuckle density would negatively correlate with tree diversity, due either to the potential of honeysuckle to suppress the growth of native plants or to invade less diverse stands more easily. There was a slight negative correlation between tree stand diversity and honeysuckle density, but it was not significant (Figure 
13). However, there was a positive curvilinear relationship between tree diversity and honeysuckle density in which forests with intermediate densities of honeysuckle exhibited the highest tree diversity. Forest stands with the lowest tree diversity are those with either very low or very high densities of honeysuckle.

Forest stands with little to no honeysuckle $(<1 \%$ honeysuckle) were either located away from the inner-city of the Louisville Metropolitan Area or were closelymonitored parks within the city in which honeysuckle has been removed recently by managers. These stands are mostly composed of tree species affiliated with mature forests, such as maples, oaks, ashes, and walnuts. Forest stands consisting of late successional tree species may be more resistant to honeysuckle invasions, by limiting light accessibility to the understory (Hutchinson and Vankat 1997). Similarly, these oldgrowth forests may have lower tree diversity $\left(\mathrm{N}_{2}\right.$ diversity values of 3 to 8$)$ because large dominant tree species decrease light penetration to the forest floor. Stands with low densities of honeysuckle had the highest percent canopy cover and the majority had relatively high percentages of bare ground (>65\% bare ground). Lapping Park, Mt. St. Francis Seminary, Horner Preserve (the area of the preserve with low densities of honeysuckle), Charlestown State Park (area of the park with low densities of honeysuckle) include forest stands with mature vegetation and low densities of honeysuckle. Jefferson Memorial Forest, Cherokee Park and Iroquois Park also have low densities of honeysuckle but removal efforts have been implemented within these parks to stifle honeysuckle invasion.

Forest stands with an intermediate amount of honeysuckle (10 to 30\% honeysuckle) have the most diverse flora ( $\mathrm{N}_{2}$ diversity values of 6 to 9). These stands 
include McNeely Lake Park, Horner Preserve (area of the preserve with high densities of honeysuckle, Blackacre Nature Preserve, and Charlestown State Park (area of the park with high densities of honeysuckle) and consist primarily of a mixture of mid successional tree species, such as junipers, and late successional species, such as maples, oaks, and hickories. Parks with moderate amounts of honeysuckle have lower mean tree heights and denser understory cover compared to those with almost no honeysuckle; the smaller tree heights and thicker understory of these stands is more than likely an impact of honeysuckle.

On the other hand, forest stands with high densities of honeysuckle (> 40\%) have low tree diversity ( $\mathrm{N}_{2}$ diversity values of 3 to 4$)$. This may be due to honeysuckle taking advantage of a less diverse, more open habitat. Alternately, honeysuckle may suppress the growth of tree species and secure dominance. Joe Creason Park and E.T. Tom Sawyer Park have the highest percent honeysuckle cover and the lowest tree diversity of stands with honeysuckle.

These results support the intermediate disturbance hypothesis in which habitats that are moderately disturbed will sustain the highest species diversity in comparison to areas disturbed too frequently or infrequently (Townsend and Scarsbrook 1997). Forest stands with very low honeysuckle density are infrequently disturbed, late successional forests whereas stands with high honeysuckle density are highly disturbed, urbanized parks. Areas with intermediate densities of honeysuckle permit maximal tree diversity. These forest stands are neither overrun by dominating old-growth tree species or by honeysuckle and therefore allow for more tree species. They are a mixture of frequented, 
inner-city parks and more isolated, rural forested areas located on the outskirts of the metropolitan area.

There was a significant negative correlation between honeysuckle density and mean tree height of the forest stand (Figure 13). Forest stands with very low densities of honeysuckle have the tallest mean tree heights (10 to 15 meters) whereas stands with high densities of honeysuckle relatively have the lowest ( 7 to 10 meters). This result is more than likely due to the increase in the shrub layer created by higher densities of honeysuckle (average height of 2 meters) and fewer tall, old growth trees in areas in stands with high percent honeysuckle cover. Stands with low densities of honeysuckle also have the lowest understory coverage ( 3.5 to $15 \%$ understory coverage). Additionally, old growth forests with larger basal area have been shown to be more resistant to honeysuckle invasion (Hutchinson and Vankat 1997).

Canopy cover of forest stands was predicted to negatively correlate with honeysuckle density because honeysuckle may be less capable of invading old-growth forests with closed canopies causing decreased light availability (Hutchinson and Vankat 1997). Percent canopy cover did correlate with honeysuckle density negatively but not significantly (Figure 13). Forest stands with low densities of canopy cover have the densest canopy cover ( 72 to $90 \%$ canopy cover). Percent canopy cover is the highest in forests with low densities of honeysuckle more than likely due to the large, mature trees of these forest stands. Stands with relatively high densities of honeysuckle have less canopy cover ( 73 to $83 \%$ canopy cover). An inverse relationship between canopy cover and shade intolerance index and honeysuckle cover was found in a study of forest communities in southwestern Ohio (Hutchinson and Vankat 1997). 
Honeysuckle density and anthropogenic index did correlate positively; however, the relationship was not significant and the correlation was very weak $(r=0.0129)$ (Figure 13). A study by Hutchinson and Vankat (1997) demonstrated similar results of an inverse relationship between $L$. maackii cover and distance to an urban hub in Ohio. Forests with very low percent honeysuckle cover are the least impacted by human activity as indicated by their low anthropogenic indices and were located farther from the urban center of Greater Louisville. The only exception are two of the parks in which honeysuckle removal efforts have been implemented recently by management (Cherokee Park and Iroquois Park) which have the highest anthropogenic indices of all the sites due to their more central locations within the city. Forest stands with the highest densities of honeysuckle (Joe Creason Park and E.T. Tom Sawyer Park) have moderately high anthropogenic indices; the two parks are located in highly urbanized areas within the city and both are adjacent to busy roads.

\section{Summary}

The outcomes of the study showed that the two major determinants of avian diversity in forest stands in the Louisville area were honeysuckle density and magnitude of anthropogenic influence. It has been well-established that urbanization and invasive species are major threats to biodiversity as habitats are increasingly fragmented and invasive species further disrupt habitat stability (Didham et al. 2005; Liu et al. 2016). Continued efforts to maintain wildlife habitats must be executed to prevent further declines in flora and fauna diversity and preserve native species. 
My study demonstrates how a ubiquitous invasive shrub can reduce bird diversity via the dominance of some species preferring habitats of dense honeysuckle [cardinals, sparrows, and robins] and slight decrease in abundance of some canopy species [titmice, nuthatches, blue jays, and Eastern wood-pewees]. However, a study spanning several years may be necessary to see dramatic impacts of Amur honeysuckle on bird diversity.

Awareness of the potential negative consequences honeysuckle can have to both native flora and fauna will allow land managers to appropriately weigh the costs and benefits of invasion prevention or removal. For example, land managers should be aware of the potential honeysuckle has to decrease bird diversity especially if left unmanaged to establish itself in high densities. Birds have been utilized as an indicator of environmental health for decades, and this study is another example of how observing bird presence/absence and abundance can provide insight into habitat vitality (Yarnold 2015). 


\section{REFERENCES}

Amburgey K (2015) Kentucky Unbridled Spirit. www.kentuckytourism.com/. Accessed 262015

Arthur MA, Bray SR, Kuchle CR, McEwan RW (2012) The influence of the invasive shrub, Lonicera maackii, on leaf decomposition and microbial community dynamics. Plant Ecol 213:1571-1582

Atchison KA, Rodewald AD (2006) The value of urban forests to wintering birds. Nat Area J 26:280-288

Banker MD, Jablonski L (2002) Deciduous woodland dynamics following removal of invasive honeysuckle. Ecological Restoration 20:3

Barriball K, McNutt EJ, Gorchov DL et al (2015) Inferring invasion patterns of Lonicera maackii (Rupr.) Herder (Caprifoliaceae) from the genetic structure of 41 naturalized populations in a recently invaded area. Biol Invasions 17:2387-2402

Bartuszevige AM, Gorchov DL (2006) Avian seed dispersal of an invasive shrub. Biol Invasions 8:1013-1022

Bartuszevige AM, Gorchov DL, Raab L (2006) The relative importance of landscape and community features in the invasion of an exotic shrub in a fragmented landscape. Ecography 29:213-222

Baxter RB (2015) Mount Saint Francis Center for Spirituality. http://mountsaintfrancis.org. Accessed 25 September 2015

Blair BC, Stowasser A (2009) Impact of Lonicera maackii on decomposition rates of native leaf littler in a Southwestern Ohio woodland. Ohio J Sci 109:43-47

Blair RB (1996) Land use and avian species diversity along an urban gradient. Ecol Appl 6:506-519 
Boyce RL, Durtsche RD, Fugal SL (2012) Impact of the invasive shrub Lonicera maackii on stand transpiration and ecosystem hydrology in a wetland forest. Biol Invasions 14:671-680

Bradley BA, Wilcove DS, Oppenheimer M (2010) Climate change increases risk of plant invasion in the Eastern United States. Biol Invasions 12:1855-1872

Buddle CM, Higgins S, Rypstra AL (2004) Ground-dwelling spider assemblages inhabiting riparian forests and hedgerows in an agricultural landscape. Am Midl Nat 151:15-26

Canty J (2014) Weatherbase. Canty Media. www.weatherbase.com. Accessed 15 Jan 2014

Carreiro MM, Zipperer WC (2011) Co-adapting societal and ecological interactions following large disturbances in urban park woodlands. Austral Ecol 36:904-915

Castellano SM, Gorchov DL (2013) White-tailed deer (Odocoileus virginianus) disperse seeds of the invasive shrub, Amur honeysuckle (Lonicera maackii). Natural Areas Association 33:78-80

Cipollini D, Stevenson R, Cipollini K (2008) Contrasting effects of allelochemicals from two invasive plants on the performance of a nonmycorrhizal plant. Int J Plant Sci 169:371-375

Clark CF (2015) Indiana Department of Natural Resources. http://www.in.gov/dnr/. Accessed 11 August 2015

Collier MH, Vankat JL (2002) Diminished plant richness and abundance below Lonicera maackii, an invasive shrub. Am Midl Nat 147:60-71

Conklin K (2015) Clarksville Parks \& Recreation. www.clarksvilleparks.com. Accessed 8 September 2015

Connell JH (1978) Diversity in tropical rain forests and coral reefs. Science 199:13021310

Deering RH, Vankat JL (1999) Forest Colonization and developmental growth of the invasive shrub Lonicera maackii. Am Midl Nat 141:43-50

DeHart L (2015) Frederick Law Olmsted parks. http://www.olmstedparks.org/. Accessed 10 August 2015

Didham RK, Tylianakis JM, Hutchison MA, Ewers RM, Gemmell NJ (2005) Are invasive species the drivers of ecological change? Trends Ecol Evol 20:129-133 
Dorning M, Cipollini D (2006) Leaf and root extracts of the invasive shrub, Lonicera maackii, inhibit seed germination of three herbs with no autotoxic effects. Plant Ecol 184:287-296

Drummond BA (2005) The selection of native and invasive plants by frugivorous birds in Maine. Northeast Nat 12:33-44

Dutra HP, Barnett, K, Reinhardt JR, Marquis RJ, Orrock JL (2011) Invasive plant species alters consumer behavior by providing refuge from predation. Oecologia 166:649657

Gaston KJ (2000) Global patterns in biodiversity. Nature 405:220-227

Gentry AH 1992 (1992) Tropical forest biodiversity: distributional patterns and their conservational significance. Oikos 63:19-28

Ghose S (2015) LouisvilleKy.gov. http://louisvilleky.gov/. Accessed 26 August 2015

Gleditsch JM, Carlo TA (2011) Fruit quantity of invasive shrubs predicts the adundance of common native avian frugivores in central Pennsylvania. Divers Distrib $17: 244-253$

Goodnight J, Barr AJ, John S (2015) SAS Institute Inc. Version 9.4. Cary, NC

Gorchov DL, Trisel DE (2003) Competitive effects of the invasive shrub, Lonicera maackii (Rupr.) Herder (Caprifoliaceae), on the growth and survival of native tree seedlings. Plant Ecol 166:13-24

Gould AA, Gorchov DL (2000) Effects of the exotic invasive shrub Lonicera maackii on the survival and fecundity of three species of native annual herbs. Am Midl Nat $144: 36-50$

Greenberg CH, Smith LM, Levey DJ (2001) Fruit fate, seed germination, and growth of an invasive vine: an experimental test of 'sit and wait' strategy. Biol Invasions $3: 363-372$

Hartman KM, McCarthy BC (2004) Restoration of forest understory after removal of an invasive shrub, Amur honeysuckle (Lonicera maackii). Restor Ecol 12: 154-165

Heip CHR, Herman PMJ, Soetaert K (1998) Indices of diversity and evenness. Océanis 24: $61-87$

Hill MO (1973) Diversity and evenness: a unifying notation and its consequences. Ecology 54: 427-432 
Hutchinson TF, Vankat, JL (1997) Invasibility and effects of Amur honeysuckle in southwestern Ohio forests. Conserv Biol 11:1117-1124

Ingold JL, Craycraft MJ (1983) Avian frugivory on honeysuckle (Lonicera) in southwestern Ohio in fall. Ohio J Sci 83:256-258

International Union for Conservation of Nature (IUCN) Species Survival Commission (2009) Wildlife in a changing world: an analysis of the 2008 IUCN red list of threatened species. IUCN, Gland Switzerland

James FC, Rathbun S (1981) Rarefaction, relative abundance, and diversity of avian communities. The Auk 98:785-800

James FC, Wamer NO (1982) Relationships between temperate forest bird communities and vegetation structure. Ecology 63:159-171

Jones TM, Rodewald AD, Shustack DP (2010) Variation in plumage colorization of Northern cardinals in urbanizing landscapes. Wilson J Ornithol 122:326-333

Josey DA (2015) Blackacre Conservancy, Inc. http://blackacreconservancy.org/. Accessed 5 August 2015

Keane RM, Crawley MJ (2002) Exotic plant invasions and the enemy release hypothesis. Trends Ecol Evol 17:164-170

Khanaposhtani MG, Kaboli M, Karami M, Etemad V (2012) Effect of habitat complexity on richness, abundance and distributional pattern of forest birds. Environ Manage 50:296-303

Kimball S (2015) U.S. Geological Survey. http://www.usgs.gov/. Accessed 5 June 2015

Kistler S (2015) Kentucky Ornithological Society. http://www.birdky.org/. Accessed 9 July 2015

Kottek M (2014) World Maps of Köppen-Geiger climate classification. http://koeppengeiger.vu-wien.ac.at/. Accessed 15 January 2014

Krebs CJ (1999) Ecological Methodology, $2^{\text {nd }}$ edn. Benjamin-Cummings, California

Lieurance D, Cipollini D (2012) Damage levels from arthropod herbivores on Lonicera maackii suggest enemy release in its introduced range. Biol Invasions 14:863-873

Lieurance D, Chakraborty S, Whitehead SR et al (2015) Comparative herbivory rates and secondary metabolite profiles in the leaves of native and non-native Lonicera species 41:1069-1079 
Liu Z, He C, Wu J (2016) The relationship between habitat loss and fragmentation during urbanization: an empirical evaluation from 16 world cities. Plos One. doi: 0.1371/ journal.pone.0154613

Lodge DM, Williams S, MacIsaac HJ et al (2006) Biological invasions: recommendations for U.S. policy and management. Ecol Appl 16:2035-2054

Loomis JD, Cameron GN (2014) Impact of the ivasive shrub Amur honeysuckle (Lonicera maackii) on shrub layer insects in a deciduous forest in the eastern United States. Biol Invasions 16:89-100

Luken JO, Goessling N (1995) Seedling distribution and potential persistance of the exotic shrub Lonicer maackii in fragmented forests. Am Midl Nat 133:124-130

Luken JO, Tholemier TC, Kuddes LM, Kundel BA (1995) Performance, plasticity, and acclimation of the nonindigenous shrub Lonicera maackii (Caprifoliaceae) in contrasting light environments. Can J Botany 73:1953-1961

Luken JO, Thieret JW (1996) Amur honeysuckle, it fall from grace. BioScience 46:18-24

Luken JO, Mattimiro DT (1997) Habitat-specific resilience of the invasive shrub Amur honeysuckle (Lonicera maackii) during repeated clippings. Ecol Appl 1:104-109

MacArthur RH, MacArthur JW (1961) On bird species diversity. Ecology 42:594-598

MacArthur RH (1964) Environmental factors affecting bird species diversity. Am Nat 98:387-397

Mainka SA, Howard GW (2010) Climate change and invasive species: double jeopardy. Integrative Zoology 5:102:111

Marzluff JM (2005) Island biogeography for an urbanizing world: how extinction and colonization may determine biological diversity in human-dominated landscapes. Urban Ecosystems 8:1557-177

Masters JA (2014) Invasive plants as drivers and passengers of community change in a disturbed urban forest. Dissertation, University of Louisville

McCune B, Mefford MJ (2006) PC-ORD Multivariate analysis of ecological data Version 5. Gleneden Beach, Oregon

McCuster EC, Ward MP, Brawn JD (2010) Seasonal responses of avian communities to invasive bush honeysuckles (Lonicera spp.). Biol Invasions 12:2459-2470 
McEvoy NL, Durtsche RD (2004) Effect of the invasive shrub Lonicera maackii (Caprifoliaceae; Amur honeysuckle) on autumn herpetofauna biodiversity. Journal of the Kentucky Academy of Science 65:27-32

McEwan RW, Arthur-Paratley LG, Rieske LK, Arthur MA (2010) A multi-assay comparison of seed germination inhibition by Lonicera maackii and co-occuring native shrubs. Flora 205:475-483

McEwan RW, Arthur MA, Alverson SE (2012) Throughfall chenistry and soil nutrient effects of the invasive shrub Lonicera maackii in deciduous forests. Am Midl Nat 168:43-55

McNeish RE, Benbow ME, McEwan RW (2012) Riparian forest invasion by a terrestrial shrub (Lonicera maackii) impacts aquatic biota and organic matter processing in headwater streams. Biol Invasions 14:1881-1893

Melles S, Glenn S, Martin K (2003) Urban bird diversity and landscape complexity: species-environment associations along a multiscale habitat gradient. Conserv Ecol 7:5

Montaldo NH (2000) Reproductive success of bird-dispersed plants in a subtropical forest relict in Argentina. Rev Chil Hist Nat 73: 511-524

Moondog P (2016) Observatory History. http://www.astro.louisville.edu/. Accessed 19 March 2008

Ortega-Álvarez R, MacGregor-Fors I (2009) Living in the big city: effects of urban landuse on bird community structure, diversity, and composition. Landscape and Urban Planning 90:189-195

Parmesan C, Yohe G (2003) A globally coherent fingerprint of climate change impacts across natural systems. Nature 421:37-42

Pipal R (2014) Earthworm, microbial biomass, and leaf litter decay responses after invasive honeysuckle shrub removal from urban woodlands. Dissertation, University of Louisville

Poole AF, Bierregaard RO, Martell MS (2005) The Birds of North America. Ithaca, New York

Pyle P, DeSante DF (2014) The institute for bird populations. www.birdpop.org. Accessed 15 December 2014 
Richardson DM, Rejmánek M (2011) Tree and shrubs as invasive alien species-a global review. Divers Distrib 17:788-809

Rodewald AD, Shustack DP, Hitchcock LE (2010) Exotic shrubs as ephemeral ecological traps for nesting birds. Biol Invasions 12:33-39

Rodewald AD (2012) Spreading messages about invasives. Divers Distrib 18:97-99

Rottenburn SC (1998) Predicting the impacts of urbanization on riparian bird communities. Biological Urbanization 88: 289-299

Sallabanks R (1993) Fruiting plant attractiveness to avian seed dispersers: native vs. invasive Crataegus in western Oregon. Madroño 40:108-116

Schmidt KA, Whelan CJ (1999) Effects of exotic Lonicera and Rhamnus on songbird nest predation. Conserv Biol 13:1502-1506

Sibley DA (2003) The Sibley Field Guide to Birds of Eastern North America. Knopf, New York.

Simberloff D (2013) What everyone needs to know about invasive species. Oxford University Press, New York

Share A (1976) Restoration of a tornado ravaged park. Landscape Archit 66: 456-62

Smith PGR (2003) Winter bird use of urban and rural habitats in Ontario. Can Field Nat 117:173-183

Tercek M (2016) The Nature Conservancy. http://www.nature.org/. Accessed 10 March 2016

Trammell T, Carreiro M (2011) Vegetation composition and structure of woody plant communities along urban interstate corridors in Louisville, KY, U.S.A. Urban Ecosystems 14:501-524

Trammell T, Ralston H, Scroggins S, Carreiro M (2012) Foliar production and decomposition rates in urban forests invaded by the exotic invasive shrub, Lonicera maackii. Biol Invasions 14:529-545

Townsend CR, Scarsbrook MR (1997) The intermediate disturbance hypothesis, refugia, and biodiversity in streams. Limnol Oceanogr 42:938-949 
Vila M, D'Antonio CM (1998) Fruit choice and seed dispersal of invasive vs. noninvasive Carpobrotus (Aizoaceae) in coastal California. Ecology 79:10531060

Vilsack T (2015) United States Department of Agriculture. http://usda.gov/java/nxCompsite. Accessed 18 May 2015

Watling JI, Orrock JL (2010) Measuring edge contrast using biotic criteria helps define edge effects on the density of an invasive plant. Landscape Ecol 25:69-78

Watling JI, Hickman CR, Orrock JL (2011) Invasive shrub alters native forest amphibian communities. Biol Conserv 144:2597-2601

Wenner C (2013) Effects of honeysuckle (Lonicera maackii) management on avian abundance. Thesis, Ohio State University

Whittaker R (1975) Communities and ecosystems. Macmillan, New York

White R, Carreiro M, Zipperer W (2014) Woody plant communities along urban, suburban, and rural streams in Louisville, Kentucky, USA. Urban Ecosystems. doi: 10.1007/s11252-014-0376-X

Wilson HN, Arthur MA, Schorgendorfer A, Paratley RD, Lee BD, McEwan RW (2013) Site characteristics as predictors of Lonicera maackii in second-growth forests of central Kentucky, USA. Nat Area J 33:189-198

Woods K (1993) Effects of invasion by Lonicera tatarica L. on herbs and tree seedlings in four New England Forests. Am Midl Nat 130:62-74

Yarnold D (2015) Audubon Magazine. http://www.audubon.org/magazine. Accessed 16 March 2016

Yost L (2015) United States Board on Geographic Names. http://geonames.usgs.gov/. Accessed 10 August 2015 


\section{APPENDICES}

\section{Appendix 1}

Diagram of vegetation surveys performed at all thirteen forest stands. A one kilometer trail used in each stand was broken down into ten transects, each starting 50 meters into the trail and spaced 100 meters apart. These transects were perpendicular to the trail and were 40 meters in length ( 20 meters from the center of the trail on both sides). Measuring tape was extended 20 meters from the center of the trail on each side of the trail and trees or shrubs above two meters tall extending over the transect were identified. The percentage of each functional type of groundcover was measured using $1 \mathrm{~m}^{2}$ quadrats every 10 meters along each transect. The location of each $1 \mathrm{~m}^{2}$ quadrat was determined by a random number generator and was measured on alternate sides of the transect; a total of 10 quadrat measurements were taken at each transect (represented by X's on the diagram). Percent canopy cover was measured every 10 meters along each transect using a densiometer. A total of four canopy cover readings were taken every 90 degrees at each 10-meter interval along each transect (represented by D's on the diagram). 


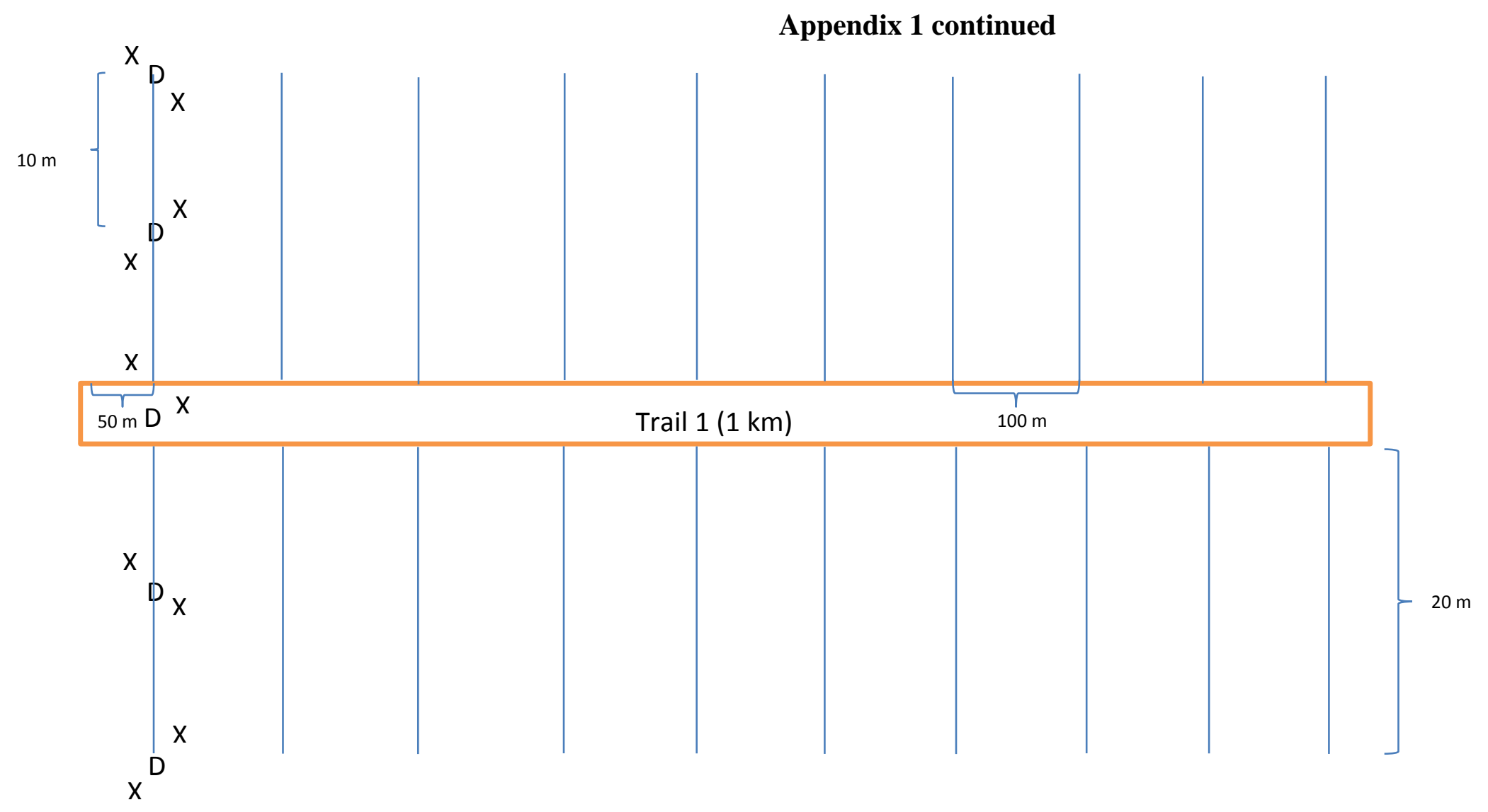




\section{Appendix 2}

Information from the vegetation surveys and alpha diversity results for the 13 forest stands. 'AI' is anthropogenic index (value ranging from 0 to 100 indicating extent of human impact). Alpha diversity measurements of stand vegetation composition included genera richness, Shannon diversity indices $\left(\mathrm{H}, \mathrm{H}=-\Sigma p_{i}\left(\ln p_{i}\right)\right)$, Simpson diversity indices $\left(\mathrm{D}, \mathrm{D}=\Sigma\left(p_{i}\right)^{2}\right)$, a measure of evenness generated from the Shannon diversity index $\left(\mathrm{E}_{\mathrm{H}}, \mathrm{E}_{\mathrm{H}}=[-\Sigma p i \ln p i] / \ln \mathrm{S}\right), \mathrm{N}_{1}$, and $\mathrm{N}_{2}\left(\mathrm{~N}_{1}=\mathrm{e}^{\mathrm{H}}\right.$ and $\left.\mathrm{N}_{2}=1 / \mathrm{D}\right)$.

\begin{tabular}{|c|c|c|c|c|c|c|c|c|c|c|c|c|c|}
\hline $\begin{array}{l}\text { Forest } \\
\text { Stand }\end{array}$ & $\begin{array}{l}\text { Cherokee } \\
\text { Park (CP) }\end{array}$ & $\begin{array}{l}\text { Iroquois } \\
\text { Park (IP) }\end{array}$ & $\begin{array}{c}\text { Jefferson } \\
\text { Mem-orial } \\
\text { Forest } \\
(\mathrm{JMF})\end{array}$ & $\begin{array}{l}\text { Horner } \\
\text { Preserve } \\
\text { (HP) }\end{array}$ & $\begin{array}{l}\text { Mt. St. } \\
\text { Francis } \\
\text { Seminary } \\
\text { (MSF) }\end{array}$ & $\begin{array}{l}\text { Charles } \\
\text {-town } \\
\text { State } \\
\text { Park } \\
\text { (CSP) }\end{array}$ & $\begin{array}{l}\text { Lapping } \\
\text { Park } \\
\text { (LP) }\end{array}$ & $\begin{array}{l}\text { McNeely } \\
\text { Lake Park } \\
\text { (MP) }\end{array}$ & $\begin{array}{c}\text { Horner } \\
\text { Preserve } \\
(L . \\
\text { maackii) } \\
\text { (HPH) }\end{array}$ & $\begin{array}{l}\text { Black- } \\
\text { acre } \\
\text { Nature } \\
\text { Preserve } \\
\text { (BA) }\end{array}$ & $\begin{array}{l}\text { Charles- } \\
\text { town State } \\
\text { Park (L. } \\
\text { maackii) } \\
\text { (CSPH) }\end{array}$ & $\begin{array}{l}\text { Joe } \\
\text { Creason } \\
\text { (JC) }\end{array}$ & $\begin{array}{c}\text { E.P. } \\
\text { "Tom" } \\
\text { Sawyer } \\
\text { (TS) }\end{array}$ \\
\hline $\begin{array}{l}\text { Tree genera } \\
\text { richness }\end{array}$ & 20 & 18 & 17 & 18 & 19 & 23 & 19 & 22 & 26 & 24 & 25 & 19 & 22 \\
\hline AI & 37 & 38 & 15 & 2 & 1 & 0 & 22 & 19 & 1 & 16 & 0 & 28 & 16 \\
\hline $\begin{array}{l}\% \text { Honey- } \\
\text { suckle } \\
\text { cover }\end{array}$ & 0.00 & 0.00 & 0.00 & 0.00 & 0.00 & 0.75 & 0.95 & 10.30 & 13.90 & 18.43 & 28.98 & 43.20 & 50.05 \\
\hline $\begin{array}{c}\text { Mean tree } \\
\text { ht. }\end{array}$ & 13.60 & 10.37 & 11.85 & 14.67 & 12.27 & 10.24 & 15.04 & 7.36 & 7.71 & 9.39 & 8.40 & 7.48 & 9.44 \\
\hline $\begin{array}{l}\text { Genus with } \\
\text { highest \% } \\
\text { cover }\end{array}$ & $\begin{array}{l}\text { maple } \\
\text { (Acer) } \\
100.01\end{array}$ & $\begin{array}{l}\text { maple } \\
\text { (Acer) } \\
59.38\end{array}$ & $\begin{array}{c}\text { oak } \\
\text { (Quercus) } \\
62.65\end{array}$ & $\begin{array}{l}\text { maple } \\
\text { (Acer) } \\
101.70\end{array}$ & $\begin{array}{l}\text { maple } \\
(\text { Acer }) \\
74.30\end{array}$ & $\begin{array}{c}\text { maple } \\
(\text { Acer }) \\
73.38\end{array}$ & $\begin{array}{l}\text { maple } \\
(\text { Acer }) \\
71.58\end{array}$ & $\begin{array}{c}\text { cedar } \\
\text { (Juniperus) } \\
30.95\end{array}$ & $\begin{array}{l}\text { cedar } \\
(\text { Juni- } \\
\text { perus }) \\
30.25\end{array}$ & $\begin{array}{c}\text { maple } \\
\text { (Acer) } \\
51.68\end{array}$ & $\begin{array}{c}\text { maple } \\
(\text { Acer }) \\
46.85\end{array}$ & $\begin{array}{l}\text { honey- } \\
\text { suckle } \\
\text { (Loni- } \\
\text { cera) } \\
43.20 \\
\end{array}$ & $\begin{array}{c}\text { honey- } \\
\text { suckle } \\
\text { (Loni- } \\
\text { cera) } \\
50.05\end{array}$ \\
\hline
\end{tabular}




\section{Appendix 2 continued}

\begin{tabular}{|c|c|c|c|c|c|c|c|c|c|c|c|c|c|}
\hline $\begin{array}{l}\text { Forest } \\
\text { Stand }\end{array}$ & $\begin{array}{l}\text { Cherokee } \\
\text { Park (CP) }\end{array}$ & $\begin{array}{l}\text { Iroquois } \\
\text { Park (IP) }\end{array}$ & $\begin{array}{c}\text { Jefferson } \\
\text { Mem-orial } \\
\text { Forest } \\
(\mathrm{JMF})\end{array}$ & $\begin{array}{l}\text { Horner } \\
\text { Preserve } \\
\text { (HP) }\end{array}$ & $\begin{array}{l}\text { Mt. St. } \\
\text { Francis } \\
\text { Seminary } \\
\text { (MSF) }\end{array}$ & $\begin{array}{c}\text { Charles } \\
\text {-town } \\
\text { State } \\
\text { Park } \\
\text { (CSP) }\end{array}$ & $\begin{array}{l}\text { Lapping } \\
\text { Park } \\
\text { (LP) }\end{array}$ & $\begin{array}{c}\text { McNeely } \\
\text { Lake Park } \\
\text { (MP) }\end{array}$ & $\begin{array}{c}\text { Horner } \\
\text { Preserve } \\
(L . \\
\text { maackii) } \\
\text { (HPH) }\end{array}$ & $\begin{array}{c}\text { Black- } \\
\text { acre } \\
\text { Nature } \\
\text { Preserve } \\
\text { (BA) }\end{array}$ & $\begin{array}{l}\text { Charles- } \\
\text { town State } \\
\text { Park (L. } \\
\text { maackii) } \\
\text { (CSPH) }\end{array}$ & $\begin{array}{c}\text { Joe } \\
\text { Creason } \\
\text { (JC) }\end{array}$ & $\begin{array}{c}\text { E.P. } \\
\text { "Tom" } \\
\text { Sawyer } \\
\text { (TS) }\end{array}$ \\
\hline $\begin{array}{c}\text { Genus with } \\
2 \text { nd highest } \\
\% \text { cover }\end{array}$ & $\begin{array}{c}\text { ash } \\
\text { (Fraxi- } \\
\text { nus) } \\
23.98\end{array}$ & $\begin{array}{c}\text { oak } \\
(\text { Quer- } \\
\text { cus }) \\
50.63\end{array}$ & $\begin{array}{c}\text { maple } \\
(\text { Acer }) \\
13.83\end{array}$ & $\begin{array}{c}\text { ash } \\
\text { (Fraxi- } \\
\text { nus) } \\
37.75\end{array}$ & $\begin{array}{c}\text { ash } \\
\text { (Fraxi- } \\
\text { nus) } \\
28.58\end{array}$ & $\begin{array}{c}\text { ash } \\
\text { (Fraxi- } \\
\text { nus) } \\
23.98\end{array}$ & $\begin{array}{c}\text { spice- } \\
\text { bush } \\
\text { (Lindera) } \\
19.25\end{array}$ & $\begin{array}{c}\text { Oak } \\
\text { (Quercus) } \\
22.10\end{array}$ & $\begin{array}{l}\text { maple } \\
\text { (Acer) } \\
24.05\end{array}$ & $\begin{array}{l}\text { hickory } \\
\text { (Carya) } \\
25.93\end{array}$ & $\begin{array}{c}\text { honey- } \\
\text { suckle } \\
\text { (Lonicera) } \\
28.98\end{array}$ & $\begin{array}{l}\text { maple } \\
\text { (Acer) } \\
31.90\end{array}$ & $\begin{array}{c}\text { locust } \\
\text { (Robin- } \\
\text { ia) } \\
14.88\end{array}$ \\
\hline $\begin{array}{c}\text { Genus with } \\
\text { 3rd highest } \\
\% \text { cover }\end{array}$ & $\begin{array}{c}\text { walnut } \\
\text { (Juglans) } \\
21.05\end{array}$ & $\begin{array}{c}\text { ash } \\
\text { (Fraxi- } \\
\text { nus) } 17.43\end{array}$ & $\begin{array}{c}\text { pine } \\
\text { (Pinus) } \\
11.58\end{array}$ & $\begin{array}{c}\text { walnut } \\
\text { (Juglans) } \\
7.13\end{array}$ & $\begin{array}{c}\text { oak } \\
(\text { Quer- } \\
\text { cus }) \\
24.50\end{array}$ & $\begin{array}{c}\text { oak } \\
(\text { Quer- } \\
\text { cus }) \\
22.00\end{array}$ & $\begin{array}{c}\text { beech } \\
(\text { Fagus }) \\
18.05\end{array}$ & $\begin{array}{l}\text { maple } \\
\text { (Acer) } \\
18.58\end{array}$ & $\begin{array}{c}\text { Osage } \\
\text { Orange } \\
(\text { Mac- } \\
\text { lura }) \\
16.98 \\
\end{array}$ & $\begin{array}{c}\text { oak } \\
(\text { Quer- } \\
\text { cus }) \\
24.35\end{array}$ & $\begin{array}{c}\text { cedar } \\
\text { (Juni- } \\
\text { perus) } \\
21.28\end{array}$ & $\begin{array}{c}\text { pawpaws } \\
\text { (Asimina) } \\
19.30\end{array}$ & $\begin{array}{c}\text { maple } \\
\text { (Acer) } \\
13.73\end{array}$ \\
\hline $\mathrm{N}_{1}$ & 7.23 & 6.63 & 9.01 & 5.10 & 9.09 & 11.05 & 7.24 & 10.01 & 12.09 & 11.47 & 10.68 & 6.11 & 7.63 \\
\hline $\mathrm{E}_{\mathrm{H}}$ & 0.66 & 0.65 & 0.78 & 0.56 & 0.75 & 0.77 & 0.67 & 0.75 & 0.77 & 0.77 & 0.74 & 0.61 & 0.66 \\
\hline $\mathrm{N}_{2}$ & 3.74 & 3.85 & 6.08 & 3.01 & 5.52 & 7.83 & 4.46 & 6.49 & 8.22 & 8.38 & 7.45 & 3.64 & 3.87 \\
\hline $\begin{array}{l}\text { Elevation } \\
\text { (m) }\end{array}$ & 164.60 & 221.0 & 216.1 & 228.0 & 274.8 & 171.1 & 136.7 & 192.3 & 188.7 & 224.40 & 199.1 & 168.3 & 226.3 \\
\hline $\begin{array}{l}\% \text { Bare- } \\
\text { ground }\end{array}$ & 52.24 & 68.50 & 68.21 & 83.44 & 78.32 & 83.47 & 38.97 & 48.96 & 80.67 & 75.21 & 70.73 & 56.58 & 39.91 \\
\hline
\end{tabular}




\section{Appendix 2 continued}

\begin{tabular}{|c|c|c|c|c|c|c|c|c|c|c|c|c|c|}
\hline $\begin{array}{l}\text { Forest } \\
\text { Stand }\end{array}$ & $\begin{array}{l}\text { Cherokee } \\
\text { Park (CP) }\end{array}$ & $\begin{array}{l}\text { Iroquois } \\
\text { Park (IP) }\end{array}$ & $\begin{array}{c}\text { Jefferson } \\
\text { Mem-orial } \\
\text { Forest } \\
\text { (JMF) }\end{array}$ & $\begin{array}{l}\text { Horner } \\
\text { Preserve } \\
\text { (HP) }\end{array}$ & $\begin{array}{l}\text { Mt. St. } \\
\text { Francis } \\
\text { Seminary } \\
\text { (MSF) }\end{array}$ & $\begin{array}{c}\text { Charles } \\
\text {-town } \\
\text { State } \\
\text { Park } \\
\text { (CSP) }\end{array}$ & $\begin{array}{l}\text { Lapping } \\
\text { Park } \\
\text { (LP) }\end{array}$ & $\begin{array}{c}\text { McNeely } \\
\text { Lake Park } \\
\text { (MP) }\end{array}$ & $\begin{array}{c}\text { Horner } \\
\text { Preserve } \\
\text { (L. } \\
\text { maackii) } \\
\text { (HPH) } \\
\end{array}$ & $\begin{array}{c}\text { Black- } \\
\text { acre } \\
\text { Nature } \\
\text { Preserve } \\
\text { (BA) }\end{array}$ & $\begin{array}{c}\text { Charles- } \\
\text { town State } \\
\text { Park (L. } \\
\text { maackii) } \\
\text { (CSPH) }\end{array}$ & $\begin{array}{l}\text { Joe } \\
\text { Creason } \\
\text { (JC) }\end{array}$ & $\begin{array}{c}\text { E.P. } \\
\text { "Tom" } \\
\text { Sawyer } \\
\text { (TS) }\end{array}$ \\
\hline \% Open sky & 13.94 & 10.71 & 27.77 & 18.22 & 18.67 & 22.39 & 13.57 & 26.20 & 24.10 & 22.95 & 18.43 & 17.625 & 21.03 \\
\hline $\begin{array}{c}\text { \% Canopy } \\
\text { cover }\end{array}$ & 86.07 & 89.29 & 72.24 & 81.79 & 81.33 & 77.61 & 86.43 & 73.81 & 75.90 & 77.06 & 81.57 & 82.38 & 78.97 \\
\hline $\begin{array}{c}\% \\
\text { Understory } \\
\text { cover }\end{array}$ & 7.20 & 14.33 & 3.75 & 3.50 & 13.00 & 14.63 & 16.75 & 17.88 & 23.50 & 16.88 & 15.63 & 32.15 & 15.88 \\
\hline
\end{tabular}




\section{Appendix 3}

Alpha diversity results of bird surveys organized by season and year (two study years). Diversity results include bird counts, species richness $(\mathrm{S})$, Shannon diversity indices $\left(\mathrm{H}, \mathrm{H}=-\Sigma p_{i}\left(\ln p_{i}\right)\right)$, Simpson diversity indices $\left(\mathrm{D}, \mathrm{D}=\Sigma\left(p_{i}\right)^{2}\right)$, a measure of evenness generated from the Shannon diversity index $\left(\mathrm{E}_{\mathrm{H}}, \mathrm{E}_{\mathrm{H}}=[-\Sigma p i \ln p i] / \ln \mathrm{S}\right), \mathrm{N}_{1}$, and $\mathrm{N}_{2}\left(\mathrm{~N}_{1}=\mathrm{e}^{\mathrm{H}}\right.$ and $\left.\mathrm{N}_{2}=1 / \mathrm{D}\right)$.

\begin{tabular}{|c|c|c|c|c|c|c|c|c|c|c|c|c|c|}
\hline \multicolumn{10}{|c|}{ Year 1 Winter } \\
\hline Forest stand & CP & IP & JMF & HP & MSF & CSP & LP & MP & HPH & BA & CSPH & JC & TS \\
\hline \% Lonicera & 0.00 & 0.00 & 0.00 & 0.00 & 0.00 & 0.75 & 0.95 & 10.30 & 13.90 & 18.43 & 28.98 & 43.20 & 50.05 \\
\hline Bird counts & 26 & 14 & 41 & 31 & 16 & 22 & 30 & 36 & 16 & 18 & 22 & 32 & 32 \\
\hline S & 10 & 10 & 11 & 8 & 8 & 8 & 10 & 9 & 5 & 9 & 8 & 6 & 9 \\
\hline $\mathrm{H}$ & 2.088 & 2.206 & 2.144 & 1.724 & 1.927 & 1.616 & 1.915 & 1.886 & 1.401 & 1.981 & 1.857 & 1.592 & 1.846 \\
\hline $\mathrm{E}_{\mathrm{H}}$ & 0.907 & 0.958 & 0.894 & 0.829 & 0.927 & 0.777 & 0.832 & 0.859 & 0.871 & 0.902 & 0.893 & 0.889 & 0.840 \\
\hline $\mathrm{N}_{1}$ & 8.069 & 9.079 & 8.534 & 5.607 & 6.869 & 5.033 & 6.787 & 6.593 & 4.059 & 7.250 & 6.404 & 4.914 & 6.334 \\
\hline $\mathrm{D}$ & 0.145 & 0.122 & 0.142 & 0.238 & 0.164 & 0.293 & 0.187 & 0.188 & 0.289 & 0.167 & 0.186 & 0.234 & 0.193 \\
\hline $\mathrm{N}_{2}$ & 6.897 & 8.170 & 7.032 & 4.196 & 6.094 & 3.408 & 5.356 & 5.311 & 3.459 & 5.999 & 5.376 & 4.266 & 5.171 \\
\hline
\end{tabular}




\section{Appendix 3 continued}

\begin{tabular}{|c|c|c|c|c|c|c|c|c|c|c|c|c|c|}
\hline \multicolumn{14}{|c|}{ Year 1 Spring } \\
\hline Forest stand & $\mathrm{CP}$ & IP & JMF & HP & MSF & CSP & LP & MP & $\mathrm{HPH}$ & BA & $\mathrm{CSPH}$ & $\mathrm{JC}$ & $\mathrm{TS}$ \\
\hline$\%$ Lonicera & 0.00 & 0.00 & 0.00 & 0.00 & 0.00 & 0.75 & 0.95 & 10.30 & 13.90 & 18.43 & 28.98 & 43.20 & 50.05 \\
\hline Bird counts & 48 & 52 & 29 & 38 & 59 & 51 & 63 & 87 & 59 & 65 & 58 & 61 & 81 \\
\hline $\mathrm{S}$ & 12 & 14 & 11 & 11 & 12 & 15 & 16 & 19 & 12 & 16 & 13 & 14 & 12 \\
\hline $\mathrm{H}$ & 2.053 & 2.395 & 2.271 & 2.229 & 2.143 & 2.417 & 2.513 & 2.434 & 2.252 & 2.133 & 2.189 & 2.244 & 1.832 \\
\hline $\mathrm{E}_{\mathrm{H}}$ & 0.826 & 0.908 & 0.947 & 0.930 & 0.863 & 0.892 & 0.906 & 0.827 & 0.906 & 0.769 & 0.854 & 0.850 & 0.737 \\
\hline $\mathrm{N}_{1}$ & 7.791 & 10.968 & 9.689 & 9.291 & 8.525 & 11.212 & 12.342 & 11.404 & 9.507 & 8.440 & 8.926 & 9.431 & 6.246 \\
\hline $\mathrm{D}$ & 0.175 & 0.107 & 0.113 & 0.130 & 0.149 & 0.112 & 0.099 & 0.138 & 0.127 & 0.201 & 0.164 & 0.141 & 0.259 \\
\hline $\mathrm{N}_{2}$ & 5.705 & 9.328 & 8.850 & 7.680 & 6.734 & 8.937 & 10.151 & 7.273 & 7.893 & 4.988 & 6.094 & 7.112 & 3.867 \\
\hline
\end{tabular}




\section{Appendix 3 continued}

\begin{tabular}{|c|c|c|c|c|c|c|c|c|c|c|c|c|c|}
\hline \multicolumn{10}{|c|}{ Year 1 Summer } \\
\hline Forest stand & CP & IP & JMF & HP & MSF & CSP & LP & MP & HPH & BA & CSPH & JC & TS \\
\hline \% Lonicera & 0.00 & 0.00 & 0.00 & 0.00 & 0.00 & 0.75 & 0.95 & 10.30 & 13.90 & 18.43 & 28.98 & 43.20 & 50.05 \\
\hline Bird counts & 71 & 44 & 34 & 76 & 48 & 28 & 45 & 36 & 68 & 46 & 70 & 79 & 56 \\
\hline $\mathrm{S}$ & 9 & 15 & 12 & 11 & 11 & 10 & 12 & 8 & 11 & 12 & 13 & 12 & 10 \\
\hline $\mathrm{H}$ & 1.433 & 2.309 & 2.298 & 2.098 & 2.075 & 2.107 & 1.953 & 1.719 & 2.034 & 2.231 & 2.172 & 2.031 & 1.793 \\
\hline $\mathrm{E}_{\mathrm{H}}$ & 0.652 & 0.853 & 0.925 & 0.875 & 0.865 & 0.915 & 0.786 & 0.827 & 0.848 & 0.898 & 0.847 & 0.818 & 0.779 \\
\hline $\mathrm{N}_{1}$ & 4.191 & 10.064 & 9.954 & 8.150 & 7.965 & 8.224 & 7.050 & 5.579 & 7.645 & 9.309 & 8.776 & 7.622 & 6.007 \\
\hline $\mathrm{D}$ & 0.333 & 0.154 & 0.114 & 0.151 & 0.153 & 0.148 & 0.202 & 0.232 & 0.165 & 0.139 & 0.136 & 0.183 & 0.247 \\
\hline $\mathrm{N}_{2}$ & 3.002 & 6.498 & 8.757 & 6.609 & 6.545 & 6.757 & 4.950 & 4.320 & 6.053 & 7.199 & 7.380 & 5.479 & 4.042 \\
\hline
\end{tabular}




\section{Appendix 3 continued}

\begin{tabular}{|c|c|c|c|c|c|c|c|c|c|c|c|c|c|}
\hline \multicolumn{10}{|c|}{ Year 1 Fall } \\
\hline Forest stand & CP & IP & JMF & HP & MSF & CSP & LP & MP & HPH & BA & CSPH & JC & TS \\
\hline \% Lonicera & 0.00 & 0.00 & 0.00 & 0.00 & 0.00 & 0.75 & 0.95 & 10.30 & 13.90 & 18.43 & 28.98 & 43.20 & 50.05 \\
\hline Bird counts & 43 & 33 & 29 & 31 & 39 & 48 & 55 & 69 & 35 & 31 & 55 & 53 & 40 \\
\hline S & 10 & 4 & 9 & 9 & 12 & 14 & 9 & 13 & 11 & 7 & 16 & 10 & 10 \\
\hline $\mathrm{H}$ & 2.179 & 1.281 & 1.779 & 1.983 & 2.283 & 2.354 & 1.972 & 2.024 & 2.051 & 1.578 & 2.459 & 1.959 & 1.829 \\
\hline $\mathrm{E}_{\mathrm{H}}$ & 0.946 & 0.924 & 0.810 & 0.903 & 0.919 & 0.892 & 0.898 & 0.789 & 0.855 & 0.811 & 0.887 & 0.851 & 0.794 \\
\hline $\mathrm{N}_{1}$ & 8.837 & 3.600 & 5.924 & 7.265 & 9.806 & 10.528 & 7.185 & 7.569 & 7.776 & 4.845 & 11.693 & 7.092 & 6.228 \\
\hline $\mathrm{D}$ & 0.126 & 0.297 & 0.227 & 0.163 & 0.118 & 0.115 & 0.168 & 0.178 & 0.167 & 0.253 & 0.107 & 0.173 & 0.211 \\
\hline $\mathrm{N}_{2}$ & 7.937 & 3.372 & 4.403 & 6.120 & 8.496 & 8.726 & 5.942 & 5.609 & 5.977 & 3.954 & 9.311 & 5.767 & 4.735 \\
\hline
\end{tabular}




\section{Appendix 3 continued}

\begin{tabular}{|c|c|c|c|c|c|c|c|c|c|c|c|c|c|}
\hline \multicolumn{10}{|c|}{ Year 2 Winter } \\
\hline Forest stand & CP & IP & JMF & HP & MSF & CSP & LP & MP & HPH & BA & CSPH & JC & TS \\
\hline \% Lonicera & 0.00 & 0.00 & 0.00 & 0.00 & 0.00 & 0.75 & 0.95 & 10.30 & 13.90 & 18.43 & 28.98 & 43.20 & 50.05 \\
\hline Bird counts & 52 & 32 & 29 & 26 & 13 & 14 & 22 & 17 & 11 & 29 & 19 & 58 & 40 \\
\hline S & 11 & 8 & 11 & 10 & 7 & 8 & 9 & 8 & 6 & 6 & 7 & 13 & 9 \\
\hline $\mathrm{H}$ & 2.136 & 1.750 & 2.268 & 2.012 & 1.733 & 1.969 & 2.011 & 1.588 & 1.594 & 1.473 & 1.486 & 2.257 & 1.794 \\
\hline $\mathrm{E}_{\mathrm{H}}$ & 0.891 & 0.841 & 0.946 & 0.874 & 0.890 & 0.947 & 0.916 & 0.764 & 0.890 & 0.822 & 0.764 & 0.880 & 0.817 \\
\hline $\mathrm{N}_{1}$ & 8.466 & 5.755 & 9.660 & 7.478 & 5.658 & 7.164 & 7.471 & 4.894 & 4.923 & 4.362 & 4.419 & 9.554 & 6.013 \\
\hline $\mathrm{D}$ & 0.136 & 0.229 & 0.115 & 0.160 & 0.219 & 0.156 & 0.157 & 0.315 & 0.240 & 0.287 & 0.324 & 0.131 & 0.213 \\
\hline $\mathrm{N}_{2}$ & 7.348 & 4.376 & 8.673 & 6.258 & 4.568 & 6.427 & 6.369 & 3.176 & 4.172 & 3.489 & 3.085 & 7.645 & 4.706 \\
\hline
\end{tabular}




\section{Appendix 3 continued}

\begin{tabular}{|c|c|c|c|c|c|c|c|c|c|c|c|c|c|}
\hline \multicolumn{14}{|c|}{ Year 2 Spring } \\
\hline $\begin{array}{l}\text { Forest } \\
\text { stand }\end{array}$ & $\mathrm{CP}$ & IP & $\mathrm{JMF}$ & HP & MSF & CSP & LP & MP & $\mathrm{HPH}$ & BA & $\mathrm{CSPH}$ & $\mathrm{JC}$ & $\mathrm{TS}$ \\
\hline $\begin{array}{c}\% \\
\text { Lonicera }\end{array}$ & 0.00 & 0.00 & 0.00 & 0.00 & 0.00 & 0.75 & 0.95 & 10.30 & 13.90 & 18.43 & 28.98 & 43.20 & 50.05 \\
\hline $\begin{array}{c}\text { Bird } \\
\text { counts }\end{array}$ & 61 & 80 & 47 & 39 & 44 & 42 & 46 & 70 & 45 & 57 & 47 & 83 & 79 \\
\hline $\mathrm{S}$ & 17 & 18 & 18 & 16 & 21 & 16 & 18 & 14 & 14 & 14 & 16 & 19 & 13 \\
\hline $\mathrm{H}$ & 2.356 & 2.543 & 2.618 & 2.550 & 2.823 & 2.536 & 2.655 & 2.037 & 2.385 & 2.346 & 2.470 & 2.521 & 1.975 \\
\hline $\mathrm{E}_{\mathrm{H}}$ & 0.832 & 0.880 & 0.906 & 0.920 & 0.927 & 0.915 & 0.919 & 0.772 & 0.904 & 0.889 & 0.891 & 0.856 & 0.770 \\
\hline $\mathrm{N}_{1}$ & 10.549 & 12.718 & 13.708 & 12.807 & 16.827 & 12.629 & 14.225 & 7.668 & 10.859 & 10.444 & 11.822 & 12.441 & 7.207 \\
\hline $\mathrm{D}$ & 0.135 & 0.098 & 0.091 & 0.094 & 0.072 & 0.092 & 0.085 & 0.206 & 0.109 & 0.125 & 0.106 & 0.122 & 0.218 \\
\hline $\mathrm{N}_{2}$ & 7.396 & 10.224 & 10.990 & 10.636 & 13.829 & 10.889 & 11.755 & 4.861 & 9.166 & 7.981 & 9.479 & 8.170 & 4.591 \\
\hline
\end{tabular}




\section{Appendix 3 continued}

\begin{tabular}{|c|c|c|c|c|c|c|c|c|c|c|c|c|c|}
\hline \multicolumn{14}{|c|}{ Year 2 Summer } \\
\hline Forest stand & $\mathrm{CP}$ & IP & JMF & HP & MSF & CSP & LP & MP & $\mathrm{HPH}$ & BA & $\mathrm{CSPH}$ & $\mathrm{JC}$ & $\mathrm{TS}$ \\
\hline$\%$ Lonicera & 0.00 & 0.00 & 0.00 & 0.00 & 0.00 & 0.75 & 0.95 & 10.30 & 13.90 & 18.43 & 28.98 & 43.20 & 50.05 \\
\hline Bird counts & 65 & 47 & 17 & 77 & 26 & 36 & 41 & 43 & 38 & 45 & 29 & 53 & 60 \\
\hline $\mathrm{S}$ & 16 & 14 & 10 & 15 & 15 & 13 & 13 & 12 & 8 & 8 & 10 & 13 & 14 \\
\hline $\mathrm{H}$ & 1.997 & 2.313 & 1.950 & 2.129 & 2.631 & 2.385 & 2.372 & 2.078 & 1.674 & 1.721 & 2.038 & 2.040 & 2.194 \\
\hline $\mathrm{E}_{\mathrm{H}}$ & 0.720 & 0.876 & 0.847 & 0.786 & 0.972 & 0.930 & 0.925 & 0.836 & 0.805 & 0.828 & 0.885 & 0.796 & 0.832 \\
\hline $\mathrm{N}_{1}$ & 7.367 & 10.105 & 7.029 & 8.406 & 13.888 & 10.859 & 10.719 & 7.988 & 5.333 & 5.590 & 7.675 & 7.691 & 8.971 \\
\hline $\mathrm{D}$ & 0.231 & 0.132 & 0.211 & 0.194 & 0.077 & 0.105 & 0.109 & 0.173 & 0.240 & 0.231 & 0.158 & 0.186 & 0.153 \\
\hline $\mathrm{N}_{2}$ & 4.333 & 7.593 & 4.737 & 5.160 & 13.001 & 9.533 & 9.183 & 5.797 & 4.174 & 4.337 & 6.325 & 5.391 & 6.545 \\
\hline
\end{tabular}




\section{Appendix 3 continued}

\begin{tabular}{|c|c|c|c|c|c|c|c|c|c|c|c|c|c|}
\hline \multicolumn{14}{|c|}{ Year 2 Fall } \\
\hline Forest stand & $\mathrm{CP}$ & IP & JMF & HP & MSF & CSP & LP & MP & $\mathrm{HPH}$ & $\mathrm{BA}$ & CSPH & $\mathrm{JC}$ & TS \\
\hline \% Lonicera & 0.00 & 0.00 & 0.00 & 0.00 & 0.00 & 0.75 & 0.95 & 10.30 & 13.90 & 18.43 & 28.98 & 43.20 & 50.05 \\
\hline Bird counts & 24 & 29 & 37 & 37 & 37 & 25 & 49 & 55 & 74 & 57 & 39 & 30 & 43 \\
\hline $\mathrm{S}$ & 10 & 11 & 15 & 10 & 9 & 10 & 11 & 14 & 13 & 14 & 9 & 9 & 12 \\
\hline $\mathrm{H}$ & 1.848 & 2.172 & 2.571 & 2.102 & 1.993 & 2.248 & 2.143 & 2.355 & 1.781 & 2.305 & 1.971 & 1.881 & 2.266 \\
\hline $\mathrm{E}_{\mathrm{H}}$ & 0.803 & 0.906 & 0.950 & 0.913 & 0.907 & 0.976 & 0.894 & 0.892 & 0.694 & 0.874 & 0.897 & 0.856 & 0.912 \\
\hline $\mathrm{N}_{1}$ & 6.347 & 8.776 & 13.079 & 8.183 & 7.338 & 9.469 & 8.525 & 10.538 & 5.936 & 10.024 & 7.178 & 6.560 & 9.641 \\
\hline $\mathrm{D}$ & 0.247 & 0.137 & 0.085 & 0.144 & 0.153 & 0.110 & 0.133 & 0.119 & 0.278 & 0.124 & 0.158 & 0.211 & 0.121 \\
\hline $\mathrm{N}_{2}$ & 4.057 & 7.315 & 11.701 & 6.949 & 6.549 & 9.058 & 7.524 & 8.425 & 3.602 & 8.065 & 6.313 & 4.737 & 8.292 \\
\hline
\end{tabular}




\section{Appendix 4}

Results of the multiple regression analyses of the effects of percent honeysuckle cover, tree stand diversity $\left(\mathrm{N}_{2}\right)$, mean tree height, anthropogenic index (AI), percent canopy cover, and the interaction between tree stand diversity and mean tree height on bird diversity $\left(\mathrm{N}_{2}\right)$ in all 13 study sites. Parameter Estimates (PE) and R-squared values for effects on bird diversity within each season are provided.

\begin{tabular}{|l|c|c|c|c|c|c|}
\hline & \multicolumn{6}{|c|}{ Bird Diversity } \\
\hline Season & & & winter & spring & summer & fall \\
\hline & $\mathrm{p}$-value & $\mathrm{PE}$ & $\mathrm{r}^{2}$ & $\mathrm{r}^{2}$ & $\mathrm{r}^{2}$ & $\mathrm{r}^{2}$ \\
\hline \% honeysuckle cover & $\mathbf{0 . 0 2 0 8}$ & -0.3235 & 0.0579 & 0.3050 & 0.0554 & 0.0219 \\
\hline tree stand diversity & 0.6086 & 0.0801 & 0.1388 & 0.0001 & 0.0169 & 0.0271 \\
\hline mean tree height & 0.1385 & 0.2510 & 0.1444 & 0.1531 & 0.0208 & 0.0125 \\
\hline anthropogenic index & $\mathbf{0 . 0 4 3 9}$ & -0.2528 & 0.1764 & 0.0278 & 0.1046 & 0.0783 \\
\hline \% canopy cover & 0.4285 & 0.0967 & 0.0356 & 0.0351 & 0.0020 & 0.0382 \\
\hline & $\mathbf{0 . 0 0 0 2}$ & 0.5043 & $\mathrm{X}$ & $\mathrm{X}$ & $\mathrm{X}$ & $\mathrm{X}$ \\
\hline
\end{tabular}




\section{Appendix 5}

The proportion of 43 tree genera (abbreviated) at all 13 forest stands. This information was used for the first matrix in the nonmetric multidimensional scaling (NMDS) analysis of the forest stands.

\begin{tabular}{|l|l|l|l|l|l|l|l|l|l|l|l|l|}
\hline & Acer & Aesc. & Amel. & Aral. & Asim. & Carp. & Cary. & Cata. & Celt. & Cerc. & Corn. & Crat. \\
\hline BA & 0.5168 & 0.0000 & 0.0000 & 0.0000 & 0.0013 & 0.1118 & 0.2593 & 0.0000 & 0.0815 & 0.1198 & 0.0408 & 0.0000 \\
\hline CP & 1.0005 & 0.0975 & 0.0000 & 0.0000 & 0.0000 & 0.0000 & 0.0058 & 0.0000 & 0.0085 & 0.0020 & 0.0000 & 0.0000 \\
\hline CSP & 0.7338 & 0.0238 & 0.0000 & 0.0000 & 0.0688 & 0.0165 & 0.0550 & 0.0025 & 0.0538 & 0.0030 & 0.0063 & 0.0000 \\
\hline CSPH & 0.4685 & 0.0015 & 0.0000 & 0.0008 & 0.0010 & 0.0003 & 0.0000 & 0.0055 & 0.0225 & 0.1978 & 0.0175 & 0.0005 \\
\hline HP & 1.0170 & 0.0000 & 0.0000 & 0.0000 & 0.0025 & 0.0000 & 0.0325 & 0.0000 & 0.0238 & 0.0105 & 0.0000 & 0.0000 \\
\hline HPH & 0.2405 & 0.0000 & 0.0000 & 0.0005 & 0.0265 & 0.0490 & 0.0063 & 0.0000 & 0.0260 & 0.0465 & 0.0043 & 0.0000 \\
\hline IP & 0.5938 & 0.0000 & 0.0733 & 0.0105 & 0.0000 & 0.0395 & 0.0705 & 0.0000 & 0.0023 & 0.0788 & 0.0005 & 0.0000 \\
\hline JC & 0.3190 & 0.0000 & 0.0000 & 0.0000 & 0.1930 & 0.0000 & 0.0938 & 0.0040 & 0.0698 & 0.0000 & 0.0000 & 0.0025 \\
\hline JMF & 0.1383 & 0.0000 & 0.0380 & 0.0000 & 0.0000 & 0.0000 & 0.0385 & 0.0000 & 0.0000 & 0.0150 & 0.0553 & 0.0000 \\
\hline LP & 0.7158 & 0.0000 & 0.0000 & 0.0000 & 0.0000 & 0.0025 & 0.0218 & 0.0000 & 0.0130 & 0.0010 & 0.0000 & 0.0000 \\
\hline MP & 0.1858 & 0.0000 & 0.0000 & 0.0000 & 0.0100 & 0.0170 & 0.0305 & 0.0000 & 0.0078 & 0.0308 & 0.0203 & 0.0000 \\
\hline MSF & 0.7430 & 0.0005 & 0.0000 & 0.0080 & 0.0048 & 0.0105 & 0.0350 & 0.0000 & 0.0000 & 0.0125 & 0.0125 & 0.0000 \\
\hline TS & 0.1373 & 0.0000 & 0.0000 & 0.0000 & 0.0000 & 0.0000 & 0.0363 & 0.0000 & 0.1150 & 0.0000 & 0.0088 & 0.0000 \\
\hline
\end{tabular}




\section{Appendix 5 continued}

\begin{tabular}{|l|c|c|c|c|c|c|c|c|c|c|c|c|}
\hline & Dios. & Fagu. & Frax. & Gled. & Hama. & Ilex & Jugl. & Juni. & Ligu. & Lind. & Liqu. & Liri. \\
\hline BA & 0.0000 & 0.0005 & 0.1240 & 0.0025 & 0.0000 & 0.0000 & 0.0863 & 0.0720 & 0.0035 & 0.0013 & 0.0000 & 0.0175 \\
\hline CP & 0.0000 & 0.1743 & 0.2398 & 0.0000 & 0.0080 & 0.0055 & 0.2105 & 0.0000 & 0.0000 & 0.0278 & 0.0145 & 0.0793 \\
\hline CSP & 0.0000 & 0.0263 & 0.3730 & 0.0000 & 0.0000 & 0.0000 & 0.0425 & 0.0563 & 0.0000 & 0.1365 & 0.0125 & 0.0600 \\
\hline CSPH & 0.0000 & 0.0005 & 0.2043 & 0.0055 & 0.0000 & 0.0000 & 0.1933 & 0.2128 & 0.0293 & 0.0405 & 0.0000 & 0.0000 \\
\hline HP & 0.0000 & 0.0000 & 0.3775 & 0.0125 & 0.0000 & 0.0000 & 0.0713 & 0.0433 & 0.0000 & 0.0040 & 0.0000 & 0.0350 \\
\hline HPH & 0.0000 & 0.0000 & 0.1465 & 0.0038 & 0.0000 & 0.0000 & 0.0790 & 0.3025 & 0.0100 & 0.0395 & 0.0000 & 0.0325 \\
\hline IP & 0.0000 & 0.0065 & 0.1743 & 0.0000 & 0.0000 & 0.0000 & 0.0000 & 0.0043 & 0.0000 & 0.0008 & 0.0000 & 0.0000 \\
\hline JC & 0.0000 & 0.0000 & 0.1718 & 0.0000 & 0.0000 & 0.0000 & 0.0000 & 0.0000 & 0.0233 & 0.0025 & 0.0000 & 0.0075 \\
\hline JMF & 0.0078 & 0.0010 & 0.0488 & 0.0020 & 0.0000 & 0.0000 & 0.0000 & 0.0440 & 0.0000 & 0.0000 & 0.0000 & 0.0020 \\
\hline LP & 0.0000 & 0.1805 & 0.0220 & 0.0000 & 0.0000 & 0.0000 & 0.0288 & 0.0000 & 0.0000 & 0.1925 & 0.1130 & 0.1738 \\
\hline MP & 0.0000 & 0.0000 & 0.1095 & 0.0000 & 0.0000 & 0.0000 & 0.0050 & 0.3095 & 0.0840 & 0.0000 & 0.0000 & 0.0075 \\
\hline MSF & 0.0250 & 0.2858 & 0.0480 & 0.0000 & 0.0000 & 0.0000 & 0.0000 & 0.0218 & 0.0000 & 0.0353 & 0.0000 & 0.0990 \\
\hline TS & 0.0100 & 0.0000 & 0.0268 & 0.0133 & 0.0000 & 0.0000 & 0.1208 & 0.0083 & 0.0105 & 0.0050 & 0.0025 & 0.0455 \\
\hline
\end{tabular}




\section{Appendix 5 continued}

\begin{tabular}{|l|c|c|c|c|c|c|c|c|c|c|c|c|}
\hline & Macl. & Madu. & Moru. & Nyss. & Pinu. & Plan. & Plat. & Popu. & Prun. & Quer. & Rhus & Robi. \\
\hline BA & 0.0000 & 0.0000 & 0.0000 & 0.0000 & 0.0000 & 0.0000 & 0.0100 & 0.0000 & 0.0055 & 0.2435 & 0.0000 & 0.0175 \\
\hline CP & 0.0000 & 0.0000 & 0.0038 & 0.0000 & 0.0000 & 0.0000 & 0.0998 & 0.0000 & 0.1300 & 0.0890 & 0.0000 & 0.0000 \\
\hline CSP & 0.0000 & 0.0000 & 0.0000 & 0.0000 & 0.0000 & 0.0000 & 0.0000 & 0.0000 & 0.0025 & 0.2200 & 0.0175 & 0.0188 \\
\hline CSPH & 0.0275 & 0.0000 & 0.0000 & 0.0000 & 0.0000 & 0.0000 & 0.0050 & 0.0163 & 0.1538 & 0.0038 & 0.0000 & 0.0000 \\
\hline HP & 0.0000 & 0.0000 & 0.0000 & 0.0000 & 0.0248 & 0.0000 & 0.0175 & 0.0000 & 0.0175 & 0.0538 & 0.0000 & 0.0000 \\
\hline HPH & 0.1698 & 0.0000 & 0.0000 & 0.0000 & 0.0175 & 0.0000 & 0.0905 & 0.0013 & 0.0063 & 0.0620 & 0.0015 & 0.0100 \\
\hline IP & 0.0000 & 0.0000 & 0.0000 & 0.0175 & 0.0000 & 0.0000 & 0.0000 & 0.0000 & 0.0068 & 0.5063 & 0.0000 & 0.0010 \\
\hline JC & 0.0000 & 0.0000 & 0.0008 & 0.0000 & 0.0000 & 0.0000 & 0.0375 & 0.0075 & 0.0085 & 0.0000 & 0.0000 & 0.0538 \\
\hline JMF & 0.0000 & 0.0000 & 0.0000 & 0.0000 & 0.1158 & 0.0000 & 0.0000 & 0.0000 & 0.0213 & 0.6265 & 0.0038 & 0.0000 \\
\hline LP & 0.0000 & 0.0000 & 0.0000 & 0.0000 & 0.0000 & 0.0000 & 0.0580 & 0.0000 & 0.0050 & 0.1395 & 0.0000 & 0.0050 \\
\hline MP & 0.0000 & 0.0000 & 0.0038 & 0.0000 & 0.0025 & 0.0000 & 0.0825 & 0.0000 & 0.0258 & 0.2210 & 0.0068 & 0.0000 \\
\hline MSF & 0.0000 & 0.0000 & 0.0000 & 0.0000 & 0.0000 & 0.0000 & 0.0640 & 0.0000 & 0.0198 & 0.2450 & 0.0000 & 0.0000 \\
\hline TS & 0.0100 & 0.0000 & 0.1128 & 0.0000 & 0.0000 & 0.0000 & 0.0300 & 0.0000 & 0.0538 & 0.0000 & 0.0000 & 0.1488 \\
\hline
\end{tabular}


Appendix 5 continued

\begin{tabular}{|l|c|c|c|c|c|c|c|}
\hline & Rosa & Rubu. & Samb. & Sass. & Symp. & Tili. & Ulmu. \\
\hline BA & 0.0010 & 0.0000 & 0.0005 & 0.0000 & 0.0000 & 0.0100 & 0.0883 \\
\hline CP & 0.0000 & 0.0000 & 0.0000 & 0.0100 & 0.0000 & 0.0825 & 0.1540 \\
\hline CSP & 0.0093 & 0.0000 & 0.0000 & 0.0000 & 0.0000 & 0.0000 & 0.1590 \\
\hline CSPH & 0.0438 & 0.0000 & 0.0000 & 0.0000 & 0.0000 & 0.0000 & 0.1178 \\
\hline HP & 0.0003 & 0.0000 & 0.0000 & 0.0000 & 0.0000 & 0.0370 & 0.0188 \\
\hline HPH & 0.0000 & 0.0000 & 0.0000 & 0.0000 & 0.0013 & 0.0000 & 0.0563 \\
\hline IP & 0.0000 & 0.0000 & 0.0000 & 0.0200 & 0.0000 & 0.0000 & 0.0393 \\
\hline JC & 0.0000 & 0.0095 & 0.0000 & 0.0113 & 0.0000 & 0.0000 & 0.0750 \\
\hline JMF & 0.0000 & 0.0000 & 0.0450 & 0.0000 & 0.0000 & 0.0000 & 0.0083 \\
\hline LP & 0.0000 & 0.0008 & 0.0000 & 0.0025 & 0.0000 & 0.0000 & 0.1101 \\
\hline MP & 0.0000 & 0.0000 & 0.0000 & 0.0025 & 0.0000 & 0.0005 & 0.0720 \\
\hline MSF & 0.0000 & 0.0000 & 0.0000 & 0.0573 & 0.0000 & 0.0000 & 0.0683 \\
\hline TS & 0.0050 & 0.0000 & 0.0000 & 0.0000 & 0.0000 & 0.0363 & 0.0885 \\
\hline
\end{tabular}




\section{Appendix 5 continued}

\begin{tabular}{|c|c|c|c|c|c|c|c|c|c|c|c|c|}
\hline BA & $\mathrm{CP}$ & CSP & CSPH & $\mathrm{HP}$ & $\mathrm{HPH}$ & IP & $\mathrm{JC}$ & $\mathrm{JMF}$ & LP & MP & MSF & $\mathrm{TS}$ \\
\hline $\begin{array}{c}\text { Blackacre } \\
\text { Nature } \\
\text { Preserve }\end{array}$ & $\begin{array}{c}\text { Cherokee } \\
\text { Park }\end{array}$ & $\begin{array}{c}\text { Charles- } \\
\text { town State } \\
\text { Park }\end{array}$ & $\begin{array}{l}\text { Charles- } \\
\text { town State } \\
\text { Park }(L . \\
\text { maackii) }\end{array}$ & $\begin{array}{c}\text { Horner } \\
\text { Preserve } \\
\text { (HP) }\end{array}$ & $\begin{array}{c}\text { Horner } \\
\text { Preserve } \\
\quad(L . \\
\text { maackii) }\end{array}$ & $\begin{array}{c}\text { Iroquois } \\
\text { Park }\end{array}$ & $\begin{array}{c}\text { Joe } \\
\text { Creason }\end{array}$ & $\begin{array}{c}\text { Jefferson } \\
\text { Memorial } \\
\text { Forest }\end{array}$ & $\begin{array}{l}\text { Lapping } \\
\text { Park }\end{array}$ & $\begin{array}{c}\text { McNeely } \\
\text { Lake Park }\end{array}$ & $\begin{array}{c}\text { Mt. St. } \\
\text { Francis } \\
\text { Seminary }\end{array}$ & $\begin{array}{c}\text { E.P. Tom } \\
\text { Sawyer }\end{array}$ \\
\hline
\end{tabular}




\section{Appendix 5 continued}

\begin{tabular}{|r|r|}
\hline Acer & Acer \\
\hline Aesc. & Aesculus \\
\hline Amel. & Amelanchier \\
\hline Aral. & Aralia \\
\hline Asim. & Asimina \\
\hline Carp. & Carpinus \\
\hline Cary. & Carya \\
\hline Cata. & Catalpa \\
\hline Celt. & Celtis \\
\hline Cerc. & Cercis \\
\hline Corn. & Cornus \\
\hline Crat. & Crataegus \\
\hline Dios. & Diospyrus \\
\hline Fagu. & Fagus \\
\hline Frax. & Fraxinus \\
\hline Gled. & Gleditsia \\
\hline Hama. & Hamamelis \\
\hline Ilex & Ilex \\
\hline Jugl. & Juglans \\
\hline Juni. & Juniperus \\
\hline Ligu. & Ligustrum \\
\hline Lind. & Lindera \\
\hline Liqu. & Liquidambar \\
\hline Liri. & Liriodendron \\
\hline Macl. & Maclura \\
\hline Madu. & Madura \\
\hline Moru. & Morus \\
\hline Nyss. & Nyssa \\
\hline Pinu. & Pinus \\
\hline Plan. & Planus \\
\hline Plat. & Platanus \\
\hline Popu. & Populus \\
\hline Prun. & Prunus \\
\hline & \\
\hline & \\
\hline & \\
\hline & \\
\hline &
\end{tabular}




\section{Appendix 5 continued}

\begin{tabular}{|r|r|}
\hline Quer. & Quercus \\
\hline Rhus & Rhus \\
\hline Robi. & Robinia \\
\hline Rosa & Rosa \\
\hline Rubu. & Rubus \\
\hline Samb. & Sambucus \\
\hline Sass. & Sassafras \\
\hline Symp. & Symphoricarpos \\
\hline Tili. & Tilia \\
\hline Ulmu. & Ulmus \\
\hline
\end{tabular}


Appendix 6

Attributes of the 13 forest stands used in the second matrix of the nonmetric multidimensional scaling (NMDS) analysis.

\begin{tabular}{|c|c|c|c|c|c|c|c|}
\hline & elevation $(\mathrm{m})$ & $\begin{array}{c}\text { \% bare } \\
\text { ground }\end{array}$ & \% open sky & $\begin{array}{c}\text { \% understory } \\
\text { cover }\end{array}$ & $\begin{array}{c}\text { mean tree } \\
\text { height }\end{array}$ & $\begin{array}{c}\text { mean tree } \\
\text { height } \\
\text { standard } \\
\text { deviation }\end{array}$ & $\begin{array}{c}\text { anthropogenic } \\
\text { index }\end{array}$ \\
\hline BA & 224.4 & 75.21 & 22.95 & 16.88 & 9.39 & 9.40 & 0.16 \\
\hline CP & 164.6 & 52.24 & 13.94 & 7.20 & 13.60 & 10.29 & 0.37 \\
\hline CSP & 171.1 & 83.47 & 22.39 & 14.63 & 10.24 & 10.80 & 0 \\
\hline CSPH & 199.1 & 70.73 & 18.43 & 15.63 & 8.40 & 8.49 & 0 \\
\hline HP & 228.0 & 83.44 & 18.22 & 3.50 & 14.67 & 8.21 & 0.02 \\
\hline HPH & 188.7 & 80.67 & 24.10 & 23.50 & 7.71 & 6.88 & 0.01 \\
\hline IP & 221.0 & 68.50 & 10.71 & 14.33 & 10.37 & 10.56 & 0.38 \\
\hline JC & 168.3 & 56.58 & 17.625 & 32.15 & 7.48 & 8.37 & 0.28 \\
\hline JMF & 216.1 & 68.21 & 27.77 & 3.75 & 11.85 & 9.20 & 0.15 \\
\hline LP & 136.7 & 38.97 & 13.57 & 16.75 & 15.04 & 14.33 & 0.22 \\
\hline MP & 192.3 & 48.96 & 26.20 & 17.88 & 7.36 & 6.45 & 0.19 \\
\hline MSF & 274.8 & 78.32 & 18.67 & 13.00 & 12.27 & 11.32 & 0.01 \\
\hline TS & 226.3 & 39.91 & 21.03 & 15.88 & 9.44 & 8.76 & 0.16 \\
\hline
\end{tabular}




\section{Appendix 7}

Three axes coordinate representing the location of each forest stand within the nonmetric multidimensional scaling (NMDS) ordination. These axes were used in the generalized Poisson regression models to represent compositional aspects of the stands.

\begin{tabular}{|c|c|c|c|}
\hline & Axis 1 & Axis 2 & Axis 3 \\
\hline BA & -0.27371 & -0.02533 & 0.09682 \\
\hline CP & 0.83396 & -0.11219 & -0.45775 \\
\hline CSP & 0.23079 & -0.27133 & -0.48710 \\
\hline CSPH & 0.52700 & 0.57043 & 0.01240 \\
\hline HP & 0.47075 & -0.11844 & -0.65653 \\
\hline HPH & 0.35517 & 0.60060 & 0.64310 \\
\hline JP & -0.41595 & -0.65952 & -0.01089 \\
\hline JMF & -0.54701 & 0.57334 & -0.64022 \\
\hline LP & -1.20575 & -0.84951 & 0.80334 \\
\hline MP & 0.63382 & -0.67485 & -0.25834 \\
\hline MSF & -0.15676 & 0.21277 & 0.85130 \\
\hline
\end{tabular}




\section{Appendix 8}

Parameter estimates (PE), p-values, and FDR p-values of the fixed effects included in the model for the abundance of birds and bird families in all thirteen forest stands within each season for both study years. The Xs represent effects which did not contribute to the model selected based on AIC. Bolded values indicate significance; bolded parameter estimate values indicate the p-value is significant and the FDR p-value may or may not be significant.

\begin{tabular}{|c|c|c|c|c|c|c|c|c|c|c|c|c|}
\hline \multicolumn{13}{|c|}{ Northern cardinal } \\
\hline & \multicolumn{12}{|c|}{ Year 1} \\
\hline & \multicolumn{3}{|c|}{ Winter } & \multicolumn{3}{|c|}{ Spring } & \multicolumn{3}{|c|}{ Summer } & \multicolumn{3}{|c|}{ Fall } \\
\hline & $\mathrm{PE}$ & P-value & $\begin{array}{l}\text { FDR p- } \\
\text { value }\end{array}$ & $\mathrm{PE}$ & P-value & $\begin{array}{l}\text { FDR p- } \\
\text { value }\end{array}$ & PE & P-value & $\begin{array}{l}\text { FDR p- } \\
\text { value }\end{array}$ & $\mathrm{PE}$ & P-value & $\begin{array}{l}\text { FDR p- } \\
\text { value }\end{array}$ \\
\hline $\begin{array}{c}\% \\
\text { honey- } \\
\text { suckle } \\
(\mathrm{HS})\end{array}$ & 0.0842 & 0.7395 & 0.8067 & 0.3248 & 0.0329 & 0.1582 & 0.3030 & 0.0179 & 0.1478 & 0.1203 & 0.5865 & 0.7104 \\
\hline A1 & 0.0107 & 0.9584 & 0.9584 & 0.0788 & 0.4911 & 0.6934 & 0.3420 & 0.0185 & 0.1478 & -0.3160 & 0.1665 & 0.3452 \\
\hline $\mathrm{A} 2$ & $\mathrm{X}$ & $\mathrm{X}$ & $\mathrm{X}$ & $\mathrm{X}$ & $\mathrm{X}$ & $\mathrm{X}$ & $\mathrm{X}$ & $\mathrm{X}$ & $\mathrm{X}$ & $\mathrm{X}$ & $\mathrm{X}$ & $\mathrm{X}$ \\
\hline A3 & $X$ & $X$ & $X$ & $X$ & $\mathrm{X}$ & $X$ & $X$ & $\mathrm{X}$ & $X$ & $\mathrm{X}$ & $X$ & $X$ \\
\hline HS*A1 & -0.2940 & 0.1629 & 0.3452 & -0.0625 & 0.5676 & 0.7104 & -0.1853 & 0.0577 & 0.2306 & 0.3552 & 0.0830 & 0.2845 \\
\hline HS*A2 & $\mathrm{X}$ & $\mathrm{X}$ & $\mathrm{X}$ & $\mathrm{X}$ & $\mathrm{X}$ & $\mathrm{X}$ & $\mathrm{X}$ & $\mathrm{X}$ & $\mathrm{X}$ & $\mathrm{X}$ & $\mathrm{X}$ & $\mathrm{X}$ \\
\hline HS*A3 & $X$ & $\mathrm{X}$ & $X$ & $X$ & $\mathrm{X}$ & $X$ & $X$ & $X$ & $X$ & $X$ & $X$ & $X$ \\
\hline
\end{tabular}




\section{Appendix 8 continued}

\begin{tabular}{|c|c|c|c|c|c|c|c|c|c|c|c|c|}
\hline \multicolumn{13}{|c|}{ Northern cardinal } \\
\hline & \multicolumn{12}{|c|}{ Year 2} \\
\hline & \multicolumn{3}{|c|}{ Winter } & \multicolumn{3}{|c|}{ Spring } & \multicolumn{3}{|c|}{ Summer } & \multicolumn{3}{|c|}{ Fall } \\
\hline & $\mathrm{PE}$ & P-value & $\begin{array}{l}\text { FDR p- } \\
\text { value }\end{array}$ & $\mathrm{PE}$ & P-value & $\begin{array}{l}\text { FDR p- } \\
\text { value }\end{array}$ & $\mathrm{PE}$ & P-value & $\begin{array}{l}\text { FDR p- } \\
\text { value }\end{array}$ & $\mathrm{PE}$ & P-value & $\begin{array}{l}\text { FDR p- } \\
\text { value }\end{array}$ \\
\hline $\begin{array}{c}\% \\
\text { honey- } \\
\text { suckle } \\
\text { (HS) }\end{array}$ & 0.2857 & 0.1621 & 0.3452 & 0.1298 & 0.6216 & 0.7104 & 0.4746 & 0.0015 & 0.0352 & 0.3948 & 0.0257 & 0.1540 \\
\hline A1 & -0.0815 & 0.6189 & 0.7104 & -0.3290 & 0.1870 & 0.3452 & 0.1048 & 0.3136 & 0.5018 & 0.1918 & 0.1782 & 0.3452 \\
\hline $\mathrm{A} 2$ & $\mathrm{X}$ & $\mathrm{X}$ & $\mathrm{X}$ & $\mathrm{X}$ & $\mathrm{X}$ & $X$ & $\mathrm{X}$ & $\mathrm{X}$ & $\mathrm{X}$ & $X$ & $\mathrm{X}$ & $\mathrm{X}$ \\
\hline A3 & $\mathrm{X}$ & $\mathrm{X}$ & $\mathrm{X}$ & $\mathrm{X}$ & $\mathrm{X}$ & $\mathrm{X}$ & $\mathrm{X}$ & $\mathrm{X}$ & $\mathrm{X}$ & $\mathrm{X}$ & $\mathrm{X}$ & $\mathrm{X}$ \\
\hline HS*A1 & -0.2128 & 0.1599 & 0.3452 & -0.1513 & 0.4629 & 0.6934 & 0.1192 & 0.2241 & 0.3842 & -0.0105 & 0.9336 & 0.9584 \\
\hline HS*A2 & $\mathrm{X}$ & $\mathrm{X}$ & $\mathrm{X}$ & $\mathrm{X}$ & $\mathrm{X}$ & $\mathrm{X}$ & $\mathrm{X}$ & $\mathrm{X}$ & $\mathrm{X}$ & $\mathrm{X}$ & $\mathrm{X}$ & $\mathrm{X}$ \\
\hline HS*A3 & $\mathrm{X}$ & $X$ & $\mathrm{X}$ & $X$ & $X$ & $X$ & $X$ & $X$ & $X$ & $X$ & $X$ & $X$ \\
\hline
\end{tabular}




\section{Appendix 8 continued}

\begin{tabular}{|c|c|c|c|c|c|c|c|c|c|c|c|c|}
\hline \multicolumn{13}{|c|}{ American robin } \\
\hline & \multicolumn{12}{|c|}{ Year 1} \\
\hline & \multicolumn{3}{|c|}{ Winter } & \multicolumn{3}{|c|}{ Spring } & \multicolumn{3}{|c|}{ Summer } & \multicolumn{3}{|c|}{ Fall } \\
\hline & $\mathrm{PE}$ & P-value & $\begin{array}{l}\text { FDR p- } \\
\text { value }\end{array}$ & $\mathrm{PE}$ & P-value & $\begin{array}{c}\text { FDR p- } \\
\text { value }\end{array}$ & $\mathrm{PE}$ & $\mathrm{P}$-value & $\begin{array}{l}\text { FDR p- } \\
\text { value }\end{array}$ & $\mathrm{PE}$ & P-value & $\begin{array}{l}\text { FDR p- } \\
\text { value }\end{array}$ \\
\hline $\begin{array}{c}\% \\
\text { honey- } \\
\text { suckle } \\
\text { (HS) }\end{array}$ & 0.0048 & 0.6366 & 0.7583 & 0.0038 & 0.6894 & 0.7583 & -0.0041 & 0.6331 & 0.7583 & 0.0234 & 0.0154 & 0.0821 \\
\hline A1 & $\mathrm{X}$ & $\mathrm{X}$ & $\mathrm{X}$ & $\mathrm{X}$ & $\mathrm{X}$ & $\mathrm{X}$ & $\mathrm{X}$ & $\mathrm{X}$ & $\mathrm{X}$ & $\mathrm{X}$ & $\mathrm{X}$ & $\mathrm{X}$ \\
\hline $\mathrm{A} 2$ & $\mathrm{X}$ & $\mathrm{X}$ & $\mathrm{X}$ & $\mathrm{X}$ & $\mathrm{X}$ & $\mathrm{X}$ & $\mathrm{X}$ & $\mathrm{X}$ & $\mathrm{X}$ & $\mathrm{X}$ & $\mathrm{X}$ & $\mathrm{X}$ \\
\hline A3 & -0.2671 & 0.4684 & 0.7583 & 0.2147 & 0.5356 & 0.7583 & -1.5543 & 0.0005 & 0.0082 & -0.0105 & 0.9716 & 0.9716 \\
\hline HS*A1 & $\mathrm{X}$ & $\mathrm{X}$ & $\mathrm{X}$ & $\mathrm{X}$ & $\mathrm{X}$ & $\mathrm{X}$ & $\mathrm{X}$ & $\mathrm{X}$ & $\mathrm{X}$ & $\mathrm{X}$ & $\mathrm{X}$ & $\mathrm{X}$ \\
\hline HS*A2 & $\mathrm{X}$ & $\mathrm{X}$ & $\mathrm{X}$ & $\mathrm{X}$ & $\mathrm{X}$ & $\mathrm{X}$ & $\mathrm{X}$ & $\mathrm{X}$ & $\mathrm{X}$ & $\mathrm{X}$ & $\mathrm{X}$ & $\mathrm{X}$ \\
\hline HS*A3 & $X$ & $X$ & $\mathrm{X}$ & $X$ & $X$ & $X$ & $X$ & $X$ & $X$ & $X$ & $\mathrm{X}$ & $X$ \\
\hline
\end{tabular}




\section{Appendix 8 continued}

\begin{tabular}{|c|c|c|c|c|c|c|c|c|c|c|c|c|}
\hline \multicolumn{13}{|c|}{ American robin } \\
\hline & \multicolumn{12}{|c|}{ Year 2} \\
\hline & \multicolumn{3}{|c|}{ Winter } & \multicolumn{3}{|c|}{ Spring } & \multicolumn{3}{|c|}{ Summer } & \multicolumn{3}{|c|}{ Fall } \\
\hline & $\mathrm{PE}$ & P-value & $\begin{array}{l}\text { FDR p- } \\
\text { value }\end{array}$ & $\mathrm{PE}$ & P-value & $\begin{array}{c}\text { FDR p- } \\
\text { value }\end{array}$ & $\mathrm{PE}$ & $\mathrm{P}$-value & $\begin{array}{l}\text { FDR p- } \\
\text { value }\end{array}$ & $\mathrm{PE}$ & P-value & $\begin{array}{l}\text { FDR p- } \\
\text { value }\end{array}$ \\
\hline $\begin{array}{c}\% \\
\text { honey- } \\
\text { suckle } \\
\text { (HS) }\end{array}$ & -0.0222 & 0.2057 & 0.6227 & -0.0151 & 0.2335 & 0.6227 & -0.0107 & 0.4817 & 0.4817 & 0.0437 & 0.0039 & 0.0313 \\
\hline A1 & $\mathrm{X}$ & $\mathrm{X}$ & $\mathrm{X}$ & $\mathrm{X}$ & $\mathrm{X}$ & $\mathrm{X}$ & $\mathrm{X}$ & $\mathrm{X}$ & $\mathrm{X}$ & $\mathrm{X}$ & $\mathrm{X}$ & $\mathrm{X}$ \\
\hline $\mathrm{A} 2$ & $\mathrm{X}$ & $\mathrm{X}$ & $\mathrm{X}$ & $\mathrm{X}$ & $\mathrm{X}$ & $\mathrm{X}$ & $\mathrm{X}$ & $\mathrm{X}$ & $\mathrm{X}$ & $\mathrm{X}$ & $\mathrm{X}$ & $\mathrm{X}$ \\
\hline A3 & -1.1632 & 0.0532 & 0.2129 & -0.2307 & 0.6025 & 0.7583 & -0.2194 & 0.7109 & 0.7583 & -0.2651 & 0.5856 & 0.7583 \\
\hline HS*A1 & $\mathrm{X}$ & $\mathrm{X}$ & $\mathrm{X}$ & $\mathrm{X}$ & $\mathrm{X}$ & $\mathrm{X}$ & $\mathrm{X}$ & $\mathrm{X}$ & $\mathrm{X}$ & $\mathrm{X}$ & $\mathrm{X}$ & $\mathrm{X}$ \\
\hline HS*A2 & $\mathrm{X}$ & $\mathrm{X}$ & $\mathrm{X}$ & $\mathrm{X}$ & $\mathrm{X}$ & $\mathrm{X}$ & $\mathrm{X}$ & $\mathrm{X}$ & $\mathrm{X}$ & $\mathrm{X}$ & $\mathrm{X}$ & $\mathrm{X}$ \\
\hline HS*A3 & $X$ & $X$ & $\mathrm{X}$ & $X$ & $X$ & $X$ & $X$ & $X$ & $X$ & $X$ & $\mathrm{X}$ & $X$ \\
\hline
\end{tabular}




\section{Appendix 8 continued}

\begin{tabular}{|c|c|c|c|c|c|c|c|c|c|c|c|c|}
\hline \multicolumn{13}{|c|}{ Tufted titmouse } \\
\hline & \multicolumn{12}{|c|}{ Year 1} \\
\hline & \multicolumn{3}{|c|}{ Winter } & \multicolumn{3}{|c|}{ Spring } & \multicolumn{3}{|c|}{ Summer } & \multicolumn{3}{|c|}{ Fall } \\
\hline & $\mathrm{PE}$ & P-value & $\begin{array}{l}\text { FDR p- } \\
\text { value }\end{array}$ & $\mathrm{PE}$ & P-value & $\begin{array}{l}\text { FDR p- } \\
\text { value }\end{array}$ & $\mathrm{PE}$ & $\mathrm{P}$-value & $\begin{array}{l}\text { FDR p- } \\
\text { value }\end{array}$ & $\mathrm{PE}$ & P-value & $\begin{array}{l}\text { FDR p- } \\
\text { value }\end{array}$ \\
\hline $\begin{array}{c}\% \\
\text { honey- } \\
\text { suckle } \\
\text { (HS) }\end{array}$ & -0.0139 & 0.5724 & 0.6721 & -0.0015 & 0.8517 & 0.8517 & 0.0048 & 0.5214 & 0.6721 & -0.0162 & 0.0736 & 0.2943 \\
\hline A1 & $\mathrm{X}$ & $\mathrm{X}$ & $\mathrm{X}$ & $\mathrm{X}$ & $\mathrm{X}$ & $\mathrm{X}$ & $\mathrm{X}$ & $\mathrm{X}$ & $\mathrm{X}$ & $\mathrm{X}$ & $\mathrm{X}$ & $\mathrm{X}$ \\
\hline $\mathrm{A} 2$ & $\mathrm{X}$ & $\mathrm{X}$ & $\mathrm{X}$ & $\mathrm{X}$ & $\mathrm{X}$ & $\mathrm{X}$ & $\mathrm{X}$ & $\mathrm{X}$ & $\mathrm{X}$ & $\mathrm{X}$ & $\mathrm{X}$ & $\mathrm{X}$ \\
\hline A3 & $\mathrm{X}$ & $\mathrm{X}$ & $\mathrm{X}$ & $\mathrm{X}$ & $\mathrm{X}$ & $\mathrm{X}$ & $\mathrm{X}$ & $\mathrm{X}$ & $\mathrm{X}$ & $\mathrm{X}$ & $\mathrm{X}$ & $\mathrm{X}$ \\
\hline HS*A1 & $\mathrm{X}$ & $\mathrm{X}$ & $\mathrm{X}$ & $\mathrm{X}$ & $\mathrm{X}$ & $\mathrm{X}$ & $\mathrm{X}$ & $\mathrm{X}$ & $\mathrm{X}$ & $\mathrm{X}$ & $\mathrm{X}$ & $\mathrm{X}$ \\
\hline HS*A2 & $\mathrm{X}$ & $\mathrm{X}$ & $\mathrm{X}$ & $\mathrm{X}$ & $\mathrm{X}$ & $\mathrm{X}$ & $\mathrm{X}$ & $\mathrm{X}$ & $\mathrm{X}$ & $\mathrm{X}$ & $\mathrm{X}$ & $\mathrm{X}$ \\
\hline HS*A3 & $X$ & $X$ & $\mathrm{X}$ & $X$ & $X$ & $X$ & $X$ & $X$ & $X$ & $X$ & $\mathrm{X}$ & $X$ \\
\hline
\end{tabular}




\section{Appendix 8 continued}

\begin{tabular}{|c|c|c|c|c|c|c|c|c|c|c|c|c|}
\hline \multicolumn{13}{|c|}{ Tufted titmouse } \\
\hline & \multicolumn{12}{|c|}{ Year 2} \\
\hline & \multicolumn{3}{|c|}{ Winter } & \multicolumn{3}{|c|}{ Spring } & \multicolumn{3}{|c|}{ Summer } & \multicolumn{3}{|c|}{ Fall } \\
\hline & $\mathrm{PE}$ & P-value & $\begin{array}{l}\text { FDR p- } \\
\text { value }\end{array}$ & $\mathrm{PE}$ & P-value & $\begin{array}{l}\text { FDR p- } \\
\text { value }\end{array}$ & $\mathrm{PE}$ & $\mathrm{P}$-value & $\begin{array}{l}\text { FDR p- } \\
\text { value }\end{array}$ & $\mathrm{PE}$ & P-value & $\begin{array}{l}\text { FDR p- } \\
\text { value }\end{array}$ \\
\hline $\begin{array}{c}\% \\
\text { honey- } \\
\text { suckle } \\
\text { (HS) }\end{array}$ & 0.0129 & 0.0614 & 0.2943 & -0.0062 & 0.4272 & 0.6721 & -0.0077 & 0.5880 & 0.6721 & -0.0088 & 0.4488 & 0.6721 \\
\hline A1 & $\mathrm{X}$ & $\mathrm{X}$ & $\mathrm{X}$ & $\mathrm{X}$ & $\mathrm{X}$ & $\mathrm{X}$ & $\mathrm{X}$ & $\mathrm{X}$ & $\mathrm{X}$ & $\mathrm{X}$ & $\mathrm{X}$ & $\mathrm{X}$ \\
\hline $\mathrm{A} 2$ & $\mathrm{X}$ & $\mathrm{X}$ & $\mathrm{X}$ & $\mathrm{X}$ & $\mathrm{X}$ & $\mathrm{X}$ & $\mathrm{X}$ & $\mathrm{X}$ & $\mathrm{X}$ & $\mathrm{X}$ & $\mathrm{X}$ & $\mathrm{X}$ \\
\hline A3 & $\mathrm{X}$ & $\mathrm{X}$ & $\mathrm{X}$ & $\mathrm{X}$ & $\mathrm{X}$ & $\mathrm{X}$ & $\mathrm{X}$ & $\mathrm{X}$ & $\mathrm{X}$ & $\mathrm{X}$ & $\mathrm{X}$ & $\mathrm{X}$ \\
\hline HS*A1 & $\mathrm{X}$ & $\mathrm{X}$ & $\mathrm{X}$ & $\mathrm{X}$ & $\mathrm{X}$ & $\mathrm{X}$ & $\mathrm{X}$ & $\mathrm{X}$ & $\mathrm{X}$ & $\mathrm{X}$ & $\mathrm{X}$ & $\mathrm{X}$ \\
\hline HS*A2 & $\mathrm{X}$ & $\mathrm{X}$ & $\mathrm{X}$ & $\mathrm{X}$ & $\mathrm{X}$ & $\mathrm{X}$ & $\mathrm{X}$ & $\mathrm{X}$ & $\mathrm{X}$ & $\mathrm{X}$ & $\mathrm{X}$ & $\mathrm{X}$ \\
\hline HS*A3 & $X$ & $X$ & $\mathrm{X}$ & $X$ & $X$ & $X$ & $X$ & $X$ & $X$ & $X$ & $\mathrm{X}$ & $X$ \\
\hline
\end{tabular}




\section{Appendix 8 continued}

\begin{tabular}{|c|c|c|c|c|c|c|c|c|c|c|c|c|}
\hline \multicolumn{13}{|c|}{ Carolina chickadee } \\
\hline & \multicolumn{12}{|c|}{ Year 1} \\
\hline & \multicolumn{3}{|c|}{ Winter } & \multicolumn{3}{|c|}{ Spring } & \multicolumn{3}{|c|}{ Summer } & \multicolumn{3}{|c|}{ Fall } \\
\hline & $\mathrm{PE}$ & P-value & $\begin{array}{l}\text { FDR p- } \\
\text { value }\end{array}$ & $\mathrm{PE}$ & P-value & $\begin{array}{l}\text { FDR p- } \\
\text { value }\end{array}$ & $\mathrm{PE}$ & P-value & $\begin{array}{l}\text { FDR p- } \\
\text { value }\end{array}$ & $\mathrm{PE}$ & P-value & $\begin{array}{l}\text { FDR p- } \\
\text { value }\end{array}$ \\
\hline $\begin{array}{c}\% \\
\text { honey- } \\
\text { suckle } \\
(\mathrm{HS})\end{array}$ & $\mathrm{X}$ & $\mathrm{X}$ & $\mathrm{X}$ & $\mathrm{X}$ & $\mathrm{X}$ & $\mathrm{X}$ & $\mathrm{X}$ & $\mathrm{X}$ & $\mathrm{X}$ & $\mathrm{X}$ & $\mathrm{X}$ & $\mathrm{X}$ \\
\hline A1 & $\mathrm{X}$ & $\mathrm{X}$ & $\mathrm{X}$ & $\mathrm{X}$ & $\mathrm{X}$ & $\mathrm{X}$ & $\mathrm{X}$ & $\mathrm{X}$ & $\mathrm{X}$ & $\mathrm{X}$ & $\mathrm{X}$ & $\mathrm{X}$ \\
\hline $\mathrm{A} 2$ & -0.1322 & 0.5257 & 0.8312 & 0.3450 & 0.0971 & 0.2590 & 0.1653 & 0.3482 & 0.6964 & 0.0724 & 0.6234 & 0.8312 \\
\hline A3 & $\mathrm{X}$ & $\mathrm{X}$ & $\mathrm{X}$ & $\mathrm{X}$ & $\mathrm{X}$ & $\mathrm{X}$ & $\mathrm{X}$ & $\mathrm{X}$ & $\mathrm{X}$ & $\mathrm{X}$ & $\mathrm{X}$ & $\mathrm{X}$ \\
\hline HS*A1 & $\mathrm{X}$ & $\mathrm{X}$ & $\mathrm{X}$ & $\mathrm{X}$ & $\mathrm{X}$ & $\mathrm{X}$ & $\mathrm{X}$ & $\mathrm{X}$ & $\mathrm{X}$ & $\mathrm{X}$ & $\mathrm{X}$ & $\mathrm{X}$ \\
\hline $\mathrm{HS} * \mathrm{~A} 2$ & $\mathrm{X}$ & $\mathrm{X}$ & $\mathrm{X}$ & $\mathrm{X}$ & $\mathrm{X}$ & $\mathrm{X}$ & $\mathrm{X}$ & $\mathrm{X}$ & $\mathrm{X}$ & $\mathrm{X}$ & $\mathrm{X}$ & $\mathrm{X}$ \\
\hline HS*A3 & $X$ & $X$ & $\mathrm{X}$ & $X$ & $X$ & $X$ & $X$ & $X$ & $X$ & $X$ & $\mathrm{X}$ & $X$ \\
\hline
\end{tabular}




\section{Appendix 8 continued}

\begin{tabular}{|c|c|c|c|c|c|c|c|c|c|c|c|c|}
\hline \multicolumn{13}{|c|}{ Carolina chickadee } \\
\hline & \multicolumn{12}{|c|}{ Year 2} \\
\hline & \multicolumn{3}{|c|}{ Winter } & \multicolumn{3}{|c|}{ Spring } & \multicolumn{3}{|c|}{ Summer } & \multicolumn{3}{|c|}{ Fall } \\
\hline & $\mathrm{PE}$ & P-value & $\begin{array}{l}\text { FDR p- } \\
\text { value }\end{array}$ & $\mathrm{PE}$ & P-value & $\begin{array}{l}\text { FDR p- } \\
\text { value }\end{array}$ & $\mathrm{PE}$ & P-value & $\begin{array}{l}\text { FDR p- } \\
\text { value }\end{array}$ & $\mathrm{PE}$ & P-value & $\begin{array}{l}\text { FDR p- } \\
\text { value }\end{array}$ \\
\hline $\begin{array}{c}\% \\
\text { honey- } \\
\text { suckle } \\
(\mathrm{HS})\end{array}$ & $\mathrm{X}$ & $\mathrm{X}$ & $\mathrm{X}$ & $\mathrm{X}$ & $\mathrm{X}$ & $\mathrm{X}$ & $\mathrm{X}$ & $\mathrm{X}$ & $\mathrm{X}$ & $\mathrm{X}$ & $\mathrm{X}$ & $\mathrm{X}$ \\
\hline A1 & $\mathrm{X}$ & $\mathrm{X}$ & $\mathrm{X}$ & $\mathrm{X}$ & $\mathrm{X}$ & $\mathrm{X}$ & $\mathrm{X}$ & $\mathrm{X}$ & $\mathrm{X}$ & $\mathrm{X}$ & $\mathrm{X}$ & $\mathrm{X}$ \\
\hline $\mathrm{A} 2$ & 0.5270 & 0.0387 & 0.1549 & 0.7233 & 0.0167 & 0.1339 & 0.0171 & 0.9584 & 0.9625 & 0.0085 & 0.9625 & 0.9625 \\
\hline A3 & $\mathrm{X}$ & $\mathrm{X}$ & $\mathrm{X}$ & $\mathrm{X}$ & $\mathrm{X}$ & $\mathrm{X}$ & $\mathrm{X}$ & $\mathrm{X}$ & $\mathrm{X}$ & $\mathrm{X}$ & $\mathrm{X}$ & $\mathrm{X}$ \\
\hline HS*A1 & $\mathrm{X}$ & $\mathrm{X}$ & $\mathrm{X}$ & $\mathrm{X}$ & $\mathrm{X}$ & $\mathrm{X}$ & $\mathrm{X}$ & $\mathrm{X}$ & $\mathrm{X}$ & $\mathrm{X}$ & $\mathrm{X}$ & $\mathrm{X}$ \\
\hline $\mathrm{HS} * \mathrm{~A} 2$ & $\mathrm{X}$ & $\mathrm{X}$ & $\mathrm{X}$ & $\mathrm{X}$ & $\mathrm{X}$ & $\mathrm{X}$ & $\mathrm{X}$ & $\mathrm{X}$ & $\mathrm{X}$ & $\mathrm{X}$ & $\mathrm{X}$ & $\mathrm{X}$ \\
\hline HS*A3 & $X$ & $X$ & $\mathrm{X}$ & $X$ & $X$ & $\mathrm{X}$ & $X$ & $X$ & $X$ & $X$ & $\mathrm{X}$ & $X$ \\
\hline
\end{tabular}




\section{Appendix 8 continued}

\begin{tabular}{|c|c|c|c|c|c|c|c|c|c|c|c|c|}
\hline \multicolumn{13}{|c|}{ Carolina wren } \\
\hline & \multicolumn{12}{|c|}{ Year 1} \\
\hline & \multicolumn{3}{|c|}{ Winter } & \multicolumn{3}{|c|}{ Spring } & \multicolumn{3}{|c|}{ Summer } & \multicolumn{3}{|c|}{ Fall } \\
\hline & $\mathrm{PE}$ & $\mathrm{P}$-value & $\begin{array}{l}\text { FDR p- } \\
\text { value }\end{array}$ & $\mathrm{PE}$ & P-value & $\begin{array}{l}\text { FDR p- } \\
\text { value }\end{array}$ & $\mathrm{PE}$ & P-value & $\begin{array}{l}\text { FDR p- } \\
\text { value }\end{array}$ & $\mathrm{PE}$ & P-value & $\begin{array}{l}\text { FDR p- } \\
\text { value }\end{array}$ \\
\hline $\begin{array}{c}\% \\
\text { honey- } \\
\text { suckle } \\
(\mathrm{HS})\end{array}$ & -0.1366 & 0.9174 & 0.9809 & 0.0090 & 0.8684 & 0.9809 & 0.0516 & 0.1488 & 0.4900 & 0.1598 & 0.0068 & 0.1353 \\
\hline A1 & $\mathrm{X}$ & $X$ & $X$ & $\mathrm{X}$ & $\mathrm{X}$ & $\mathrm{X}$ & $\mathrm{X}$ & $\mathrm{X}$ & $\mathrm{X}$ & $\mathrm{X}$ & $\mathrm{X}$ & $\mathrm{X}$ \\
\hline A2 & 1.3776 & 0.4863 & 0.7481 & -1.4102 & 0.1765 & 0.4900 & -0.1196 & 0.8654 & 0.9809 & -3.2489 & 0.0017 & 0.0699 \\
\hline A3 & 0.2528 & 0.8782 & 0.9809 & -0.4305 & 0.6439 & 0.9171 & -0.0754 & 0.8793 & 0.9809 & -0.6607 & 0.1270 & 0.4900 \\
\hline HS*A1 & $\bar{X}$ & $X$ & $X$ & $\mathrm{X}$ & $\bar{X}$ & $\mathrm{X}$ & $\mathrm{X}$ & $\mathrm{X}$ & $\mathrm{X}$ & $\mathrm{X}$ & $\mathrm{X}$ & $\mathrm{X}$ \\
\hline HS*A2 & -0.3556 & 0.8182 & 0.9809 & 0.0810 & 0.3442 & 0.5987 & -0.0298 & 0.1143 & 0.4900 & -0.0455 & 0.0522 & 0.4900 \\
\hline HS*A3 & 3.0839 & 0.6649 & 0.9171 & 0.0791 & 0.3420 & 0.5987 & 0.0023 & 0.9422 & 0.9809 & 0.1577 & 0.0259 & 0.3455 \\
\hline
\end{tabular}




\section{Appendix 8 continued}

\begin{tabular}{|c|c|c|c|c|c|c|c|c|c|c|c|c|}
\hline \multicolumn{13}{|c|}{ Carolina wren } \\
\hline & \multicolumn{12}{|c|}{ Year 2} \\
\hline & \multicolumn{3}{|c|}{ Winter } & \multicolumn{3}{|c|}{ Spring } & \multicolumn{3}{|c|}{ Summer } & \multicolumn{3}{|c|}{ Fall } \\
\hline & $\mathrm{PE}$ & P-value & $\begin{array}{l}\text { FDR p- } \\
\text { value }\end{array}$ & $\mathrm{PE}$ & P-value & $\begin{array}{c}\text { FDR p- } \\
\text { value }\end{array}$ & $\mathrm{PE}$ & $\mathrm{P}$-value & $\begin{array}{l}\text { FDR p- } \\
\text { value }\end{array}$ & $\mathrm{PE}$ & P-value & $\begin{array}{l}\text { FDR p- } \\
\text { value }\end{array}$ \\
\hline $\begin{array}{c}\% \\
\text { honey- } \\
\text { suckle } \\
\text { (HS) }\end{array}$ & -0.1604 & 0.0711 & 0.4900 & 0.0442 & 0.2345 & 0.5547 & -0.0452 & 0.2358 & 0.5547 & -0.0049 & 0.9163 & 0.9809 \\
\hline A1 & $\mathrm{X}$ & $\mathrm{X}$ & $\mathrm{X}$ & $\mathrm{X}$ & $\mathrm{X}$ & $\mathrm{X}$ & $\mathrm{X}$ & $\mathrm{X}$ & $\mathrm{X}$ & $\mathrm{X}$ & $\mathrm{X}$ & $\mathrm{X}$ \\
\hline $\mathrm{A} 2$ & 2.1002 & 0.1791 & 0.4900 & -0.2440 & 0.7716 & 0.9809 & 0.8098 & 0.1837 & 0.4900 & -1.2669 & 0.1137 & 0.4900 \\
\hline A3 & 1.0817 & 0.4382 & 0.7211 & -0.3030 & 0.5793 & 0.8582 & 0.4268 & 0.4507 & 0.7211 & -0.5946 & 0.2829 & 0.5658 \\
\hline HS*A1 & $\mathrm{X}$ & $\mathrm{X}$ & $\mathrm{X}$ & $\mathrm{X}$ & $\mathrm{X}$ & $\mathrm{X}$ & $\mathrm{X}$ & $\mathrm{X}$ & $\mathrm{X}$ & $\mathrm{X}$ & $\mathrm{X}$ & $X$ \\
\hline HS*A2 & 0.0588 & 0.2781 & 0.5658 & -0.0382 & 0.0912 & 0.4900 & 0.0005 & 0.9809 & 0.9809 & 0.0360 & 0.1456 & 0.4900 \\
\hline HS*A3 & -0.1464 & 0.2808 & 0.5658 & 0.0015 & 0.9674 & 0.9809 & -0.0597 & 0.1535 & 0.4900 & 0.0581 & 0.3248 & 0.5987 \\
\hline
\end{tabular}




\section{Appendix 8 continued}

\begin{tabular}{|c|c|c|c|c|c|c|c|c|c|c|c|c|}
\hline \multicolumn{13}{|c|}{ Blue jay } \\
\hline & \multicolumn{12}{|c|}{ Year 1} \\
\hline & \multicolumn{3}{|c|}{ Winter } & \multicolumn{3}{|c|}{ Spring } & \multicolumn{3}{|c|}{ Summer } & \multicolumn{3}{|c|}{ Fall } \\
\hline & $\mathrm{PE}$ & P-value & $\begin{array}{l}\text { FDR p- } \\
\text { value }\end{array}$ & $\mathrm{PE}$ & P-value & $\begin{array}{l}\text { FDR p- } \\
\text { value }\end{array}$ & $\mathrm{PE}$ & $\mathrm{P}$-value & $\begin{array}{c}\text { FDR p- } \\
\text { value }\end{array}$ & $\mathrm{PE}$ & P-value & $\begin{array}{c}\text { FDR p- } \\
\text { value }\end{array}$ \\
\hline $\begin{array}{c}\% \\
\text { honey- } \\
\text { suckle } \\
\text { (HS) }\end{array}$ & 0.0331 & 0.5009 & 0.5343 & 0.0653 & 0.0683 & 0.2534 & -0.0983 & 0.0058 & 0.0460 & -0.0697 & 0.3149 & 0.4976 \\
\hline A1 & $\mathrm{X}$ & $\mathrm{X}$ & $\mathrm{X}$ & $\mathrm{X}$ & $\mathrm{X}$ & $\mathrm{X}$ & $\mathrm{X}$ & $X$ & $\mathrm{X}$ & $\mathrm{X}$ & $X$ & $X$ \\
\hline $\mathrm{A} 2$ & -0.8513 & 0.4354 & 0.4976 & -1.1948 & 0.1452 & 0.3547 & 2.2613 & 0.0052 & 0.0460 & 1.0614 & 0.3655 & 0.4976 \\
\hline A3 & $\mathrm{X}$ & $\mathrm{X}$ & $\mathrm{X}$ & $\mathrm{X}$ & $\mathrm{X}$ & $\mathrm{X}$ & $\mathrm{X}$ & $\mathrm{X}$ & $\mathrm{X}$ & $\mathrm{X}$ & $\mathrm{X}$ & $\mathrm{X}$ \\
\hline HS*A1 & $\mathrm{X}$ & $\mathrm{X}$ & $\mathrm{X}$ & $\mathrm{X}$ & $\mathrm{X}$ & $\mathrm{X}$ & $\mathrm{X}$ & $\mathrm{X}$ & $\mathrm{X}$ & $\mathrm{X}$ & $\mathrm{X}$ & $\mathrm{X}$ \\
\hline HS*A2 & $\mathrm{X}$ & $\mathrm{X}$ & $\mathrm{X}$ & $\mathrm{X}$ & $\mathrm{X}$ & $\mathrm{X}$ & $\mathrm{X}$ & $\mathrm{X}$ & $\mathrm{X}$ & $\mathrm{X}$ & $\mathrm{X}$ & $\mathrm{X}$ \\
\hline HS*A3 & $X$ & $X$ & $X$ & $X$ & $X$ & $X$ & $X$ & $X$ & $X$ & $X$ & $X$ & $X$ \\
\hline
\end{tabular}




\section{Appendix 8 continued}

\begin{tabular}{|c|c|c|c|c|c|c|c|c|c|c|c|c|}
\hline \multicolumn{13}{|c|}{ Blue jay } \\
\hline & \multicolumn{12}{|c|}{ Year 2} \\
\hline & \multicolumn{3}{|c|}{ Winter } & \multicolumn{3}{|c|}{ Spring } & \multicolumn{3}{|c|}{ Summer } & \multicolumn{3}{|c|}{ Fall } \\
\hline & $\mathrm{PE}$ & P-value & $\begin{array}{l}\text { FDR p- } \\
\text { value }\end{array}$ & $\mathrm{PE}$ & P-value & $\begin{array}{l}\text { FDR p- } \\
\text { value }\end{array}$ & $\mathrm{PE}$ & $\mathrm{P}$-value & $\begin{array}{l}\text { FDR p- } \\
\text { value }\end{array}$ & $\mathrm{PE}$ & P-value & $\begin{array}{l}\text { FDR p- } \\
\text { value }\end{array}$ \\
\hline $\begin{array}{c}\% \\
\text { honey- } \\
\text { suckle } \\
\text { (HS) }\end{array}$ & 0.0931 & 0.0645 & 0.2534 & 0.0166 & 0.4150 & 0.4976 & -0.0014 & 0.9770 & 0.9770 & -0.0164 & 0.3895 & 0.4976 \\
\hline A1 & $\mathrm{X}$ & $\mathrm{X}$ & $\mathrm{X}$ & $\mathrm{X}$ & $\mathrm{X}$ & $\mathrm{X}$ & $\mathrm{X}$ & $\mathrm{X}$ & $\mathrm{X}$ & $\mathrm{X}$ & $\mathrm{X}$ & $\mathrm{X}$ \\
\hline $\mathrm{A} 2$ & -2.6291 & 0.0792 & 0.2534 & -0.6399 & 0.2737 & 0.4976 & -1.9271 & 0.3898 & 0.4976 & 0.7628 & 0.1552 & 0.3547 \\
\hline A3 & $\mathrm{X}$ & $\mathrm{X}$ & $\mathrm{X}$ & $\mathrm{X}$ & $\mathrm{X}$ & $\mathrm{X}$ & $\mathrm{X}$ & $\mathrm{X}$ & $\mathrm{X}$ & $\mathrm{X}$ & $\mathrm{X}$ & $\mathrm{X}$ \\
\hline HS*A1 & $\mathrm{X}$ & $\mathrm{X}$ & $\mathrm{X}$ & $\mathrm{X}$ & $\mathrm{X}$ & $\mathrm{X}$ & $\mathrm{X}$ & $\mathrm{X}$ & $\mathrm{X}$ & $\mathrm{X}$ & $\mathrm{X}$ & $\mathrm{X}$ \\
\hline HS*A2 & $\mathrm{X}$ & $\mathrm{X}$ & $\mathrm{X}$ & $\mathrm{X}$ & $\mathrm{X}$ & $\mathrm{X}$ & $\mathrm{X}$ & $\mathrm{X}$ & $\mathrm{X}$ & $\mathrm{X}$ & $\mathrm{X}$ & $\mathrm{X}$ \\
\hline HS*A3 & $X$ & $X$ & $\mathrm{X}$ & $X$ & $X$ & $X$ & $X$ & $X$ & $X$ & $X$ & $\mathrm{X}$ & $X$ \\
\hline
\end{tabular}




\section{Appendix 8 continued}

\begin{tabular}{|c|c|c|c|c|c|c|c|c|c|c|c|c|}
\hline \multicolumn{13}{|c|}{ White-breasted nuthatch } \\
\hline & \multicolumn{12}{|c|}{ Year 1} \\
\hline & \multicolumn{3}{|c|}{ Winter } & \multicolumn{3}{|c|}{ Spring } & \multicolumn{3}{|c|}{ Summer } & \multicolumn{3}{|c|}{ Fall } \\
\hline & $\mathrm{PE}$ & P-value & $\begin{array}{c}\text { FDR p- } \\
\text { value }\end{array}$ & $\mathrm{PE}$ & P-value & $\begin{array}{l}\text { FDR p- } \\
\text { value }\end{array}$ & $\mathrm{PE}$ & $\mathrm{P}$-value & $\begin{array}{l}\text { FDR p- } \\
\text { value }\end{array}$ & $\mathrm{PE}$ & P-value & $\begin{array}{l}\text { FDR p- } \\
\text { value }\end{array}$ \\
\hline $\begin{array}{c}\% \\
\text { honey- } \\
\text { suckle } \\
\text { (HS) }\end{array}$ & -0.0099 & 0.7655 & 0.7655 & -0.0153 & 0.5507 & 0.7655 & -0.0350 & 0.1211 & 0.7655 & -0.0076 & 0.6193 & 0.7655 \\
\hline A1 & $\mathrm{X}$ & $\mathrm{X}$ & $\mathrm{X}$ & $\mathrm{X}$ & $\mathrm{X}$ & $\mathrm{X}$ & $\mathrm{X}$ & $\mathrm{X}$ & $\mathrm{X}$ & $\mathrm{X}$ & $\mathrm{X}$ & $\mathrm{X}$ \\
\hline $\mathrm{A} 2$ & $\mathrm{X}$ & $\mathrm{X}$ & $\mathrm{X}$ & $\mathrm{X}$ & $\mathrm{X}$ & $\mathrm{X}$ & $\mathrm{X}$ & $\mathrm{X}$ & $\mathrm{X}$ & $\mathrm{X}$ & $\mathrm{X}$ & $\mathrm{X}$ \\
\hline A3 & $\mathrm{X}$ & $\mathrm{X}$ & $\mathrm{X}$ & $\mathrm{X}$ & $\mathrm{X}$ & $\mathrm{X}$ & $\mathrm{X}$ & $\mathrm{X}$ & $\mathrm{X}$ & $\mathrm{X}$ & $\mathrm{X}$ & $\mathrm{X}$ \\
\hline HS*A1 & $\mathrm{X}$ & $\mathrm{X}$ & $\mathrm{X}$ & $\mathrm{X}$ & $\mathrm{X}$ & $\mathrm{X}$ & $\mathrm{X}$ & $\mathrm{X}$ & $\mathrm{X}$ & $\mathrm{X}$ & $\mathrm{X}$ & $\mathrm{X}$ \\
\hline HS*A2 & $\mathrm{X}$ & $\mathrm{X}$ & $X$ & $X$ & $X$ & $X$ & $X$ & $X$ & $X$ & $\mathrm{X}$ & $X$ & $X$ \\
\hline HS*A3 & $X$ & $X$ & $X$ & $X$ & $X$ & $X$ & $X$ & $X$ & $X$ & $X$ & $X$ & $X$ \\
\hline
\end{tabular}




\section{Appendix 8 continued}

\begin{tabular}{|c|c|c|c|c|c|c|c|c|c|c|c|c|}
\hline \multicolumn{13}{|c|}{ White-breasted nuthatch } \\
\hline & \multicolumn{12}{|c|}{ Year 2} \\
\hline & \multicolumn{3}{|c|}{ Winter } & \multicolumn{3}{|c|}{ Spring } & \multicolumn{3}{|c|}{ Summer } & \multicolumn{3}{|c|}{ Fall } \\
\hline & $\mathrm{PE}$ & $\mathrm{P}$-value & $\begin{array}{c}\text { FDR p- } \\
\text { value }\end{array}$ & $\mathrm{PE}$ & P-value & $\begin{array}{l}\text { FDR p- } \\
\text { value }\end{array}$ & $\mathrm{PE}$ & $\mathrm{P}$-value & $\begin{array}{l}\text { FDR p- } \\
\text { value }\end{array}$ & $\mathrm{PE}$ & P-value & $\begin{array}{l}\text { FDR p- } \\
\text { value }\end{array}$ \\
\hline $\begin{array}{c}\% \\
\text { honey- } \\
\text { suckle } \\
\text { (HS) }\end{array}$ & -0.0052 & 0.7309 & 0.7655 & 0.0161 & 0.4391 & 0.7655 & -0.0394 & 0.6199 & 0.7655 & -0.0098 & 0.5163 & 0.7655 \\
\hline A1 & $\mathrm{X}$ & $\mathrm{X}$ & $\mathrm{X}$ & $\mathrm{X}$ & $\mathrm{X}$ & $\mathrm{X}$ & $\mathrm{X}$ & $\mathrm{X}$ & $\mathrm{X}$ & $\mathrm{X}$ & $\mathrm{X}$ & $\mathrm{X}$ \\
\hline $\mathrm{A} 2$ & $\mathrm{X}$ & $\mathrm{X}$ & $\mathrm{X}$ & $\mathrm{X}$ & $\mathrm{X}$ & $X$ & $\mathrm{X}$ & $\mathrm{X}$ & $\mathrm{X}$ & $\mathrm{X}$ & $\mathrm{X}$ & $\mathrm{X}$ \\
\hline A3 & $\mathrm{X}$ & $\mathrm{X}$ & $\mathrm{X}$ & $\mathrm{X}$ & $\mathrm{X}$ & $\mathrm{X}$ & $\mathrm{X}$ & $\mathrm{X}$ & $\mathrm{X}$ & $\mathrm{X}$ & $\mathrm{X}$ & $\mathrm{X}$ \\
\hline HS*A1 & $\mathrm{X}$ & $\mathrm{X}$ & $\mathrm{X}$ & $\mathrm{X}$ & $\mathrm{X}$ & $\mathrm{X}$ & $\mathrm{X}$ & $\mathrm{X}$ & $\mathrm{X}$ & $\mathrm{X}$ & $\mathrm{X}$ & $\mathrm{X}$ \\
\hline HS*A2 & $\mathrm{X}$ & $X$ & $X$ & $X$ & $X$ & $X$ & $X$ & $X$ & $\mathrm{X}$ & $X$ & $X$ & $\mathrm{X}$ \\
\hline HS*A3 & $X$ & $X$ & $X$ & $X$ & $X$ & $X$ & $X$ & $X$ & $X$ & $X$ & $X$ & $X$ \\
\hline
\end{tabular}




\section{Appendix 8 continued}

\begin{tabular}{|c|c|c|c|c|c|c|c|c|c|c|c|c|}
\hline \multicolumn{13}{|c|}{ Thrushes (Family Turdidae) } \\
\hline & \multicolumn{12}{|c|}{ 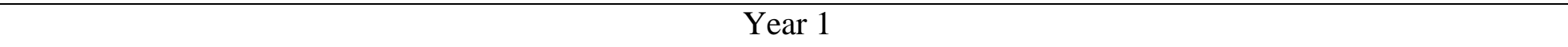 } \\
\hline & \multicolumn{3}{|c|}{ Winter } & \multicolumn{3}{|c|}{ Spring } & \multicolumn{3}{|c|}{ Summer } & \multicolumn{3}{|c|}{ Fall } \\
\hline & $\mathrm{PE}$ & P-value & $\begin{array}{l}\text { FDR p- } \\
\text { value }\end{array}$ & $\mathrm{PE}$ & P-value & $\begin{array}{l}\text { FDR p- } \\
\text { value }\end{array}$ & $\mathrm{PE}$ & $\mathrm{P}$-value & $\begin{array}{l}\text { FDR p- } \\
\text { value }\end{array}$ & $\mathrm{PE}$ & P-value & $\begin{array}{l}\text { FDR p- } \\
\text { value }\end{array}$ \\
\hline $\begin{array}{c}\% \\
\text { honey- } \\
\text { suckle } \\
\text { (HS) }\end{array}$ & 0.0038 & 0.7191 & 0.9696 & -0.0003 & 0.9696 & 0.9696 & 0.0018 & 0.8957 & 0.9696 & 0.0249 & 0.0034 & 0.0136 \\
\hline A1 & $\mathrm{X}$ & $\mathrm{X}$ & $\mathrm{X}$ & $\mathrm{X}$ & $\mathrm{X}$ & $\mathrm{X}$ & $\mathrm{X}$ & $\mathrm{X}$ & $\mathrm{X}$ & $\mathrm{X}$ & $\mathrm{X}$ & $\mathrm{X}$ \\
\hline $\mathrm{A} 2$ & $\mathrm{X}$ & $\mathrm{X}$ & $\mathrm{X}$ & $\mathrm{X}$ & $\mathrm{X}$ & $\mathrm{X}$ & $X$ & $\mathrm{X}$ & $\mathrm{X}$ & $X$ & $\mathrm{X}$ & $\mathrm{X}$ \\
\hline A3 & $\mathrm{X}$ & $\mathrm{X}$ & $\mathrm{X}$ & $\mathrm{X}$ & $\mathrm{X}$ & $\mathrm{X}$ & $\mathrm{X}$ & $\mathrm{X}$ & $\mathrm{X}$ & $\mathrm{X}$ & $\mathrm{X}$ & $\mathrm{X}$ \\
\hline HS*A1 & $\mathrm{X}$ & $\mathrm{X}$ & $\mathrm{X}$ & $X$ & $X$ & X & $X$ & $X$ & $\mathrm{X}$ & $X$ & $\mathrm{X}$ & $X$ \\
\hline HS*A2 & $X$ & $X$ & $X$ & $X$ & $X$ & $\mathrm{X}$ & $X$ & $X$ & $\mathrm{X}$ & $X$ & $\mathrm{X}$ & $X$ \\
\hline HS*A3 & $X$ & $X$ & $X$ & $X$ & $X$ & $X$ & $X$ & $X$ & $X$ & $X$ & $X$ & $X$ \\
\hline
\end{tabular}




\section{Appendix 8 continued}

\begin{tabular}{|c|c|c|c|c|c|c|c|c|c|c|c|c|}
\hline \multicolumn{13}{|c|}{ Thrushes (Family Turdidae) } \\
\hline & \multicolumn{12}{|c|}{ Year 2} \\
\hline & \multicolumn{3}{|c|}{ Winter } & \multicolumn{3}{|c|}{ Spring } & \multicolumn{3}{|c|}{ Summer } & \multicolumn{3}{|c|}{ Fall } \\
\hline & $\mathrm{PE}$ & P-value & $\begin{array}{l}\text { FDR p- } \\
\text { value }\end{array}$ & $\mathrm{PE}$ & P-value & $\begin{array}{l}\text { FDR p- } \\
\text { value }\end{array}$ & $\mathrm{PE}$ & P-value & $\begin{array}{c}\text { FDR p- } \\
\text { value }\end{array}$ & $\mathrm{PE}$ & P-value & $\begin{array}{c}\text { FDR p- } \\
\text { value }\end{array}$ \\
\hline $\begin{array}{c}\% \\
\text { honey- } \\
\text { suckle } \\
\text { (HS) }\end{array}$ & -0.0062 & 0.7588 & 0.9696 & -0.0044 & 0.6378 & 0.9696 & -0.0109 & 0.4180 & 0.9696 & 0.0448 & 0.0028 & 0.0136 \\
\hline A1 & $\mathrm{X}$ & $\mathrm{X}$ & $\mathrm{X}$ & $\mathrm{X}$ & $\mathrm{X}$ & $\mathrm{X}$ & $\mathrm{X}$ & $\mathrm{X}$ & $\mathrm{X}$ & $\mathrm{X}$ & $\mathrm{X}$ & $\mathrm{X}$ \\
\hline $\mathrm{A} 2$ & $\mathrm{X}$ & $\mathrm{X}$ & $\mathrm{X}$ & $\mathrm{X}$ & $\mathrm{X}$ & $\mathrm{X}$ & $X$ & $\mathrm{X}$ & $\mathrm{X}$ & $X$ & $\mathrm{X}$ & $\mathrm{X}$ \\
\hline A3 & $\mathrm{X}$ & $\mathrm{X}$ & $\mathrm{X}$ & $\mathrm{X}$ & $\mathrm{X}$ & $\mathrm{X}$ & $\mathrm{X}$ & $\mathrm{X}$ & $\mathrm{X}$ & $\mathrm{X}$ & $\mathrm{X}$ & $\mathrm{X}$ \\
\hline HS*A1 & $\mathrm{X}$ & $\mathrm{X}$ & $\mathrm{X}$ & $X$ & $X$ & X & $X$ & $X$ & $\mathrm{X}$ & $X$ & $\mathrm{X}$ & $X$ \\
\hline HS*A2 & $X$ & $X$ & $X$ & $X$ & $X$ & $\mathrm{X}$ & $X$ & $X$ & $\mathrm{X}$ & $X$ & $\mathrm{X}$ & $X$ \\
\hline HS*A3 & $X$ & $X$ & $X$ & $X$ & $X$ & $X$ & $X$ & $X$ & $X$ & $X$ & $X$ & $X$ \\
\hline
\end{tabular}




\section{Appendix 8 continued}

\begin{tabular}{|c|c|c|c|c|c|c|c|c|c|c|c|c|}
\hline \multicolumn{13}{|c|}{ Parids (Family Paridae) } \\
\hline & \multicolumn{12}{|c|}{ Year 1} \\
\hline & \multicolumn{3}{|c|}{ Winter } & \multicolumn{3}{|c|}{ Spring } & \multicolumn{3}{|c|}{ Summer } & \multicolumn{3}{|c|}{ Fall } \\
\hline & $\mathrm{PE}$ & $\mathrm{P}$-value & $\begin{array}{c}\text { FDR p- } \\
\text { value }\end{array}$ & $\mathrm{PE}$ & P-value & $\begin{array}{l}\text { FDR p- } \\
\text { value }\end{array}$ & $\mathrm{PE}$ & $\mathrm{P}$-value & $\begin{array}{l}\text { FDR p- } \\
\text { value }\end{array}$ & $\mathrm{PE}$ & P-value & $\begin{array}{l}\text { FDR p- } \\
\text { value }\end{array}$ \\
\hline $\begin{array}{c}\% \\
\text { honey- } \\
\text { suckle } \\
\text { (HS) }\end{array}$ & -0.1847 & 0.1629 & 0.4791 & 0.1495 & 0.1221 & 0.4791 & 0.1817 & 0.0788 & 0.4791 & 0.0461 & 0.5841 & 0.7189 \\
\hline A1 & -0.0140 & 0.8992 & 0.8992 & -0.1210 & 0.2361 & 0.4791 & 0.1421 & 0.1849 & 0.4791 & 0.1149 & 0.1873 & 0.4791 \\
\hline $\mathrm{A} 2$ & $\mathrm{X}$ & $\mathrm{X}$ & $\mathrm{X}$ & $\mathrm{X}$ & $\mathrm{X}$ & $\mathrm{X}$ & $\mathrm{X}$ & $\mathrm{X}$ & $\mathrm{X}$ & $\mathrm{X}$ & $\mathrm{X}$ & $\mathrm{X}$ \\
\hline A3 & $\mathrm{X}$ & $\mathrm{X}$ & $\mathrm{X}$ & $\mathrm{X}$ & $\mathrm{X}$ & $\mathrm{X}$ & $\mathrm{X}$ & $\mathrm{X}$ & $\mathrm{X}$ & $\mathrm{X}$ & $\mathrm{X}$ & $\mathrm{X}$ \\
\hline HS*A1 & $\mathrm{X}$ & $\mathrm{X}$ & $\mathrm{X}$ & $\mathrm{X}$ & $\mathrm{X}$ & $\mathrm{X}$ & $\mathrm{X}$ & $\mathrm{X}$ & $\mathrm{X}$ & $\mathrm{X}$ & $\mathrm{X}$ & $\mathrm{X}$ \\
\hline HS*A2 & $\mathrm{X}$ & $\mathrm{X}$ & $X$ & $X$ & $\mathrm{X}$ & $X$ & $X$ & $X$ & $X$ & $\mathrm{X}$ & $X$ & $X$ \\
\hline HS*A3 & $X$ & $X$ & $X$ & $X$ & $X$ & $X$ & $X$ & $X$ & $X$ & $X$ & $X$ & $X$ \\
\hline
\end{tabular}




\section{Appendix 8 continued}

\begin{tabular}{|c|c|c|c|c|c|c|c|c|c|c|c|c|}
\hline \multicolumn{13}{|c|}{ Parids (Family Paridae) } \\
\hline & \multicolumn{12}{|c|}{ Year 2} \\
\hline & \multicolumn{3}{|c|}{ Winter } & \multicolumn{3}{|c|}{ Spring } & \multicolumn{3}{|c|}{ Summer } & \multicolumn{3}{|c|}{ Fall } \\
\hline & $\mathrm{PE}$ & P-value & $\begin{array}{c}\text { FDR p- } \\
\text { value }\end{array}$ & $\mathrm{PE}$ & P-value & $\begin{array}{l}\text { FDR p- } \\
\text { value }\end{array}$ & $\mathrm{PE}$ & $\mathrm{P}$-value & $\begin{array}{l}\text { FDR p- } \\
\text { value }\end{array}$ & $\mathrm{PE}$ & P-value & $\begin{array}{l}\text { FDR p- } \\
\text { value }\end{array}$ \\
\hline $\begin{array}{c}\% \\
\text { honey- } \\
\text { suckle } \\
\text { (HS) }\end{array}$ & 0.2837 & 0.0142 & 0.2266 & 0.0754 & 0.4858 & 0.6564 & -0.2336 & 0.2533 & 0.4791 & -0.0724 & 0.4923 & 0.6564 \\
\hline A1 & 0.1071 & 0.3503 & 0.5604 & -0.1259 & 0.2695 & 0.4791 & -0.0796 & 0.7161 & 0.8184 & 0.0281 & 0.7748 & 0.8265 \\
\hline $\mathrm{A} 2$ & $\mathrm{X}$ & $\mathrm{X}$ & $\mathrm{X}$ & $\mathrm{X}$ & $\mathrm{X}$ & $\mathrm{X}$ & $\mathrm{X}$ & $\mathrm{X}$ & $\mathrm{X}$ & $\mathrm{X}$ & $\mathrm{X}$ & $\mathrm{X}$ \\
\hline A3 & $\mathrm{X}$ & $\mathrm{X}$ & $\mathrm{X}$ & $\mathrm{X}$ & $\mathrm{X}$ & $\mathrm{X}$ & $\mathrm{X}$ & $\mathrm{X}$ & $\mathrm{X}$ & $\mathrm{X}$ & $\mathrm{X}$ & $\mathrm{X}$ \\
\hline HS*A1 & $\mathrm{X}$ & $\mathrm{X}$ & $\mathrm{X}$ & $\mathrm{X}$ & $\mathrm{X}$ & $\mathrm{X}$ & $\mathrm{X}$ & $\mathrm{X}$ & $\mathrm{X}$ & $\mathrm{X}$ & $\mathrm{X}$ & $\mathrm{X}$ \\
\hline HS*A2 & $\mathrm{X}$ & $\mathrm{X}$ & $X$ & $X$ & $\mathrm{X}$ & $X$ & $X$ & $X$ & $X$ & $X$ & $X$ & $X$ \\
\hline HS*A3 & $X$ & $X$ & $X$ & $X$ & $X$ & $X$ & $X$ & $X$ & $X$ & $X$ & $X$ & $X$ \\
\hline
\end{tabular}




\section{Appendix 8 continued}

\begin{tabular}{|c|c|c|c|c|c|c|c|c|c|c|c|c|}
\hline \multicolumn{13}{|c|}{ Woodpeckers (Family Picidae) } \\
\hline & \multicolumn{12}{|c|}{ Year 1} \\
\hline & \multicolumn{3}{|c|}{ Winter } & \multicolumn{3}{|c|}{ Spring } & \multicolumn{3}{|c|}{ Summer } & \multicolumn{3}{|c|}{ Fall } \\
\hline & $\mathrm{PE}$ & P-value & $\begin{array}{l}\text { FDR p- } \\
\text { value }\end{array}$ & $\mathrm{PE}$ & P-value & $\begin{array}{l}\text { FDR p- } \\
\text { value }\end{array}$ & $\mathrm{PE}$ & P-value & $\begin{array}{l}\text { FDR p- } \\
\text { value }\end{array}$ & $\mathrm{PE}$ & P-value & $\begin{array}{l}\text { FDR p- } \\
\text { value }\end{array}$ \\
\hline $\begin{array}{c}\% \\
\text { honey- } \\
\text { suckle } \\
\text { (HS) }\end{array}$ & 0.0094 & 0.9814 & 0.9814 & 0.3286 & 0.3369 & 0.5391 & 0.0605 & 0.8736 & 0.9814 & -0.1861 & 0.4505 & 0.6552 \\
\hline A1 & $\mathrm{X}$ & $\mathrm{X}$ & $\mathrm{X}$ & $\mathrm{X}$ & $\mathrm{X}$ & $\mathrm{X}$ & $\mathrm{X}$ & $\mathrm{X}$ & $\mathrm{X}$ & $\mathrm{X}$ & $\mathrm{X}$ & $\mathrm{X}$ \\
\hline $\mathrm{A} 2$ & -0.1797 & 0.6777 & 0.9036 & -0.6724 & 0.0548 & 0.2460 & -0.3876 & 0.2891 & 0.5391 & 0.0091 & 0.9694 & 0.9814 \\
\hline A3 & $\mathrm{X}$ & $\mathrm{X}$ & $\mathrm{X}$ & $\mathrm{X}$ & $\mathrm{X}$ & $\mathrm{X}$ & $\mathrm{X}$ & $\mathrm{X}$ & $\mathrm{X}$ & $\mathrm{X}$ & $\mathrm{X}$ & $\mathrm{X}$ \\
\hline HS*A1 & $X$ & $X$ & $\mathrm{X}$ & $X$ & $\mathrm{X}$ & $X$ & $X$ & $X$ & $\mathrm{X}$ & $\mathrm{X}$ & $\mathrm{X}$ & $\mathrm{X}$ \\
\hline HS*A2 & $X$ & $X$ & $\mathrm{X}$ & $\mathrm{X}$ & $\mathrm{X}$ & $X$ & $X$ & $\mathrm{X}$ & $X$ & $\mathrm{X}$ & $\mathrm{X}$ & $\mathrm{X}$ \\
\hline HS*A3 & $X$ & $X$ & $X$ & $X$ & $X$ & $X$ & $X$ & $X$ & $X$ & $X$ & $X$ & $X$ \\
\hline
\end{tabular}




\section{Appendix 8 continued}

\begin{tabular}{|c|c|c|c|c|c|c|c|c|c|c|c|c|}
\hline \multicolumn{13}{|c|}{ Woodpeckers (Family Picidae) } \\
\hline & \multicolumn{12}{|c|}{ Year 2} \\
\hline & \multicolumn{3}{|c|}{ Winter } & \multicolumn{3}{|c|}{ Spring } & \multicolumn{3}{|c|}{ Summer } & \multicolumn{3}{|c|}{ Fall } \\
\hline & $\mathrm{PE}$ & P-value & $\begin{array}{l}\text { FDR p- } \\
\text { value }\end{array}$ & $\mathrm{PE}$ & P-value & $\begin{array}{l}\text { FDR p- } \\
\text { value }\end{array}$ & $\mathrm{PE}$ & P-value & $\begin{array}{l}\text { FDR p- } \\
\text { value }\end{array}$ & $\mathrm{PE}$ & P-value & $\begin{array}{l}\text { FDR p- } \\
\text { value }\end{array}$ \\
\hline $\begin{array}{c}\% \\
\text { honey- } \\
\text { suckle } \\
\text { (HS) }\end{array}$ & 0.7910 & 0.0106 & 0.1695 & 0.5981 & 0.0615 & 0.2460 & 0.1093 & 0.7599 & 0.9353 & 0.2378 & 0.3213 & 0.5391 \\
\hline A1 & $\mathrm{X}$ & $\mathrm{X}$ & $\mathrm{X}$ & $\mathrm{X}$ & $\mathrm{X}$ & $\mathrm{X}$ & $\mathrm{X}$ & $\mathrm{X}$ & $\mathrm{X}$ & $\mathrm{X}$ & $\mathrm{X}$ & $\mathrm{X}$ \\
\hline $\mathrm{A} 2$ & -0.7168 & 0.0214 & 0.1715 & -0.3746 & 0.2350 & 0.5372 & -0.4846 & 0.1639 & 0.4372 & -0.3372 & 0.1631 & 0.4372 \\
\hline A3 & $\mathrm{X}$ & $\mathrm{X}$ & $\mathrm{X}$ & $\mathrm{X}$ & $\mathrm{X}$ & $\mathrm{X}$ & $\mathrm{X}$ & $\mathrm{X}$ & $\mathrm{X}$ & $\mathrm{X}$ & $\mathrm{X}$ & $\mathrm{X}$ \\
\hline HS*A1 & $X$ & $\mathrm{X}$ & $\mathrm{X}$ & $X$ & $\mathrm{X}$ & $X$ & $\mathrm{X}$ & $\mathrm{X}$ & $\mathrm{X}$ & $\mathrm{X}$ & $\mathrm{X}$ & $\mathrm{X}$ \\
\hline HS*A2 & $X$ & $\mathrm{X}$ & $\mathrm{X}$ & $\mathrm{X}$ & $\mathrm{X}$ & $X$ & $\mathrm{X}$ & $\mathrm{X}$ & $\mathrm{X}$ & $\mathrm{X}$ & $\mathrm{X}$ & $\mathrm{X}$ \\
\hline HS*A3 & $X$ & $X$ & $X$ & $X$ & $X$ & $X$ & $X$ & $X$ & $X$ & $X$ & $X$ & $X$ \\
\hline
\end{tabular}




\section{Appendix 8 continued}

\begin{tabular}{|c|c|c|c|c|c|c|c|c|c|c|c|c|}
\hline \multicolumn{13}{|c|}{ Sparrows (Family Emberizidae) } \\
\hline & \multicolumn{12}{|c|}{ Year 1} \\
\hline & \multicolumn{3}{|c|}{ Winter } & \multicolumn{3}{|c|}{ Spring } & \multicolumn{3}{|c|}{ Summer } & \multicolumn{3}{|c|}{ Fall } \\
\hline & $\mathrm{PE}$ & $\mathrm{P}$-value & $\begin{array}{l}\text { FDR p- } \\
\text { value }\end{array}$ & $\mathrm{PE}$ & P-value & $\begin{array}{l}\text { FDR p- } \\
\text { value }\end{array}$ & $\mathrm{PE}$ & P-value & $\begin{array}{l}\text { FDR p- } \\
\text { value }\end{array}$ & $\mathrm{PE}$ & P-value & $\begin{array}{l}\text { FDR p- } \\
\text { value }\end{array}$ \\
\hline $\begin{array}{c}\% \\
\text { honey- } \\
\text { suckle } \\
\text { (HS) }\end{array}$ & 0.1081 & 0.6898 & 0.9406 & 0.0175 & 0.9338 & 0.9776 & 0.3972 & 0.0966 & 0.4831 & -0.2560 & 0.8721 & 0.9776 \\
\hline A1 & -0.1094 & 0.5759 & 0.8638 & 0.0053 & 0.9776 & 0.9776 & 0.3545 & 0.2469 & 0.6172 & 1.1799 & 0.3468 & 0.7432 \\
\hline A2 & $\mathrm{X}$ & $\mathrm{X}$ & $\mathrm{X}$ & $\mathrm{X}$ & $\mathrm{X}$ & $\mathrm{X}$ & $\mathrm{X}$ & $\mathrm{X}$ & $\mathrm{X}$ & $\mathrm{X}$ & $\mathrm{X}$ & $\mathrm{X}$ \\
\hline A3 & $\mathrm{X}$ & $\mathrm{X}$ & $\mathrm{X}$ & $\mathrm{X}$ & $X$ & $\mathrm{X}$ & $\mathrm{X}$ & $\mathrm{X}$ & $\mathrm{X}$ & $X$ & $\mathrm{X}$ & $\mathrm{X}$ \\
\hline HS*A1 & 0.7437 & 0.0074 & 0.0834 & -0.0362 & 0.8539 & 0.9776 & 0.1961 & 0.3987 & 0.7475 & 1.2645 & 0.4500 & 0.7500 \\
\hline HS*A2 & $\mathrm{X}$ & $X$ & $\mathrm{X}$ & $X$ & $\mathrm{X}$ & $X$ & $X$ & $\mathrm{X}$ & $X$ & $\mathrm{X}$ & $X$ & $\mathrm{X}$ \\
\hline HS*A3 & $X$ & $X$ & $X$ & $X$ & $X$ & $X$ & $X$ & $X$ & $X$ & $X$ & $X$ & $X$ \\
\hline
\end{tabular}




\section{Appendix 8 continued}

\begin{tabular}{|c|c|c|c|c|c|c|c|c|c|c|c|c|}
\hline \multicolumn{13}{|c|}{ Sparrows (Family Emberizidae) } \\
\hline & \multicolumn{12}{|c|}{ Year 2} \\
\hline & \multicolumn{3}{|c|}{ Winter } & \multicolumn{3}{|c|}{ Spring } & \multicolumn{3}{|c|}{ Summer } & \multicolumn{3}{|c|}{ Fall } \\
\hline & $\mathrm{PE}$ & P-value & $\begin{array}{c}\text { FDR p- } \\
\text { value }\end{array}$ & $\mathrm{PE}$ & P-value & $\begin{array}{l}\text { FDR p- } \\
\text { value }\end{array}$ & $\mathrm{PE}$ & P-value & $\begin{array}{c}\text { FDR p- } \\
\text { value }\end{array}$ & $\mathrm{PE}$ & P-value & $\begin{array}{c}\text { FDR p- } \\
\text { value }\end{array}$ \\
\hline $\begin{array}{c}\% \\
\text { honey- } \\
\text { suckle } \\
\text { (HS) }\end{array}$ & -0.3178 & 0.0000 & 0.0000 & 0.3806 & 0.0111 & 0.0834 & 0.0287 & 0.0086 & 0.0979 & 0.0686 & 0.2792 & 0.9445 \\
\hline A1 & 0.0000 & 0.0000 & 0.0000 & -0.1391 & 0.2229 & 0.6172 & 0.0970 & 0.7736 & 0.9445 & -0.4122 & 0.6545 & 0.9445 \\
\hline $\mathrm{A} 2$ & $\mathrm{X}$ & $\mathrm{X}$ & $\mathrm{X}$ & $\mathrm{X}$ & $\mathrm{X}$ & $\mathrm{X}$ & $\mathrm{X}$ & $\mathrm{X}$ & $\mathrm{X}$ & $\mathrm{X}$ & $\mathrm{X}$ & $\mathrm{X}$ \\
\hline A3 & $\mathrm{X}$ & $\mathrm{X}$ & $\mathrm{X}$ & $\mathrm{X}$ & $\mathrm{X}$ & $\mathrm{X}$ & $\mathrm{X}$ & $\mathrm{X}$ & $\mathrm{X}$ & $X$ & $X$ & $\mathrm{X}$ \\
\hline HS*A1 & 0.0000 & 0.0000 & 0.0000 & 0.1910 & 0.1302 & 0.4884 & 0.0411 & 0.0131 & 0.0979 & 0.0569 & 0.5150 & 0.9445 \\
\hline HS*A2 & $\mathrm{X}$ & $\mathrm{X}$ & $\mathrm{X}$ & $\mathrm{X}$ & $\mathrm{X}$ & $\mathrm{X}$ & $\mathrm{X}$ & $\mathrm{X}$ & $\mathrm{X}$ & $\mathrm{X}$ & $\mathrm{X}$ & $\mathrm{X}$ \\
\hline HS*A3 & $X$ & $X$ & $X$ & $X$ & $X$ & $X$ & $\mathrm{X}$ & $X$ & $X$ & $X$ & $X$ & $X$ \\
\hline
\end{tabular}




\section{Appendix 8 continued}

\begin{tabular}{|c|c|c|c|c|c|c|c|c|c|c|c|c|}
\hline \multicolumn{13}{|c|}{ Warblers (Family Parulidae) } \\
\hline & \multicolumn{12}{|c|}{ Year 1} \\
\hline & \multicolumn{3}{|c|}{ Winter } & \multicolumn{3}{|c|}{ Spring } & \multicolumn{3}{|c|}{ Summer } & \multicolumn{3}{|c|}{ Fall } \\
\hline & $\mathrm{PE}$ & P-value & $\begin{array}{c}\text { FDR p- } \\
\text { value }\end{array}$ & $\mathrm{PE}$ & P-value & $\begin{array}{l}\text { FDR p- } \\
\text { value }\end{array}$ & $\mathrm{PE}$ & $\mathrm{P}$-value & $\begin{array}{c}\text { FDR p- } \\
\text { value }\end{array}$ & $\mathrm{PE}$ & P-value & $\begin{array}{c}\text { FDR p- } \\
\text { value }\end{array}$ \\
\hline $\begin{array}{c}\% \\
\text { honey- } \\
\text { suckle } \\
\text { (HS) }\end{array}$ & $\mathrm{X}$ & $\mathrm{X}$ & $X$ & $X$ & $\mathrm{X}$ & $\mathrm{X}$ & $\mathrm{X}$ & $\mathrm{X}$ & $\mathrm{X}$ & $\mathrm{X}$ & $\mathrm{X}$ & $\mathrm{X}$ \\
\hline A1 & 0.7079 & 0.1918 & 0.3069 & 1.0390 & 0.0026 & 0.0113 & - & - & - & - & - & - \\
\hline $\mathrm{A} 2$ & $\mathrm{X}$ & $\mathrm{X}$ & $\mathrm{X}$ & $\mathrm{X}$ & $\mathrm{X}$ & $\mathrm{X}$ & $\mathrm{X}$ & $\mathrm{X}$ & $\mathrm{X}$ & $\mathrm{X}$ & $\mathrm{X}$ & $\mathrm{X}$ \\
\hline A3 & 2.6773 & 0.1396 & 0.2792 & 0.5983 & 0.0028 & 0.0113 & - & - & - & - & - & - \\
\hline HS*A1 & $\mathrm{X}$ & $\mathrm{X}$ & $\mathrm{X}$ & $\mathrm{X}$ & $\mathrm{X}$ & $\mathrm{X}$ & $\mathrm{X}$ & $\mathrm{X}$ & $\mathrm{X}$ & $\mathrm{X}$ & $\mathrm{X}$ & $\mathrm{X}$ \\
\hline HS*A2 & $\mathrm{X}$ & $X$ & $X$ & $\mathrm{X}$ & $\mathrm{X}$ & $\mathrm{X}$ & $\mathrm{X}$ & $\mathrm{X}$ & $\mathrm{X}$ & $\mathrm{X}$ & $\mathrm{X}$ & $\mathrm{X}$ \\
\hline HS*A3 & $X$ & $X$ & $X$ & $X$ & $X$ & $X$ & $\mathrm{X}$ & $X$ & $X$ & $X$ & $X$ & $X$ \\
\hline
\end{tabular}




\section{Appendix 8 continued}

\begin{tabular}{|c|c|c|c|c|c|c|c|c|c|c|c|c|}
\hline \multicolumn{13}{|c|}{ Warblers (Family Parulidae) } \\
\hline & \multicolumn{12}{|c|}{ Year 2} \\
\hline & \multicolumn{3}{|c|}{ Winter } & \multicolumn{3}{|c|}{ Spring } & \multicolumn{3}{|c|}{ Summer } & \multicolumn{3}{|c|}{ Fall } \\
\hline & $\mathrm{PE}$ & P-value & $\begin{array}{l}\text { FDR p- } \\
\text { value }\end{array}$ & $\mathrm{PE}$ & P-value & $\begin{array}{l}\text { FDR p- } \\
\text { value }\end{array}$ & $\mathrm{PE}$ & P-value & $\begin{array}{l}\text { FDR p- } \\
\text { value }\end{array}$ & $\mathrm{PE}$ & P-value & $\begin{array}{l}\text { FDR p- } \\
\text { value }\end{array}$ \\
\hline $\begin{array}{c}\% \\
\text { honey- } \\
\text { suckle } \\
(\mathrm{HS})\end{array}$ & $\mathrm{X}$ & $\mathrm{X}$ & $\mathrm{X}$ & $\mathrm{X}$ & $\mathrm{X}$ & $\mathrm{X}$ & $\mathrm{X}$ & $X$ & $X$ & $\mathrm{X}$ & $\mathrm{X}$ & $\mathrm{X}$ \\
\hline A1 & - & - & - & -0.0939 & 0.7305 & 0.9739 & - & - & - & 0.0000 & 1.0000 & 1.0000 \\
\hline $\mathrm{A} 2$ & $\mathrm{X}$ & $\mathrm{X}$ & $\mathrm{X}$ & $\mathrm{X}$ & $\mathrm{X}$ & $\mathrm{X}$ & $\mathrm{X}$ & $\mathrm{X}$ & $\mathrm{X}$ & $\mathrm{X}$ & $\mathrm{X}$ & $\mathrm{X}$ \\
\hline A3 & - & - & - & 0.5124 & 0.0926 & 0.2468 & - & - & - & 0.0000 & 1.0000 & 1.0000 \\
\hline HS*A1 & $\mathrm{X}$ & $\mathrm{X}$ & $\mathrm{X}$ & $\mathrm{X}$ & $\mathrm{X}$ & $\mathrm{X}$ & $X$ & $\mathrm{X}$ & $X$ & $\mathrm{X}$ & $\mathrm{X}$ & $\mathrm{X}$ \\
\hline HS*A2 & $X$ & $X$ & $\mathrm{X}$ & $X$ & $\mathrm{X}$ & $X$ & $X$ & $\mathrm{X}$ & $X$ & $X$ & $X$ & $X$ \\
\hline HS*A3 & $X$ & $X$ & $X$ & $X$ & $X$ & $X$ & $X$ & $X$ & $X$ & $X$ & $X$ & $X$ \\
\hline
\end{tabular}




\section{Appendix 9}

Effect of honeysuckle density on bird counts, species richness (S), bird diversity (Shannon $\mathrm{N}_{1}, \mathrm{~N}_{1}=\mathrm{e}^{\mathrm{H}}$ ), and bird evenness (Shannon measure of evenness, $\mathrm{E}_{\mathrm{H}}, \mathrm{E}_{\mathrm{H}}=[-\Sigma p i$ $\ln p i] / \ln \mathrm{S}$ ) for all 13 forest stands in each season with years combined.

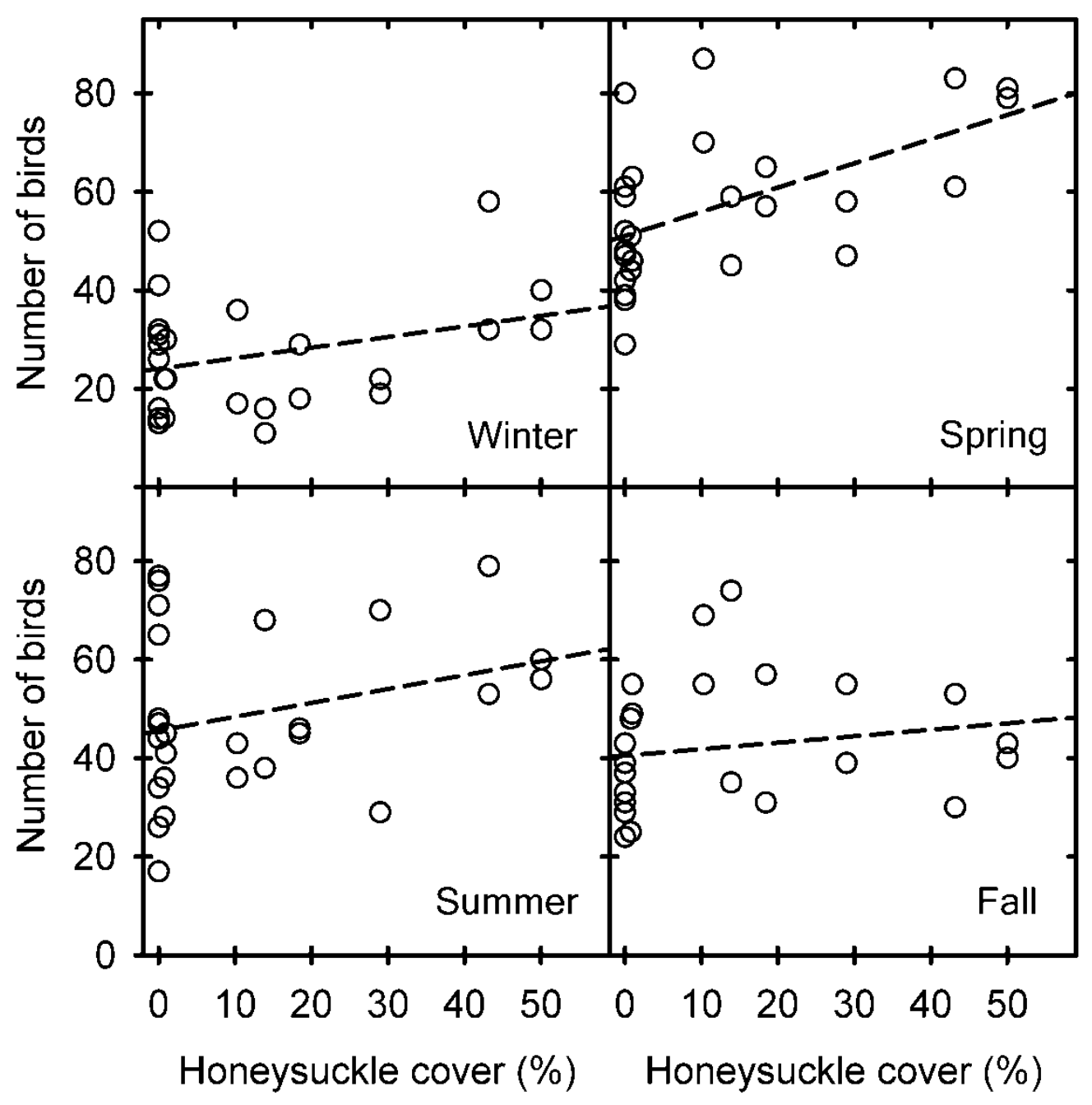


Appendix 9 continued

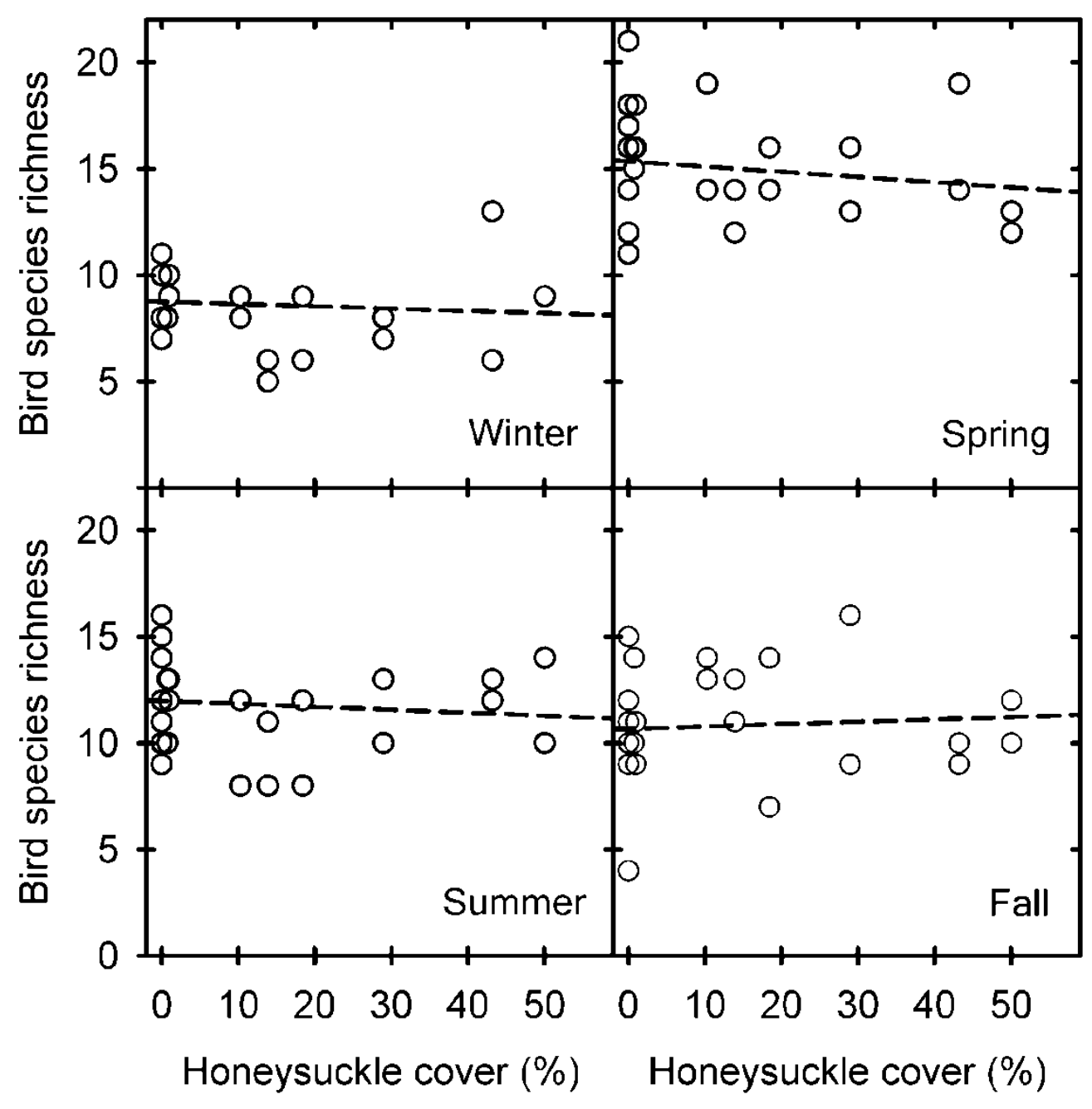


Appendix 9 continued

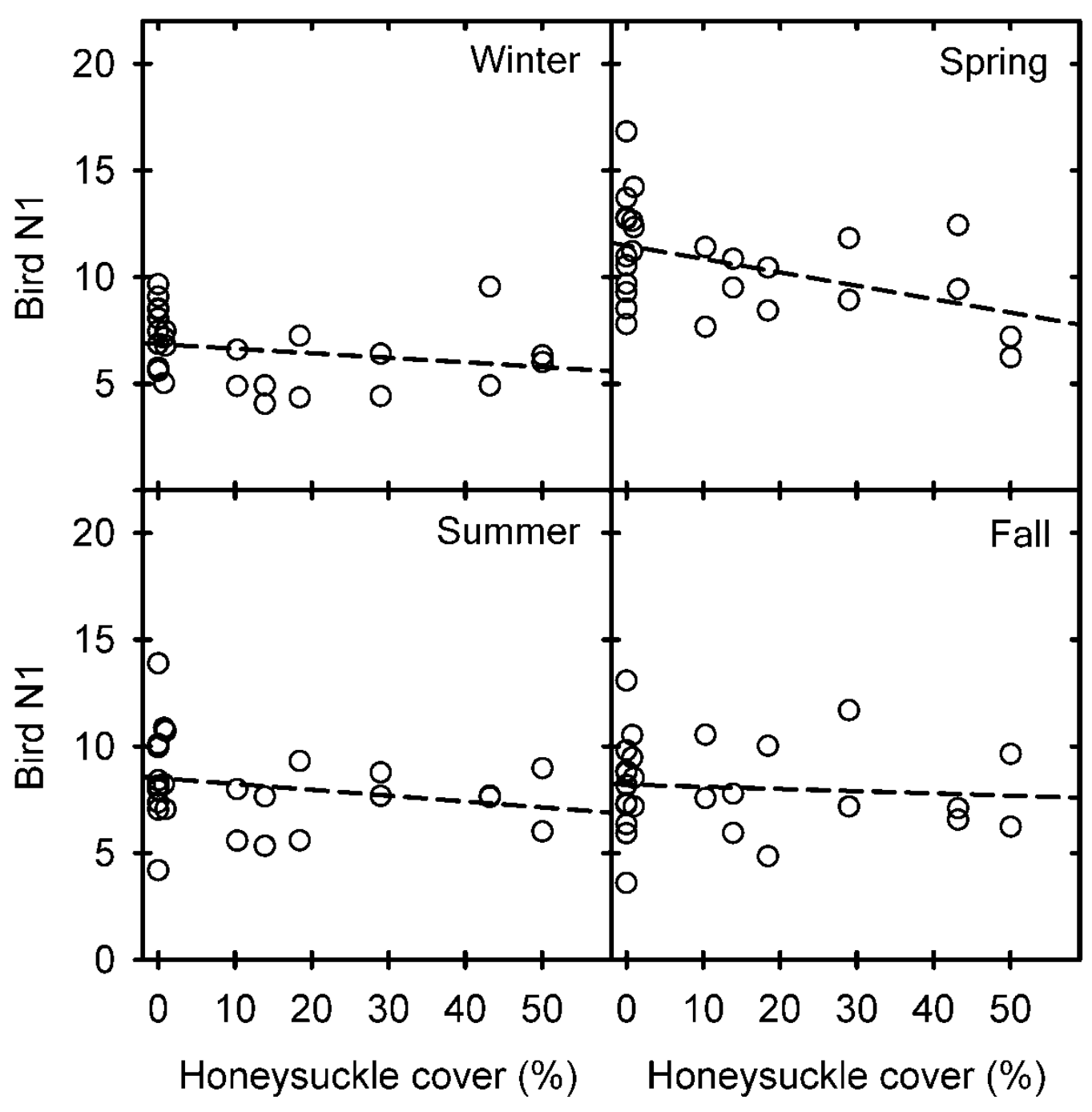


Appendix 9 continued

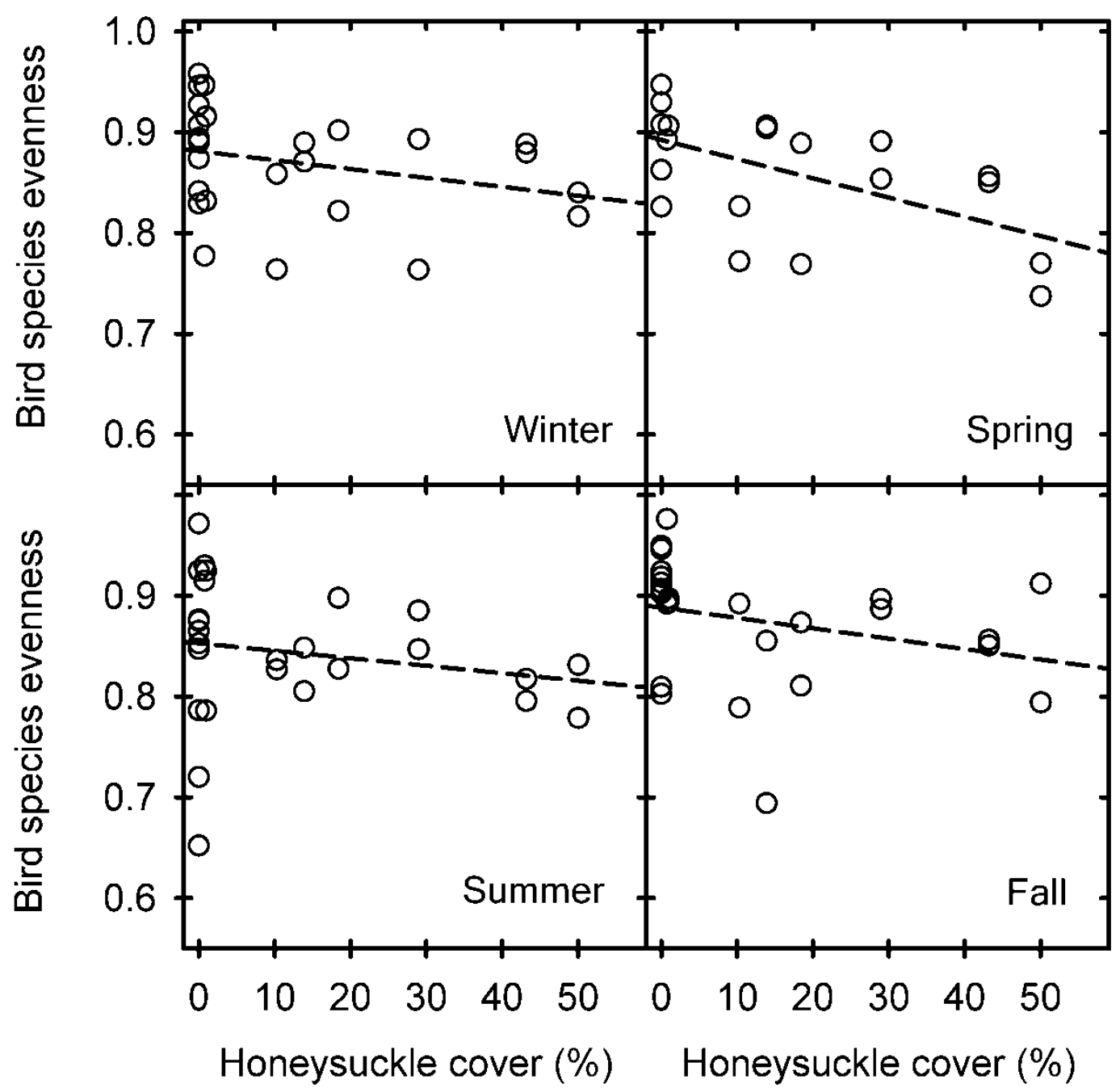




\section{Appendix 10}

List of all bird species and the frequency observed throughout the study (Pyle and DeSante 2014).

\begin{tabular}{|l|l|r|}
\hline Bird species & Code & Frequency \\
\hline Acadian Flycatcher & ACFL & 2 \\
\hline American Crow & AMCR & 32 \\
\hline American Goldfinch & AMGO & 2 \\
\hline American Robin & AMRO & 585 \\
\hline American Tree Sparrow & ATSP & 2 \\
\hline Baltimore Oriole & BAOR & 1 \\
\hline Black-and-white Warbler & BAWW & 1 \\
\hline Blackburnian Warbler & BLBW & 1 \\
\hline Barred Owl & BADO & 1 \\
\hline Blackpoll Warbler & BLPW & 4 \\
\hline Black-throated Green Warbler & BTNW & 13 \\
\hline Blue-gray Gnatcatcher & BGGN & 83 \\
\hline Blue Jay & BLJA & 179 \\
\hline Brown Creeper & BRCR & 25 \\
\hline Brown-headed Cowbird & BHCO & 57 \\
\hline Brown Thrasher & BRTH & 1 \\
\hline Carolina Chickadee & CACH & 460 \\
\hline Carolina Wren & CARW & 318 \\
\hline Cedar Waxwing & CEDW & 7 \\
\hline Chipping Sparrow & CHSP & 46 \\
\hline Dark-eyed Junco & DEJU & 11 \\
\hline Downy Woodpecker & DOWO & 154 \\
\hline Eastern Bluebird & EABL & 6 \\
\hline Eastern Phoebe & EAPH & 5 \\
\hline Eastern Towhee & EATO & 215 \\
\hline Eastern Wood-Pewee & EAWP & 60 \\
\hline European Starling & EUST & 4 \\
\hline Field Sparrow & GISP & 38 \\
\hline Golden-crowned Kinglet & GRCI & 11 \\
\hline Gray Catbird & & 10 \\
\hline Great Crested Flycatcher & GCF & 13 \\
\hline
\end{tabular}




\section{Appendix 10 continued}

\begin{tabular}{|l|l|r|}
\hline Hairy Woodpecker & HAWO & 28 \\
\hline Hermit Thrush & HETH & 15 \\
\hline House Finch & HOFI & 20 \\
\hline House Wren & HOWR & 2 \\
\hline House Sparrow & HOSP & 4 \\
\hline Indigo Bunting & INBU & 13 \\
\hline Kentucky Warbler & KEWA & 3 \\
\hline Mourning Dove & MODO & 33 \\
\hline Nashville Warbler & NAWA & 3 \\
\hline Northern Bobwhite & NOBO & 1 \\
\hline Northern Cardinal & NOCA & 985 \\
\hline Northern Flicker & NOFL & 11 \\
\hline Northern Mockingbird & NOMO & 1 \\
\hline Olive-sided Flycatcher & OSFL & 1 \\
\hline Palm Warbler & PAWA & 3 \\
\hline Philadelphia Vireo & PHVI & 2 \\
\hline Pileated Woodpecker & PIWO & 23 \\
\hline Pine Warbler & PIWA & 21 \\
\hline Red-bellied Woodpecker & RBWO & 180 \\
\hline Red-eyed Vireo & REVI & 56 \\
\hline Red-shouldered Hawk & RSHA & 2 \\
\hline Red-tailed Hawk & RTHA & 3 \\
\hline Red-winged Blackbird & RWBL & 4 \\
\hline Rose-breasted Grosbeak & RBGR & 1 \\
\hline Ruby-crowned Kinglet & RCKI & 3 \\
\hline Scarlet Tanager & SCTA & 2 \\
\hline Song Sparrow & SOSP & 26 \\
\hline Summer Tanager & SUTA & 4 \\
\hline Swainson's Thrush & SWTH & 25 \\
\hline Swamp Sparrow & SWSP & 15 \\
\hline Tufted Titmouse & TUTI & 438 \\
\hline Turkey Vulture & TUVU & 4 \\
\hline & & \\
\hline
\end{tabular}


Appendix 10 continued

\begin{tabular}{|l|l|r|}
\hline Veery & VEER & 1 \\
\hline Warbling Vireo & WAVI & 4 \\
\hline White-breasted Nuthatch & WBNU & 130 \\
\hline White-eyed Vireo & WEVI & 6 \\
\hline White-throated Sparrow & WTSP & 32 \\
\hline Willow Flycatcher & WIFL & 5 \\
\hline Wood Thrush & WOTH & 62 \\
\hline Worm-eating Warbler & WEWA & 2 \\
\hline Yellow-bellied Sapsucker & YBSA & 8 \\
\hline Yellow-billed Cuckoo & YBCU & 3 \\
\hline Yellow-rumped Warbler & YRWA & 29 \\
\hline Yellow-throated Vireo & YTVI & 11 \\
\hline Yellow Warbler & YEWA & 4 \\
\hline
\end{tabular}




\section{CURRICULUM VITA}

NAME: $\quad$ Katie Rae Lynch

ADDRESS: 1829 South $3^{\text {rd }}$ St.

Apartment 4

Louisville, KY 40208

(502) 432-4083

katie.1ynch@louisville.edu

DOB: $\quad$ Louisville, Kentucky - August 23, 1986

EDUCATION: $\quad$ University of Louisville (Louisville, KY): Ph. D., 2016

Department of Biology

University of Louisville (Louisville, KY): M. S., 2016

Department of Biology

University of Kentucky (Lexington, KY): B. S., 2008

Department of Animal and Food Science (major)

Department of Biology (minor)

TEACHING: $\quad$ University of Louisville (Louisville, KY): Teaching Assistant

Human Anatomy and Physiology Lab: 2014-2016

Principles of Biology Lab (for science majors): 2013-2014

Introductory Biological Systems (for non-science majors):

2012

University of Louisville (Louisville, KY): Guest Lecturer

Introductory Biology I for majors - Unity of Life: 2012

Introductory Biology II for majors - Diversity of Life:

2014, 2015

University of Louisville, Resources for Academic Achievement:

Supplemental Instructor

Introductory Biology II for majors - Diversity of Life:

2011

Introductory Biology I for majors - Unity of Life: 2012

University of Kentucky (Lexington, KY): Undergraduate

Teaching Assistant

Special Problems in Animal Science/Food Science: 2007 
GRANTS: $\quad$ University of Louisville Horner Preserve Fund (2013)

Graduate Student Union Grant, University of Louisville (2013)

Travel Grant, Graduate Student Council, University of Louisville (2013)

\section{PRESENTATIONS:}

- Lynch, K.R., J.E. Alexander. 2015. Effects of Lonicera spp. on bird diversity in forested areas of the Louisville Metropolitan area. Midwest Ecology and Evolution Conference (Bloomington, Indiana).

- Lynch, K.R., J.E. Alexander. 2014. Effects of Lonicera spp. on bird diversity in forested areas of the Louisville Metropolitan area. Kentucky Academy of Sciences (Lexington, Kentucky).

- Lynch, K.R. 2013. Effects of Lonicera spp. on bird diversity in forested areas of the Louisville Metropolitan area. University of Kentucky Conference of Ecology, Evolution, and Behavioral Biology (Lexington, Kentucky).

- Lynch, K.R. 2012. Effects of honeysuckle removal on bird diversity in two Louisville, KY metropolitan parks. University of Louisville Graduate Symposium (Louisville, Kentucky).

\section{UNIVERSITY AND PROFESSIONAL SERVICE:}

Member of Biology Graduate Student Association, U. of Louisville (2010 - 2016)

Secretary of Biology Graduate Student Association (2014 - 2015)

Judge of undergraduate poster competition at Kentucky Academy of Sciences conference (2014)

Fundraising Chair of the Biology Graduate Student Association $(2013-2014)$

Adopt-A-Highway - Biology Graduate Student Association (2010 -2012 )

Volunteer for Olmsted Parks Conservancy (2012)

\section{PROFESSIONAL DEVELOPMENT:}

Selected for and attended the Graduate Teaching Assistant

Academy, School of Interdisciplinary and Graduate Studies, U. of Louisville (2012 - 2013)

Attended Invasive Species Symposium in Columbus, OH (2013) 